UNIVERSIDADE DE SÃO PAULO

FACULDADE DE ECONOMIA, ADMINISTRAÇÃO E CONTABILIDADE DEPARTAMENTO DE ADMINISTRAÇÃO PROGRAMA DE PÓS-GRADUAÇ̃̃o EM ADMINISTRAÇÃo

POSICIONAMENTO DE MARCAS DE SERVIÇOS

NO CONTEXTO DA INOVAÇÃO DISRUPTIVA:

UM ESTUDO DE CASO NO SETOR DE TELECOMUNICAÇÕES.

Bruno Antunes Oliveira

Orientadora: Profa. Dra. Ana Akemi Ikeda

SÃO PAULO 
Prof. Dr. João Grandino Rodas

Reitor da Universidade de São Paulo

Prof. Dr. Reinaldo Guerreiro

Diretor da Faculdade de Economia, Administração e Contabilidade

Prof. Dr. Adalberto Américo Fischmann

Chefe do Departamento de Administração

Prof. Dr. Lindolfo Galvão de Albuquerque Coordenador do Programa de Pós-Graduação em Administração 


\title{
POSICIONAMENTO DE MARCAS DE SERVIÇOS \\ NO CONTEXTO DA INOVAÇÃO DISRUPTIVA: \\ UM ESTUDO DE CASO NO SETOR DE TELECOMUNICAÇÕES.
}

\begin{abstract}
Dissertação apresentada ao Departamento de Administração da Faculdade de Economia, Administração e Contabilidade da Universidade de São Paulo, como requisito para obtenção do título de Mestre em Ciências.
\end{abstract}

Orientadora: Profa. Dra. Ana Akemi Ikeda

Versão Corrigida

(versão original disponível na Faculdade de Economia, Administração e Contabilidade)

\section{SÃO PAULO}


Dissertação defendida em 23/08/2013 na FEA-USP

e aprovada pela banca composta pelos professores:

Prof $^{\mathrm{a}}$ Dr $^{\mathrm{a}}$ Ana Akemi Ikeda

Prof $^{\mathrm{a}}$ Dr $^{\mathrm{a}}$ Maria do Carmo Romeiro

Prof. Dr. Aléssio Bessa Sarquis

FICHA CATALOGRÁFICA

Elaborada pela seção de Processamento Técnico do SBD/FEA/USP

Oliveira, Bruno Antunes

Posicionamento de marcas de serviços no contexto da inovação disruptiva: um estudo de caso no setor de telecomunicações / Bruno Antunes Oliveira. - São Paulo, 2013.

$176 \mathrm{p}$.

Dissertação (Mestrado) - Universidade de São Paulo, 2013.

Orientador: Ana Akemi Ikeda.

1. Inovações tecnológicas - Administração 2. Posicionamento 3.

Serviços 4. Telecomunicações I. Universidade de São Paulo. Faculdade de Economia, Administração e Contabilidade. II. Título.

CDD - 658.514 
A meus pais, Rui e Solange. 
Gostaria de agradecer primeiramente à Prof ${ }^{\mathrm{a}}$. Dr $^{\mathrm{a}}$ Ana Akemi Ikeda pela oportunidade que me foi concedida e poder, mais uma vez, além da graduação, evoluir academicamente com a realização do curso de mestrado na FEA-USP. Agradeço também por todo o apoio, incentivo e orientação durante todo o período, que foram essenciais para a conclusão deste trabalho.

Agradeço também aos professores com os quais pude contar durante a realização do curso, com interações proveitosas e conteúdos de aula pertinentes, que muito contribuíram para o desenvolvimento deste trabalho; em especial aos professores doutores Silvio Santos, Marcos Campomar, Geraldo Toledo, Evandro Lopes e Suzane Strehlau. E aos professores doutores Aléssio Bessa e Maria do Carmo Romeiro, cujas contribuições no exame de qualificação foram de enorme valor para o devido encaminhamento do trabalho.

Aos colegas do programa de mestrado, com os quais pude compartilhar expectativas, dúvidas e o espírito de amizade e ajuda mútua.

Agradeço também imensamente pela disponibilidade, boa vontade e contribuição mais que valiosa dos profissionais entrevistados: Daniel Cardoso, Giseli Passarini, Hugo Janeba, Joyce Paiva, Leonardo Contrucci e Silvio Sato, sem a participação dos quais a realização desse trabalho não teria sido possível. Agradeço especialmente ao Hugo e ao Silvio, pelo exemplo e pelo importante papel em minha formação profissional.

Obrigado também a toda a equipe com a qual tenho o maior prazer de conviver diariamente e foram fundamentais na criação das condições para que minha participação no programa de mestrado fosse possível, em especial à Carol Sierra e à Cris Duclos.

Aos meus familiares e amigos, agradeço pelo suporte e apoio incondicional em todos os momentos, me incentivando para a conclusão desta jornada. 
"All unsere Wissenschaft ist, gemessen an der Wirklichkeit, primitiv und kindlich - und doch ist sie unser kostbarstes Gut.”

Albert Einstein

"Toda a nossa ciência é, comparada com a realidade, primitiva e inocente - e, no entanto, é a coisa mais preciosa que temos." 


\section{RESUMO}

Este trabalho enfoca o campo de atuação do marketing de serviços, setor cada vez mais representativo nas economias mundiais, em que a competitividade igualmente crescente demanda das empresas a capacidade de inovar e se diferenciar continuamente em prol da sobrevivência e crescimento. As características distintivas de marcas de serviços, sobretudo o caráter intangível da prestação, trazem para estas empresas o desafio da transformação dos serviços em benefícios concretos, buscando um posicionamento sólido junto aos consumidores e influenciando o processo de decisão de compra.

Assim, é objetivo deste trabalho estudar como o posicionamento de marcas de serviços é gerido quando ocorre a introdução de uma inovação disruptiva, ou seja, quando a empresa decide pela introdução de uma tecnologia de ruptura, com uma proposição de valor consideravelmente diferente da tecnologia vigente.

A metodologia adotada envolveu primeiramente a revisão de literatura nos temas de marketing de serviços, segmentação/posicionamento e aspectos da inovação disruptiva, buscando um entendimento da relação entre os construtos. De forma complementar, considerando-se a adequação com a questão de pesquisa, decidiu-se pela condução de um estudo de caso enfocando uma empresa do setor de serviços de telecomunicação móvel brasileiro, a Vivo S/A. A decisão pelo estudo de caso único foi motivada pelo caráter peculiar da situação estudada, representada pela introdução da tecnologia GSM pela empresa no período compreendido entre os anos 2006 e 2007, em caráter disruptivo. Estudou-se a forma como a empresa procedeu no tocante aos processos de segmentação, posicionamento e gestão do composto de marketing frente a este evento.

Os resultados apontam para uma influência significativa da mudança tecnológica no posicionamento da marca, com maior impacto nos fatores relacionados a produto, promoção e pessoas, do composto de marketing de serviços. A pesquisa também revelou o poder de tecnologias emergentes em transformar as competências internas de uma empresa, muito além da tecnologia em si. Por fim, os resultados mostram como a empresa conseguiu resultados positivos nas dimensões de negócios e de marca, revertendo uma situação competitiva desfavorável, identificada no contexto que se pôde construir para o caso.

Palavras-chave: marketing de serviços; inovação disruptiva; posicionamento; marcas; composto de marketing; telecomunicações. 


\begin{abstract}
The following dissertation will address the theme of services marketing, a sector that has been increasingly representative in global economies, where competitiveness is constantly growing and demands that companies have the ability to continually innovate and differentiate in favor of their own survival and growth. The distinctive characteristics of service brands, especially the intangible characteristic, bring to these companies the challenge of transforming services into concrete benefits, seeking a solid position among consumers and influencing the purchase decision process.

Thus, the objective of this project is to study how the positioning of services brands are managed when there's introduction of a disruptive innovation, ie, when the company decides to introduce a disruptive technology, with a value proposition considerably different from the current technology.

The adopted methodology involved primarily a literature review in the areas of services marketing, segmentation / positioning and aspects of disruptive innovation, seeking to understand the relationship between the concepts. In a complementary way, considering the suitability to the research question, it was decided to conduct a case study focused on a mobile telecommunications company in Brazil, Vivo S/A. The decision for a single case study was motivated by the peculiar character of the studied situation, represented by the introduction of GSM technology by the company in the period between 2006 and 2007 in a disruptive character. The project sought to understand how the company proceeded regarding the processes of segmentation, positioning and management of the marketing mix, considering this event.

The results point to a significant influence of technological change in brand positioning, with the greatest impact on factors related to product, promotion and people of the services marketing mix. The research also revealed the power of emerging technologies to transform the internal competencies of a company, beyond the technology itself. Finally, the results show how the company achieved positive results in the dimensions of business and brand, reversing a competitive disadvantage, identified in the context that could build into the case.
\end{abstract}

Keywords: services marketing; disruptive innovation; positioning; brands; marketing mix; telecommunications. 



\section{SUMÁRIO}

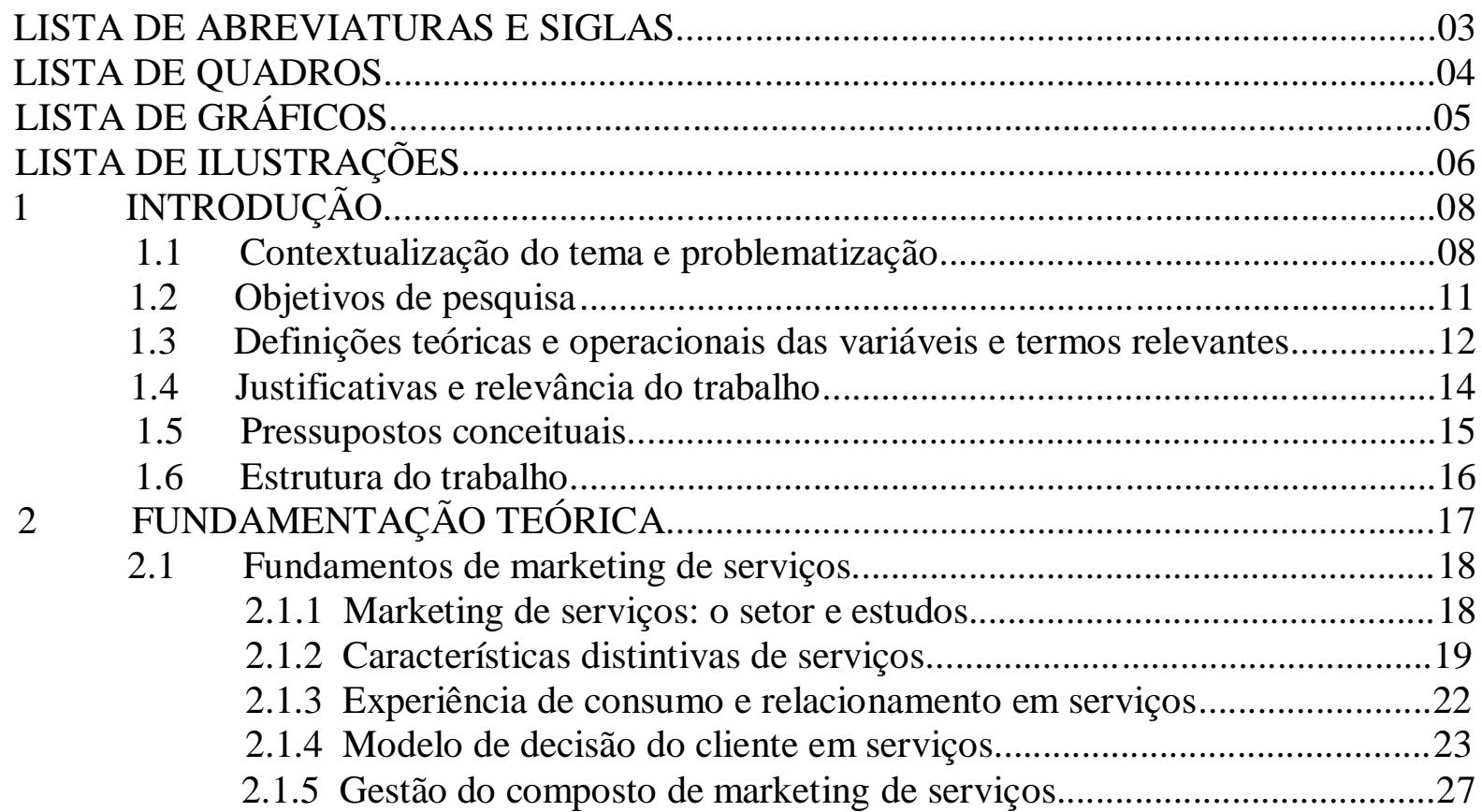

2.2 Segmentação de mercado, gestão de marcas e posicionamento de marcas........30

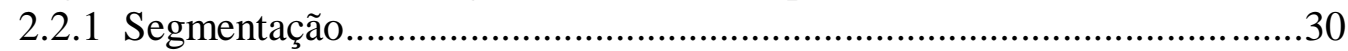

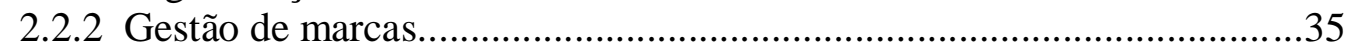

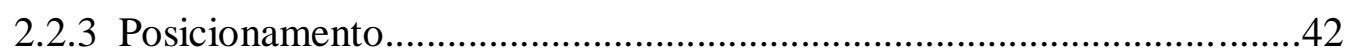

2.2.4 Segmentação e posicionamento no âmbito do processo de marketing....49

2.3 Introdução de inovações disruptivas..............................................................52

2.3.1 Conceituação de inovações disrputivas............................................52

2.3.2 Tecnologias de conexão móvel..........................................................57

2.4 Setor de serviços de telecomunicações no Brasil..............................................59

2.4.1 Áreas de atuação e bandas de freqüência das operadoras celulares......62

2.4.2 Evolução do setor de telecomunicações brasileiro...............................65

2.4.3 Evolução dos acessos celulares por tecnologia no Brasil.....................68

2.5 Modelo conceitual teórico da pesquisa............................................................69

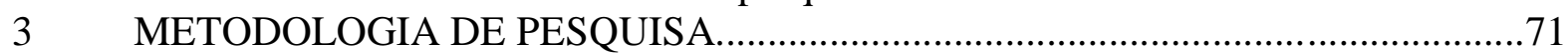

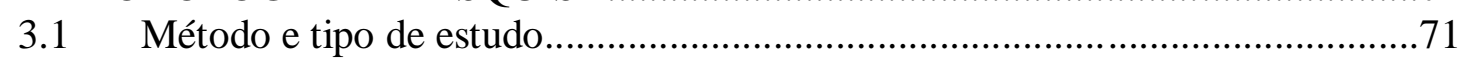

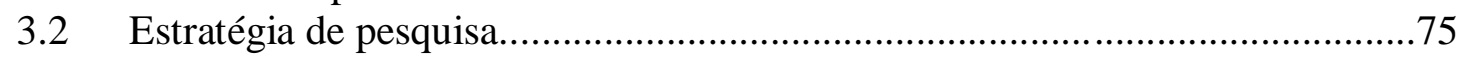

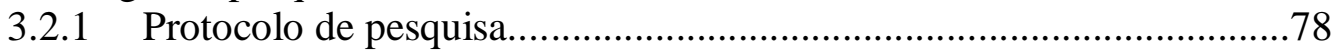

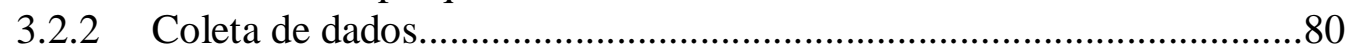

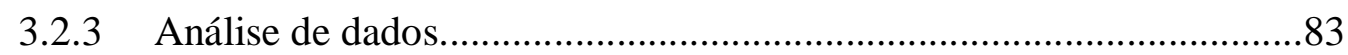

4 APRESENTAÇÃO DE RESULTADOS: O CASO VIVO.......................................86

4.1 Apresentação da empresa: breve contexto de formação da Vivo S/A...............86

4.2 Breve histórico de marca e posicionamento....................................................90

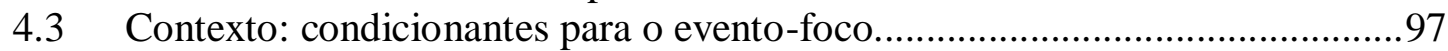

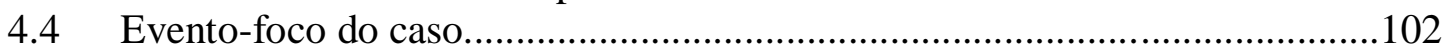

4.4.1 Mudança de tecnologias: do CDMA para o GSM.............................102

4.4.2 Mudança de estratégia: foco na prestação de serviços........................106

4.4.3 Mudança de posicionamento: Vivo. Sinal de qualidade.....................108

4.5 Impactos no composto de marketing de serviços..........................................117

4.5.1 "Produto": serviços e aparelhos.......................................................... 118 
4.5.2 "Preço": planos, recargas, promoções................................................122

4.5.3 "Promoção": comunicação e vendas................................................123

4.5.4 "Praça": distribuição e logística........................................................131

4.5.5 "Physical surroundings": instalações..............................................133

4.5.6 "Processos": atendimento e sistemas................................................ 134

4.5.7 "Pessoas": colaboradores e atendentes em geral...............................135

4.6 Resultados de negócios e de marca.............................................................137

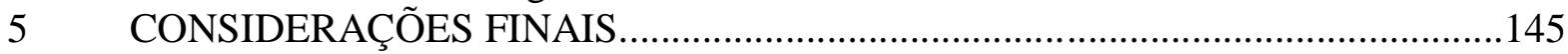

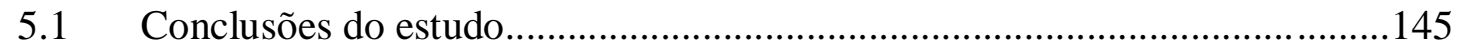

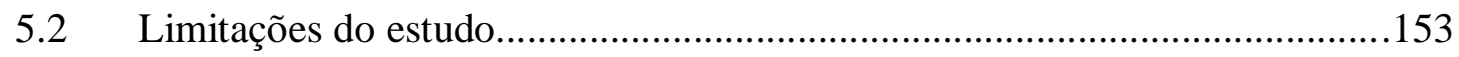

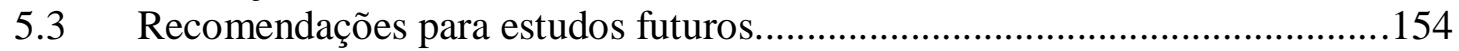

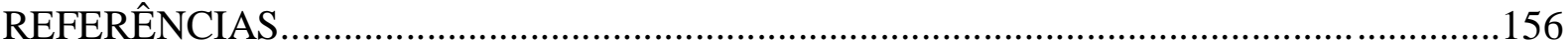

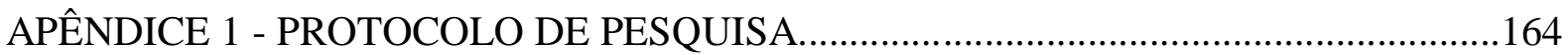

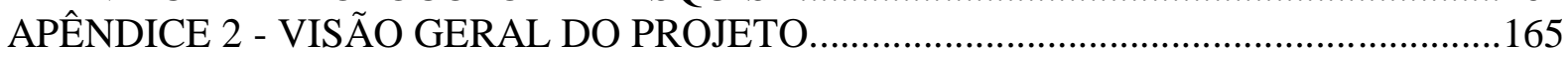

APÊNDICE 3 - ROTEIRO DE ENTREVISTA EM PROFUNDIDADE ..............................168

ANEXO 1 - DISCURSOS INTERNOS DA PRESIDÊNCIA...........................................173 


\section{LISTA DE ABREVIATURAS E SIGLAS}

2G: Segunda geração das tecnologias de comunicação móvel

3G: Terceira geração das tecnologias de comunicação móvel

4 P's: Os quatro fatores que compõem o mix de marketing - produto, preço, promoção e praça 4G: Quarta geração das tecnologias de comunicação móvel

7 P's: Os sete fatores que compõem o mix de marketing de serviços - produto, preço, promoção, praça, processos, pessoas e physical surroundings (instalações)

ADVB: Associação dos Dirigentes de Vendas e Marketing do Brasil

AMA: American Marketing Association

AMPS: Advanced Mobile Phone System, tecnologia de comunicação móvel de $1^{a}$ geração

ANATEL: Agência Nacional das Telecomunicações

ARPU: Average revenue per user, a receita média por usuário, por mês

BNDES: Banco Nacional de Desenvolvimento Econômico e Social

BSC: Balanced Scorecard

CCC: Central de Comutação e Controle

CDMA: Code Division Multiple Access, tecnologia de comunicação móvel 2G

CDMA 1xEVDO: CDMA Evolution-Data Optimized, tecnologia de comunicação móvel 3G

CDMA 1xRTT: CDMA Radio Transmission Technology, tecnologia de comunicação móvel 2G

CHURN: Indicador da rotatividade dos usuários dos serviços de uma empresa

Dir.: Abreviatura de Diretoria

DSL: Digital Subscriber Line, tecnologia de transmissão digital de dados por telefonia fixa

DVD: Digital Versatile Disc, disco de armazenamento digital

EBITDA: Resultado operacional antes de juros, impostos, depreciação e amortização

EDGE: Enhanced Date Rates For GSM Evolution, tecnologia de comunicação móvel 2G

ERB: Estação Rádio-Base

GPRS: General Packet Radio Service, tecnologia de comunicação móvel 2G

GPS: Global Positioning System, sistema de navegação por satélite

GSM: Global System for Mobile Communication, tecnologia de comunicação móvel 2G

HSPA: High Speed Packet Access, tecnologia de comunicação móvel 3G

Kbps: Quilobit por segundo, unidade de transmissão de dados

LGT: Lei Geral das Telecomunicações

LTE: Long Term Evolution, tecnologia de comunicação móvel 4G

Margem EBITDA: EBITDA dividido pela Receita Operacional Líquida

Mbps: Megabit por segundo, unidade de transmissão de dados

MHz: Megahertz, unidade de freqüência de ondas

MP3: Formato de compressão de áudio

PIB: Produto Interno Bruto

PMO: Project Management Office

SERVQUAL: Modelo para medição da qualidade em serviços

SMS: Short Message Service, serviço de mensagens instantâneas da telefonia celular

TDMA: Time Division Multiple Acess, tecnologia de comunicação móvel 2G

TI: Tecnologia da Informação

USP: Unique Selling Proposition

VHS: Video Home System, sistema doméstico de gravação de áudio e vídeo

WCDMA: Wide-Band Code-Division Multiple Access, tecnologia de comunicação móvel 3G 


\section{LISTA DE QUADROS}

Quadro 01 - Escores médios que definem o grau de competitividade...................................10

Quadro 02 - Blocos temáticos da fundamentação teórica........................................................17

Quadro 03 - Relação entre fatores condicionantes e estratégias de segmentação.....................31

Quadro 04 - Características básicas do cliente......................................................................33

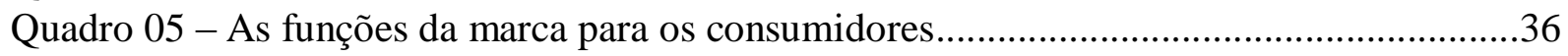

Quadro 06 - Abstrações de conceitos relacionados à marca..................................................37

Quadro 07 - Possibilidades de estratégias de posicionamento ...............................................48

Quadro 08 - Gerações de sistemas celulares e respectivas tecnologias...................................57

Quadro 09 - Tecnologias celulares de segunda geração: TDMA, CDMA e GSM..................58

Quadro 10 - Relação de operadoras celulares por banda de frequência e área de serviço.......64

Quadro 11 - Características dos dois principais paradigmas..................................................71

Quadro 12 - Diferenças entre os enfoques quantitativo e qualitativo.....................................72

Quadro 13 - Comparação entre concepções básicas de pesquisa.............................................73

Quadro 14 - Situações relevantes para diferentes métodos de pesquisa.................................74

Quadro 15 - Táticas de estudo de caso para quatro testes de projeto......................................79

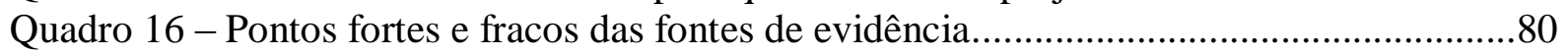

Quadro 17 - Principais métodos de análise de dados qualitativos............................................84

Quadro 18 - Evolução do posicionamento de marca e tecnologias Vivo................................95

Quadro 19 - Pilares do novo posicionamento proposto....................................................113

Quadro 20 - Quatro diretrizes para o novo posicionamento..............................................114

Quadro 21 - Diretriz "melhor no que importa"...................................................................114

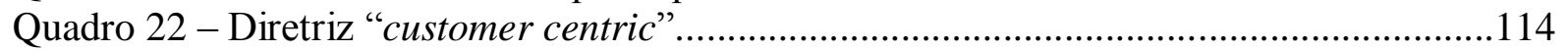

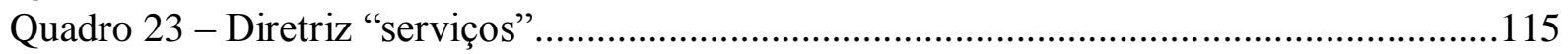

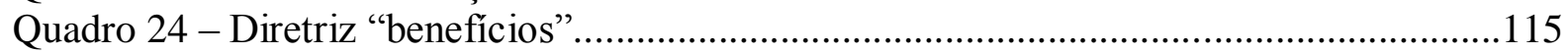

Quadro 25 - Níveis de impacto no composto de marketing Vivo........................................117

Quadro 26 - Perfis dos executivos entrevistados................................................................167 


\section{LISTA DE GRÁFICOS}

Gráfico 01 - O impacto da mudança da tecnologia incremental e de ruptura..........................54

Gráfico 02 - Evolução dos acessos em telecomunicações, por categoria.................................65

Gráfico 03 - Evolução da densidade da telefonia celular......................................................66

Gráfico 04 - Divisão do mercado de telefonia celular, em dezembro/2012 .............................66

Gráfico 05 - Evolução das participações de mercado das operadoras celulares.......................67

Gráfico 06 - Evolução das participações de mercado das operadoras celulares nos segmentos

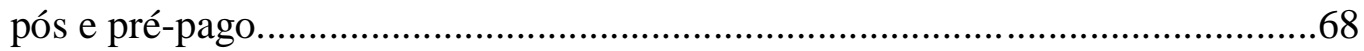

Gráfico 07 - Evolução da base de clientes da telefonia celular vs. tecnologia de rede............69

Gráfico 08 - Evolução de parque e share de mercado Vivo, de 2003 a 2006..........................98

Gráfico 09 - Evolução de receita e share de receita Vivo, de 2003 a 2006............................99

Gráfico 10 - Evolução de celulares por tipo de tecnologia no mundo....................................100

Gráfico 11 - Cenário de posicionamento das marcas.............................................................110

Gráfico 12 - Cenário de associação aos atributos de imagem de marca.................................112

Gráfico 13 - Resultados gerais de satisfação do cliente com a nova tecnologia GSM..........138

Gráfico 14 - Opinião do cliente sobre a qualidade de sinal com a nova tecnologia GSM.....138

Gráfico 15 - Opinião do cliente sobre a imagem da Vivo com a nova tecnologia GSM.......139

Gráfico 16 - Evolução da imagem de marca com o novo posicionamento.............................140

Gráfico 17 - Desempenho nos principais indicadores de saúde de marca............................141

Gráfico 18 - Desempenho nos principais indicadores de equity de marca............................141

Gráfico 19 - Evolução de resultados operacionais da empresa............................................143

Gráfico 20 - Evolução do EBITDA e da margem EBITDA da empresa................................144 


\section{LISTA DE ILUSTRAÇÕES}

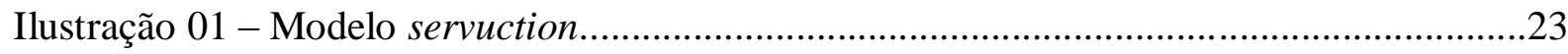

Ilustração 02 - Processo de decisão de compra em serviços...................................................24

Ilustração 03 - Principais decisões nos 4 P's do mix de marketing........................................28

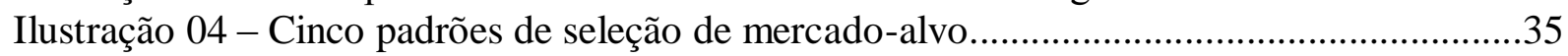

Ilustração 05 - Modelo de planejamento de identidade de marca.............................................38

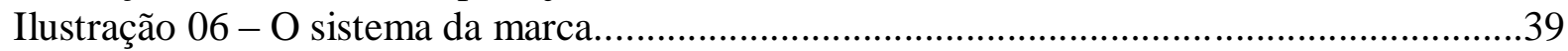

Ilustração 07 - Modelo sistêmico dos antecedentes e conseqüências da marca.......................40

Ilustração 08 - Modelo de planejamento de identidade de marca..........................................41

Ilustração 09 - Componentes do marketing estratégico e entrega de valor...............................50

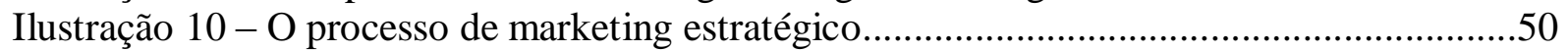

Ilustração 11 - Esquema do processo de marketing ............................................................51

Ilustração 12 - Matriz de tipos de inovação.........................................................................52

Ilustração 13 - Forças que formam a estratégia de comercialização, com a mudança

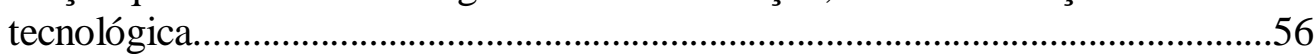

Ilustração 14 - Evolução tecnológica das famílias CDMA e GSM.........................................58

Ilustração 15 - Descrição e facilidades das gerações de tecnologia celular.............................59

Ilustração 16 - Modelo de camadas da Indústria de Infocomunicação....................................61

Ilustração 17 - Regiões do SMP (Serviço Móvel Pessoal).....................................................63

Ilustração 18 - Áreas do SMC (Serviço Móvel Celular)........................................................63

Ilustração 19 - Mapa de cobertura por banda de frequência...................................................64

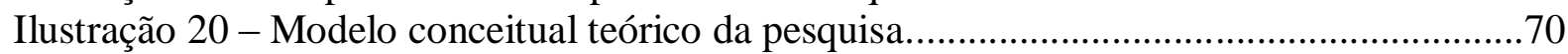

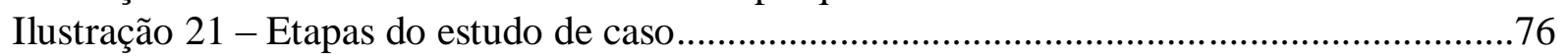

Ilustração 22 - Tipos básicos de projetos para estudos de casos............................................77

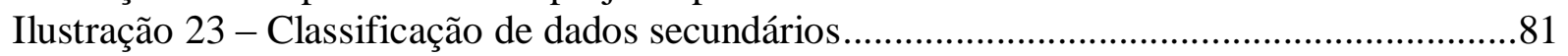

Ilustração 24 - Histórico do mercado de telecomunicação móvel no Brasil 1998 -2008.........86

Ilustração 25 - Operadoras formadoras da empresa Vivo como joint venture .........................88

Ilustração 26 - Tecnologias de rede utilizadas pela Vivo logo após o lançamento...................89

Ilustração 27 - Logo e ícones constituintes da identidade de marca Vivo..............................90

Ilustração 28 - Foco de atuação da marca Vivo em 2003 ..................................................91

Ilustração 29 - Foco de atuação da marca Vivo em 2004-2005 ...........................................92

Ilustração 30 - Visão do posicionamento Vivo e objetivos em 2005 ......................................93

Ilustração 31 - Campanhas de comunicação Vivo, de promoção da tecnologia CDMA.........93

Ilustração 32 - Exemplo de aplicação do selo CDMA na comunicação Vivo.........................94

Ilustração 33 - Foco de atuação da marca Vivo em 2006-2007...........................................95

Ilustração 34 - Foco de atuação das marcas concorrentes, entre 2003 e 2007 .........................96

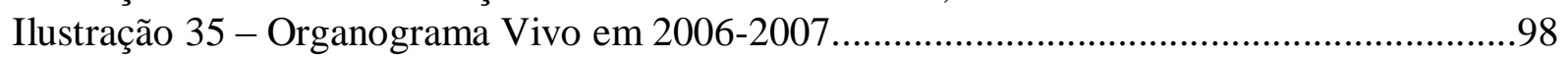

Ilustração 36 - Mapa cognitivo dos fatores condicionantes para o evento-foco.....................101

Ilustração 37 - Estrutura do comitê do Projeto W................................................................104

Ilustração 38 - Discurso interno da presidência - CDMA ou GSM? Ambos........................105

Ilustração 39 - Discurso interno da presidência - Desafios para 2007..................................106

Ilustração 40 - Diretrizes estratégicas 2007 - Projeto Impulso..............................................108

Ilustração 41 - Motivações para um novo posicionamento Vivo..........................................109

Ilustração 42 - Avaliação da assinatura de posicionamento vigente em 2006........................109

Ilustração 43 - Posicionamento Vivo vigente x pretendido.................................................112

Ilustração 44 - Racional para novo posicionamento "Vivo. Sinal de qualidade"...................116

Ilustração 45 - Novos elementos de marca e nova assinatura de posicionamento..................124

Ilustração 46 - Estratégia de comunicação do novo posicionamento......................................124 
Ilustração 47 - Comercial de abertura da $1^{\text {a }}$ fase de comunicação do novo posicionamento......125

Ilustração 48 - Comercial de sequência da $1^{\text {a }}$ fase de comunicação do novo posicionamento...126

Ilustração 49 - Anúncio impresso da $1^{\text {a }}$ fase de comunicação do novo posicionamento............127

Ilustração 50 - Comercial de abertura da $2^{\text {a }}$ fase de comunicação do novo posicionamento.......128

Ilustração 51 - Anúncios impressos da $2^{\mathrm{a}}$ fase de comunicação do novo posicionamento..........129

Ilustração 52 - Comercial do novo formato de comunicação para serviços e ofertas.................129

Ilustração 53 - Anúncios do novo formato de comunicação para serviços e ofertas..................130

Ilustração 54 - Face do Vivo Chip, com o novo sim card GSM.............................................132

Ilustração 55 - Nova assinatura de posicionamento aplicada nas lojas da operadora.................133

Ilustração 56 - Opinião do cliente sobre a campanha de lançamento do novo

posicionamento 


\section{INTRODUÇÃO}

Este estudo se inicia com uma breve contextualização da situação problema que se pretende investigar. Na sequência deste capítulo apresentam-se ainda os objetivos e as questões de pesquisa, além das definições teóricas e operacionais das variáveis e termos relevantes utilizados. Por fim, destaca-se o pressuposto conceitual assumido no estudo.

\subsection{Contextualização do tema e problematização}

Hoje se percebem mudanças radicais no ambiente de negócios que interliga empresas e consumidores, em virtude de forças sociais importantes e algumas vezes interligadas que criaram novos comportamentos, oportunidades e desafios, dos quais a mudança tecnológica é um dos mais relevantes (CASTELLS; 1999). Ocorre uma evolução das relações econômicas, antes marcadamente caracterizadas pela produção e consumo em massa, para um momento em que os níveis de produção têm se tornado mais precisos e as ofertas e comunicações, mais direcionadas.

A partir de medidas como desregulamentação de mercados e privatizações, as bases para a competição têm se alterado, gerando mais oportunidades de crescimento para as empresas e o resultado tem sido o aumento e ampliação da concorrência (SIFFERT FILHO; SILVA, 1999; ADNER; ZEMSKY, 2005). Neste cenário de alta competitividade, o papel do cliente ganha mais relevância, à medida que anseia por produtos e serviços que atendam às suas necessidades de forma cada vez mais personalizada e conveniente. $\mathrm{O}$ acesso à informação lhes propicia ainda um processo de compra mais inteligente e maior capacidade de distinção entre as diversas ofertas de produtos e serviços.

Segundo Hooley et al. (2001), a sobrevivência e o crescimento das empresas num ambiente com estas características dependem, entre outras coisas, da capacidade que elas possam ter de inovar, de se diferenciar de seus concorrentes, e da sensibilidade em relação às demandas e mudanças que ocorrem em seus ambientes e mercados consumidores.

A inovação acontece em ciclos cada vez menores, trazendo novas funcionalidades, reeducando o comportamento de adoção e uso de produtos e serviços pelos consumidores, o que traz uma nova dinâmica no relacionamento entre empresas e clientes (KAPLAN; NORTON, 1997). Para os gestores, o desafio é claro: é preciso avaliar criticamente as realidades externas e internas à empresa e de fato agir conscientemente em torno de uma direção. Ou a empresa de fato interpreta o significado e os benefícios de uma dada inovação 
em prol do negócio e de benefícios para o consumidor e se move, realizando todo um conjunto de investimentos e revisão de processos e competências para acompanhar as novas configurações do mercado, das quais a inovação tecnológica é um dos aspectos principais, ou no caso de se manter a revelia das mudanças ambientais, pode sofrer com inúmeras formas de perda de competitividade. Importante é sublinhar que, se existem os riscos de desatualização, perda de mercado e lucratividade no caso de não se acompanhar as novas configurações de mercado, existem riscos ainda maiores no sentido de se mudar a forma de atuação de uma empresa no mercado.

Setores emergentes de serviços ganham representatividade em muitas economias que antes eram conhecidas pelo seu poder industrial, além de captar e dominar grande parte da força de trabalho. Ainda segundo Hoffman et al. (2009), neste setor, o imperativo de serviço reflete a visão de que os aspectos intangíveis dos produtos estão se tornando características fundamentais que os diferenciam no mercado.

Para Kotler e Keller (2006), os profissionais de marketing de serviços precisam ser capazes de transformar serviços intangíveis em benefícios concretos. As empresas devem desenvolver primeiro uma imagem clara de como querem que seja a percepção do cliente quanto a determinada experiência e depois planejar um conjunto consistente de sinais de contexto e desempenho para sustentar essa experiência. O posicionamento é uma decisão estratégica porque trabalha com a percepção do consumidor, influenciando o processo de decisão de compra. Palmer e Cole (1995) destacam que os serviços podem ser posicionados isoladamente ou como parte da empresa, além de afirmarem que os consumidores valorizam mais o posicionamento da empresa do que de serviços individuais.

De acordo com Da Rocha e Ferreira da Silva (2006), a maior parte dos estudos realizados em marketing de serviços no Brasil pode ser caracterizada como testes empíricos que utilizam instrumentos de medida desenvolvidos por pesquisadores de outros países. Seria desejável, porém, uma ampliação do foco atualmente existente, além de se buscar explorar novas questões comportamentais e estratégicas relacionadas a serviços. Seth et al. (2005) propõem, como um dos temas a estudar, o papel da tecnologia, em particular a tecnologia da informação, no marketing de serviços.

Um setor de destaque, com grande importância social e econômica, na indústria de serviços brasileira é o de telecomunicações. Este setor, após o processo de privatização ocorrido na década de 90, passou a ser o responsável pelo provimento do serviço de comunicação a toda a 
população brasileira. Diversas novas empresas surgiram em todo o território brasileiro para substituir o Estado com a promessa de inovação e melhores níveis de qualidade na prestação do serviço. Novas formas de relacionamento entre cliente e empresa foram estabelecidas e o envolvimento do consumidor com a avaliação do serviço de telecomunicação passou a ser cada vez mais relevante (NEVES, 2002; FRONTINI, 2008). A concorrência entre empresas num mesmo mercado consumidor aumentou e questões como marca, posicionamento e oferta tornaram a atividade do profissional de marketing do setor mais desafiadora.

Santa Rita e Sbragia (2006), em estudo no âmbito da inovação em serviços, avaliaram os condicionantes da competitividade da telefonia móvel. Os autores concluíram que, entre os fatores considerados relevantes como barreira de entrada à competição, o posicionamento da marca no mercado constitui-se como o mais importante, garantindo maior competitividade às empresas desse setor.

\section{Quadro 01 - Escores médios que definem o grau de Competitividade - Barreiras à Entrada}

\begin{tabular}{|c|c|c|c|c|c|c|c|}
\hline Barreiras à Entrada & 1 & 2 & 3 & 4 & 5 & Média & $\begin{array}{l}\text { Desvio- } \\
\text { padrão }\end{array}$ \\
\hline $\begin{array}{l}\text { Economias de escala relacionadas à fabricação, compras, } P \& D \text {, marketing, rede de } \\
\text { serviços, força de vendas ou distribuição. }\end{array}$ & & & & & & 3,68 & 0,582 \\
\hline Posicionamento da marca no mercado. & & & & & & 4,11 & 0,583 \\
\hline $\begin{array}{l}\text { Politica governamental vinculada a licenças de funcionamento, } \\
\text { indices de segurança e de eficiência do produto, padrões para teste do produto, etc. }\end{array}$ & & & & & & 3,17 & 1,043 \\
\hline $\begin{array}{l}\text { Capital investido em publicidade, pesquisa e desenvolvimento, } \\
\text { instalações, crédito ao consumidor, estoques, capital de giro, etc. }\end{array}$ & & & & & & 3,21 & 0,713 \\
\hline $\begin{array}{l}\text { Acesso aos canais de distribuição através de descontos de preço, } \\
\text { verbas para campanhas de publicidade, esforços de vendas, etc. }\end{array}$ & & & & & & 3,84 & 0,688 \\
\hline $\begin{array}{l}\text { Custos alcançados por meio de tecnologia patenteada, localizações favoráveis, } \\
\text { subsidios oficiais, curva de aprendizagem, etc. }\end{array}$ & & & & & & 2,72 & 0,752 \\
\hline $\begin{array}{l}\text { Custos de mudanças devido à alteração de um fornecedor para outro, novo } \\
\text { treinamento, custo de equipamentos auxiliar, etc. }\end{array}$ & & & & & & 2,56 & 0,784 \\
\hline $\begin{array}{l}\text { Retaliações previstas com recursos substanciais através de excedente de caixa, } \\
\text { capacidade de contrair empréstimos, excesso de capacidade de oferta, equilibrio com } \\
\text { os canais de distribuição e clientes, etc. }\end{array}$ & & & & & & 2,92 & 1,240 \\
\hline
\end{tabular}

Fonte: SANTA RITA; SBRAGIA; 2006, p. 91.

Vale sublinhar que o setor de telecomunicação móvel vem apresentando um nível de competitividade crescente, desde o momento em que o processo de privatização instaurou a divisão do mercado em um número maior de competidores, que passaram a atuar com formas de tecnologia diversas. Esse fato levou a uma diferenciação da proposta de valor das empresas, de acordo com a tecnologia utilizada no processo de prestação do serviço.

Frontini (2008) estudou os impactos da tecnologia (representada pela convergência digital entre telecomunicações e informática) em modelos de gestão estratégica, identificando os 
ajustes requeridos, ou seja, como as empresas devem rever seus modelos de gestão para competir perante um contexto tecnológico convergente, concluindo que a inovação de ruptura requer o envolvimento de múltiplas competências, capacitações e aplicações que, usualmente, não são totalmente detidos por operadoras móveis.

Dodourova (2003) estudou ainda como os principais recursos competitivos e capacidades dentro da indústria de telecomunicações móvel mudaram ao longo do tempo, concluindo que ocorre uma adaptação de tais recursos com o estabelecimento de novas estratégias, motivadas pelo surgimento de novos mercados ou novas tecnologias.

Jurisic e Azevedo (2011) destacaram a importância do setor de telecomunicações móvel no campo de estudos das estratégias de marketing e investigaram a relação entre marcas de operadoras celulares do mercado português e seus clientes, chegando à conclusão de que fatores como reputação da marca e satisfação são cruciais para prever a força das relações cliente-marca.

É justamente neste ponto que este estudo pretende avançar no campo do estudo do marketing de serviços, considerando a tecnologia como um fator influenciador de mudanças no processo de posicionamento de marketing. O papel da tecnologia deverá ser considerado na ótica da introdução de inovações disruptivas na prestação de serviço ao cliente da telecomunicação móvel.

Apresenta-se, portanto, a questão-problema para este estudo, com o intuito de contribuir para o entendimento do tema proposto:

“Como o posicionamento de marcas de serviços no setor de telecomunicações móvel é afetado pela introdução de inovação disruptiva?"

\subsection{Objetivos de pesquisa}

O objetivo geral da pesquisa é estudar o posicionamento de marcas de serviços no setor de telecomunicações móvel e como ele é afetado pela introdução de inovação disruptiva. 
Entre os objetivos específicos estão:

- Levantar quais os fatores (atributos, critérios) relevantes para os clientes-alvo no posicionamento de marca de serviços de telecomunicações móvel;

- Examinar eventuais diferenças existentes entre as opiniões dos clientes e o posicionamento desejado pela empresa;

- Identificar na empresa do setor de serviços de telecomunicações móvel as inovações disruptivas introduzidas em determinado período e as mudanças de posicionamento ocorridas;

- Verificar como a mudança de posicionamento afeta o composto de marketing da empresa e quais os resultados alcançados.

\subsection{Definições teóricas e operacionais das variáveis e termos relevantes}

As definições teóricas indispensáveis para situar o escopo do estudo são apresentadas como segue:

- Posicionamento: Para Ries e Trout (2007), pioneiros na definição deste conceito, posicionamento é o que se faz na mente do cliente em perspectiva, ou seja, o produto é posicionado na mente do comprador em potencial. As empresas devem trabalhar uma categoria de atributo ou benefício que um produto ou uma marca possam possuir, e que sejam convenientes para os consumidores, e, desse modo, tomar-se a posição de “a número um” nestes atributos. Segundo Hooley e Saunders (1996), questões como a identificação do mercado-alvo e a criação de uma vantagem competitiva para atender o mercado escolhido constituem o posicionamento competitivo da empresa. Operacionalmente, o conceito será apreendido pelas decisões estratégicas de posicionamento, com a compreensão da identidade de marca pretendida, além do conjunto das ações relacionadas ao composto de marketing, derivadas da estratégia de posicionamento. Do ponto de vista do consumidor, será avaliado o conjunto de associações à marca, na opinião de clientes e não-clientes, que forma a imagem da marca da empresa.

- Serviços: é a proposta de valor de uma empresa a uma pessoa ou a um grupo de pessoas com o objetivo de satisfação de suas necessidades. Lovelock e Wright (2001) 
defendem que serviços são atividades econômicas que criam valor e fornecem benefícios para clientes em tempos e lugares específicos, como decorrência da realização de uma mudança desejada no - ou em nome do - destinatário do serviço. Operacionalmente será considerada a prestação de serviço realizada pela empresa ao cliente. Para esta pesquisa, necessariamente envolve relacionamento contínuo empresa-cliente e envolve o pagamento em troca da prestação de serviço, que poderá ser a contratação de um plano de serviços de telefonia celular ou a compra de recarga para uso nas modalidades de voz ou dados;

- Inovação disruptiva: Khan e Khan (2009) definem a inovação em serviços como a introdução e aplicação intencional de ideias, processos, procedimentos, ou produtos relacionados a serviços em uma empresa, desenhados de forma a obter um benefício significativo para um indivíduo, para o grupo ou para a empresa, considerando as características distintivas dos serviços e a satisfação do consumidor. Para Christensen (2003), a inovação disruptiva não tem a pretensão de trazer melhores produtos aos clientes estabelecidos nos mercados existentes: introduz produtos e serviços com desempenho inferior aos existentes, mas são mais simples, mais convenientes e menos dispendiosos, com maior apelo para clientes novos ou menos exigentes. Uma vez que o produto disruptivo ganha posição no mercado, um ciclo de melhoria começa. E como o ritmo do progresso tecnológico ultrapassa as necessidades do cliente, a tecnologia até então inferior melhora o suficiente até interceptar as necessidades dos clientes mais exigentes. Operacionalmente trata-se da introdução de novos serviços, novas facilidades ou uma nova forma de realizar o serviço existente, melhorando a forma como o serviço é prestado ou atendendo a novas necessidades. Para esse estudo, envolve necessariamente mudança de tecnologia e poderá ser identificado pela tecnologia de rede utilizada para a prestação de serviço de telecomunicação celular e também pela tecnologia embarcada nos aparelhos utilizados para conexão de voz (telefones) e conexão de dados (modens e placas de acesso móvel), no caso uma mudança de tecnologia de rede CDMA para GSM.

- Composto de marketing: para McCarthy (1960) apud Toledo et al. (2002), o composto de marketing compreende decisões que a empresa precisa tomar sobre as variáveis controláveis, com o intuito de atingir o mercado-alvo. Para organizar e simplificar as decisões a serem tomadas, McCarthy reuniu as variáveis em quatro grupos, conhecidos como os "4 Ps" do marketing: produto, preço, promoção e praça 
(distribuição). Kotler e Keller (2006) consideram o composto de marketing um dos conceitos essenciais do marketing moderno, definindo-o como um conjunto de ferramentas de marketing que a empresa utiliza para perseguir seus objetivos de marketing no mercado-alvo. Para o universo dos serviços, Booms e Bitner (1981), propuseram a consideração de três variáveis adicionais aos “4 P's": pessoas, processos e instalações. Operacionalmente, são as decisões executadas pela empresa do setor de telecomunicações móvel quanto às características do serviço prestado. Em produto: nível de qualidade de rede, benefícios advindos da tecnologia empregada e variedade de serviços de acordo com as necessidades dos clientes; em preço: preço dos planos e recargas, preço dos aparelhos, relação custo-benefício; praça: canais de contratação do serviço e de relacionamento com a operadora; promoção: marca, propaganda, publicidade, promoção de vendas, marketing direto, entre outros; pessoas: colaboradores internos, equipe de vendas direta e indireta, equipe de relacionamento; processos: relacionados aos procedimentos e mecanismos de operacionalização da prestação do serviço em vendas e infraestrutura de rede; e por fim, instalações: considera-se o ambiente de prestação de serviço, como lojas, revendas e site na internet.

- Setor de telecomunicações: de acordo com Pires (1999), a formação do setor de telecomunicações no Brasil respondeu ao novo contexto de globalização econômica, de evolução tecnológica setorial, de novas exigências de diversificação e modernização das redes e dos serviços, além de permitir a universalização da prestação de serviços básicos, tendo em vista a elevada demanda reprimida no país. Operacionalmente, nesta pesquisa considera-se parte deste setor, representada pelo mercado de telecomunicação móvel apenas. Neste mercado estão incluídas as empresas operadoras celulares representadas pelas marcas Brasil Telecom, Claro, CTBC, Oi, Sercomtel, TIM e a empresa-foco, Vivo.

\subsection{Justificativas e relevância do trabalho}

A justificativa para a opção por este tema de estudo reside primeiramente na crescente importância do marketing de serviços, tanto na economia global como nos estudos acadêmicos. No entanto, este campo de estudo é considerado ainda limitado, oferecendo oportunidades para contribuição relevante na ampliação do conhecimento, em especial nas 
questões que relacionam a tecnologia como fator motivador de mudanças na gestão de serviços das organizações.

Neste contexto, a justificativa pelo foco na estratégia de posicionamento se explica pelo fato de existirem diversas abordagens teóricas para este processo, tornando-se relevante investigar como é gerido por empresas do setor de serviços na atual conjuntura de evolução tecnológica constante.

A consideração do setor de telecomunicações móvel como ambiente de estudo justifica-se pela relevância deste mercado para o País. Desde a sua importância social, como responsável pelo provimento de comunicação para a sociedade em geral, até a sua importância econômica, representada pelos expressivos valores de receita gerados e também de investimentos realizados em infraestrutura, mas principalmente em ações relacionadas à gestão de marketing, tornando rico e relevante o estudo da atuação das operadoras. A proximidade do autor deste trabalho com o setor também merece menção, agregando experiência e precisão à realidade estudada.

\subsection{Pressupostos conceituais}

O pressuposto conceitual desta pesquisa é o de que, conforme apresentam Narver e Slater (1990), um negócio que assuma sua orientação para o mercado, irá incrementar o seu desempenho de marketing. Estes autores acumulam estudos consagrados (KOTLER, 1984; KOTLER; ANDREASEN, 1987; LEVITT, 1960; WEBSTER, 1988; HOUSTON, 1986; KOHLI; JAWORSKI, 1990) que vão ao encontro desse pressuposto.

Ainda segundo Narver e Slater (1990), a orientação para o mercado é a cultura organizacional que cria, mais eficazmente e eficientemente, os comportamentos necessários para a criação de valor agregado para os consumidores, além de desempenho continuamente superior para o negócio.

Ferraresi (2010), após extensa revisão do tema, defende que, relativo aos componentes de critério de tomada de decisão, o foco no longo prazo está ligado diretamente à sobrevivência e a competitividade da empresa, ou seja, deve-se prevenir a superação de suas vantagens pelos competidores, o que pressupõe investimento para continuar criando valor, e que exige uma perspectiva de longo prazo, tendo a lucratividade como objetivo. 
Considera-se, portanto, no escopo deste estudo, que a manipulação das estratégias e ferramentas de marketing, e mais especificamente neste contexto, do posicionamento de uma empresa, seja realizada com a evidente expectativa da melhoria de desempenho, tanto para o cliente como para a empresa.

\subsection{Estrutura do trabalho}

De forma a atingir os objetivos propostos, este trabalho está estruturado em cinco grandes capítulos.

O capítulo 1, "Introdução", situou o tema que se pretende estudar, apresentando a questão de pesquisa que será investigada, dentro dos pressupostos conceituais assumidos;

O capítulo 2, de "Fundamentação teórica", traz uma revisão da literatura em quatro grandes blocos integrados, que buscam estabelecer uma relação entre os construtos de posicionamento e inovação disruptiva, no contexto do marketing de serviços, além de apresentar a realidade do setor de telecomunicações brasileiro.

O capítulo 3, "Metodologia de pesquisa", detalha os aspectos metodológicos orientadores para a busca de informações para o trabalho e explicita a decisão pelo método do estudo de caso e procedimentos para o trabalho de campo.

O capítulo 4, "Apresentação de resultados", apresenta a consolidação da pesquisa conduzida no caso da empresa Vivo S/A, baseada nas entrevistas em profundidade e nos dados secundários coletados.

O capítulo 5, "Considerações finais", traz a análise conclusiva do caso alinhado à teoria e finaliza com as limitações do estudo e recomendações para estudos futuros. 


\section{FUNDAMENTAÇÃO TEÓRICA}

A fundamentação teórica foi estruturada de forma a suportar a discussão em torno da questão de pesquisa. Assim, a revisão pretende:

- Situar a discussão no campo de atuação de marketing de serviços, considerando os aspectos distintivos e desafios de negócio;

- Enfocar o processo que é o objeto de estudo - posicionamento - numa perspectiva integrada aos processos estratégicos organizacionais;

- Abordar e entender o conceito de inovação disruptiva e efeitos de sua introdução

- Caracterizar o setor de telecomunicações brasileiro e suas especificidades.

Neste sentido, a fundamentação teórica terá quatro blocos: o primeiro trata das especificidades das ofertas de serviços, além de abordar o composto de marketing de serviços; o segundo traz o conjunto de temas que é foco desse estudo: segmentação, gestão de marcas e posicionamento numa perspectiva integrada; o terceiro discute o conceito de inovação disruptiva enquanto processo de evolução tecnológica e termina por explicar questões específicas das tecnologias de conexão móvel utilizadas pelas operadoras de telecomunicação móvel no Brasil; e, por fim, o quarto bloco propicia uma visão geral e histórica do setor de telecomunicações brasileiro, com foco específico no mercado móvel.

Quadro 02 - Blocos temáticos da fundamentação teórica

\begin{tabular}{|ll|}
\hline 2.1 & Fundamentos de marketing de serviços \\
\hline 2.1.1 & Marketing de serviços: o setor e estudos \\
\hline 2.1.2 & Características distintivas de serviços \\
\hline 2.1.3 & Experiência de consumo e relacionamento em serviços \\
\hline 2.1.4 & Modelo de decisão do cliente em serviços \\
\hline 2.1.5 & Gestão do composto de marketing de serviços \\
\hline
\end{tabular}

\begin{tabular}{|ll|}
\hline 2.2 & Segmentação de mercado, gestão de marcas e posicionamento de marcas \\
\hline 2.2 .1 & Segmentação \\
\hline 2.2 .2 & Gestão de marcas \\
\hline 2.2.3 & Posicionamento \\
\hline
\end{tabular}

2.3 Introdução de inovações disruptivas

2.3.1 Conceituação de inovações disruptivas

2.3.2 Tecnologias de conexão móvel no Brasil

\subsection{Setor de serviços de telecomunicações no Brasil}

2.4.1 Áreas de atuação e bandas de freqüência das operadoras celulares

2.4.2 Evolução do setor de telecomunicações brasileiro

2.4.3 Evolução dos acessos celulares por tecnologia no Brasil 


\subsection{Fundamentos de marketing de serviços}

\subsubsection{Marketing de serviços: o setor e estudos}

O setor de serviços tem apresentado um aumento de participação considerável na economia global. Segundo Lovelock e Wright (2001), os serviços constituem o grosso da economia de hoje, não só no Brasil, onde respondem por 55\% do Produto Interno Bruto (PIB), mas também no mundo - nos EUA e no Canadá respondem por $72 \%$ e $67 \%$ do PIB, respectivamente. Las Casas (2000) destaca o maior poder aquisitivo da população, que permite que as tarefas tidas como mais rotineiras sejam transferidas a terceiros e prestadores de serviços. Grönroos (1995) defende ainda que à medida que a sociedade se transforma, as pessoas se tornam mais ricas e uma atitude diferente com relação à vida se desenvolve. As pessoas então passam a gastar mais em serviços.

Como apontam Da Rocha e Ferreira da Silva (2006), o interesse pelo marketing de serviços, particularmente nos últimos 20 anos, encontra-se ligado à importância econômica dos serviços nas economias pós-industriais. Mais ainda, à medida que se reduzem as possibilidades de diferenciação de produtos, devido ao amadurecimento dos mercados, as empresas são levadas a desenvolver vantagens competitivas centradas na oferta ampliada de serviços.

As primeiras publicações sobre o tema discutiam a natureza dos serviços, suas características e a aplicabilidade dos conceitos tradicionais de marketing ao marketing de serviços. Entre os pioneiros no desenvolvimento teórico cabe destacar os trabalhos de Grönroos e Lovelock, de onde derivam conceitos iniciais de qualidade percebida dos serviços, além dos trabalhos de Parasuraman, Zeithaml e Berry, com foco na teoria dos gaps de qualidade, com a proposição da escala Servqual de qualidade percebida em serviços.

Em levantamento sobre estudos brasileiros realizados no âmbito do marketing de serviços, Da Rocha e Ferreira da Silva (2006) concluíram que a maioria dos estudos está fortemente concentrada em investigar o comportamento pós-compra de serviços, seguindo a linha mestra dos estudos internacionais. Mais ainda, a maior parte dos estudos se concentrou em dois construtos: qualidade e satisfação. Indicam ainda que explorações teóricas e empíricas em torno do tema de cenários de serviços são escassas e concentradas e que o estudo do processo 
de escolha do consumidor de serviços também se limitou a poucos estudos e centros de investigação.

Pode-se dizer que vivemos uma nova era de serviços globais. Dentre os aspectos citados por Hoffman et al. (2009) como fatores críticos dessa nova realidade, vale ressaltar o maior envolvimento dos clientes nas decisões estratégicas de negócio, o aumento da autonomia dos funcionários para desenvolver soluções personalizadas nas solicitações de clientes e principalmente, o "imperativo de serviço", em que os aspectos intangíveis do produto estão se tornando cada vez mais características fundamentais que os diferenciam no mercado.

Os efeitos dessa nova realidade são majoritariamente positivos e muitos autores consideram que o aumento do setor de serviços tem sido o responsável pelo aumento da riqueza e do nível de emprego na sociedade (GRÖNROOS, 1995; LOVELOCK; WRIGHT, 2001; HOFFMAN et al., 2009; ZEITHAML; BITNER, 2003).

\subsubsection{Características distintivas de serviços}

Os serviços são a proposta de valor de uma organização a uma pessoa ou a um grupo de pessoas com o objetivo de satisfação de suas necessidades. Para Lovelock e Wright (2001) serviço é um ato ou desempenho oferecido por uma parte à outra. Embora o processo possa estar ligado a um produto físico, o desempenho é essencialmente intangível e normalmente não resulta em propriedade de nenhum dos fatores de produção. Corroboram com esta visão Zeithaml e Bitner (2003), quando afirmam que fica claro que os serviços não são produzidos apenas por empresas de serviços, mas também fazem parte daquilo que os fabricantes de produtos manufaturados oferecem. Ainda neste sentido, Grönroos (1995) defende que a maioria das empresas de fabricação no chamado setor industrial da economia tem que oferecer a seus clientes uma variedade de serviços como parte integral de suas ofertas.

Pode-se dizer que a distinção entre o que é um produto do que é um serviço ou um serviço complementar não é algo claro. Hoffman et al. (2009) acreditam que na verdade é difícil, se não impossível, fornecer um exemplo de um bem puro ou de um serviço puro. Quando comparados aos bens físicos, quatro características básicas podem ser identificadas nos serviços, de acordo com Grönroos (1995): (1) serviços são mais ou menos intangíveis; (2) serviços são atividades ou uma série de atividades em vez de coisas; (3) serviços são, pelo menos até certo ponto, produzidos e consumidos simultaneamente; (4) o cliente participa do 
processo de produção, pelo menos até certo ponto. Parasuraman et al. (1985), após extensa revisão do tema com base em diversos autores, listaram quatro características que diferenciam serviços de produtos, ou bens de consumo: intangibilidade, inseparabilidade, heterogeneidade e perecibilidade.

Conforme revisão realizada por Zolfagharian (2007), a literatura sugere diversas diferenças entre serviços e produtos. Duas dessas diferenças, nomeadamente intangibilidade e inseparabilidade da produção-consumo são fundamentais e todas as outras características, incluindo perecibilidade e heterogeneidade, são derivadas das duas primeiras (ZEITHAML; PARASURAMAN; BERRY, 1985; BATESON, 1985; EIGLIER, 1977; HILL, 1977 apud ZOLFAGHARIAN, 2007).

Intangibilidade significa que falta aos serviços a substância física. Pelo fato de serviços serem atuações e ações mais do que propriamente objetos, eles não ser vistos, sentidos, ouvidos, cheirados ou tocados da mesma forma que podemos sentir os bens tangíveis Assim, além de não poderem ser armazenados, não podem ser patenteados legalmente e novos conceitos de serviços podem ser facilmente copiados pela concorrência. Além disso, torna-se difícil determinar os custos reais da "unidade de serviço" e a relação preço / qualidade é complexa (ZEITHAML; BITNER, 2003). Lovelock e Wright (2001) acrescentam ainda que a noção de serviço como realização que não pode ser tocada ou embrulhada e carregada leva a uma metáfora teatral para a administração de serviços.

Portanto, as estratégias desenvolvidas para contrabalançar os desafios propostos pela intangibilidade incluem o uso de indícios tangíveis como evidência física concreta, desenvolvimento da imagem organizacional e de fontes pessoais de informação que os clientes acessam quando escolhem provedores de serviços (HOFFMAN et al., 2009; GRÖNROOS, 1995).

Inseparabilidade diz respeito à relação intrínseca entre provedores de serviços e seus clientes. De modo geral, os serviços são produzidos e consumidos simultaneamente. Diferentemente dos produtores de bens, os provedores de serviços estabelecem interações cara a cara com seus clientes, que estão diretamente envolvidos no processo de produção do serviço (HOFFMAN et al., 2009). Zeithaml e Bitner (2003, p.37) acrescentam ainda que "enquanto a maior parte dos bens é produzida antecipadamente para então ser vendida e consumida, a 
maior parte dos serviços é primeiro vendida, e então, produzida e consumida simultaneamente”. Para Grönroos (1995) é a parte visível das atividades de produção que conta na mente do cliente. Assim, o controle da qualidade e o marketing têm que ter lugar, portanto, no momento e no lugar da produção e consumo do serviço simultaneamente. Por fim, Lovelock e Wright (2001) destacam ainda que os clientes sejam ativamente envolvidos em ajudar a criar o produto do serviço seja pelo autoatendimento ou pela cooperação com o pessoal de serviços. Dessa forma, as empresas de serviços têm muito a ganhar por tentarem educar seus clientes para torná-los mais competentes. Entre as possíveis soluções para os problemas de inseparabilidade, Hoffman et al. (2009) sugerem o maior cuidado com a seleção e treinamento do pessoal de contato com o público, o gerenciamento do cliente e o uso de múltiplas localizações.

Heterogeneidade relaciona-se à variabilidade inerente ao processo de prestação de serviços, pois dependem de por quem, onde e quando são fornecidos. Segundo Zeithaml e Bitner (2003), a heterogeneidade ocorre pelo fato de dois clientes nunca serem exatamente os mesmos; cada qual terá demandas exclusivas ou suas experiências do serviço ocorrerão de forma muito particular. Em decorrência disso, erros e falhas são mais freqüentes e mais difíceis de ocultar (LOVELOCK; WRIGHT, 2001).

O principal problema de marketing ligado à heterogeneidade é que a padronização e o controle de qualidade são difíceis de serem mantidos regularmente pela empresa de serviços. O potencial de heterogeneidade pode ser ampliado ainda mais quando os serviços são executados por um terceiro (GRÖNROOS, 1995; ZEITHAML; BITNER, 2003). Possíveis estratégias consideram a padronização do processo por máquinas ou alternativamente, a prestação de serviços customizados que satisfazem necessidades individuais do cliente. Essa definição dependerá de uma hierarquia de critérios do cliente tais como preço, velocidade de entrega e consistência de desempenho.

Para Zeithaml e Bitner (2003), a perecibilidade refere-se ao fato de os serviços não poderem ser preservados, estocados, revendidos ou devolvidos. Segundo Hoffman et al. (2009), no entanto, a perecibilidade não se configura como um problema quando a demanda é estável. $\mathrm{O}$ desafio surge quando não há equilíbrio entre a demanda e a oferta de serviços, pois os serviços que não são usados na hora em que foram programados cessam de existir. Grönroos (1995) defende que o planejamento da capacidade se torna uma questão crítica e que embora 
os serviços não possam ser mantidos em estoque, pode-se tentar manter os clientes em estoque. Porém, como apontam Lovelock e Wright (2001), existem limites de tempo em que os clientes estarão dispostos a ficar esperando, pois os clientes de hoje são cada vez mais sensíveis ao tempo, e a velocidade muitas vezes é um elemento fundamental para o bom serviço.

Por fim, Hoffman et al. (2009), propõem, como possíveis soluções à questão da perecibilidade formas de (1) controle estratégico da demanda: por meio da fixação criativa de preços, do uso de um sistema de reservas, do desenvolvimento de serviços complementares ou do desenvolvimento de demanda fora do período de pico; e (2) controle estratégico da oferta: por meio da utilização de funcionários de meio período, de compartilhamento da capacidade com outros prestadores de serviços, de uso de terceiros ou inclusive contando com aumento da participação do cliente no processo.

Assim à luz destas quatro características distintivas, Kotler e Keller (2006) defendem que os profissionais de marketing precisam ser capazes de transformar serviços intangíveis em benefícios concretos. As empresas devem desenvolver primeiro uma imagem de como querem que seja a percepção do cliente quanto a determinada experiência. Depois devem planejar um conjunto consistente de sinais de contexto e desempenho para sustentar essa experiência.

\subsubsection{Experiência de consumo e relacionamento em serviços}

Hoffman et al. (2009) defendem que embora o modelo do processo de decisão do cliente se aplique tanto a bens quanto a serviços, considerações exclusivas a respeito dos serviços aparecem em cada um dos três estágios. Cabe verificar que o estágio de consumo é mais complexo para serviços, pois a produção, a aquisição e o uso dos serviços tornam-se mais complicados em um único processo.

Lovelock e Wright (2001) colocam o "encontro de serviços" como o período de tempo durante o qual os clientes interagem diretamente com um serviço. A experiência de serviço como um todo pode ser reduzida a um único encontro ou abrange uma sucessão de encontro que pode distribuir-se por um determinado período de tempo, envolver vários funcionários e até acontecer em locais diferentes. Para esta mesma ideia, Grönroos (1995) estabeleceu o conceito de 'hora da verdade' como as interações entre os clientes e os representantes da 
empresa ou as várias áreas / setores da empresa. A sobreposição de etapas existente em serviços traz implicações para o marketing:

[...] por causa do extenso processo de prestação do serviço, muitos acreditam que a avaliação pós-compra do cliente ocorre tanto durante quanto depois da utilização dos serviços, e não apenas depois dela. Do ponto de vista do marketing, isso oferece a oportunidade de influenciar diretamente a avaliação do cliente durante o processo de prestação do serviço (HOFFMAN et al., 2009, p.116).

Para ilustrar a importância da experiência do cliente com os diversos elementos do serviço prestado, Langeard et al. (1981) desenvolveram o modelo servuction. Combinando as palavras "service" e "production" o conceito sustenta que o cliente co-produz o serviço que consome e sua percepção sobre o serviço é influenciada por dois tipos de elementos: o que é visível ao cliente (ambiente inanimado, provedores de contato pessoal e outros clientes) e o que não é (a organização e os sistemas invisíveis).

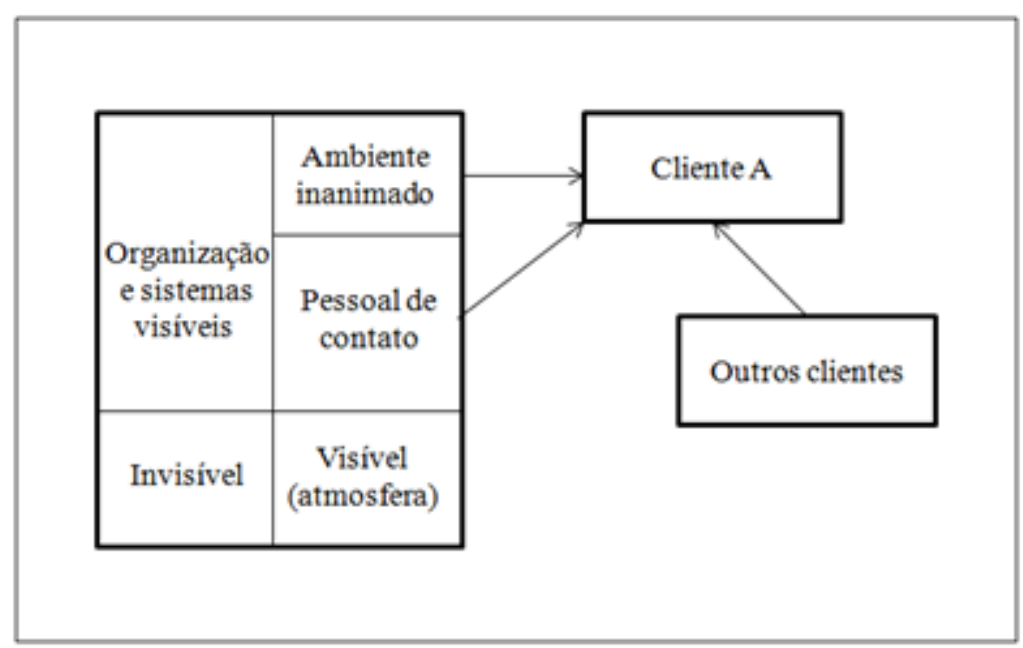

Ilustração 01 - Modelo servuction

Fonte: Adaptado de LANGEARD, E. et al.; 1981, p. 81-104.

Três fatores são visíveis aos clientes: o ambiente físico de serviços, ou servicescape; os provedores de contato pessoal / serviços e os outros clientes. A organização e os sistemas, embora invisíveis, têm profundo impacto na experiência do cliente.

\subsubsection{Modelo de decisão do cliente em serviços}

O modelo do processo de decisão do cliente consiste de três estágios principais: pré-compra, consumo e pós-compra. O estágio de pré-compra consiste nos eventos que ocorrem antes da aquisição do serviço pelo cliente e inclui recepção de estímulos, conscientização do problema, 
busca de informações e avaliação de alternativas. O resultado do estágio de pré-compra é uma decisão que ocorre durante o estágio do consumo.

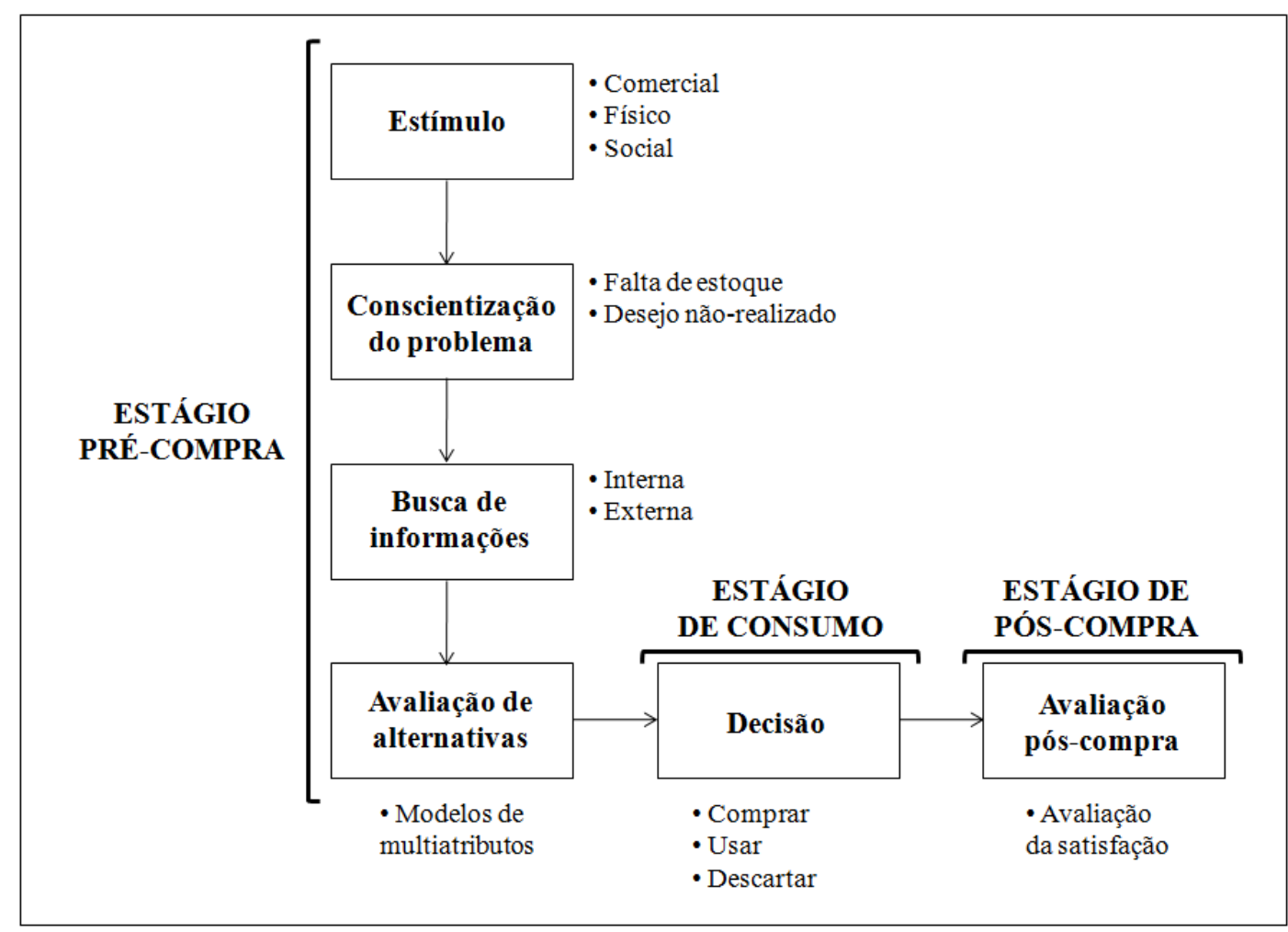

Ilustração 02 - Processo de decisão de compra em serviços

Fonte: Adaptado de HOFFMAN et al; 2009, p. 97.

No estágio de pré-compra, em resumo, os clientes de serviços tendem a (1) perceber nível mais alto de risco associado à compra, (2) tendem a ser mais fiéis a uma marca forte, (3) confiam mais em fontes pessoais de informação, (4) tendem a ter menos alternativas a considerar e (5) optam eles mesmos por executarem o serviço.

Em comparação aos clientes de bens, os de serviços tendem a perceber um nível mais alto de risco durante o estágio de decisão de compra causado principalmente por duas dimensões, (1) conseqüência - grau de importância e/ou perigos derivados de qualquer decisão do cliente, e (2) incertezas - mesmo que o prestador de serviço já tenha realizado o serviço antes, devido à variabilidade, não há como ter garantias de que não ocorrerão falhas.

Entre os tipos de riscos enfrentados pelos clientes de serviços estão: (1) financeiro - risco de haver perdas monetárias, (2) desempenho - riscos de o serviço não atender o objetivo com o qual foi comprado, (3) físico - riscos de causar danos ao comprador, (4) social - risco de 
haver perda social associada a determinada compra e (5) psicológico - compra pode afetar a autoestima do cliente.

Os atributos para avaliação de serviços pré-compra, segundo o modelo, são: (1) atributos de análise, que podem ser determinados antes da compra, (2) atributos de experiência, que somente podem ser determinados durante e após a compra, como simpatia e bom humor e (3) atributos de credibilidade, que são aqueles difíceis de serem avaliados com confiança mesmo após recebimento do bem ou serviço, como qualidade do conserto de um carro, ou o sucesso de uma cirurgia. Por causa da natureza intangível dos serviços, praticamente não existem atributos de análise para reduzir riscos da compra no estágio de pré-compra. Atributos de credibilidade ganham muita importância para serviços principalmente por causa da propriedade da inseparabilidade. E, finalmente, por causa da heterogeneidade, serviços são julgados principalmente por atributos de experiência e credibilidade.

Para reduzir riscos, serviços podem investir em uma marca forte. Se o cliente já teve uma boa experiência com determinado prestador de serviço, tenderá a repetir essa experiência. Assim, lealdade a serviços tende a ser superior que a bens. Outros motivos para maior lealdade a serviços dos clientes são: dificuldade de encontrar alternativas disponíveis, com maior risco associado à mudança (causado pelas próprias características inerentes ao serviço, conforme discutido acima) e custos de mudança tendem a serem maiores em serviços do que para bens.

Entre os custos de mudança o modelo considera: (1) de busca, (2) de transação, (3) de aprendizado, (4) causado pela perda de descontos para clientes leais, (5) vinculados ao hábito do cliente, (6) custos emocionais e (7) custos cognitivos.

Outra maneira de reduzir riscos para o consumidor de serviços é através do uso de fontes pessoais de informação. Por causa da intangibilidade, é difícil explicar a qualidade dos serviços, assim com outras pessoas recomendando, o serviço tem mais relevância para um potencial consumidor do que um anúncio em uma revista, por exemplo.

Em comparação a bens, os clientes de serviço normalmente consideram menos alternativas para compra, pois (1) cada provedor de serviço normalmente só oferece uma marca, (2) número de estabelecimentos que oferecem os mesmos serviços tende a ser menor do que os que oferecem bens e (3) normalmente clientes de serviço não buscam tantas alternativas e informações sobre prestadores diferentes de um mesmo serviço como fazem com bens. 
Por fim, no estágio pré-compra, em comparação a clientes de bens, os de serviço muitas vezes consideram o autoatendimento como alternativa viável ao invés de contratar um serviço.

No estágio de consumo, há uma diferença clara entre o consumo de bens e serviços. Em serviços, devido ao princípio da inseparabilidade, não há uma separação clara das atividades de compra e uso do serviço. Além disso, a atividade descarte do consumo não existe, uma vez que, graças à propriedade da intangibilidade, não há transferência de posse de bens físicos em serviços.

Num estudo de visão integrada do ambiente de serviços ao processo de decisão, Hoffman e Turley (2002) estudaram o papel das variáveis atmosféricas no encontro de serviço e buscaram endereçar a influência destas variáveis no processo de decisão no consumidor de serviços. De forma conclusiva, defendem que muitos encontros de serviço estão se tornando mais baseados nas instalações e menos baseados nas pessoas dado que poucos provedores de serviços estão disponíveis para emprego, o custo do trabalhador sobe e os avanços na tecnologia promovem automação e o surgimento de novos tipos de serviços. Em relação ao processo de decisão dos clientes em serviços, os autores estabeleceram os seguintes achados em relação ao estágio pré-compra:

(1) as variáveis atmosféricas aumentam o número de atributos procuráveis disponíveis para produtos de serviço; assim, diminuem o total de risco geralmente associado com as compras de serviços; (2) conforme o total de informação précompra diminui, os consumidores colocam mais importância nas variáveis atmosféricas ao estabelecer suas avaliações da qualidade do serviço e (3) à medida que aumentam os efeitos prazerosos com o ambiente de serviço, produzidos pelas variáveis atmosféricas, o total de risco geralmente associado com a compra do serviço diminui (HOFFMAN; TURLEY, 2002, p.37).

Para Berry et al. (2002), o conjunto de evidências funcionais e emocionais da experiência influenciará na decisão de compra do serviço. Hoffman e Turley (2002) estabelecem ainda achados relevantes em relação ao estágio de consumo:

(1) as variáveis atmosféricas facilitam a categorização dos encontros de serviços; assim, facilitam a seleção de comportamentos de script adequados e aumentam a probabilidade de sucesso na transação de serviço; (2) variáveis atmosféricas facilitam o fluxo do processo de entrega do serviço pela redução da ambigüidade de papeis; assim, aumentam a eficiência e a eficácia potencial do encontro de serviço e (3) variáveis atmosféricas podem gerir eficazmente clientes que compartilham a mesma experiência de serviço simultaneamente; assim, reduzem eficazmente o total de conflitos entre clientes comumente inerentes aos encontros de serviços (HOFFMAN; TURLEY, 2002, p.38).

A experiência de serviço, portanto, será adquirida por interações com o pessoal de contato/ provedores de serviço, com as evidências físicas e os sistemas da organização. Isso implica 
que a avaliação do serviço prestado ocorrerá tanto durante o consumo como após a compra. Essa característica abre a possibilidade para o profissional de marketing de serviços de detectar problemas e alterar avaliações do serviço de uma forma que um fabricante de bens não possui.

\subsubsection{Gestão do composto de marketing de serviços}

Cada uma das variáveis do mix de marketing é controlável. Segundo Hoffman et al. (2009), quando efetivamente combinado, o mix de marketing pode compensar os efeitos de fatores incontroláveis que existem no ambiente de operações de todas as empresas, como avanços tecnológicos, necessidades do consumidor, novos e antigos concorrentes, leis, condições econômicas e os efeitos da sazonalidade que constantemente alteram o ambiente em que a empresa opera. As empresas que fracassam em alterar sua estratégia de posicionamento para refletir mudanças ambientais, no que se refere a diferenciar a si mesmas das concorrentes, muitas vezes vacilam no longo prazo.

De acordo com Campomar e Ikeda (2006), os 4 P's de marketing ou marketing mix, são considerados controláveis porque cada variável pode ser modificada, ajustada e adaptada por decisões gerenciais. Sobre a origem do conceito, os autores afirmam que a noção de marketing mix, embora tenha sido originada de Neil Borden, em 1949, foi McCarthy quem reduziu as 12 variáveis às 4 clássicas variáveis "produto", "preço", "praça" e "promoção", popularizando o conceito como os “4 P's de marketing”.

Kotler e Keller (2006) defendem que decisões de marketing mix devem ser tomadas para que se exerça influência sobre os canais comerciais, bem como sobre os consumidores finais. Para estes autores, o composto de marketing compreende o conjunto de ferramentas de marketing que a empresa utiliza para perseguir seus objetivos de marketing no mercado-alvo. A ilustração 03 apresenta as principais decisões compreendidas em cada um dos P's do marketing mix. 


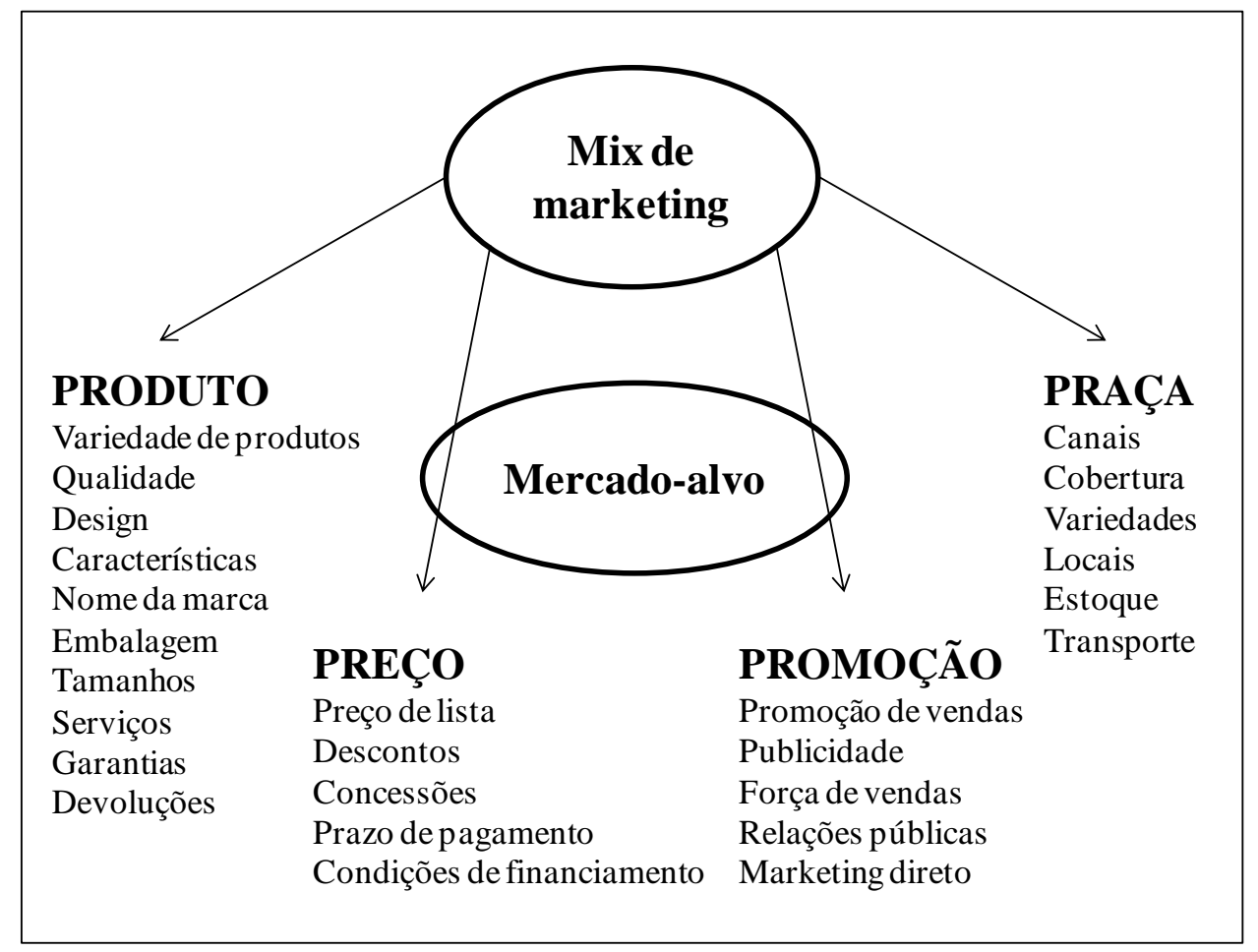

\section{Ilustração 03 - Principais decisões nos 4 P's do mix de marketing}

Fonte: KOTLER; KELLER; 2006, p. 37.

Especificamente no caso de serviços, dadas as características distintivas deste tipo de entrega, sugeriu-se fossem consideradas variáveis adicionais, além dos 4 P's clássicos. Segundo Bitner (1990), devido à característica de inseparabilidade da prestação de serviços, os consumidores frequentemente estão presentes à "fábrica" da empresa e interagem diretamente com o pessoal de atendimento. Assim, a "fábrica" e o pessoal de contato desempenham papeis de marketing da mesma forma em que atendem a funções operacionais. Além disso, considerando a característica de intangibilidade, os consumidores frequentemente procuram por pistas para determinar a capacidade das empresas. Quase sempre as únicas pistas disponíveis acabam sendo as instalações físicas da empresa e seus empregados.

Neste sentido, Booms e Bitner (1981) propuseram um conceito expandido de mix de marketing para as empresas de serviços que considera os 4 P's clássicos de marketing, agregando três novas variáveis: participantes ou pessoas, processos e instalações (em inglês, physical surroundings), assim formando os 7 P's de marketing, para serviços.

- Pessoas: refere-se a todo o pessoal envolvido direta ou indiretamente no consumo de um serviço, por exemplo, empregados ou outros consumidores; 
- Processos: é o sistema de entrega e operação de procedimentos, mecanismos e fluxo de atividades nas quais os serviços são consumidos;

- Instalações ou evidências físicas: relacionam-se com o ambiente em que o serviço é entregue e todos os aspectos tangíveis que auxiliam na comunicação e no desempenho do serviço.

Estas três variáveis influenciam na decisão inicial do consumidor em adquirir um serviço, no nível de satisfação e nas decisões de recompra. Além disso, empresas de serviços dependem fortemente de seus prestadores de serviços para garantir uma experiência de qualidade conforme planejada para seus processos de serviço e servicescape. 


\subsection{Segmentação de mercado, gestão de marcas e posicionamento de marcas}

\subsubsection{Segmentação}

Antes de se seguir com a compreensão do conceito de segmentação em si, é importante entender o contexto em que as empresas estão inseridas no momento em que procuram definir o público-alvo de sua atuação.

Para Weinstein (1995), uma empresa tem duas escolhas estratégicas básicas: segmentar seu mercado ou tratar todo o mercado como consumidores potenciais para seus produtos e serviços, ou seja, praticar uma estratégia de marketing não-diferenciada. De forma complementar, Kotler e Keller (2006) defendem que no marketing de massa o vendedor se dedica à produção, distribuição e promoção em massa de um produto para todos os compradores.

Sobre a serventia da segmentação no processo de marketing, Kotler e Keller (2006) afirmam que, para serem úteis, segmentos de mercado devem ser mensuráveis, substanciais, acessíveis, diferenciáveis e acionáveis e, além, as empresas devem monitorar os interrelacionamentos entre os segmentos, em busca de economias de escopo e de oportunidades de marketing para os supersegmentos.

Em acordo, Hooley e Saunders (1996), apontam três fatores cruciais para o sucesso da adoção da segmentação: os clientes devem diferir uns dos outros em alguns aspectos que poderiam ser usados para dividir o mercado total; os segmentos devem poder ser identificados através de características mensuráveis que possibilitem a estimativa do seu valor potencial como alvo de mercado; e os segmentos selecionados devem poder ser isolados do restante do mercado, possibilitando ser visados com uma oferta de mercado distinta.

Day et al. (1979 apud HOOLEY; SAUNDERS, 1996) defendem a existência de duas premissas básicas para a segmentação de mercado eficaz: o cliente busca os benefícios que os produtos proporcionam e não os produtos em si; e os clientes efetivos e potenciais encaram os agregados de outros benefícios disponíveis de um ponto de vista privilegiado constituído pelos contextos de uso que eles conhecem ou da aplicação específica por eles considerada.

Com uma visão mais ampliada, Mattar et al. (2009), defendem que, dependendo dos recursos da empresa, da homogeneidade do produto, da homogeneidade do mercado, do estágio do 
produto em seu ciclo de vida e das estratégias de marketing da concorrência, pode-se optar por uma dentre três opções estratégicas de atuar em relação aos segmentos de mercado:

1. Estratégia de marketing indiferenciado: compreende a oferta única da empresa para atender a todo o mercado, ignorando as diferenças entre os segmentos, ou constatando que o mercado não é segmentado ou segmentável.

2. Estratégia de marketing diferenciado: compreende a atuação da empresa na maioria dos segmentos de mercado (cobertura ampla);

3. Estratégia de marketing concentrado: compreende o direcionamento dos esforços de marketing da empresa para apenas parte do mercado (concentração em produto e segmento únicos; especialização em linha de produto; especialização no segmento de mercado; ou especialização seletiva em alguns produtos e segmentos específicos)

No quadro 03, Mattar et al. (2009) apresentam a relação entre os fatores condicionantes e as três estratégias de segmentação de mercado.

Quadro 03 - Relação entre fatores condicionantes e estratégias de segmentação

\begin{tabular}{|c|c|c|c|}
\hline $\mathrm{Fatores}^{\text {Estratégia }}$ & $\begin{array}{c}\text { Marketing } \\
\text { indiferenciado }\end{array}$ & $\begin{array}{c}\text { Marketing } \\
\text { diferenciado }\end{array}$ & $\begin{array}{l}\text { Marketing } \\
\text { concentrado }\end{array}$ \\
\hline Recursos & $\begin{array}{l}\text { Recursos limitados e apenas } \\
\text { compatíveis com mercados locais }\end{array}$ & $\begin{array}{l}\text { Recursos disponíveis e suficientes } \\
\text { para serem alocados a diversos } \\
\text { segmentos }\end{array}$ & $\begin{array}{l}\text { Recursos limitados para atender com } \\
\text { eficácia apenas a parte do mercado } \\
\text { total (um ou alguns segmentos) }\end{array}$ \\
\hline $\begin{array}{l}\text { Homogeneidade do } \\
\text { produto }\end{array}$ & $\begin{array}{l}\text { Produtos homogêneos de difícil } \\
\text { diferenciação (gasolina, fósforo, sal, } \\
\text { etc) }\end{array}$ & $\begin{array}{l}\text { Produtos que apresentam } \\
\text { características facilmente } \\
\text { diferenciáveis e ajustáveis a } \\
\text { diferente necessidades e desejos dos } \\
\text { clientes / consumidores }\end{array}$ & $\begin{array}{l}\text { Produtos que apresentam } \\
\text { características facilmente } \\
\text { diferenciáveis e ajustáveis a } \\
\text { diferente necessidades e desejos dos } \\
\text { clientes / consumidores }\end{array}$ \\
\hline $\begin{array}{l}\text { Homogeneidade do } \\
\text { mercado }\end{array}$ & $\begin{array}{l}\text { Mercados homogêneos. Desejos, } \\
\text { necessidades, preferências, etc. dos } \\
\text { consumidores / clientes são idênticos } \\
\text { ou muito assemelhados }\end{array}$ & $\begin{array}{l}\text { Mercados heterogêneos. } \\
\text { Desejos, necessidades, preferências, } \\
\text { etc. dos consumidores / clientes são } \\
\text { suficientemente diferentes para } \\
\text { merecer atendimento diferenciado }\end{array}$ & $\begin{array}{l}\text { Mercados heterogêneos. } \\
\text { Desejos, necessidades, preferências, } \\
\text { etc. dos consumidores / clientes são } \\
\text { suficientemente diferentes para } \\
\text { merecer atendimento diferenciado. A } \\
\text { empresa concentra a atuação em um } \\
\text { oi poucos segmentados em função de } \\
\text { sua limitação de recursos }\end{array}$ \\
\hline $\begin{array}{l}\text { Estágio no ciclo de vida } \\
\text { do produto }\end{array}$ & $\begin{array}{l}\text { Adequada para o estágio de } \\
\text { lançamento para o desenvolvimento } \\
\text { da demanda primária }\end{array}$ & $\begin{array}{l}\text { Adequada para o estágio de } \\
\text { maturidade, quando começam a } \\
\text { aparecer sintomas de saturação e os } \\
\text { clientes / consumidores ficam mais } \\
\text { exigentes }\end{array}$ & $\begin{array}{l}\text { No estágio de crescimento, quando } \\
\text { os esforços de marketing são } \\
\text { concentrados nos segmentos mais } \\
\text { promissores em termos de } \\
\text { crescimento ou retorno }\end{array}$ \\
\hline $\begin{array}{l}\text { Estratégias da } \\
\text { concorrência }\end{array}$ & $\begin{array}{l}\text { Em mercados virgens, é a estratégia } \\
\text { mais adequada. Em mercados em } \\
\text { que a concorrência já está praticando } \\
\text { o marketing diferenciado ou } \\
\text { concentrado, não irá funcionar }\end{array}$ & $\begin{array}{l}\text { Adequada para mercados em que os } \\
\text { concorrentes praticam o marketing } \\
\text { indiferenciado e em mercados em } \\
\text { que os consumidores / clientes já } \\
\text { estão potencialmente segmentados }\end{array}$ & $\begin{array}{l}\text { Adequada para mercados em que os } \\
\text { concorrentes praticam o marketing } \\
\text { indiferenciado ou o concentrado e } \\
\text { existirem segmentos de mercado } \\
\text { ainda inexplorados ou insatisfeitos } \\
\text { com a oferta existente }\end{array}$ \\
\hline
\end{tabular}


Uma definição objetiva para o conceito de segmentação nos traz Silk (2008), segundo o qual a segmentação de mercado consiste em dividir o mercado em grupos de clientes (potenciais) chamados de "segmentos de mercado" - com características, necessidades e comportamentos distintos. Weinstein (1995) acrescenta que nesse processo, ao dividir o mercado em grupos de consumidores potenciais com necessidades e/ou características similares, estes provavelmente, exibirão comportamento de compra similar. Weinstein (1995) defende ainda que o objetivo da pesquisa de segmentação é analisar mercados, encontrar nichos e oportunidades e capitalizar através de uma posição competitiva superior, por meio de programas de marketing únicos para atingir os consumidores potenciais.

Para Silk (2008), o objetivo da segmentação, enquanto processo, é agrupar os clientes em blocos que sejam claramente diferenciados uns dos outros, mas que apresentem um alto grau de homogeneidade interna. Assim, tais segmentos podem ser atendidos de forma mais eficiente e eficaz, com produtos que correspondam a suas necessidades. Neste mesmo entendimento, Weinstein (1995) acrescenta que estratégias de marketing direcionadas à segmentação ajudam a empresa a projetar produtos que atendam eficazmente às necessidades do mercado, a desenvolver táticas e campanhas promocionais eficazes, a galgar posições competitivas e harmonizar as iniciativas de marketing coerentes.

Quanto à forma de se proceder com esta atividade, Weinstein (1995) defende que há muitos métodos alternativos para a segmentação de mercados, sendo que o processo decisório é impactado por fatores racionais e emocionais: demográficos, psicográficos, motivações, necessidades, percepções, hábitos de compra, entre outros.

Propondo uma categorização, para Wind (1978) as variáveis podem ser divididas em dois grupos gerais de características, incluindo no primeiro as demográficas e socioeconômicas, as de personalidade e estilo de vida; e no segundo, as atitudes e o comportamento relativo à mídia de massa e distribuição, além de características do cliente em situações específicas, como padrões de uso de produto e compra, atitudes em torno do produto e seu consumo, benefícios pretendidos numa categoria de produto e qualquer resposta a variáveis específicas de marketing, como novos conceitos de produto, propagandas e afins.

Silk (2008) defende ainda que há dois tipos relacionados de segmentação: a segmentação baseada em benefícios que os clientes buscam (ou seja, a partir de suas necessidades) e a segmentação baseada em características observáveis dos clientes (por ex. demográficas, geográficas, estilo de vida, comportamentais). Para tanto, Silk (2008) propõe a realização do 
processo de segmentação em três passos: entendimento dos benefícios que os clientes buscam; segmentação do mercado e desenvolvimento de perfis prototípicos de clientes, baseados em benefícios; e encontro das variáveis observáveis que têm mais probabilidades de discriminar segmentos específicos.

Para Kotler e Keller (2006), dois grupos gerais de variáveis são usados para segmentar mercados consumidores, que podem ser consideradas isoladamente ou de forma combinada: as características dos consumidores (geográficas, demográficas, psicográficas) e as respostas dos consumidores (atitudes, questões comportamentais). Nesta mesma linha de pensamento, Hooley e Saunders (1996) defendem que as variáveis usadas para segmentar os mercados de consumo podem ser agrupadas em três classes principais:

1. Características básicas do cliente: podem ser classificadas segundo duas dimensões principais, quanto à origem (específicas e não-específicas do marketing) e forma como são medidas (objetivamente ou subjetivamente), conforme quadro a seguir.

\section{Quadro 04 - Características básicas do cliente}

\begin{tabular}{|c|c|c|c|}
\hline & $\begin{array}{l}\text { Medidas } \\
\text { objetivas }\end{array}$ & \multirow{2}{*}{\multicolumn{2}{|c|}{$\begin{array}{c}\text { Relação de } \\
\text { personalidades }\end{array}$}} \\
\hline $\begin{array}{l}\text { Não-específicas } \\
\text { do marketing }\end{array}$ & $\begin{array}{l}\text { Demográficas } \\
\text { Sexo, idade, geografia, } \\
\text { subcultura } \\
\text { Socioeconômicas } \\
\text { Ocupação, renda, } \\
\text { educação }\end{array}$ & & \\
\hline $\begin{array}{l}\text { Específicas } \\
\text { do marketing }\end{array}$ & $\begin{array}{l}\text { Ciclo de vida do } \\
\text { consumidor }\end{array}$ & $\begin{array}{l}\stackrel{\mathscr{v}}{x} \\
\stackrel{2}{2}\end{array}$ & Estilo de vida \\
\hline
\end{tabular}

Fonte: HOOLEY; SAUNDERS; 1996, p. 195.

2. Atitudes do cliente: atitudes frente à classe de produto pesquisada e atitudes frente a marcas no mercado têm sido ambas utilizadas como bases eficazes para a segmentação;

3. Comportamento do cliente: é o método mais direto para a segmentação e abrange compras, consumo, comunicação e a reação a elementos do mix de marketing. 
Por fim, no que toca aos diferentes modelos de segmentação, Weinstein (1995) propõe seis formas: a geográfica, a demográfica e socioeconômica, a de bases psicográficas, a por taxa de uso, a por benefícios e a comportamental. Diferencia ainda a segmentação de mercados industriais e a de mercados internacionais.

Para a empresa que pratica o marketing diferenciado, uma vez definido o modelo de segmentação a seguir, deve-se partir para a seleção dos mercados-alvo em que se pretende atuar. De acordo com Silk (2008), a chave da escolha do segmento de mercado é entender a diferenciação. Ela envolve a coleta e a comparação de dados sobre a empresa e seus concorrentes para avaliar quem tem mais probabilidades de ter sucesso nos segmentos identificados. $\mathrm{O}$ autor recomenda cinco áreas de coleta de dados para o processo, avaliando cada empresa em termos de: capacidade de conceber e projetar; capacidade de produzir (qualidade e quantidade); capacidade de se colocar no mercado; capacidade de financiar; e capacidade de gerenciar / executar.

Para Weinstein (1995) há três opções de seleção de mercados: a diferenciação, em que a empresa projeta duas ou mais estratégias de marketing para atender a segmentos específicos; a concentração, em que se reconhece a diversidade do mercado, mas se escolhe abordar um único mercado-alvo; e a atomização, em que se desenvolvem programas de mercado sob medida para cada cliente potencial-chave.

Já para Kotler e Keller (2006), seriam quatro as formas de se competir em um mercado: marketing de segmento, em que o segmento consiste em um grande grupo de consumidores que possuem as mesmas preferências; marketing de nicho, em que o grupo é definido mais estritamente e procura por um mix de benefícios distintos; marketing local, em que o grupo é formado por clientes locais (áreas comerciais, bairros ou lojas); e customerização, ou também denominado marketing um-para-um, em que o cliente tem autonomia para desenhar o produto e o serviço de sua escolha.

Derivando deste raciocínio, Kotler e Keller (2006) defendem que a empresa deve avaliar cinco padrões de seleções de mercado-alvo, considerando sua atuação em diferentes mercados, com diferentes produtos. Os cinco possíveis padrões de atuação são esquematizados na ilustração 04. 


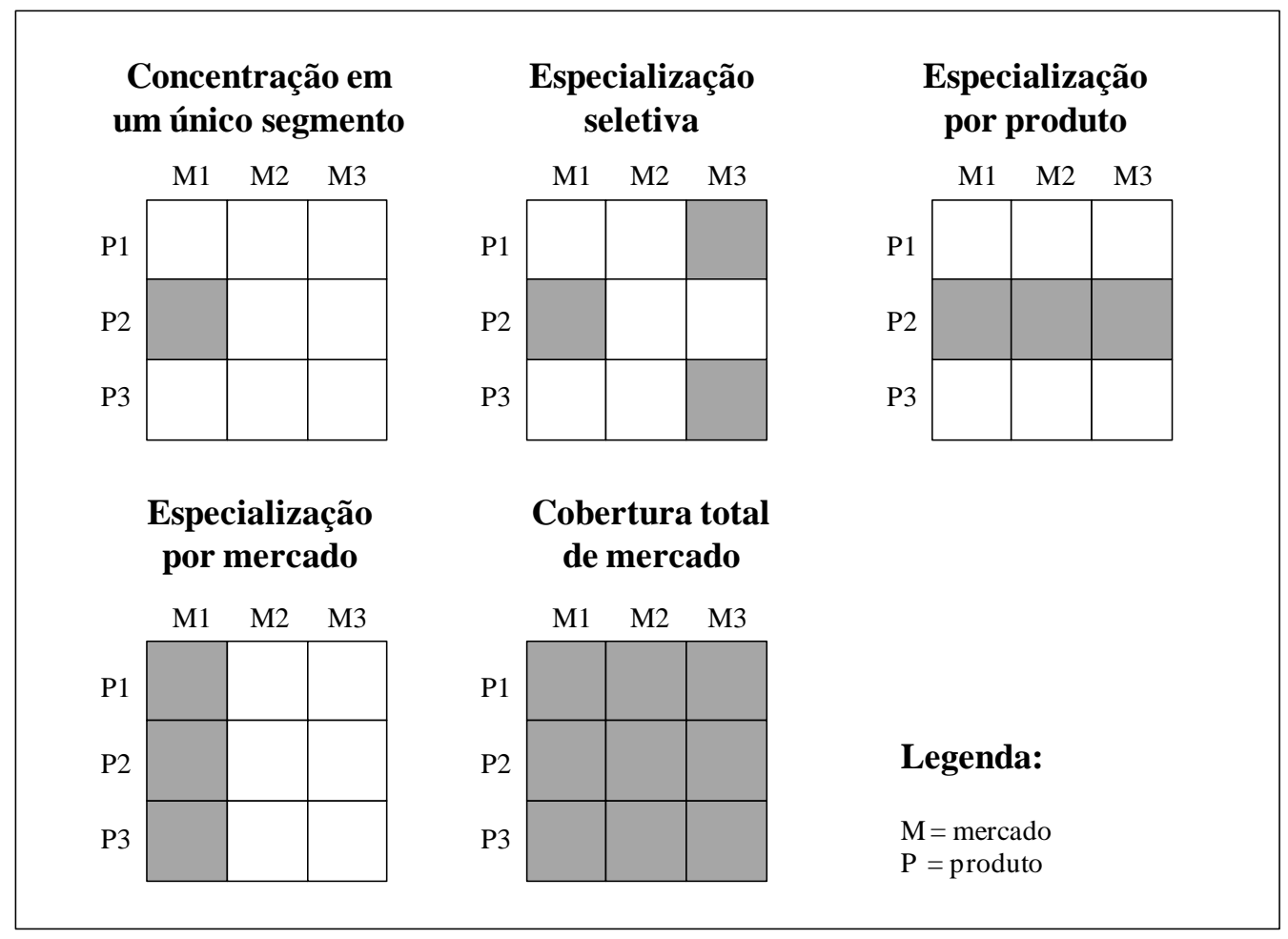

Ilustração 04 - Cinco padrões de seleção de mercado-alvo Fonte: KOTLER; KELLER; 2006, p. 259.

\subsubsection{Gestão de Marcas}

A definição mais atual do comitê de definições da American Marketing Association estabelece que "marca é um nome, termo, desenho, símbolo ou qualquer outra característica que identifica os produtos ou serviços de um fornecedor como distintos de outros fornecedores" (AMA, 2012). Uma marca pode identificar um item, uma família de itens ou todos os itens de um vendedor.

Para Kotler e Keller (2006), uma marca é essencialmente uma promessa da empresa de fornecer uma série específica de atributos, benefícios e serviços uniformes aos compradores. Segundo os autores, uma marca pode trazer até seis níveis de significados, sendo associada a atributos, a benefícios, a valores, a uma cultura, a uma personalidade ou a um determinado grupo de usuários. Por fim, defendem que os significados mais permanentes de uma marca são seus valores, cultura e personalidade, que definem a essência da marca.

A marca é uma maneira de comunicação persuasiva com o consumidor que tem por objetivo influenciar em sua decisão de compra; ela faz uso de símbolos, funções e experiência para descrever o que ele encontrará por trás de uma embalagem. Ela funciona como uma 
consubstanciação da vontade da empresa em garantir à sua clientela, de modo constante e repetitivo, uma combinação de atributos tangíveis e intangíveis, funcionais e hedonistas; ela representa, por parte da companhia, uma tentativa de transmitir uma mensagem de diferenciação e superioridade de seus produtos (FARQUHAR, 1989 apud TURATTI, 2005).

Segundo Kapferer (2003), uma marca não é somente fonte de informações, mas realiza algumas funções típicas, justificando sua atratividade e sua contrapartida monetária, quando é valorizada pelos compradores. $\mathrm{O}$ autor resume em 8 as funções da marca para os consumidores.

Quadro 05 - As funções da marca para os consumidores

\begin{tabular}{|c|c|}
\hline Função & Benefício ao consumidor \\
\hline De referência & $\begin{array}{l}\text { Ver claramente, situar-se em relação à produção setorial, } \\
\text { identificar rapidamente os produtos procurados. }\end{array}$ \\
\hline De praticidade & $\begin{array}{l}\text { Permitir ganho de tempo e de energia na recompra de } \\
\text { produto idêntico pela fidelidade. }\end{array}$ \\
\hline De garantia & $\begin{array}{l}\text { Segurança de encontrar uma qualidade estável em todos os } \\
\text { lugares e a todo instante. }\end{array}$ \\
\hline De otimização & $\begin{array}{l}\text { Segurança de comprar o melhor produto de sua categoria, } \\
\text { com o melhor desempenho para um uso específico. }\end{array}$ \\
\hline De personalização & $\begin{array}{l}\text { Sentir-se reconfortado com sua auto-imagem ou com a } \\
\text { imagem que é passada aos outros. }\end{array}$ \\
\hline De permanência & $\begin{array}{l}\text { Satisfação nascida da familiaridade e da intimidade das ligações } \\
\text { com uma marca que foi consumida durante anos e que ainda dura. }\end{array}$ \\
\hline Hedonista & $\begin{array}{l}\text { Satisfação ligada à estética da marca, seu design e suas } \\
\text { comunicações. }\end{array}$ \\
\hline Ética & $\begin{array}{l}\text { Satisfação ligada ao comportamento responsável da marca } \\
\text { nas suas relações com a sociedade (ecologia, emprego, } \\
\text { cidadania, publicidade não chocante). }\end{array}$ \\
\hline
\end{tabular}

Fonte: KAPFERER; 2003, p. 24.

Uma marca forte deve ter uma identidade de marca clara e valiosa, gerenciada a partir de um conjunto de associações a criar e manter. "A identidade de marca representa aquilo que a empresa deseja que sua marca signifique” (AAKER; JOACHIMSTHALER, 2007, p. 49). Nessa mesma linha, McCracken (apud BATEY, 2010, p. 31) defende que, as marcas são, "em primeiro lugar e acima de tudo, diversos significados. Se não fosse por isso, seria impossível 
falar sobre imagens, personalidades ou posições de marca". Quando criamos as experiências, o objetivo é comunicar os significados.

Mais detalhadamente, Aaker (2008) defende que a identidade da marca é um conjunto exclusivo de associações com a marca que o estrategista de marcas ambiciona criar ou manter. Essas associações representam aquilo que a marca pretende realizar e implicam uma promessa aos clientes, feitas pelos membros da organização. Já o conceito de imagem de marca é apresentado pelo autor como a forma como os clientes e demais pessoas percebem a marca.

Mais que isso, a imagem de marca pode ser definida como "um conjunto de associações, usualmente organizadas de alguma forma significativa" (AAKER, 1996, p. 115). E uma associação de marca estaria então ligada a uma imagem na memória. Para este autor, uma ligação com uma marca será mais forte quando for baseada em muitas experiências ou exposições a comunicações, em vez de em poucas. Neste mesmo sentido, Kapferer (1994) defende que as marcas estão conectadas a um determinado conjunto de associações coerentemente organizadas para transmitir certo significado que, na percepção do consumidor, formam a imagem de marca. E quanto maior for a exposição do consumidor a esse conjunto, mais forte será essa ligação.

Assim, o processo de criação da identidade de marca é algo mais que descobrir o que os clientes dizem querer. Mais que isso, a identidade deverá espelhar também o espírito e a visão da marca, aquilo que ela espera conseguir.

Aaker (2008) define posição da marca como a parcela da identidade e da proposta de valor da marca que deve ser ativamente comunicada ao público-alvo e que apresenta uma vantagem em relação às marcas concorrentes. Neste ponto cabe apresentar objetivamente a distinção entre os conceitos até aqui discutidos:

Quadro 06 - Abstrações de conceitos relacionados à marca

\begin{tabular}{lll}
\hline Imagem da marca & Identidade da marca & Posição da marca \\
\hline $\begin{array}{l}\text { Como a marca é } \\
\text { atualmente percebida }\end{array}$ & $\begin{array}{l}\text { Como os estrategistas } \\
\text { querem que a marca } \\
\text { seja percebida }\end{array}$ & $\begin{array}{l}\text { A parcela da identidade e da } \\
\text { proposta de valor da marca } \\
\text { que deve ser ativamente } \\
\text { comunicada ao público-alvo }\end{array}$ \\
\hline
\end{tabular}

Fonte: AAKER; 2008, p. 76. 
Aaker (1996) entende ainda que "a posição de uma marca" realmente reflete como as pessoas percebem a marca. Contudo, o "posicionamento", ou uma "estratégia de posicionamento", pode ser usado também para refletir como uma empresa está procurando ser percebida. A ilustração 05 apresenta como os conceitos discutidos se relacionam no modelo de planejamento da identidade da marca de Aaker:

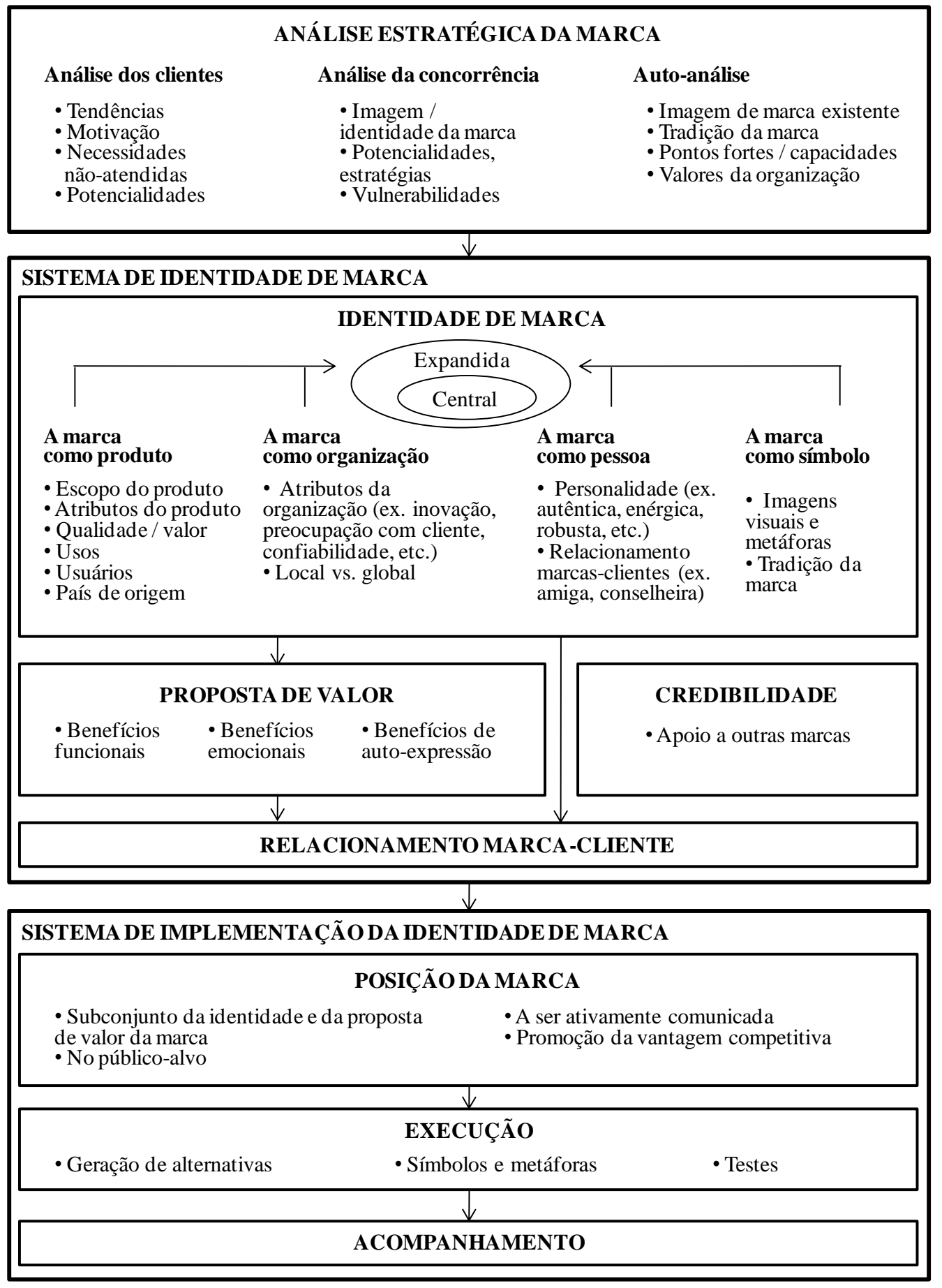

Ilustração 05 - Modelo de planejamento de identidade de marca

Fonte: AAKER; 2008, p. 83. 
Numa visão sistêmica semelhante, mas de forma mais simplificada, Kapferer (2003) defende que a marca não é simplesmente um ator de mercado, ela deve ser um organizador, movido por uma visão, uma missão, uma concepção daquilo que deve se tornar uma categoria. Ao mesmo tempo, executivos em diversas funções além do marketing, tais como finanças, recursos humanos ou operações precisam considerar o impacto de suas ações na marca (BERTHON, 2007).

Kapferer (2003) defende ainda que grandes marcas podem ser comparadas a uma pirâmide, que reflete o sistema da marca. No topo se exprimem a visão e a missão, ou seja, a concepção que a marca tem do produto ou serviço. Esse nível alimenta o nível do tom e dos códigos gerais da marca, que refletem a maneira de ser e de se comunicar da marca. O segundo nível, das características gerais da marca, decorre da visão e entranha-se nos produtos, na divulgação e nas ações da marca. E por fim, no plano dos produtos, a base da pirâmide é aquela dos posicionamentos para cada segmento de mercado.

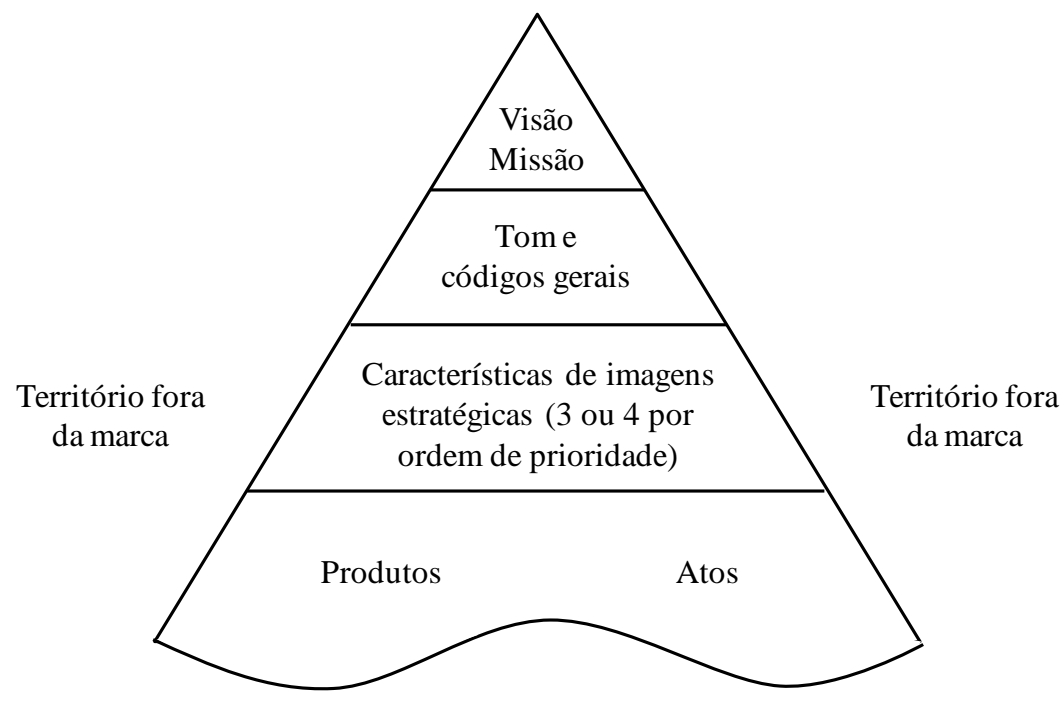

Flutuações permanentes do mercado

Evolução dos consumidores, dos etilos de vida, da concorrência

Ilustração 06 - O sistema da marca

Fonte: KAPFERER; 2003, p. 43.

Keller (1999) defende que o poder da marca é reforçado pelas ações de marketing que consistentemente transmitem o significado da marca para os consumidores em termos de: quais tipos de produto a marca representa; quais os principais benefícios que a marca fornece; quais necessidades a marca satisfaz e como a marca desenvolve produtos e serviços de uma forma melhor. 
Um modelo de como a força da marca se forma é apresentado por Keller e Lehmann (2006), como uma forma tentativa de criar uma noção de "cadeia de valor de marca", estimando diversos elos de relações de causa e efeito ao longo dessa cadeia. O modelo considera quatro grandes etapas relacionadas: "o que as companhias fazem"; "o que os consumidores pensam e sentem"; "o que os consumidores fazem" e "como os mercados financeiros reagem".

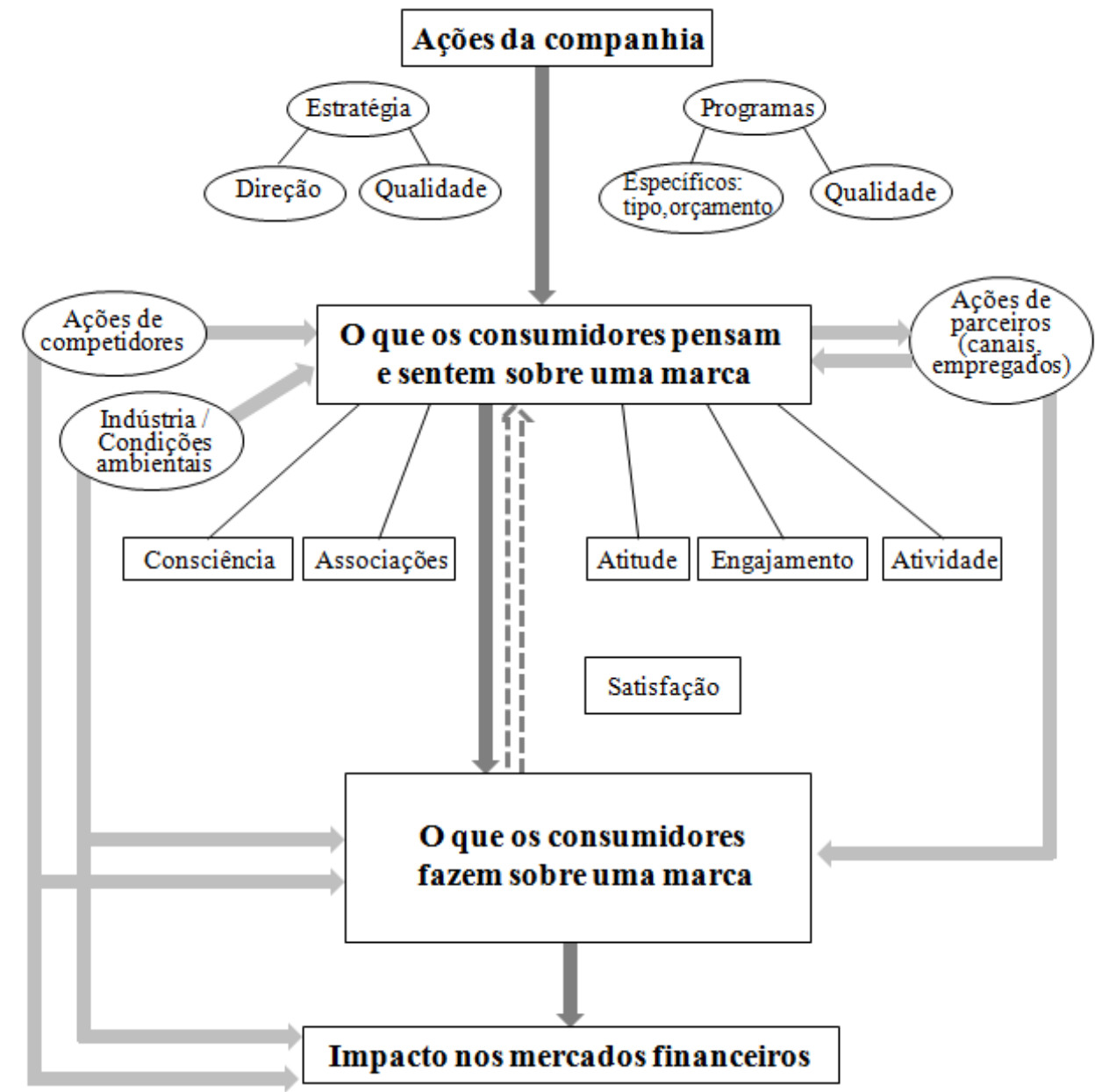

Ilustração 07 - Modelo sistêmico dos antecedentes e consequências da marca Fonte: KELLER; LEHMANN; 2006, p. 756.

De forma complementar, Khauaja e Mattar (2006) sugerem que são inúmeros são os fatores de marketing contribuintes para o sucesso no lançamento e posicionamento de uma marca sólida e estão relacionados a cinco grandes categorias, conforme apresentado na ilustração 08. 
1. Fatores relacionados à informação de marketing

- Compreensão das necessidades funcionais e emocionais dos consumidores

- Conhecimento:

$>$ Do consumidor e dos seu comportamento de compra

$>$ Do mercado e dos concorrentes

$>$ Do posicionamento e das ações dos concorrentes nos segmentos-alvo

$>$ Das forças do ambiente de marketing e detecção de tendências

$>$ Significado da marca para seu público relevante

- Realização de pesquisa de mercado para:

$>$ Tomar decisões estratégicas e táticas a respeito do composto de marketing

$>$ Verificar se a imagem da marca está coerente com sua identidade

$>$ Monitorar a saúde das marcas

$>$ Medir o resultado do investimento na marca

\section{Fatores relacionados à estratégia de marketing}

- Avaliação dos segmentos de mercado

- Definição dos segmentos mais atrativos para si

- Tradução das informações do mercado no mais adequado posicionamento de marca para o consumidor

- Identificação coerente e consistente da marca, ao longo do tempo, com o benefício e com a comunicação com o consumidor

- Identificação coerente da marca com a direção estratégica e a cultura da organização

\section{Fatores relacionados ao composto de marketing}

- Composto de marketing é condizente com a identidade e posicionamento da marca:

$>$ As características do produto ou serviço reforçam a identidade e o posicionamento da marca

> A política de preço é condizente com a estratégia estabelecida para marcar e baseada na percepção de valor dos consumidores

> Os canais de distribuição utilizados são adequados à identidade e ao posicionamento da marca

$>$ A comunicação da marca transmite com eficiência o posicionamento da marca

- Portfólio da marca é condizente com sua identidade

- Desenvolvimento e implementação de várias formas de comunicação da marca de forma sinérgica

- Planejamento e coordenação de todos os pontos de contato da marca com o consumidor, de

forma a garantir a coerência

\section{Fatores relacionados à inovação da marca}

- Pioneirismo (marca chegou ao mercado através de novas tecnologias, novos posicionamentos, novos canais de distribuição, entre outros)

- Inovação (empresa é capaz de reconhecer, avaliar e assimilar novas ideias)

- Atualização (empresa faz atualização e renovação contínuas do produto ou serviço, para que estes fiquem em dia com a tecnologia disponível)

- Adequação (empresa faz a adequação contínua das características do produto ou serviço às necessidades dos consumidores)

\section{Fatores relacionados a recursos aplicados à marca}

- Equipe (ou profissional) de marekting dedicada(o) a gerenciar a marca

- Equipe (ou profissional) de marekting capaz de gerenciar a marca

- Executivos-seniores da empresa envolvem-se na construção e gestão da marca

- Empresa realiza investimentos na marca de forma sólida ao longo do tempo (ex. comunicação, inovação, utilização técnica)

\section{Ilustração 08 - Modelo de planejamento de identidade de marca}

Fonte: Adaptado de KHAUAJA, D.; MATTAR, F. N. Fatores de marketing na construção de marcas sólidas: estudo exploratório com marcas brasileiras. REGE-USP. São Paulo, v. 12, n. 4, out./dez. 2006. 


\subsubsection{Posicionamento}

A definição do conceito de posicionamento, como afirma Telles (2004), pode ser considerada uma tarefa no mínimo arriscada, mesmo para especialistas no assunto. Isso porque posicionamento significa diferentes coisas para diferentes pessoas, e porque os profissionais, de diferentes meios, têm formas diferentes de defini-lo.

Como apontado por Monte (1998), Toledo e Hemzo (1991) traçam uma sinopse do processo evolutivo do posicionamento, resumida nas seguintes contribuições: a) Ries e Trout (1981) apresentaram a ideia do posicionamento como uma ferramenta de apoio ao composto de comunicação; b) este conceito foi modificando-se com as contribuições de outros autores como Wind (1982) e Kotler (1988), que o ampliaram, conferindo-lhe uma dimensão mais abrangente, identificada com o marketing estratégico; c) DiMingo (1988) propõe uma estrutura mais clara para a compreensão do processo de posicionamento estratégico, sugerindo sua divisão em duas fases: posicionamento de mercado (criação de uma vantagem competitiva) e posicionamento psicológico (criação/comunicação de uma identidade distinta).

Para Ries e Trout (2007), o posicionamento começa com o produto, uma peça de merchandising, um serviço, uma empresa, uma instituição, ou uma pessoa. Mas o posicionamento não é o que você faz com o produto, é o que você faz na mente do cliente em perspectiva. "Ou seja, você posiciona o produto na mente do comprador em potencial."

Estes autores encaram o posicionamento como o primeiro sistema de pensamento que enfrenta o difícil problema de se fazer ouvir numa sociedade saturada de comunicação. Afirmam que há produtos demais e propaganda demais, de modo que a mente filtra e rejeita muita informação que lhe chega. Assim, a defesa do indivíduo é uma mente que seja capaz de simplificar consideravelmente as coisas. É neste ponto que os autores justificam a necessidade de as empresas concentrarem-se nas percepções do cliente potencial; e não na realidade do produto.

Ries e Trout (2007) afirmam que o posicionamento baseia-se no conceito de que a comunicação só pode ter lugar no momento certo, na circunstância certa. Assim, o caminho mais fácil para se chegar à mente de uma pessoa é ser o primeiro numa mente que não tenha sido nunca tocada por nenhuma outra marca. Para os autores, os consumidores identificam as marcas em uma espécie de escada de produto na mente. $\mathrm{O}$ conceito, apesar de aparentemente 
simples, faz sentido quando se considera que muitas empresas se engajam em campanhas como se a posição dos concorrentes simplesmente não existisse. Isso porque subir pelas escadas da mente pode ser muito difícil se as marcas de cima estão firmes no lugar.

Assim, de forma geral as empresas devem trabalhar uma categoria de atributo ou benefício que um produto ou uma marca possam possuir, e que sejam convenientes para os consumidores, e, desse modo, tomar a posição de "a número um" nestes atributos. Entre as estratégias alternativas podem se considerar: reforço da posição atual na mente do consumidor, assumir a posição do contra, conquistar uma posição não ocupada, reposicionar a concorrência ou estabelecer um "clube exclusivo".

De maneira geral, Kotler e Keller (2006) definem posicionamento como sendo o ato de desenvolver a oferta e a imagem da empresa para ocupar um lugar destacado na mente dos clientes-alvo. O resultado final do posicionamento é a criação bem-sucedida de uma proposta de valor focalizada no mercado - uma razão convincente para o mercado alvo comprar o produto. O modelo dos autores prevê o desenvolvimento da proposta de valor, por meio da escolha do posicionamento em três estágios: escolha do posicionamento amplo para o produto/serviço; do posicionamento específico para o produto/serviço e do posicionamento de valor para o produto/serviço.

Na primeira etapa, do posicionamento amplo, a empresa define qual a estratégia genérica que a empresa seguirá, que definirá a forma de atuação da unidade de negócios responsável pela criação da oferta ao mercado. Na segunda etapa, as empresas precisam ir além do posicionamento amplo e apresentar a seu mercado um benefício ou uma razão concreta para a compra. Muitas empresas anunciam um posicionamento com um benefício principal, como qualidade, desempenho, confiabilidade, segurança. Por fim, o estabelecimento do preço para a marca determina o posicionamento de valor, sendo possível estabelecer um posicionamento "mais por mais", "mais pelo mesmo", "o mesmo por menos", "menos por muito menos" ou "mais por menos".

Kotler e Keller (2006) defendem ainda que para decidir o posicionamento é preciso determinar uma estrutura de referência e, para tanto, é necessário identificar o mercado-alvo e a concorrência, assim como as associações ideais com a marca no que diz respeito aos pontos de paridade e de diferença. Os pontos de paridade seriam impulsionados pela necessidade de 
pertencer à categoria e pelas necessidades de anular os pontos de diferença dos concorrentes. Os pontos de diferença devem ser considerados desejáveis pelos consumidores e é importante que a empresa os consiga cumprir. Os autores apontam três critérios-chave para que os consumidores os considerem desejáveis, ou seja, devem ter: relevância (importância), distintividade (peculiar e superior) e por fim, credibilidade (plausível e idôneo).

De forma semelhante, segundo Aaker (1996), o posicionamento da marca corresponde à parte da identidade que deve ser ativamente comunicada às audiências. E marcas bem posicionadas são aquelas que ocupam nichos de mercado particulares nas mentes dos consumidores, pela criação de pontos de paridade com a concorrência, bem como pontos de diferenciação, que lhe permitem atingir vantagens sobre essa concorrência.

Aaker e Joachimsthaler (2007) propõem então um modelo de planejamento de identidade de marca em que, após a definição da identidade de marca almejada, procede-se à sua implementação, por meio do posicionamento de marca, que definem como a parte da identidade de marca que será ativamente transmitida ao público-alvo". Sobre este processo complementam ainda:

\footnotetext{
O posicionamento da marca, que deve demonstrar uma vantagem sobre as marcas concorrentes, representa os objetivos atuais de comunicação. Alguns elementos da identidade de marca podem não fazer parte do seu posicionamento pois, embora importantes, não diferenciam entre si. Ou a marca pode não estar pronta para cumprir uma promessa, ou o publico pode não estar preparado para aceitar a mensagem. À medida que a realização dos aspectos mais aspiracionais da identidade de marca se torna viável crível, o posicionamento de marca pode se tornar mais ambicioso (AAKER; JOACHIMSTHALER, 2007, p.52).
}

Para Oliveira (2007) a segmentação do mercado também é uma forma de posicionamento abordagem que deixa claro o estreito relacionamento existente entre essas atividades. Para o autor, talvez essa visão tenha se desenvolvido porque, como o sucesso do posicionamento depende de uma adequada segmentação, esta passou a ser abarcada por aquele.

Outra versão para o desenvolvimento do conceito de posicionamento menos disseminada pela literatura de marketing é trazida por Oliveira (2007), que apresenta Wind (1982): nesta versão, o conceito tem sua origem na teoria microeconômica e teria sido criado para que se pudessem trabalhar as estruturas de mercado, a competição entre empresas e o conceito de substituição entre produtos. Oliveira também apresenta Aaker e Shansby (1982), que concordam em que o posicionamento difere do conceito de imagem, especialmente porque não se restringe a uma visão intrínseca, ou seja, implica um quadro de referência, que são os 
concorrentes. Em acordo com Ries e Trout (2007), Fennel (1978) afirma que o termo posicionamento inclui considerações sobre o produto, mas de forma mais específica em relação ao conteúdo da comunicação.

De forma subjacente, cabe observar que ao se posicionar uma oferta é fundamental a observação de como os clientes atuais e potenciais avaliam as ofertas, e como eles escolhem produtos daquela categoria (TOLEDO; HEMZO, 1991, apud OLIVEIRA et al., 2008).

Palmer e Cole (1995) destacam que os serviços podem ser posicionados isoladamente ou como parte da empresa, além de afirmarem que os consumidores valorizam mais o posicionamento da empresa do que de serviços individuais. Talvez essa consideração se baseie no fato de que, pela própria natureza dos serviços, que implica algum tipo de contato entre "fabricante" e consumidor, torna-se difícil o posicionamento de ofertas específicas, uma vez que haveria necessidade de estruturas empresariais também específicas. Oliveira et al. (2008) defendem que o posicionamento procura estimular uma percepção no público-alvo da oferta, por meio da adequação das suas variáveis aos aspectos por ele valorizados, de forma que a torne distintiva em relação à concorrência.

$\mathrm{Na}$ ampliação desta ideia, Oliveira (2007) apresenta dois outros argumentos de autores distintos: embora Di Mingo (1988) enfatize a importância da comunicação ao apresentar o conceito de posicionamento psicológico, assim como Maggard (1976), dá indícios de que outras atividades e decisões devem ser realizadas e tomadas com vista ao seu sucesso, ao afirmar que o posicionamento é mais do que slogans engenhosos e bem-sucedidas campanhas de comunicação. O verdadeiro posicionamento é o processo de distinguir uma empresa ou produto dos seus concorrentes em dimensões reais - valores corporativos e de produtos que são significativos para os consumidores - para tornar uma empresa ou produto preferido.

De acordo com Aaker e Shansby (1982, apud OLIVEIRA; CAMPOMAR, 2008), para se realizar um posicionamento diversas decisões devem ser tomadas, como a de que segmento de mercado e público-alvo atingir, qual a imagem que se pretende transmitir, e quais as características do produto que serão enfatizadas, entre outras. O posicionamento é uma decisão estratégica porque trabalha com a percepção do consumidor, influenciando o processo de decisão de compra.

McKenna (1989) aborda o posicionamento como uma estratégia, dentro de um plano que ajudará uma dada organização a alcançar uma presença singular de mercado. Nesse processo, 
coloca a necessidade de se examinarem os pontos fortes, as expectativas e as metas da companhia. Em seguida, faz-se necessário comparar as metas da companhia às atitudes, às percepções e às tendências do mercado. Para o autor, com a formação das relações certas uma companhia pode conquistar uma credibilidade e um reconhecimento que jamais conquistaria por meio da publicidade.

A proposta de McKenna (1989) é um modelo de posicionamento dinâmico, segundo o qual as organizações precisam construir fundações sólidas que não sejam destruídas pela turbulência dos mercados, em que produtos, tecnologias, concorrência se modificam numa velocidade cada vez maior. Para o autor, as organizações não deveriam se concentrar em promoções e em publicidade. Precisam compreender a estrutura do mercado, para que depois possam desenvolver relações estratégicas com outras pessoas e com outras companhias de importância vital no mercado. Precisam formar relações com fornecedores, distribuidores, investidores e clientes.

Em seu processo, o posicionamento desenvolve-se gradativamente; inicialmente um produto, marca ou companhia não possui inicialmente nenhum significado real. Mas o seu meio confere-lhe significado e modifica-se quando o meio se modifica. Nesse sentido, o posicionamento dinâmico é um processo multidimensional. Isso porque envolve três estágios interconectados, em que cada qual se baseia no outro e a eles influencia. São eles: o posicionamento do produto, o do mercado e o da empresa; se qualquer um deles falhar, então o processo de posicionamento irá falhar. É dessa forma que a posição sólida ratifica o posicionamento da companhia no mercado e o posicionamento do produto. Assim, fecha-se o círculo do posicionamento competitivo.

Para a definição do conceito de posicionamento, Hooley e Saunders (1996) abordam as questões centrais da estratégia do marketing atual: a identificação do mercado-alvo e a criação de uma vantagem competitiva para atender o mercado escolhido. Tomadas em conjunto, estas decisões constituem o posicionamento competitivo da organização. À medida que os mercados vão ficando cada vez mais congestionados e competitivos e menos previsíveis, aumenta a importância de um posicionamento claro.

Para a criação de uma posição competitiva clara, Hooley e Saunders (1996) estabelecem alguns passos que devem ser realizados, de maneira sistemática, que incluem: a análise do mercado competitivo englobando a definição da finalidade do negócio e a análise da empresa, do cliente e da concorrência; a identificação do mercado-alvo e a criação de uma vantagem 
competitiva. Uma vez que o mercado-alvo tenha sido selecionado, e a diferenciação tenha sido concebida de forma a permitir que a organização sirva àqueles alvos de forma mais efetiva, a implementação da estratégia competitiva desenvolve-se através de estratégias de construção, manutenção, nicho, colheita ou desinvestimento.

De forma mais conclusiva, Serralvo e Furrier (2004), em estudo teórico das orientações em posicionamento, destacam duas correntes básicas: o posicionamento perceptual, ligado às problemáticas de posicionamento de marca e produto; e a orientação organizacional, voltada para a definição do lugar a ser ocupado pela empresa no cenário competitivo. Afirma ainda que essas duas orientações não devem ser consideradas mutuamente excludentes, pois interagem entre si do ponto de vista estratégico e se reforçam, não sendo necessariamente tratadas como esforços separados do ponto de vista dos praticantes de marketing.

Como que ilustrando seu raciocínio, defendem a definição de Alcaniz e López (2000) como a mais próxima dessa visão:

\footnotetext{
O posicionamento da oferta de marketing induz ao marketing mix (preço distribuição, produto e promoção) como fator de sucesso, tem caráter tático/operacional, opera no curto/médio prazos e consideram concorrentes todas as ofertas percebidas como igualmente adequadas a uma situação de uso ou contexto de aplicação. Já o posicionamento estratégico expande a atuação para outros fatores de sucesso do negócio, como a tecnologia, usa um horizonte de longo prazo e emprega um contexto de análise amplo em variedade e quantidade de dimensões estratégicas (ALCANIZ; LÓPEZ, 2000, p.31 apud SERRALVO; FURRIER, 2004, p. 09).
}

Esta ideia permite visualizar o processo de posicionamento praticamente como uma "ponte" entre o organizacional e o perceptual, o estratégico e o operacional, o interno e o externo, a estratégia e o cliente.

Para empresas de serviços, o posicionamento eficaz é, segundo Hoffman et al. (2009), particularmente crítico uma vez que a intangibilidade dificulta a capacidade do cliente para diferenciar uma oferta de serviços de outra. Os autores apontam que o posicionamento em serviços envolve uma combinação estratégica das variáveis do marketing mix da empresa: produto, preço, promoção, praça, instalações físicas, pessoal e processos. A gestão do composto do marketing, ou marketing mix é, portanto, a etapa em que o processo avança e "alcança" o cliente. 
Finalmente, Mattar et al. (2009) resumem diferentes possibilidades de estratégias de posicionamento, no que se refere mais especificamente ao foco da comunicação, conforme exposto no quadro 07.

\section{Quadro 07 - Possibilidades de estratégias de posicionamento}

\begin{tabular}{|c|c|}
\hline Estratégia de posicionamento & Descrição \\
\hline $\begin{array}{l}\text { Posicionamento por atributo único } \\
\text { USP (Unique Selling Proposition) }\end{array}$ & $\begin{array}{l}\text { É enfatizada na comunicação apenas a característica distintiva mais } \\
\text { importante do produto. }\end{array}$ \\
\hline Posicionamento por atributo duplo & $\begin{array}{l}\text { São enfatizadas na comunicação as duas características mais importantes do } \\
\text { produto. }\end{array}$ \\
\hline $\begin{array}{l}\text { Posicionamento por benefício único } \\
\text { USP (Unique Selling Proposition ) }\end{array}$ & $\begin{array}{l}\text { É enfatizado na comunicação o benefício distintivo mais importante do } \\
\text { produto. }\end{array}$ \\
\hline Posicionamento por benefício duplo & São enfatizados na comunicação os dois benefícios mais importantes. \\
\hline Posicionamento por preço-qualidade & $\begin{array}{l}\text { É enfatizado na comunicação o maior valor do produto, ou seja, a melhor } \\
\text { relação preço-qualidade em comparação aos concorrentes. }\end{array}$ \\
\hline Posicionamento racional & $\begin{array}{l}\text { A comunicação enfatiza benefício(s) ou atributo(s) explícito(s) dirigido(s) ao } \\
\text { lado racional da mente do consumidor / cliente. }\end{array}$ \\
\hline Posicionamento emocional & $\begin{array}{l}\text { A comunicação enfatiza benefício(s) ou atributo(s) não explícito(s), visando } \\
\text { provocar reações e associações emocionais favoráveis ao produto; é } \\
\text { dirigido ao lado emocional da mente do consumidor / cliente. }\end{array}$ \\
\hline Posicionamento social & $\begin{array}{l}\text { A comunicação enfatiza, de forma explícita ou implícita, o(s) benefício(s) } \\
\text { social(is) advindo(s) da posse ou uso do produto (estima, status, prestígio, } \\
\text { reconhecimento, aceitação). }\end{array}$ \\
\hline Posicionamento por concorrente & $\begin{array}{l}\text { Pela propaganda comparativa a empresa enfatiza os atributos e benefícios } \\
\text { que o produto tem melhor que o concorrente comparado. }\end{array}$ \\
\hline $\begin{array}{l}\text { Posicionamento por categoria de } \\
\text { usuário }\end{array}$ & $\begin{array}{l}\text { A comunicação é feita e dirigida a uma categoria de usuário e enfatiza que o } \\
\text { produto foi feito para ele, pois atende ao que ele mais procura, associando } \\
\text { uma imediata identificação com o produto. }\end{array}$ \\
\hline
\end{tabular}

Fonte: MATTAR et al.; 2009, p. 198. 


\subsubsection{Segmentação e posicionamento no âmbito do processo de marketing}

Neste ponto, cabe situarmos as estratégias de Segmentação e Posicionamento ao longo do processo de planejamento de marketing. No que se refere ao marketing estratégico, Lambin (1995) defende que o seu papel é orientar a empresa para as oportunidades de mercado mais bem adaptadas aos seus recursos e às suas habilidades, e que tenham um potencial adequado de crescimento e rentabilidade, buscando os seguintes objetivos básicos: (1) identificar opções estratégicas sólidas e claramente definidas; (2) desenvolver sistemas para o acompanhamento do meio ambiente e da concorrência; (3) reforçar a capacidade de adaptação da empresa às mudanças ambientais; (4) prever a renovação da carteira de produtos da empresa.

Neste sentido, Cravens e Piercy (2003) defendem que o marketing estratégico é um processo de desenvolvimento da estratégia orientada para o mercado que leva em conta o ambiente de negócios em constante mudança e a necessidade de entregar um superior valor para o consumidor. Segundo os autores, o foco do marketing estratégico está mais na performance organizacional do que no incremento de vendas.

Nessa visão, o valor superior é entregue pela combinação das estratégias de negócio para influenciar o consumidor a um conjunto integrado de ações orientadas para o mercado. Assim, o marketing estratégico conecta a organização ao meio ambiente e coloca o marketing como uma responsabilidade do negócio como um todo, mais do que uma função especializada.

Valdés (2003) defende ainda que a função do marketing estratégico é orientar a empresa em busca de oportunidades econômicas atrativas para ela, ou seja, completamente adaptadas a seus recursos e a seu "saber fazer", e que oferece um potencial de crescimento e rentabilidade.

O marketing estratégico relaciona-se, portanto, com a identificação e comunicação dos desejos e necessidades dos clientes para a organização; com a determinação do posicionamento competitivo, de modo a ajustar capacidades e competências das empresas às necessidades dos clientes e por fim, por direcionar os recursos da empresa para conseguir satisfação do cliente, por meio da implantação das estratégias.

O modelo da ilustração 09, proposto por Amicci (2004), simplifica e apresenta os componentes do marketing estratégico na entrega de valor para o consumidor. 


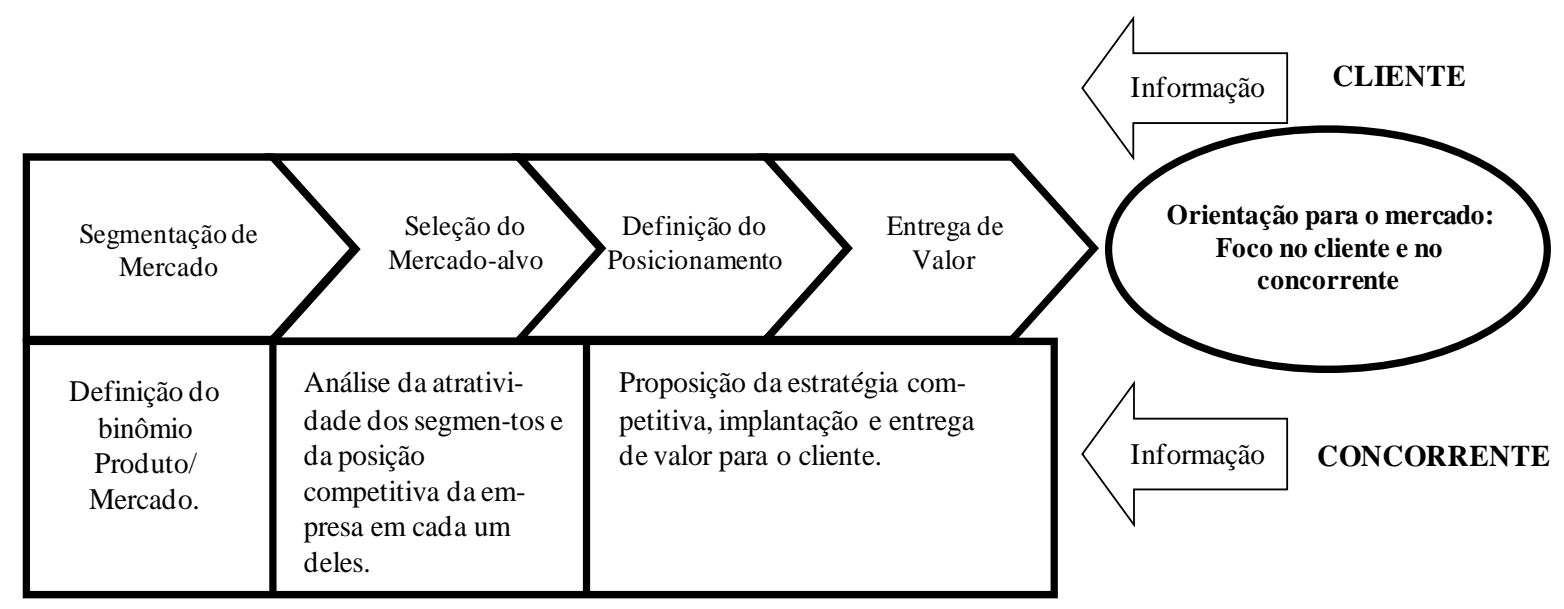

Ilustração 09 - Componentes do marketing estratégico e entrega de valor

Fonte: AMICCI; 2004, p. 22.

E, de forma mais sintética, Cravens e Piercy (2003), sugerem o processo para o marketing estratégico, em 4 grandes etapas:

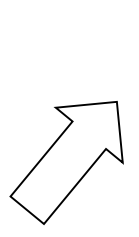

Implementação e gestão da estratégia de marketing

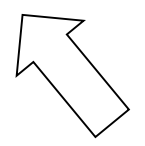

Análise estratégica da situação

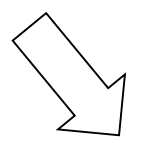

Desenho da estratégia de marketing

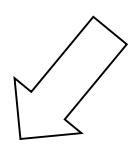

Desenvolvimento

do programa de marketing

Ilustração 10 - O processo de marketing estratégico

Fonte: CRAVENS; PIERCY; 2003

Lambin (1995) defende ainda que a reflexão estratégica da empresa deve se materializar em um programa de ação que defina precisamente os objetivos e os meios de colocar em prática a estratégia de desenvolvimento escolhida. Segundo o autor, em curto prazo, o êxito de uma empresa depende essencialmente do equilíbrio financeiro entre as diferentes atividades em que está envolvida. Mas, em longo prazo, sua sobrevivência e seu desenvolvimento dependem 
de sua capacidade de se antecipar em tempo útil à evolução dos mercados e a modificar, em conseqüência, a estrutura e a composição de sua carteira de atividades.

O esquema da ilustração 11, proposto por Silk (2008), resume de forma bastante objetiva o processo de marketing, com destaque às atividades de Segmentação, Posicionamento e Gestão do mix de marketing como o "centro" do processo em que se cria valor para o cliente. As atividades anteriores (análise do ambiente de marketing) e posteriores (aquisição e retenção de clientes) são igualmente decisivas para o objetivo final de geração de lucro para a empresa.

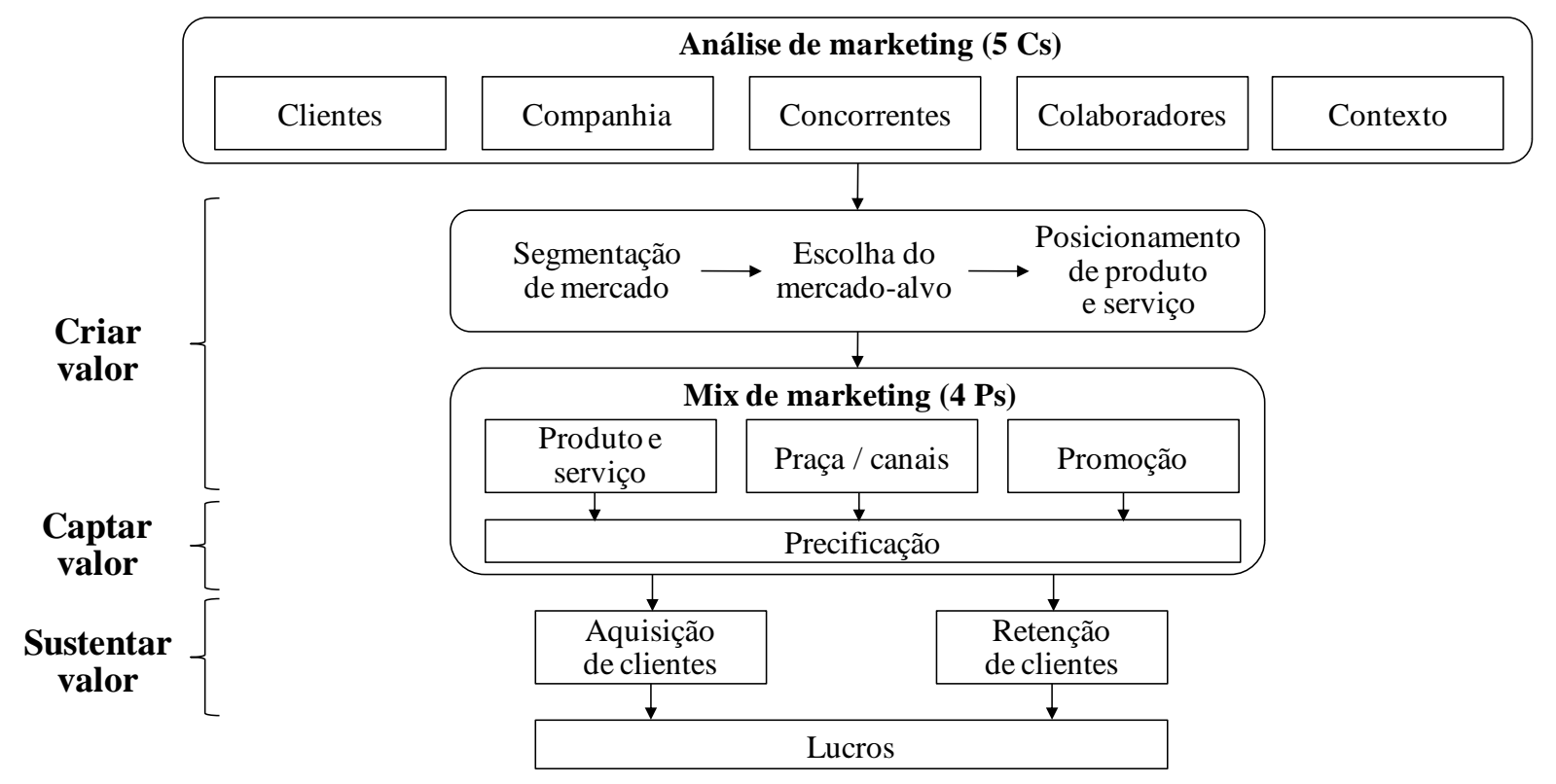

Ilustração 11 - Esquema do processo de marketing Fonte: SILK; 2008, p. 15. 


\subsection{Introdução de inovações disruptivas}

\subsubsection{Conceituação de inovações disrputivas}

De acordo com Kotler e Bes (2011), há três tipos de inovações: marginal ou incremental, radical ou disruptiva e semirradical. A classificação considera duas variáveis: o grau de transformação no modelo de negócios e o uso de tecnologias novas ou preexistentes. Os autores propõem uma matriz com os tipos de inovação, a partir destas duas variáveis.

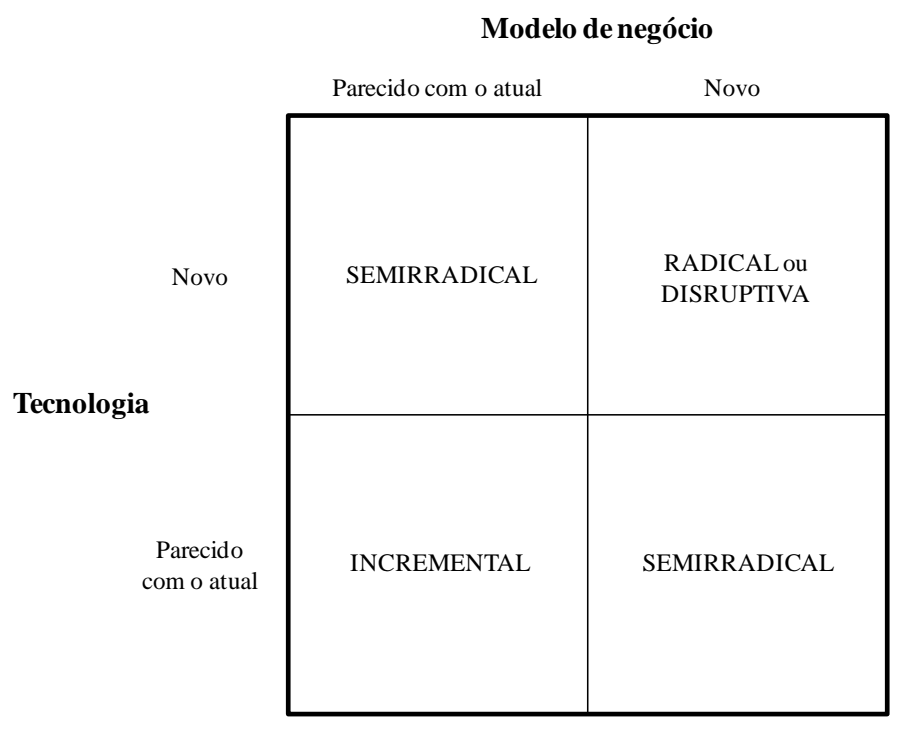

Ilustração 12 - Matriz de tipos de inovação

Fonte: Adaptado de KOTLER; BES; 2011, p. 261.

Entre os três tipos, a inovação incremental envolve o menor risco e, em geral, o menor investimento; a radical, o maior, com a semirradical situada em algum ponto intermediário. Kotler e Bes (2011) defendem que determinar o tipo de inovação é um modo de limitar o nível de risco e, por sua vez, indicar se é desejável mudar tecnologias, modelos de negócios, ambos ou nenhum.

Uma inovação é disruptiva se ela chega para mudar os produtos que a maioria dos consumidores usa. Quão radical uma inovação é depende do nível de diferença entre a tecnologia existente no mercado e a nova inovação. Dado que a inovação altera a forma do produto e sua funcionalidade, novas tecnologias são frequentemente fonte de inovações disruptivas e têm exercido profundo impacto na indústria de serviços (GOVINDARAJAN; KOPALLE, 2006 apud PADGETT; MULVEY, 2007). 
Kotler e Bes (2011) apresentam ainda outra categorização para as estratégias de inovação, que podem ser denominadas como reativas e proativas. As reativas seriam empresas que se concentram muito no curto prazo e, por isso, arriscam-se a perder no longo prazo. Já as proativas procuram moldar o mercado de acordo com os próprios interesses. Por isso, em vez de serem as principais concorrentes no status quo, preferem mudar as regras, e então atuam antes das mudanças do mercado.

Christensen (2000) afirma que a maioria das tecnologias dá suporte à melhoria do desempenho de produtos e que se enquadrariam na categoria de tecnologia incremental, podendo ser descontínua ou caracteristicamente incremental, enquanto outras são de natureza incremental. Ainda para Christensen (2000), ocasionalmente tecnologias de ruptura emergem e trazem inovações que resultam em pior desempenho de produtos, ao menos em curto prazo. $\mathrm{O}$ autor destaca ainda que tecnologias de ruptura trazem a um mercado uma proposição de valor muito diferente daquela disponível até então. Em geral, essas tecnologias têm desempenho inferior aos produtos estabelecidos em mercados predominantes, mas contêm outras características com algumas vantagens adicionais (e geralmente novas) de valor para o cliente. Por fim, produtos baseados nessas tecnologias são geralmente mais baratos, mais simples, menores e frequentemente mais convenientes de usar,

Em trabalho recente, Armenio Neto e Graeml (2010), ao estudar a introdução da inovação disruptiva no mercado de telefonia corporativa apontam estudo de Govindarajan e Kopalle (2006) que fizeram um resumo das características das inovações disruptivas a partir da literatura e levantaram cinco pontos principais:

\footnotetext{
A inovação disruptiva tem um desempenho menor do que o esperado pelos clientes ao ser introduzida; os novos benefícios oferecidos pelas inovações não são valorizados pelos clientes tradicionais; a inovação é mais simples e mais barata; no momento da introdução a inovação atende a clientes sensíveis a preço; e com o tempo as inovações melhoram seu desempenho de forma a atender também às expectativas dos clientes tradicionais (ARMENIO NETO; GRAEML, 2010, p. 10).
}

A introdução da tecnologia disruptiva em um mercado de serviços existente proporciona novas oportunidades para empresas e clientes, frequentemente alterando a natureza do mercado. Consequentemente, novas tecnologias desestabilizam o equilíbrio de mercado, forçando empresas a considerar o papel que a nova tecnologia desempenhará na determinação de novas estruturas de mercado (PADGETT; MULVEY, 2007). 
Esta relação entre a trajetória da necessidade de mercado e a melhoria da tecnologia é ilustrada por Christensen (2000) no gráfico 01.

\section{Gráfico 01 - O impacto da mudança da tecnologia incremental e de ruptura}

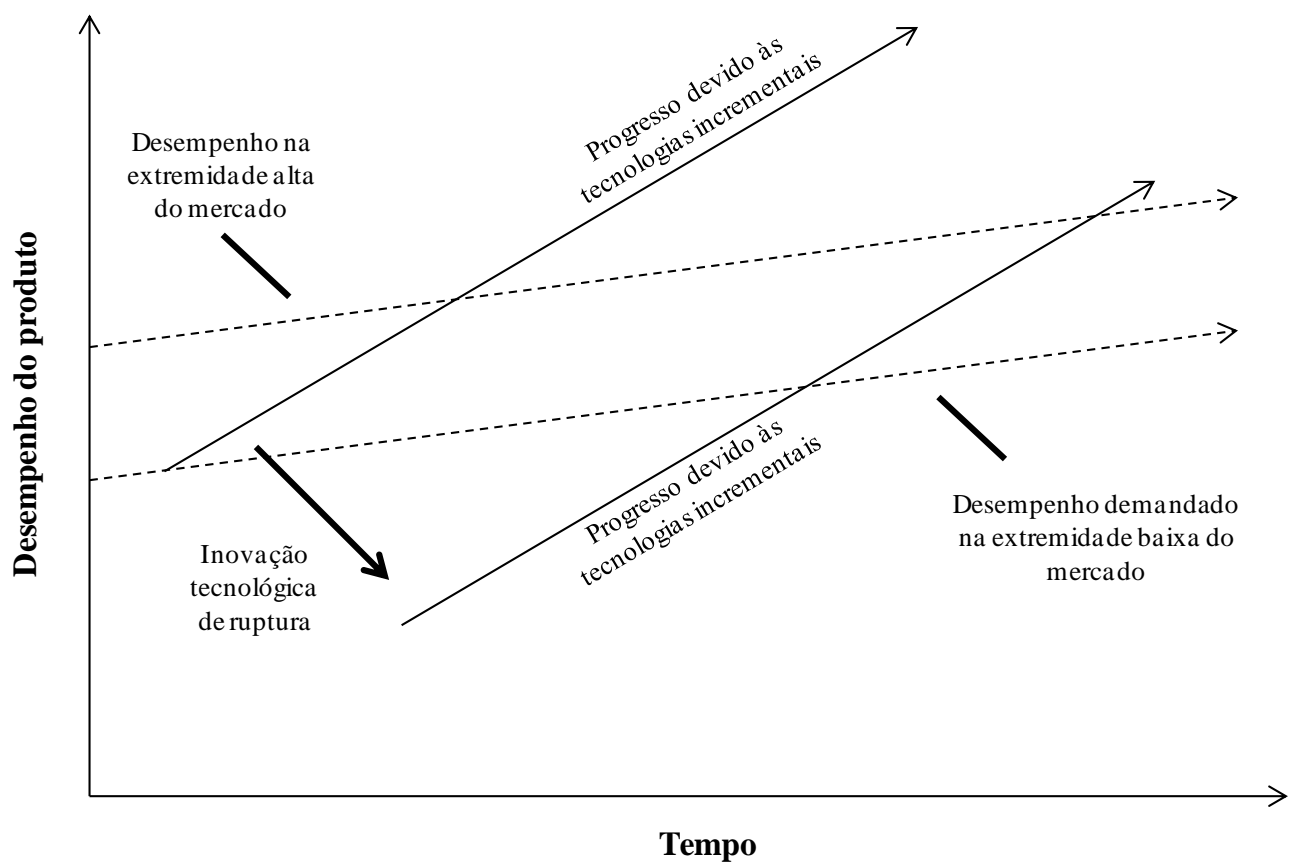

Fonte: CHRISTENSEN; 2000, p. 26.

Segundo Christensen (2000), a observação de que as tecnologias podem progredir mais rápido do que a demanda de mercado significa que, em seus esforços para fornecer melhores produtos do que seus competidores e obter maiores preços e margens de lucro, os fornecedores frequentemente "passam do limite" de seu mercado e oferecem mais do que os clientes necessitam ou estariam dispostos a pagar. Além disso, tecnologias de ruptura podem ter baixo desempenho atual em relação ao que usuários neste mercado necessitam, mas no futuro oferecerão desempenho plenamente competitivo no mesmo mercado.

Podem-se citar como exemplos de introdução de inovação disruptiva aquelas ocorridas nos mercados de fotografia (foto em papel vs. foto digital), informática (computadores desktop vs. computadores laptop), iluminação (lâmpadas convencionais, com bulbo vs. lâmpadas de led), mídias de vídeo (betacam vs. VHS vs. DVD vs. blu-ray).

Percebe-se, portanto, uma aproximação do tema da decisão pela introdução de inovações disruptivas aos critérios da gestão estratégica de marketing, nomeadamente segmentação e posicionamento. Christensen (2000) preocupou-se em explicar porque empresas líderes que 
investem no desenvolvimento de produtos dirigidos a consumidores de alta renda acabam perdendo a posição de liderança na indústria. A visão deste autor, como apresentam Pessoa e Martins (2007), é que as empresas, ao procederem dessa maneira, podem fracassar em algum momento. Com o objetivo de satisfazer os melhores clientes dos principais mercados, firmas líderes tendem a focar exclusivamente tais mercados, investindo primordialmente em tecnologias sustentáveis e negligenciando o investimento em tecnologias disruptivas.

\begin{abstract}
As tecnologias disruptivas, se de imediato geram produtos de pior performance e que não estão à altura de concorrer com os produtos consagrados, com o tempo têm a performance de seus produtos melhorada, o que pode torná-los competitivos também nos principais mercados. A essa altura, é tarde para as firmas líderes investirem em tecnologias disruptivas, acabando elas por perderem a posição de liderança na indústria (PESSOA; MARTINS, 2007, p.324).
\end{abstract}

Este raciocínio se relaciona à adoção de produtos e serviços pelos clientes e traz estreitas implicações para o processo de posicionamento. Segundo Christensen (2000), de início, quando nenhum produto satisfaz o requerimento de funcionalidade, a escolha dos consumidores assenta-se apenas neste critério. Uma vez que um ou mais produtos satisfaçam a demanda do mercado por funcionalidade, o critério de escolha passa a ser o da confiabilidade. Quando esses produtos se apresentam confiáveis, os clientes passam a priorizar o critério de conveniência. Por fim, uma vez que eles atendam ao requisito de conveniência, os clientes devem eleger o fator preço para suas escolhas.

Rosenbloom e Christensen (2005) apud Frontini (2008, p.21) questionam se o impacto da inovação de ruptura está ligado ao sistema produtivo em que ela está inserida, ou ao posicionamento da empresa que adere à inovação perante o sistema de valor. $\mathrm{O}$ valor potencial de uma inovação tecnológica é função do sistema de valor onde a tecnologia será empregada, bem como das relações cliente-fornecedor. Assim, o sucesso de uma inovação de ruptura depende se os atributos de valor e de desempenho serão valorizados no sistema de valor correspondente, ou se a empresa a disseminar a inovação influencia e define incentivos às diferentes oportunidades de negócio que a inovação tecnológica pode vir a trazer.

Para Charitou e Markides (2003), a resposta de uma empresa para a inovação disruptiva estratégica dependerá diretamente da posição da empresa em sua indústria, de suas competências, da taxa à qual a disrupção está crescendo e da natureza do inovador que introduziu a disrupção. Segundo estes autores, no entanto, os dois fatores que mais influenciam são a motivação e a habilidade da empresa em responder eficazmente. 
Padgett e Mulvey (2007) apontam ainda a dificuldade que pode surgir para as empresas, na tomada de decisão em torno do posicionamento a adotar frente à introdução das tecnologias disruptivas. Isso porque podem não ter apelo aos clientes atuais da empresa, sendo mais aplicáveis aos clientes de baixa rentabilidade. Destacam ainda que o posicionamento pode ser desenvolvido por meio de qualquer outro tipo de interação (baseados ou não em tecnologia) ou qualquer outra combinação de interações. De fato, as empresas podem usar diferentes aspectos do processo de serviços - alguns relacionados à tecnologia, outros não - para se posicionar no mercado.

Neste contexto, Tripsas (2003) defende que existem forças que formam a estratégia de comercialização, a partir da mudança tecnológica, e que interferem na forma como a empresa se estruturará e se posicionará perante o mercado. Tais forças, e as respectivas relações com a mudança, são descritas na ilustração 13.

\section{Mudança em tecnologia/ competências}

- Quais são os novos conjuntos de competências necessários para desenvolver e gerir a tecnologia?

- No que eles são diferentes das competências atuais da empresa?

- Que percentual do conjunto de competências atuais da empresa continuará a ter valor quando a nova tecnologia for comercializada?

\section{Mudança nos ativos complementares}

- Quais são os ativos complementares que no momento possuem valor para a empresa?

- Que ativos vão reter seu valor no novo regime tecnológico?

- Quais são os novos ativos complementares exigidos?

- Que padrões de arquitetura de propriedade da empresa, esta pode controlar?

- Com qual produto complementar o produto da empresa agora se depara? Em que área de

produto complementar a empresa deve ingressar?

\section{Mudança nos clientes}

- Quais são os novos segmentos de clientes que surgem com a nova tecnologia?

- No que as necessidades desses clientes diferem dos clientes tradicionais?

- Como a nova tecnologia afeta as capacidades dos atuais clientes?

- Existe uma maneira de suavizar a transição dos clientes e mantê-los com a empresa?

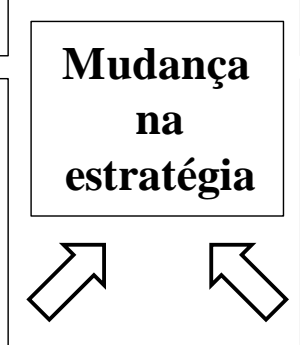

Mudança na concorrência

- Qual é a probabilidade de novos concorrentes de setores diferentes ingressarem nesse mercado?

- No que suas capacidades diferem das dos concorrentes tradicionais?

- No que seus incentivos diferem dos incentivos de concorrentes tradicionais?

Ilustração 13 - Forças que formam a estratégia de comercialização, com a mudança tecnológica Fonte: TRIPSAS, M. Comercializando tecnologias emergentes por meio de ativos complementares. In: DAY, G. S. et al. Gestão de tecnologias emergentes: a visão da Wharton School. 2003, p. 163. 


\subsubsection{Tecnologias de conexão móvel}

A telefonia móvel celular, rotineiramente chamada apenas de celular, deve seu nome à solução tecnológica encontrada para a utilização das frequiências de rádio para transmissão de sinais de voz/dados.

De acordo com o Informe Infra-esturura do BNDES (1997), o sistema de telefonia móvel celular é composto pelos aparelhos celulares, estações rádio-base (ERBs) e centrais de comutação e controle (CCCs). A cada CCC ligam-se diversas ERBs, por meio de cabos ou por radiofreqüência. A cada ERB estão associadas antenas, torres e equipamentos de energia .

O desenvolvimento da telefonia celular se deu em etapas, consistindo, em linhas gerais, no desenvolvimento de tecnologias analógicas e posteriormente, de digitais. A busca de novas tecnologias se deveu, principalmente, à necessidade de aumentar a capacidade de utilização da radiofreqüência concedida para a comunicação celular.

Os padrões de tecnologia de celular podem ser classificados em gerações de sistemas celulares. A classificação desenvolvida pelo site Teleco é apresentada no quadro 08.

Quadro 08 - Gerações de sistemas celulares e respectivas tecnologias

\begin{tabular}{|c|l|}
\hline Geração & \multicolumn{1}{|c|}{ Tecnologias e descrição } \\
\hline $\mathbf{1 G}$ & Sistemas analógicos como o AMPS \\
\hline $\mathbf{2 G}$ & Sistemas digitais como o GSM, CDMA (IS-95-A) ou TDMA IS-136 \\
\hline $\mathbf{2 , 5 G}$ & $\begin{array}{l}\text { Sistemas celulares que oferecem serviços de dados por pacotes e sem necessidade de estabelecimento } \\
\text { de uma conexão (conexão permanente) a taxas de até 144 kbps. É um passo intermediário na evolução } \\
\text { para 3G. Os principais sistemas são o GPRS, EDGE e extensões do CDMA }\end{array}$ \\
\hline $\mathbf{3 G}$ & $\begin{array}{l}\text { Sistemas celulares que oferecem serviços de dados por pacotes e taxas de até 2 Mbps. Os principais } \\
\text { sistemas são o WCDMA e o CDMA 1xEVDO }\end{array}$ \\
\hline
\end{tabular}

Fonte: Site Teleco. Disponível em http://www.teleco.com.br/tutoriais_ana.asp Acessado em 15/09/2012

Sobre a tecnologia analógica utilizada pelo setor de telecomunicações brasileiro no início de sua atuação, Guedes e Vasconcellos (2009), afirmam:

Os sistemas analógicos da primeira geração de telefonia celular foram desenvolvidos para prover serviços de transmissão de voz somente. Dentre eles, destaca-se o sistema Advanced Mobile Phone System (AMPS), adotado pelos Estados Unidos e pela maioria dos países sul-americanos. O sistema analógico possui características estruturais que limitam seriamente seu raio de cobertura geográfica, além de, mesmo com uso de alta potência de transmissão, não atingir razoável capacidade de transmissão de dados (GUEDES; VASCONCELLOS, 2009, p.37). 
Segundo Pereira e Guedes (2004), os padrões de segunda geração baseados em tecnologias digitais de comunicação surgiram no mercado trazendo maior eficiência de utilização do espectro (ou banda de freqüência) e introduzindo novos serviços, não apenas relacionados à voz, mas também à transmissão de dados. No quadro 09 apresenta-se uma breve distinção entre as principais tecnologias de segunda geração:

Quadro 09 - Tecnologias celulares de segunda geração: TDMA, CDMA e GSM

\begin{tabular}{|c|c|}
\hline $\begin{array}{c}\text { TDMA } \\
\text { (Time Division } \\
\text { Multiple Access) }\end{array}$ & $\begin{array}{l}\text { O TDMA é um padrão desenvolvido para aumentar a capacidade de sistemas AMPS } \\
\text { pelo aumento do número de usuários compartilhando o mesmo canal. A utilização de } \\
\text { canais digitais de comunicação entre terminal móvel e ERB permite que até } 3 \text { usuários } \\
\text { compartilhem um mesmo canal pela utilização de diferentes slots de tempo. }\end{array}$ \\
\hline $\begin{array}{c}\text { CDMA } \\
\text { (Code Division } \\
\text { Multiple Access) }\end{array}$ & $\begin{array}{l}\text { O CDMA é um padrão que revolucionou os conceitos empregados na comunicação } \\
\text { entre terminal móvel e ERB. É o padrão dominante nos EUA. No lugar de dividir a } \\
\text { banda disponível em canais que seguem um padrão de reuso de frequiências o CDMA } \\
\text { consegue atingir uma grande capacidade de usuários onde para cada comunicação utiliza } \\
\text { um código de espalhamento do sinal diferente. }\end{array}$ \\
\hline $\begin{array}{l}\text { GSM } \\
\text { (Global System for } \\
\text { Mobile } \\
\text { Communication) }\end{array}$ & $\begin{array}{l}\text { O GSM, originalmente conhecido como Groupe Special Mobile, foi desenvolvido na } \\
\text { Europa para substituir os diferentes padrões analógicos utilizados pelos países europeus que } \\
\text { atuavam numa faixa de frequência específica. É hoje o padrão com o maior número de } \\
\text { usuários em todo o mundo. A capacidade de um sistema GSM é maior que a do AMPS e } \\
\text { menor que um sistema TDMA. Em relação ao TDMA e ao CDMA, tem o diferencial de } \\
\text { uso de chips para funcionamento do celular, permitindo o fácil intercâmbio entre diversos } \\
\text { aparelhos celulares. }\end{array}$ \\
\hline
\end{tabular}

Fonte: Adaptado do site Teleco. Disponível em http://www.teleco.com.br/tutoriais_ana.asp Acessado em 15/09/2012

O caminho de evolução tecnológica com vistas às gerações tecnológicas posteriores, nomeadamente $3 \mathrm{G}$ e $4 \mathrm{G}$ dependem da infraestrutura existente na segunda geração. Os padrões GSM e CDMA apresentam formas diferentes de evolução para evolução às gerações 3G e 4G. Estes “caminhos” tecnológicos são apresentados no diagrama da ilustração 14.

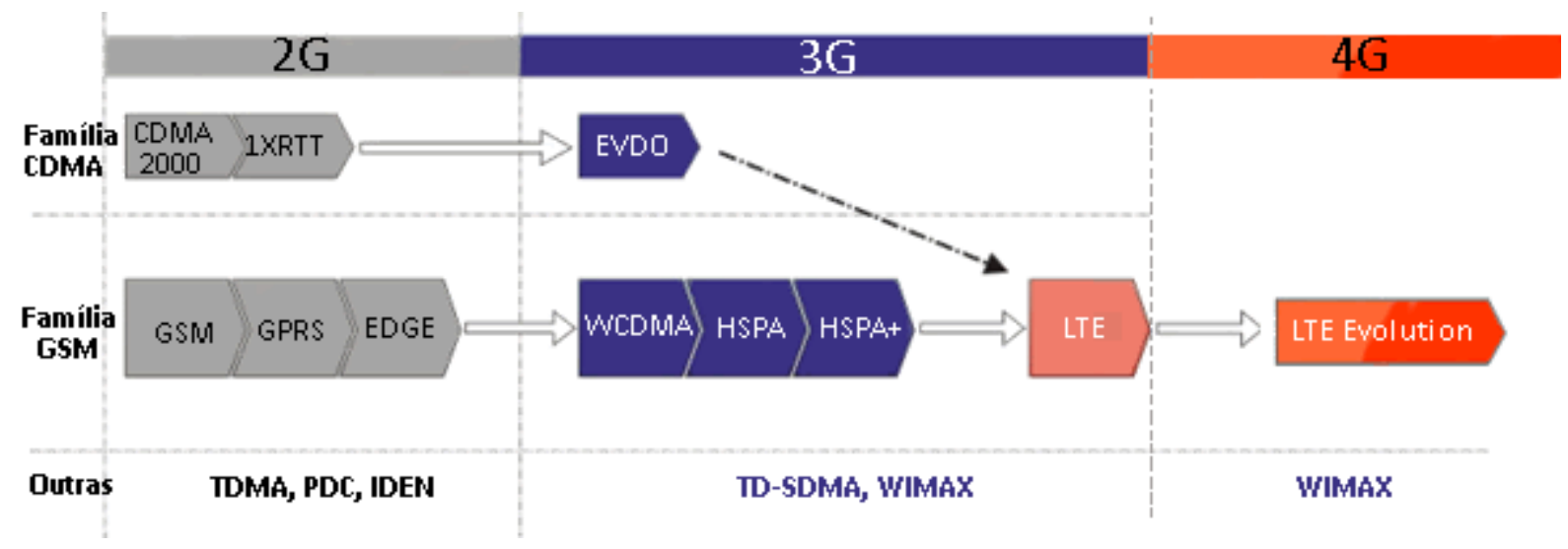

Ilustração 14 - Evolução tecnológica das famílias CDMA e GSM

Fonte: Site Teleco. Disponível em http://www.teleco.com.br/tecnocel.asp Acessado em 15/09/2012 
Do ponto de vista prático, as diferenças entre as gerações tecnológicas se refletem na experiência do usuário do serviço de telefonia celular, conforme exposto por Pereira e Guedes (2004).

Tecnologia 2G
A tecnologia da maioria
dos telefones móveis
digitais
Facilidades:
- Chamadas telefônicas
- Caixa Postal
- SMS
Velocidade de
Transmissão: $10 \mathrm{Kbps}$
Tempo para download
de uma música MP3 de
$\mathbf{3}$ minutos: $31-41$ min

\begin{tabular}{l|l|}
\hline & Tecnologia 3G \\
\hline & $\begin{array}{l}\text { A melhor tecnologia } \\
\text { disponibilizada } \\
\text { Tecnologia 2,5G }\end{array}$ \\
\hline A melhor tecnologia & Facilidades: \\
disponibilizada & - Chamadas telefônicas \\
atualmente & - Fax \\
Facilidades: & - Caixa Postal \\
- Chamadas telefônicas & - SMS/ E-mail \\
- Fax & - Roaming Global \\
- Caixa Postal & - Acesso a Internet em \\
- SMS/ E-mail & alta velocidade (Web) \\
- Acesso a Internet & - Serviços de \\
- Serviços de & localização \\
localização & - Videoconferência \\
Velocidade de & - TV por assinatura \\
Transmissão: & Velocidade de \\
64-144Kbps & Transmissão: \\
Tempo para download \\
de uma música MP3 de \\
3 minutos: 6-9 min
\end{tabular}

\section{Ilustração 15 - Descrição e facilidades das gerações de tecnologia celular} Fonte: PEREIRA; GUEDES; 2004, p. 29.

\subsection{Setor de serviços de telecomunicações no Brasil}

De acordo com Sbragia e Galina (2004), a reestruturação do setor de telecomunicações brasileiro iniciou-se em 1995, com a quebra do monopólio, a abertura da telefonia celular, a criação da agência reguladora em 1997 e a promulgação da Lei Geral de Telecomunicações (9.472/97), seguida da privatização das empresas em 1998 e da introdução da competição através das empresas "espelhos".

Especificamente, o ano de 1998 constituiu-se em marco para a história das telecomunicações brasileiras: o Sistema Telebrás foi privatizado em 29 de julho. O processo de transformações tivera início com a mudança da Constituição Federal e prosseguira com a promulgação da Lei Mínima e da Lei Geral de Telecomunicações (LGT), em 16 de julho de 1997, que criava e implementava o órgão regulador, a Agência Nacional das Telecomunicações (ANATEL) e aprovava o Plano Geral de Outorgas, o Plano Geral de Metas e a reestruturação do Sistema Telebrás, culminando com a venda das ações de propriedade da União (NEVES, 2002; QUINTELLA; COSTA; 2009).

Os quatro grandes processos implementados pelo governo federal com vistas a efetivar a reestruturação dos serviços foram: 
- A implantação da telefonia móvel da banda B,em 1997, quando o território nacional foi dividido em dez áreas de concessão;

- A privatização do Sistema Telebrás, em 1998, quando a telefonia fixa ficou dividida em três áreas de concessão, a longa distância se concentrou numa só operadora e a telefonia móvel da banda A se repartiu entre dez áreas;

- A criação e concessão, em 1999, das empresas-espelhos de telefonia fixa e de longa distância;

- A implantação da telefonia móvel nas bandas C, D e E, que formaram a segunda geração do segmento do país, denominada Serviço Móvel Pessoal (SMP).

O principal objetivo da reestruturação do setor era "atrair investimentos estrangeiros para instalar no país uma moderna infraestrutura de telecomunicações e reduzir a lacuna entre oferta e demanda dos serviços existentes no mercado nacional" (FRONTINI, 2008, p.54).

Neste sentido, Neves (2002) afirma que o setor de telecomunicações pode ser dividido em quatro grandes segmentos: Serviço Telefônico Fixo Comutado, Serviços de Telefonia Móvel, Serviços de Comunicação de Massa (radiodifusão e TV por assinatura) e Serviços Multimídia (comunicação de dados, linha dedicada).

Fransman (2001) representa a indústria contemporânea de telecomunicações por meio de um modelo composto por seis camadas interdependentes, em que a camada superior faz uso de serviços e infraestrutura fornecidos pelas camadas inferiores. O modelo, apresentado na ilustração 16, auxilia no entendimento das fronteiras dos setores e nessa visão, o setor de telecomunicações está restrito às camadas 1 e 2 ; o setor de informática às camadas 3 e 4 e o de mídia tradicional às camadas 5 e 6. 


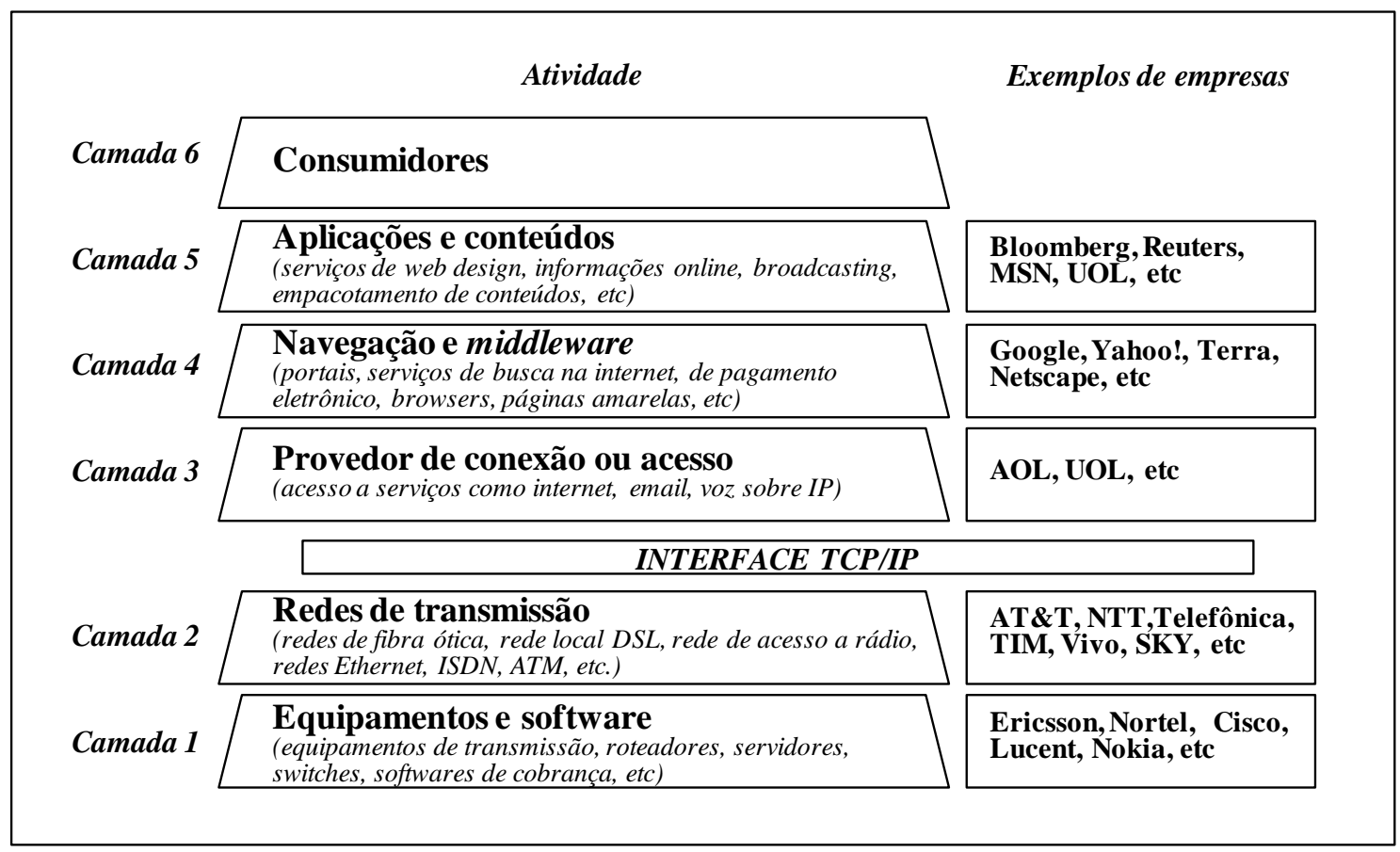

\section{Ilustração 16 - Modelo de camadas da Indústria de Infocomunicação Fonte: Adaptado de FRANSMAN; 2001, p. 95.}

Conforme analisa Frontini (2008), o modelo permite visualizar a organização dos setores econômicos e possíveis especializações, integração vertical ou horizontal; também permite localizar onde se encontram os esforços em P\&D e as barreiras de entrada no setor econômico.

Para Guedes e Vasconcellos (2009), a privatização possibilitou a formação de operadoras entrantes, fomentando um cenário de competição que elevou substancialmente a oferta, disponibilidade e qualidade dos serviços prestados à população. As operadoras de telefonia fixa e celular desempenham papel central como agentes propulsores da cadeia que desenvolve e oferece inovações tecnológicas no setor. Novas formas de relacionamento entre cliente e empresa foram estabelecidas e o envolvimento do consumidor com a avaliação do serviço de telecomunicação passou a ser cada vez mais relevante. A concorrência entre empresas num mesmo mercado consumidor aumentou e questões como marca, posicionamento e oferta tornaram a atividade do profissional de marketing do setor mais desafiadora.

Guedes e Vasconcellos (2009) defendem que o uso da telefonia celular em larga escala gera impactos sociais importantes, pois na medida em que os usuários incorporam as funcionalidades deste meio de comunicação ao seu cotidiano, a ausência, mesmo que momentânea dessas facilidades é fonte de grande frustração. 
No passado, o telefone celular já foi considerado um objeto de luxo, um bem valioso, raro e escasso. Após a privatização, com a popularização do serviço, principalmente com a introdução do serviço pré-pago, em 1998, o celular passa a se tornar inclusive uma alternativa à telefonia fixa, para pessoas de todas as classes sociais, trazendo para as marcas diversos perfis de clientes.

\begin{abstract}
Além disso, outros aplicativos disponíveis no próprio aparelho celular contribuem para o aumento da produtividade, tais como GPS para localização na cidade ou rastreamento de veículos; agenda de compromissos e contatos sincronizada com a estação de trabalho, telefonia via Internet, processadores de texto, leitura e edição de planilhas de cálculo, dispositivo para armazenamento de dados, entre outros. $\mathrm{O}$ acesso aos aplicativos on line, em qualquer momento ou lugar da área de cobertura, define o paradigma "qualquer coisa, a qualquer hora, em qualquer lugar" (SADLER et al., 2006), que traz decorrências diversas para a sociedade e desafia as operadoras a manterem uma infraestrutura complexa e de altíssima disponibilidade (GUEDES; VASCONCELLOS, 2009).
\end{abstract}

A privatização do setor em 1998 previu de três a quatro empresas por área de concessão, a fim de assegurar a competitividade e investimento do setor, o que trouxe ao mercado em torno de 24 operadoras móveis. Com a desregulamentação do mercado a partir de 2002, iniciou-se um movimento de consolidação nacional, resultando na presença atual de quatro grandes operadoras em âmbito nacional: Vivo, Claro, TIM e Oi (FRONTINI, 2008, p.56).

Com o tempo, o mercado baseado na aquisição de novos clientes (que não possuíam telefone celular) se transformou num mercado de captação de clientes da concorrência, sobretudo os de maior valor: os clientes pós-pagos. Isso provocou grande movimentação no sentido de fidelizar a base de clientes (SATO, 2010, p. 59).

\title{
2.4.1 Áreas de atuação e bandas de freqüência das operadoras celulares
}

Como define o site Teleco, as operadoras de Banda A e B possuíam originalmente permissões para o Serviço Móvel Celular (SMC) e migraram para o SMP (Serviço Móvel Pessoal). O SMP dividiu o Brasil em 3 regiões, mas a distribuição de bandas de frequência utilizadas pelas operadoras está mais próxima das 10 áreas de prestação de serviço definidas pelo antigo SMC.

Assim, percebe-se o "mosaico" formado ao se considerar as áreas de atuação e a banda de freqüência, que é o intervalo ou faixa de frequiência utilizada pelas operadoras para a realização da prestação do serviço e que interfere principalmente na questão de portfólio tecnológico com o qual a operadora irá lidar. Os mapas apresentados nas ilustrações 17 e 18 
fornecem uma visão consolidada das regiões e áreas em que o país foi dividido para concessão das bandas de frequiência às operadoras fixas e celulares que passaram a prestar o serviço de telecomunicações.

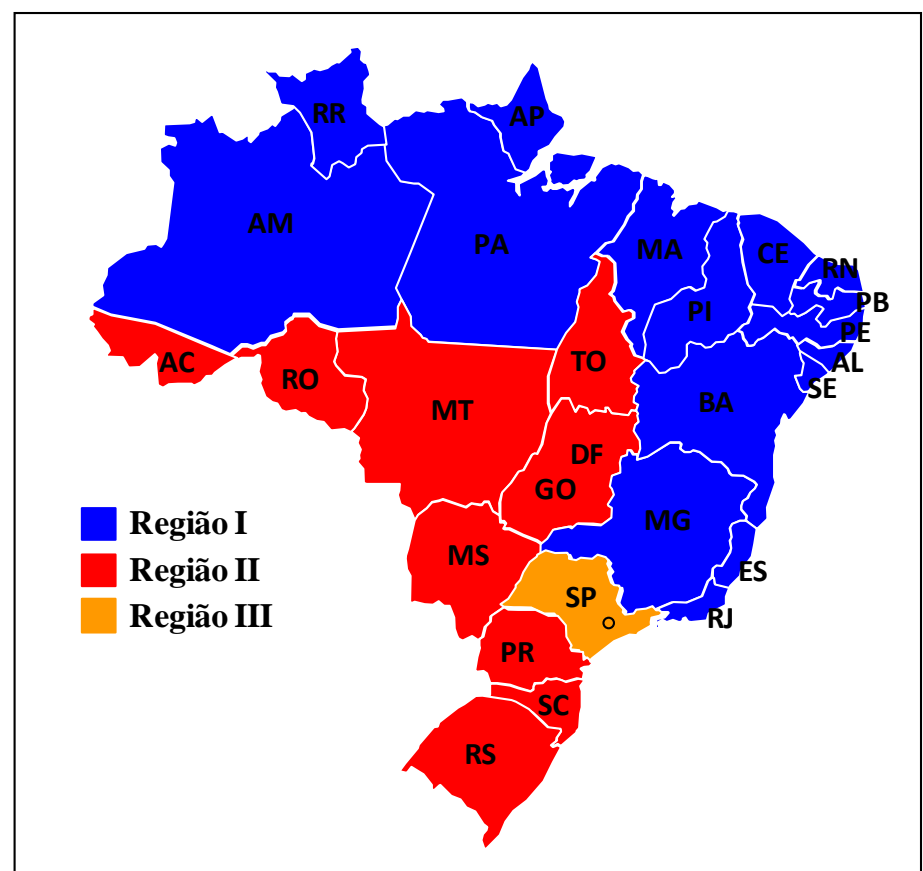

Ilustração 17 - Regiões do SMP (Serviço Móvel Pessoal)

Fonte: Adaptado do site Teleco. Disponível em http://www.teleco.com.br/areasc.asp Acessado em 10/08/2012.

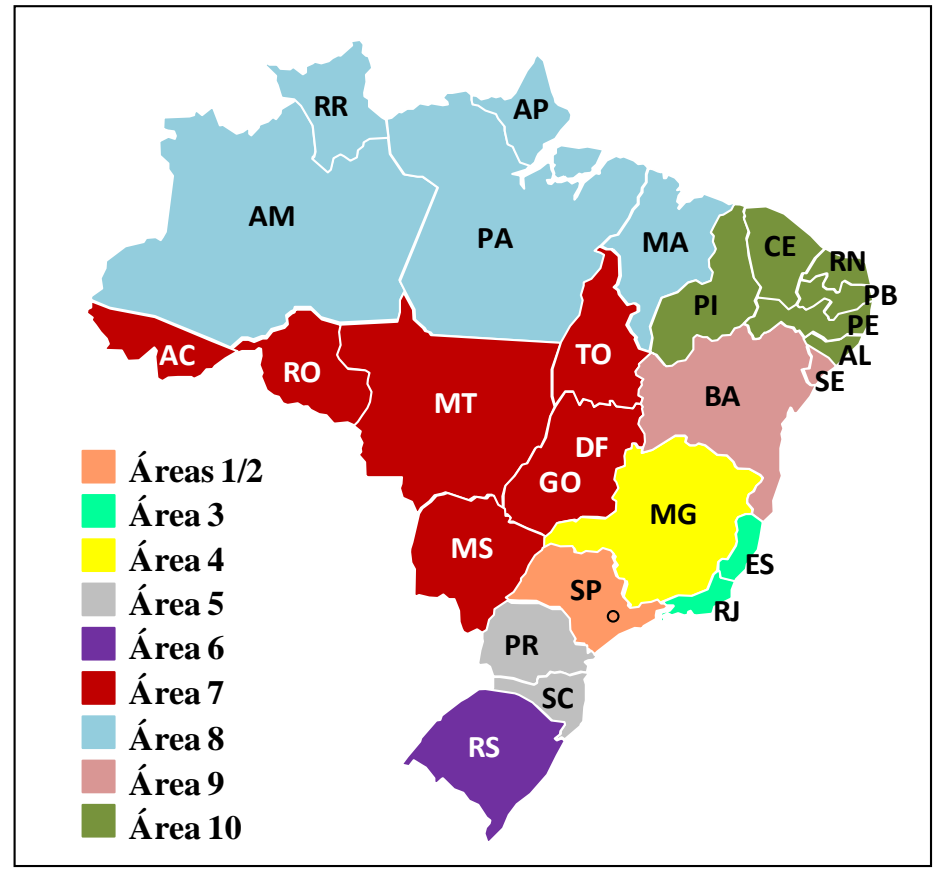

Ilustração 18 - Áreas do SMC (Serviço Móvel Celular)

Fonte: Adaptado do site Teleco. Disponível em http://www.teleco.com.br/areasc.asp Acessado em 10/08/2012. 
O quadro 10 resume a divisão das operadoras de celular nas áreas de atuação e as bandas de freqüência em que prestam o serviço em cada área.

Quadro 10 - Relação de operadoras celulares por banda de frequência e área de serviço

\begin{tabular}{|c|c|c|c|c|c|c|c|}
\hline \multirow{2}{*}{\multicolumn{2}{|c|}{$\begin{array}{l}\text { Frequência } \\
\text { Área SMC }\end{array}$}} & \multicolumn{2}{|c|}{$850 \mathrm{MHz}$} & \multicolumn{3}{|c|}{$1800 \mathrm{MHz}$} & \multirow{2}{*}{$\begin{array}{c}1900 \mathrm{MHz} \\
\text { Banda L }\end{array}$} \\
\hline & & Banda A & Banda B & Banda D & Banda E & Banda M & \\
\hline 1 & SP 11 & Vivo & Claro & Tim & Unicel & Oi & Vivo \\
\hline 2 & $\begin{array}{l}\text { SP Interior } \\
\text { Franca (1) }\end{array}$ & $\begin{array}{c}\text { Vivo } \\
\text { CTBC }\end{array}$ & Claro & Tim & Oi & Oi & Vivo \\
\hline 3 & RJ/ES & Vivo & Claro & Oi & Tim & Nextel & Vivo \\
\hline 4 & $\begin{array}{l}\text { MG } \\
\text { Uberlândia (2) }\end{array}$ & $\begin{array}{l}\text { Vivo } \\
\text { CTBC }\end{array}$ & Tim & Oi & $\begin{array}{l}\text { Claro } \\
\text { Vivo }\end{array}$ & Nextel & - \\
\hline 5 & $\begin{array}{l}\text { PR/SC } \\
\text { Londrina (3) }\end{array}$ & $\begin{array}{l}\text { Tim } \\
\text { Serc. }\end{array}$ & Vivo & $\begin{array}{c}\text { Claro } \\
\text { Tim }\end{array}$ & $\mathrm{BrT}$ & Vivo & $\begin{array}{l}\text { Vivo } \\
\text { Claro }\end{array}$ \\
\hline 6 & $\begin{array}{l}\text { Rio G. do Sul } \\
\text { Pelotas (4) } \\
\end{array}$ & $\begin{array}{l}\text { Vivo } \\
\text { Tim } \\
\end{array}$ & Claro & $\begin{array}{c}\text { Tim } \\
\text { Vivo } \\
\end{array}$ & $\mathrm{BrT}$ & Vivo & Vivo \\
\hline 7 & $\begin{array}{l}\text { C. Oeste } \\
(5)\end{array}$ & $\begin{array}{l}\text { Vivo } \\
\text { CTBC }\end{array}$ & Claro & Tim & $\mathrm{BrT}$ & $\begin{array}{l}\text { Vivo } \\
(6)\end{array}$ & Vivo \\
\hline 8 & Norte & Claro & Vivo & Oi & Tim & Nextel & Claro \\
\hline 9 & BA/SE & Vivo & Tim & Oi & Claro & Nextel & Vivo \\
\hline 10 & Nordeste & Tim & Claro & Oi & Vivo & Nextel & Vivo \\
\hline \multicolumn{8}{|c|}{$\begin{array}{l}\text { Notas: (1) SP Interior exclui Franca e municípios do setor 33, (2) MG exclui Uberaba, Uberlândia e municípios do } \\
\text { setor 3, (3) PR/SC exclui Londrina e Tamarana, (4) Rio G. do Sul exclui Pelotas e municípios do setor 30, (5) C. Oeste } \\
\text { exclui Paranaíba (MS) e municípios do setor } 25(G O) \text {. }\end{array}$} \\
\hline
\end{tabular}

Fonte: Adaptado do site Teleco. Disponível em http://www.teleco.com.br/areasc.asp Acessado em 10/08/2012.

Os mapas da ilustração 10 apresentam, para cada uma das 4 grandes operadoras celulares, as bandas de freqüência em que atuam em cada Estado brasileiro.

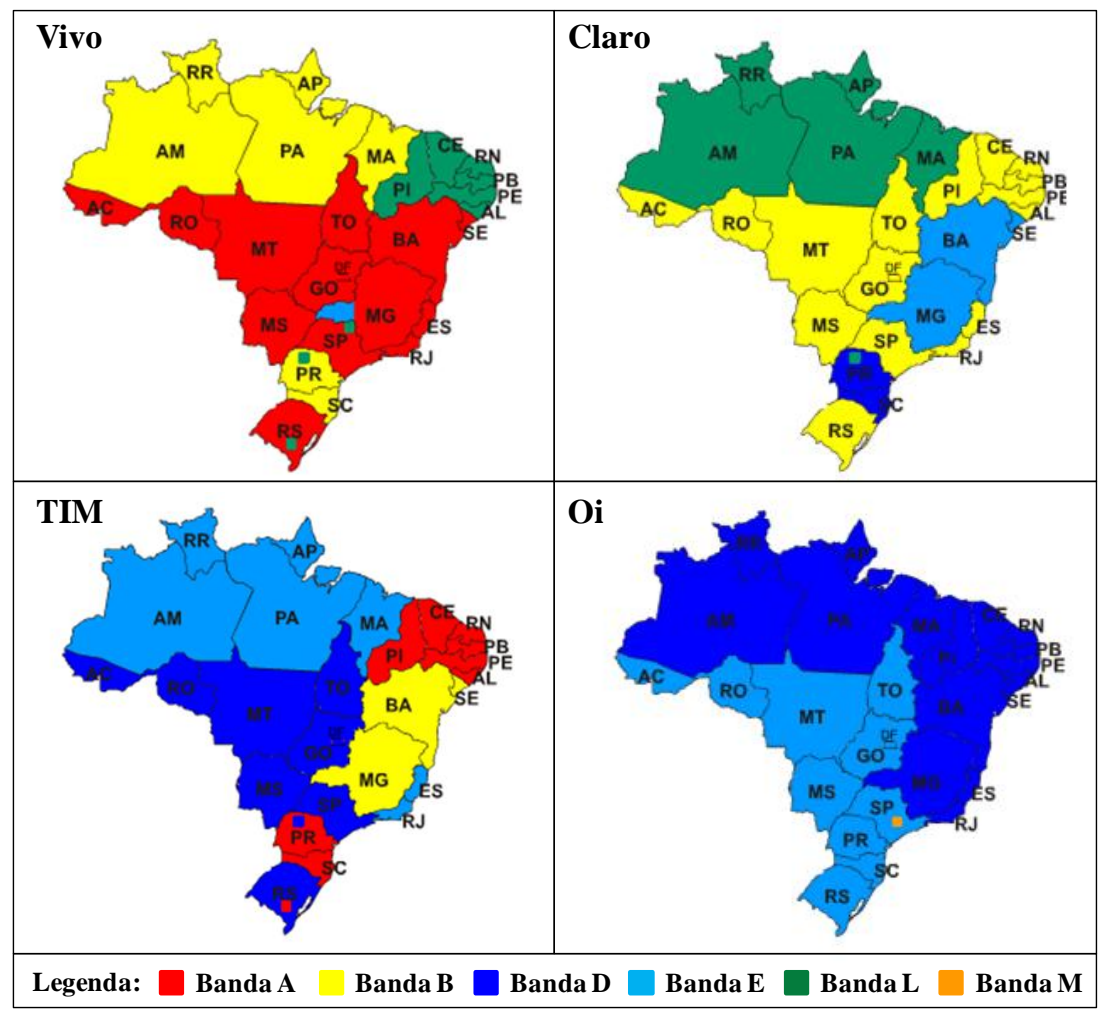

Ilustração 19 - Mapa de cobertura por banda de frequência

Fonte: Adaptado do site Teleco. Disponível em http://www.teleco.com.br/mapa.html Acessado em 10/08/2012. 


\subsubsection{Evolução do setor de telecomunicações brasileiro}

A expressividade do setor de telecomunicações na economia brasileira é notada pelo volume de investimentos e receitas nas diversas categorias da prestação do serviço. Segundo dados do SindiTelebrasil (Sindicato Nacional das Empresas de Telefonia e Serviço Móvel Celular e Pessoal), desde o período das privatizações até jun/2012 foram investidos no setor de telecomunicações cerca de 267 bilhões de reais, incluindo outorgas de 35,6 bilhões de reais; tem-se uma média de cerca de 18,3 bilhões de reais investidos anualmente. A receita bruta obtida pelo setor em 2011 alcançou um total de 200,5 bilhões de reais, o que representou 5\% do PIB brasileiro, crescendo 10,3\% em relação ao ano de 2010. Desde o ano 2000 até jun/2012, o setor já arrecadou cerca de 452,6 bilhões de reais em tributos e fundos setoriais e gera empregos diretos para mais de 507 mil pessoas segundo dados de jun/2012.

O gráfico 02 apresenta a evolução do número de linhas e/ou assinantes nas 4 principais categorias de serviços de telecomunicações no Brasil, a partir do ano 2000, logo após o processo de privatizações no setor. Merece destaque a rápida evolução da telefonia celular, que entre 2002 e 2003 tornou-se o maior mercado do setor, suplantando a telefonia fixa. Também é importante destacar o ritmo mais estável de evolução da telefonia fixa e os crescimentos dos mercados de TV por assinatura e de banda larga, ainda que a taxas muito inferiores relativamente à taxa de crescimento da telefonia celular, que alcançou quase $1.000 \%$ se considerados os últimos 11 anos.

Gráfico 02 - Evolução dos acessos em telecomunicações, por categoria

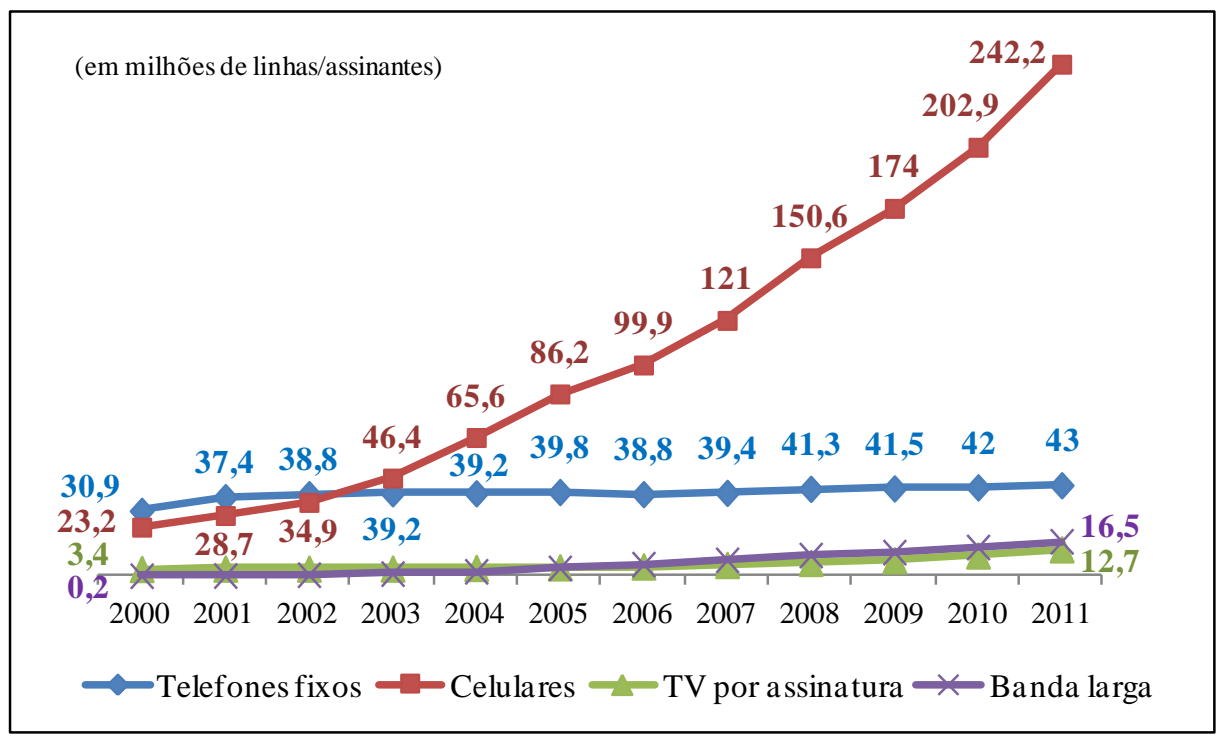

Fonte: Adaptado do site Teleco. Disponível em http://www.teleco.com.br/estatis.asp Acessado em 10/08/2012. 
Atualmente, o mercado de telefonia celular apresenta densidade acima de 100\%, alcançando em setembro/2012 a marca de 131,56\%, o que representa sua relevância no setor: é maior o número de linhas celulares em operação que o número de habitantes no Brasil. O gráfico 03 mostra a evolução histórica da densidade celular, com destaque para o período entre 2009 e 2010, quando o mercado superou a marca de $100 \%$.

\section{Gráfico 03 - Evolução da densidade da telefonia celular}

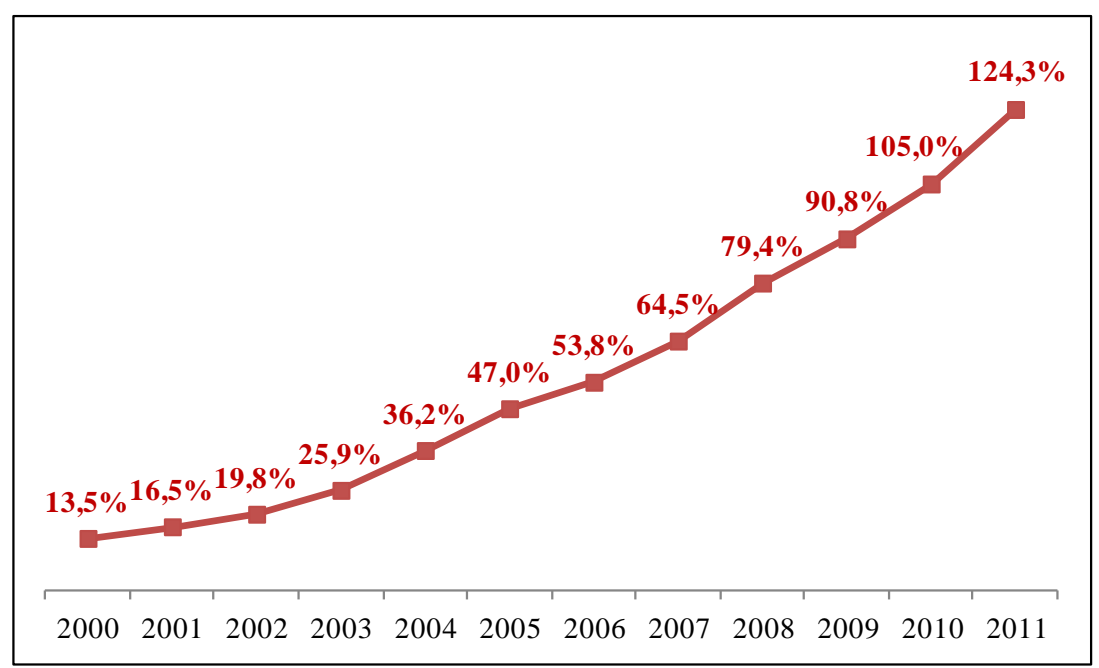

Fonte: Adaptado do site Teleco (número de linhas celulares / total da população brasileira).

Disponível em http://www.teleco.com.br/ncel.asp. Acessado em 10/08/2012.

O tamanho do mercado de celulares ao final de 2012 é de mais de 260 milhões celulares, dividido nas seguintes cotas de mercado entre as operadoras, com dados da Anatel, relativos a dezembro/2012: Vivo; 29,08\%; TIM, 26,88\%, Claro, 24,92\%; e Oi 18,81\%.

\section{Gráfico 04 - Divisão do mercado de telefonia celular, em dezembro/2012}

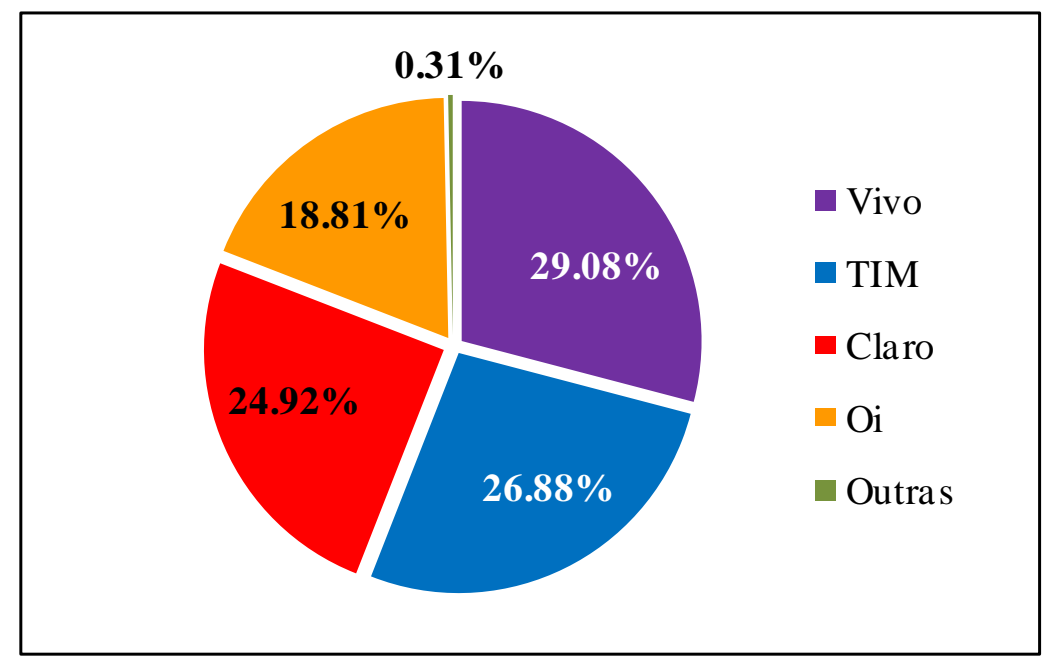

Fonte: Adaptado do site Teleco. Disponível em http://www.teleco.com.br/opcelular.asp Acessado em 05/03/2013. 
A evolução da participação de mercado das operadoras de telefonia celular é retratada no gráfico 05, com destaque para a forte liderança da empresa Vivo, em 2003, ano em que a marca foi lançada, com cerca de $50,2 \%$, o que se explica pelo fato de a operadora "herdar" o mercado das antigas operadoras estatais atuantes na banda A que formaram de imediato a sua base de clientes. A crescente competitividade do setor e a entrada das demais concorrentes em outras bandas de freqüência fizeram com que esta ampla vantagem da operadora Vivo se reduzisse até que o mercado entrou numa fase de equilíbrio em 2006. A partir desse ano, se observa maior estabilidade e certa manutenção das participações de mercado, cabendo destacar apenas a troca de posições entre as operadoras Claro e TIM: esta última perde a segunda colocação para Claro no ano de 2008 mas volta a recuperá-la no ano de 2011.

\section{Gráfico 05 - Evolução das participações de mercado das operadoras celulares}

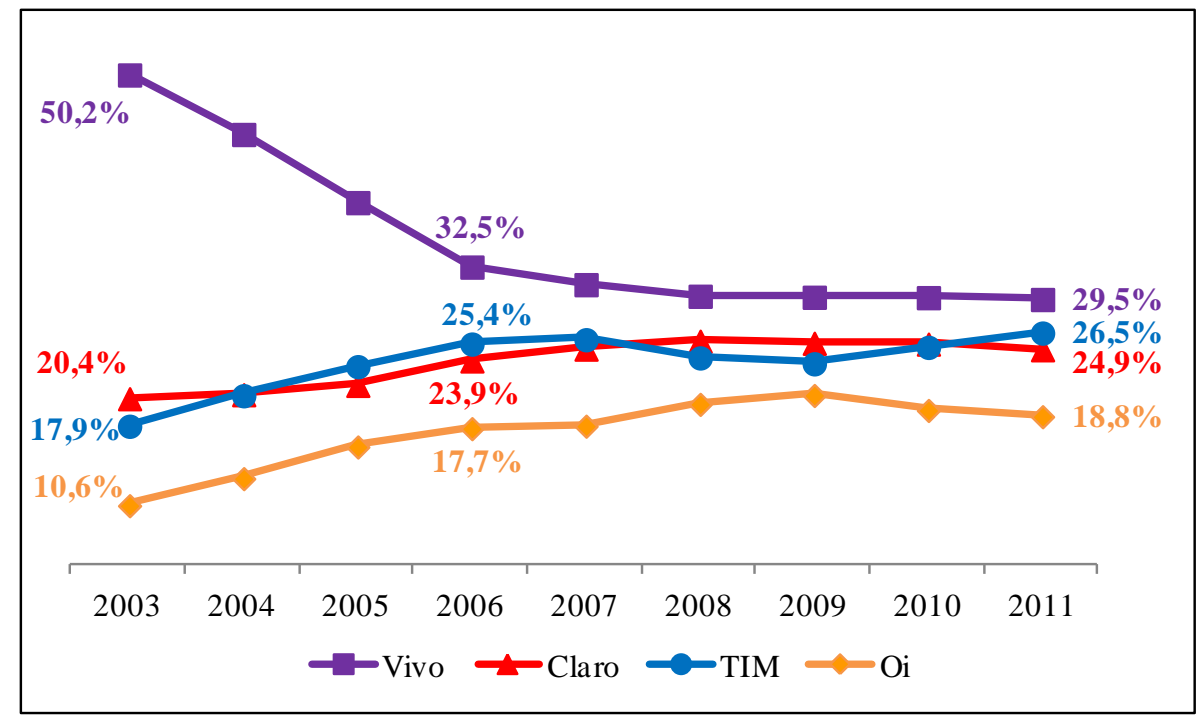

Fonte: Adaptado do site Teleco. Disponível em http://www.teleco.com.br/mshare.asp Acessado em 10/08/2012.

Especialmente no período pós-2006 vale analisar a evolução das participações de mercado das operadoras celulares nas duas principais formas de prestação do serviço: o pós-pago (modalidade de pagamento com conta, mais focada no mercado de alto valor) e pré-pago (modalidade de pagamento com cartão de recarga, mais focada no mercado de massa). Os gráficos a seguir indicam, no mercado de linhas pós-pagas, a liderança e o crescimento contínuo da operadora Vivo, enquanto a operadora TIM perde mercado e passa da segunda para a terceira posição. Já no mercado pré-pago a operadora Vivo mantém a liderança no período, porém com tendência de queda. A operadora TIM cresce em participação neste 
mercado no período, suplantando a segunda colocada, Claro, e aproxima-se de Vivo e da liderança.

Gráfico 06 - Evolução das participações de mercado das operadoras celulares nos segmentos pós e pré-pago.

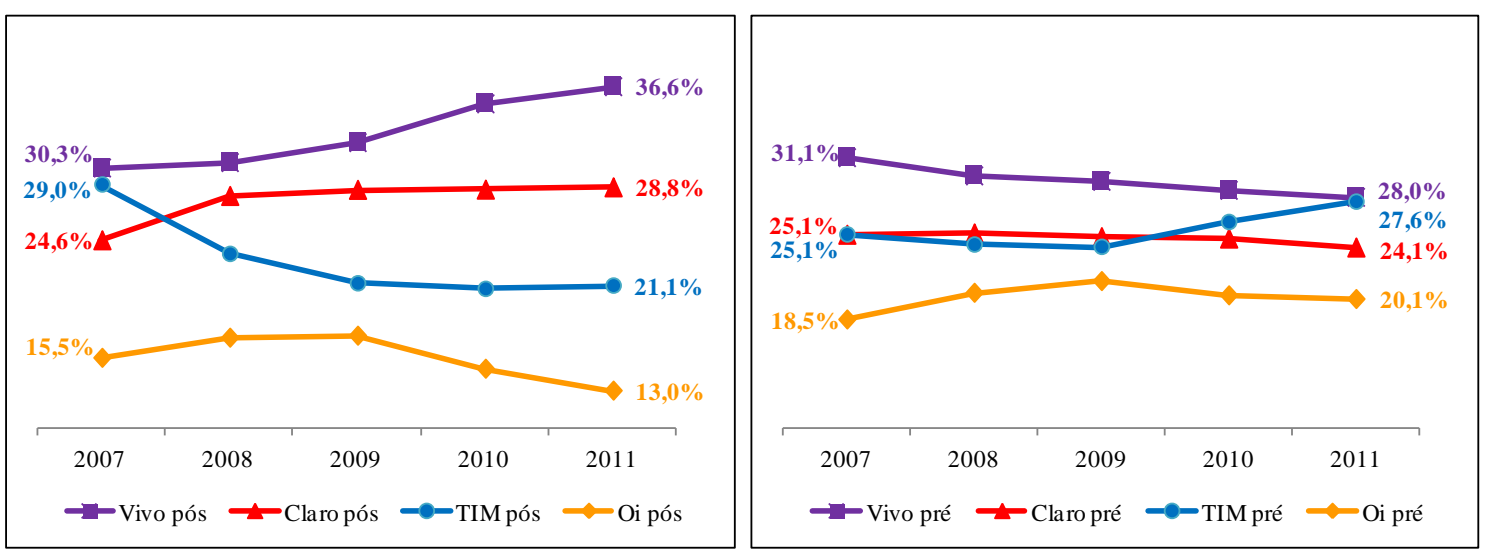

Fonte: Adaptado do site Teleco.

Disponível em http://www.teleco.com.br/mshare.asp. Acessado em 30/10/2012.

\subsubsection{Evolução dos acessos celulares por tecnologia no Brasil}

Segundo o site Teleco, em 1997, as operadoras celulares de SMC da Banda A foram separadas das operadoras de telefonia fixa e posteriormente privatizadas e houve a passagem da operadora do Rio de Janeiro - Telerj Celular - para a Banda A.

As licenças da Banda B foram licitadas e as operadoras entraram em operação na sua maior parte durante o ano de 1998. As operadoras da Banda B, com exceção da Global Telecom, na região 5 (Estados de PR/SC), implantaram sistemas digitais com tecnologia TDMA.

As operadoras da Banda A privatizadas migraram para CDMA nas regiões 1 e 2 (interior e capital do Estado de São Paulo, 3 (Estados de RJ e ES) e 9 (Estados de BA e SE) e para TDMA nas demais regiões. O terminais móveis utilizados passaram a ser duais, funcionando em AMPS/TDMA ou em AMPS/CDMA.

Por alguns anos a tecnologia TDMA instalada coexistiu com o processo de substituição pela tecnologia CDMA, nas operações que viriam a formar a empresa Vivo e pela tecnologia GSM nas operações que viriam a formar as empresas Claro, TIM e Oi. Mais a frente, de forma aparentemente inesperada, entre 2006 e 2007, a empresa Vivo substituiu toda a sua infraestrutura baseada em tecnologia CDMA pela tecnologia GSM. 
O gráfico 07 ilustra a evolução do número de linhas celulares em operação no Brasil nas diversas tecnologias apresentadas.

\section{Gráfico 07 - Evolução da base de clientes da telefonia celular vs. tecnologia de rede}

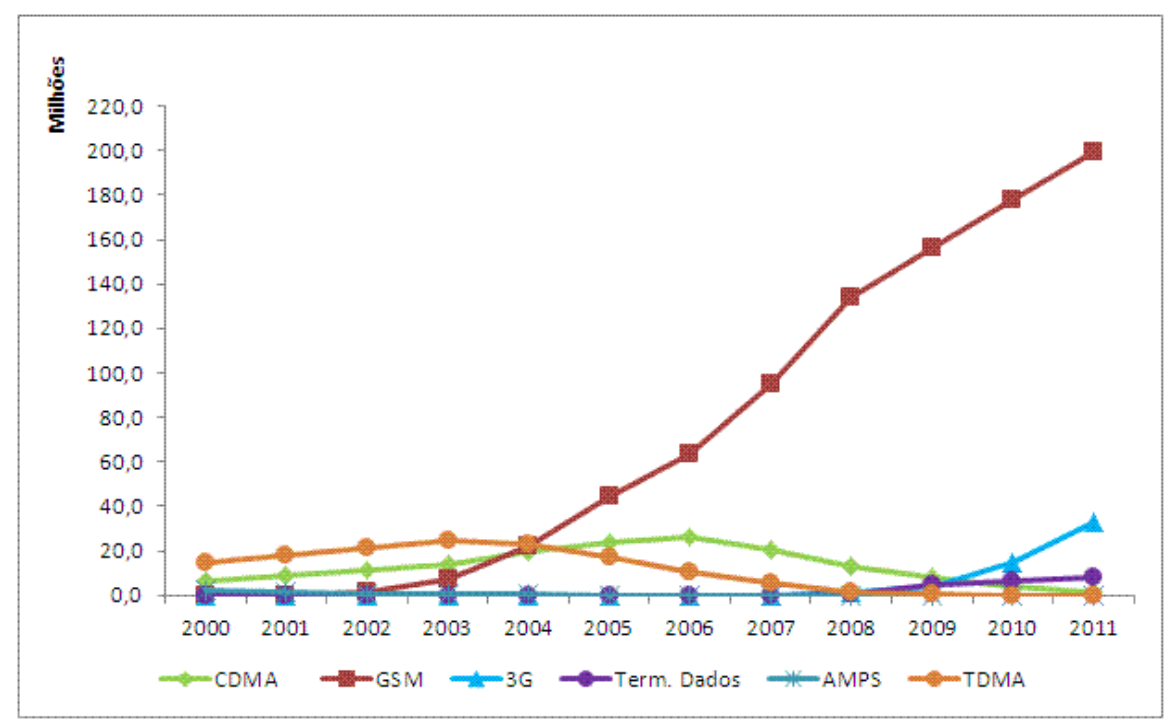

Fonte: Site Teleco. Disponível em http://www.teleco.com.br/tecnocel.asp. Acessado em 10/08/2012.

A análise do gráfico permite visualizar os movimentos de finalização de uso da tecnologia analógica de primeira geração (AMPS) a partir do ano 2001; de substituição da tecnologia TDMA por GSM e CDMA a partir de 2003; de substituição da tecnologia CDMA por GSM a partir de 2006; de crescimento contínuo da tecnologia GSM, com uso por todas as operadoras celulares brasileiras a partir de 2006; e por fim, crescimento das tecnologias de terceira geração a partir de 2009 (W-CDMA/HSPA/HSPA+).

\subsection{Modelo conceitual teórico}

Com o intuito de consolidar e relacionar literatura revisada ao longo do capítulo apresenta-se a seguir um modelo conceitual teórico, cuja estrutura também será contemplada ao longo da pesquisa empírica.

O modelo apresenta os temas e referencia, numa tabela junto à ilustração, os principais autores estudados em cada um deles, indicando a linha teórica considerada para a pesquisa. $\mathrm{O}$ modelo também evidencia os temas que são foco do estudo, graficamente identificados com linhas mais espessas, e situa o fenômeno investigado a partir da questão de pesquisa: introdução de inovação disruptiva e decisões de posicionamento. A relação entre os temas, que será aprofundado na pesquisa empírica, é destacada visualmente com as setas de cor azul. 
AMBIENTE:

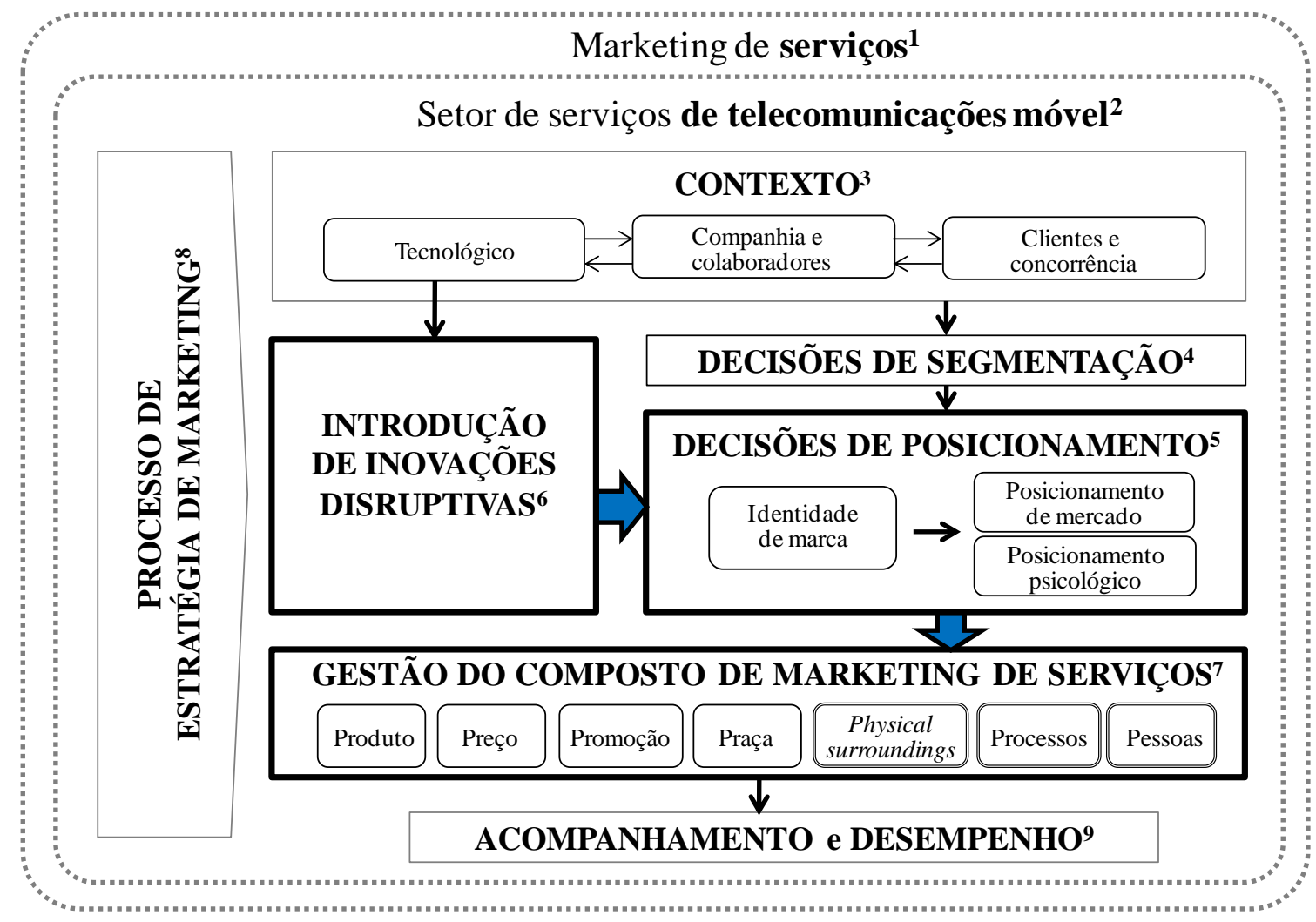

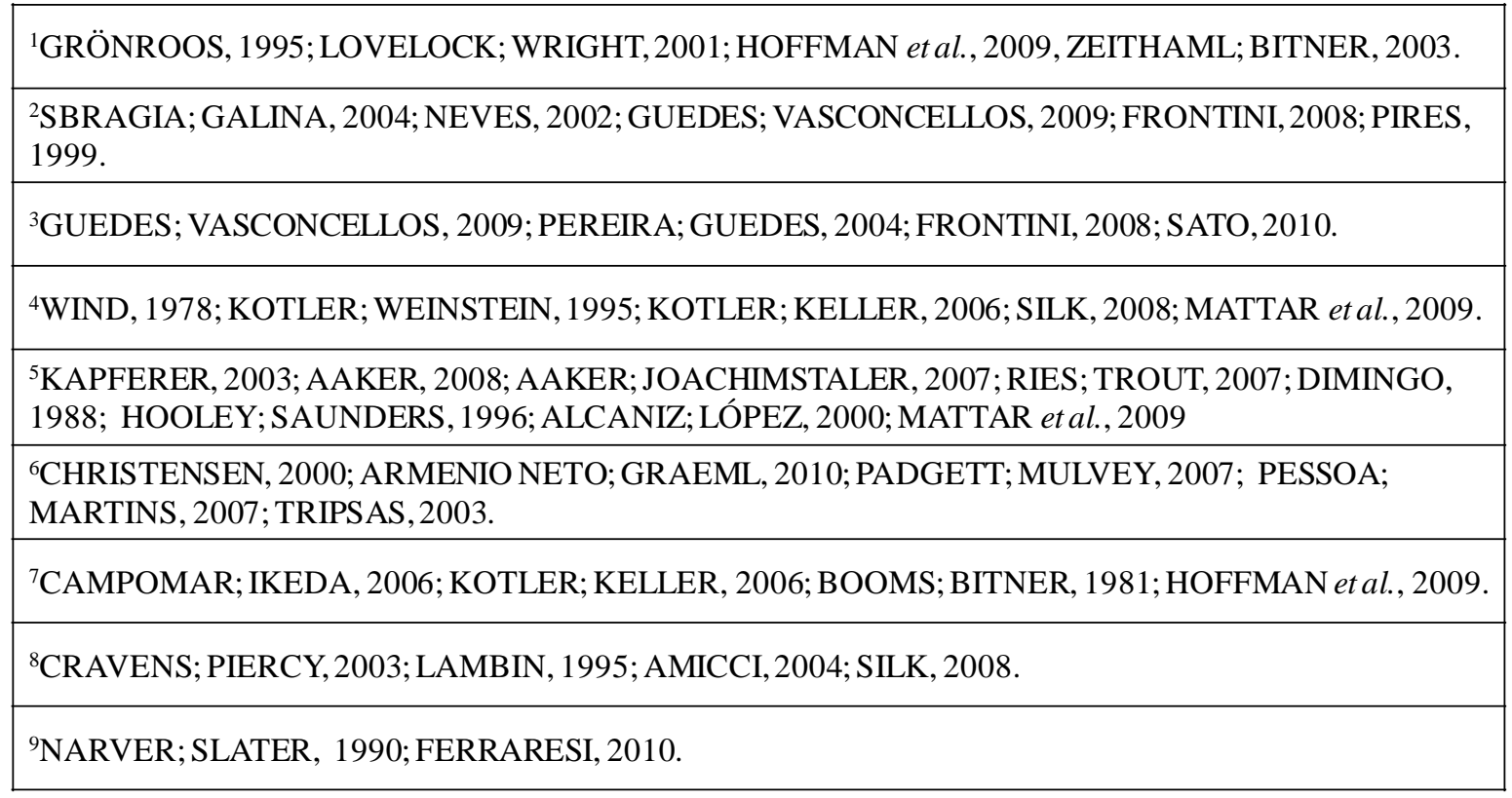

Ilustração 20 - Modelo conceitual teórico da pesquisa Fonte: Criado pelo autor 


\section{METODOLOGIA DE PESQUISA}

\subsection{Método e tipo de estudo}

Segundo Ander-Egg (1978), a ciência é um conjunto de conhecimentos racionais, certos ou prováveis, obtidos metodicamente sistematizados e verificáveis, que fazem referência a objetos de uma mesma natureza.

De acordo com Kuhn (1962, apud COLLIS; HUSSEY, 2005) paradigmas são realizações científicas universalmente reconhecidas que, por certo tempo, fornecem problemas e soluções-modelo para um comunidade de profissionais. Segundo Collis e Hussey (2005), há dois paradigmas de pesquisa, o positivista, que procura os fatos ou as causas de fenômenos sociais e o fenomenológico, que enfatiza os aspectos subjetivos da atividade humana focando o significado, e não a mensuração de fenômenos sociais. "Um fenômeno é um fato ou uma ocorrência que aparece ou é percebido, especialmente um cuja causa está em questão" (ALLEN, 1990, p.893 apud COLLIS; HUSSEY, 2005).

Como o paradigma adotado para uma pesquisa tem grande importância para a metodologia, cabe uma diferenciação mais precisa entre os paradigmas positivista e fenomenológico, conforme o quadro 11 distingue.

Quadro 11 - Características dos dois principais paradigmas

\begin{tabular}{ll}
\hline Paradigma positivista & Paradigma fenomenológico \\
\hline • Tende a produzir dados quantitativos & • Tende a produzir dados qualitativos \\
• Usa amostras grandes & • Usa amostras pequenas \\
• Interessa-se por testes de hipóteses & • Interessa-se pela geração de teorias \\
• Os dados são altamente específicos e & • Os dados são plenos de significados e \\
precisos & subjetivos \\
- A localização é artificial & • A localização é natural \\
- A confiabilidade é alta & • A confiabilidade é baixa \\
- A validade é baixa & • A validade é alta \\
- Generaliza de amostra para população & • Generaliza de um cenário para outro \\
\hline
\end{tabular}

Fonte: COLLIS; HUSSEY; 2005, p. 61.

Roesch (1999) defende que na visão fenomenológica a perspectiva de mundo e a realidade são socialmente construídas e recebem um significado a partir do homem. E nessa perspectiva, deve-se tentar explicar e entender por que as pessoas têm experiências diferentes, em vez de procurar causas externas e leis fundamentais para explicar seu comportamento. 
No que tange à diferença conceitual entre metodologia e método, Collis e Hussey (2005), definem metodologia como a maneira global de tratar o processo de pesquisa, da base teórica até a coleta e análise de dados. Já os métodos referem-se apenas às várias maneiras de coletar e/ou analisar dados.

Lakatos e Marconi (2010) complementam essa visão com a afirmação de que o método é o conjunto das atividades sistemáticas e racionais que, com maior segurança e economia, permite alcançar o objetivo - conhecimentos válidos e verdadeiros - traçando o caminho a ser seguido, detectando erros e auxiliando as decisões do cientista.

Em especial, os métodos de pesquisa usados na proposta fenomenologista são, segundo Van Maanen (1983, apud COLLIS; HUSSEY, 2005), uma série de técnicas interpretativas que procuram descrever, traduzir e, de outro modo, entender o significado e não a freqüência de determinados fenômenos que acontecem com mais ou menos naturalidade no mundo social.

Quanto à forma de se conhecer o fenômeno social em estudo, pode-se falar em dois enfoques de pesquisa: o quantitativo e o qualitativo. Sampieri et al. (2006) afirmam que o conhecimento do fenômeno social é a meta das ciências sociais em geral, mas no particular interessam as divergências. As diferenças entre os dois possíveis enfoques são colocadas por estes autores conforme síntese do quadro 12.

Quadro 12 - Diferenças entre os enfoques quantitativo e qualitativo META DAS CIÊNCIAS SOCIAIS $\longrightarrow$ CONHECER O FENÔMENO SOCIAL

\begin{tabular}{|c|c|c|}
\hline & Enfoque quantitativo & Enfoque qualitativo \\
\hline Ponto de partida & • Há uma realidade a conhecer & • Há uma realidade a descobrir \\
\hline Premissa & $\begin{array}{l}\text { - A realidade do fenômeno social } \\
\text { pode ser conhecida com a mente }\end{array}$ & $\begin{array}{l}\text { - A realidade do fenômeno social é } \\
\text { a mente. A realidade é construída } \\
\text { pelo(s) indivíduo(s) que dá (dão) } \\
\text { significados ao fenômeno social }\end{array}$ \\
\hline Dados & - Uso de medição e quantificação & - Uso da linguagem natural \\
\hline Finalidade & $\begin{array}{l}\text { - Busca relatar o que acontece. } \\
\text { Fatos que dêem informação } \\
\text { específica da realidade que } \\
\text { podemos explicar e prever }\end{array}$ & $\begin{array}{l}\text { - Busca entender o contexto e/ou o } \\
\text { ponto de vista do ator social }\end{array}$ \\
\hline
\end{tabular}

Fonte: SAMPIERI et al.; 2006, p. 9. 
Segundo Sampieri et al. (2006), o enfoque quantitativo usa coleta de dados para testar hipóteses com base na medição numérica e na análise estatística para estabelecer padrões de comportamento ao passo que o enfoque qualitativo utiliza coleta de dados sem medição numérica para descobrir ou aperfeiçoar questões de pesquisa e pode ou não provar hipóteses em seu processo de interpretação.

Campomar (1991) acrescenta que nos métodos qualitativos não há medidas e as possíveis inferências não são estatísticas e procura-se fazer análises em profundidade, obtendo-se até as percepções dos elementos pesquisados sobre os eventos de interesse. Lakatos e Marconi (2010) defendem ainda que a metodologia qualitativa preocupa-se em analisar e interpretar aspectos mais profundos, descrevendo a complexidade do comportamento humano e fornecendo análise mais detalhada sobre as investigações, hábitos, atitudes, tendências de comportamento.

Por fim, ao se considerar a concepção da pesquisa ainda se pode classificá-la, segundo Malhotra (2001), de forma ampla, como exploratória ou conclusiva. O principal objetivo da pesquisa exploratória é prover a compreensão do problema enfrentado pelo pesquisador enquanto a pesquisa conclusiva é geralmente mais formal e estruturada e é concebida para auxiliar o responsável pelas decisões a determinar, avaliar e selecionar o melhor curso de ação a ser tomado em determinada situação. A pesquisa conclusiva pode ainda ser categorizada como descritiva ou causal. O quadro 13 estabelece uma comparação entre estas diferentes concepções de pesquisa.

Quadro 13 - Comparação entre concepções básicas de pesquisa

\begin{tabular}{|c|c|c|c|}
\hline & Exploratória & Descritiva & Causal \\
\hline Objetivo & $\begin{array}{l}\text { - Descoberta de ideias } \\
\text { e dados }\end{array}$ & $\begin{array}{l}\text { - Descreve } \\
\text { características ou } \\
\text { funções do mercado }\end{array}$ & $\begin{array}{l}\text { - Determina relações } \\
\text { de causa e efeito }\end{array}$ \\
\hline Características & $\begin{array}{l}\text { - Flexível, versátil } \\
\text { - Com frequência, o } \\
\text { início da pesquisa }\end{array}$ & $\begin{array}{l}\text { - Marcada pela } \\
\text { formulação prévia de } \\
\text { hipóteses específicas } \\
\text { - Estudo pré-planejado } \\
\text { e estruturada }\end{array}$ & $\begin{array}{l}\text { - Manipulação de uma } \\
\text { ou mais variáveis } \\
\text { independentes } \\
\text { - Controle de outras } \\
\text { variáveis indiretas }\end{array}$ \\
\hline Métodos & $\begin{array}{l}\text { - Surveys com } \\
\text { especialistas } \\
\text { - Surveys piloto } \\
\text { - Dados secundários } \\
\text { - Pesquisa qualitativa }\end{array}$ & $\begin{array}{l}\text { - Dados secundários } \\
\text { - Surveys } \\
\text { - Paineis } \\
\text { - Dados de } \\
\text { observações outros } \\
\text { dados }\end{array}$ & - Experimentos \\
\hline
\end{tabular}


Yin (2010) acrescenta ainda que o método a utilizar na pesquisa depende de três condições, que consistem no tipo de questão proposto, na extensão do controle que o investigador tem sobre os eventos comportamentais reais e no grau de enfoque sobre eventos contemporâneos em oposição aos eventos históricos.

Quadro 14 - Situações relevantes para diferentes métodos de pesquisa

\begin{tabular}{|l|l|l|l|}
\hline Método & $\begin{array}{l}\text { Forma de questão } \\
\text { de pesquisa }\end{array}$ & $\begin{array}{l}\text { Exige controle } \\
\text { sobre eventos } \\
\text { comportamentais }\end{array}$ & $\begin{array}{l}\text { Enfoca } \\
\text { acontecimentos } \\
\text { contemporâneos }\end{array}$ \\
\hline Experimento & Como, por quê & Sim & Sim \\
\hline Levantamento & $\begin{array}{l}\text { Quem, o quê, onde, } \\
\text { quantos, quanto }\end{array}$ & Não & Sim \\
\hline Análise de arquivos & $\begin{array}{l}\text { Quem, o quê, onde, } \\
\text { quantos, quanto }\end{array}$ & Não & Sim/não \\
\hline Pesquisa histórica & Como, por quê & Não & Não \\
\hline Estudo de caso & Como, por quê & Não & Sim \\
\hline
\end{tabular}

Fonte: YIN; 2010, p. 29.

Frente à questão de pesquisa proposta para este estudo, para se buscar compreender de que forma o posicionamento de marca de serviço no setor de telecomunicações é afetado pela introdução de inovação disruptiva, optou-se pela condução de uma pesquisa empírica de enfoque qualitativo e de caráter exploratório de forma a complementar a pesquisa bibliográfica realizada.

A estratégia de pesquisa adotada é o estudo de caso, que será detalhada no tópico seguinte. Optou-se por um estudo de caso único, em que o universo de pesquisa, ou unidade de pesquisa, é o caso selecionado para o estudo, a empresa de telecomunicações brasileira Vivo.

A seleção da empresa Vivo para o estudo de caso se relaciona diretamente às características peculiares de sua atuação, que permitem situá-la no escopo de investigação para compreensão do fenômeno de interesse enunciado pela questão de pesquisa. $\mathrm{O}$ fato de a empresa ter realizado mudanças de tecnologia - com a introdução de uma inovação disruptiva (da tecnologia CDMA para a tecnologia GSM) - de forma concomitante à mudança de posicionamento de marca, trazem um contexto relevante de análise aprofundada para o estudo em questão. Cabe destacar que a Vivo foi a única empresa deste mercado a registrar este tipo de movimento tecnológico, o que evidencia o caráter peculiar do caso. 


\subsection{Estratégia de pesquisa}

Segundo Yin (2010), o estudo de casos é uma investigação empírica que investiga um fenômeno contemporâneo em profundidade e em seu contexto de vida real, especialmente quando os limites entre o fenômeno e o contexto não são claramente evidentes. Para Lakatos e Marconi (2010), a investigação procura entender o significado do sistema próprio dos entrevistados. Não se podem antecipar os aspectos do sistema significativo, nem o contexto do funcionamento na totalidade que só é possível conhecer posteriormente.

Estudos de caso podem ser utilizados para cumprir diversos objetivos: fornecer uma descrição, testar uma teoria ou gerar uma teoria. Segundo Martins (2008) por meio do estudo de caso, busca-se, criativamente identificar e analisar a multiplicidade de dimensões que envolvem o caso - e, de maneira engenhosa, descrever, discutir e analisar a complexidade de um caso concreto, construindo uma teoria que possa explicá-lo e prevê-lo.

Yin (2010) defende ainda que a investigação do estudo de caso enfrenta a situação tecnicamente diferenciada em que existirão muito mais variáveis de interesse do que pontos de dados, e, como resultado conta com múltiplas fontes de evidência, com os dados precisando convergir de maneira triangular. De acordo com Martins (2008), o estudo de caso possibilita a penetração em uma realidade social, não conseguida plenamente por um levantamento amostral e avaliação exclusivamente quantitativa.

Para Lakatos e Marconi (2010), no estudo de caso qualitativo não há um esquema estrutural aprioristicamente; assim, não se organiza um esquema de problemas, hipóteses e variáveis com antecipação. Martins (2008) complementa que é preciso determinar o âmbito da pesquisa e estabelecer os contornos do estudo, caracterizando precisamente seu foco e seus limites periféricos. Tal procedimento se faz necessário, pois nunca será possível explorar todos os ângulos do fenômeno.

Segundo Sampieri et al. (2006), o caso deve ser tratado com profundidade, buscando o completo entendimento de sua natureza, suas circunstâncias, seu contexto e suas características. Os autores resumem os principais passos nesse tipo de pesquisa como exposto no diagrama da ilustração 21. 


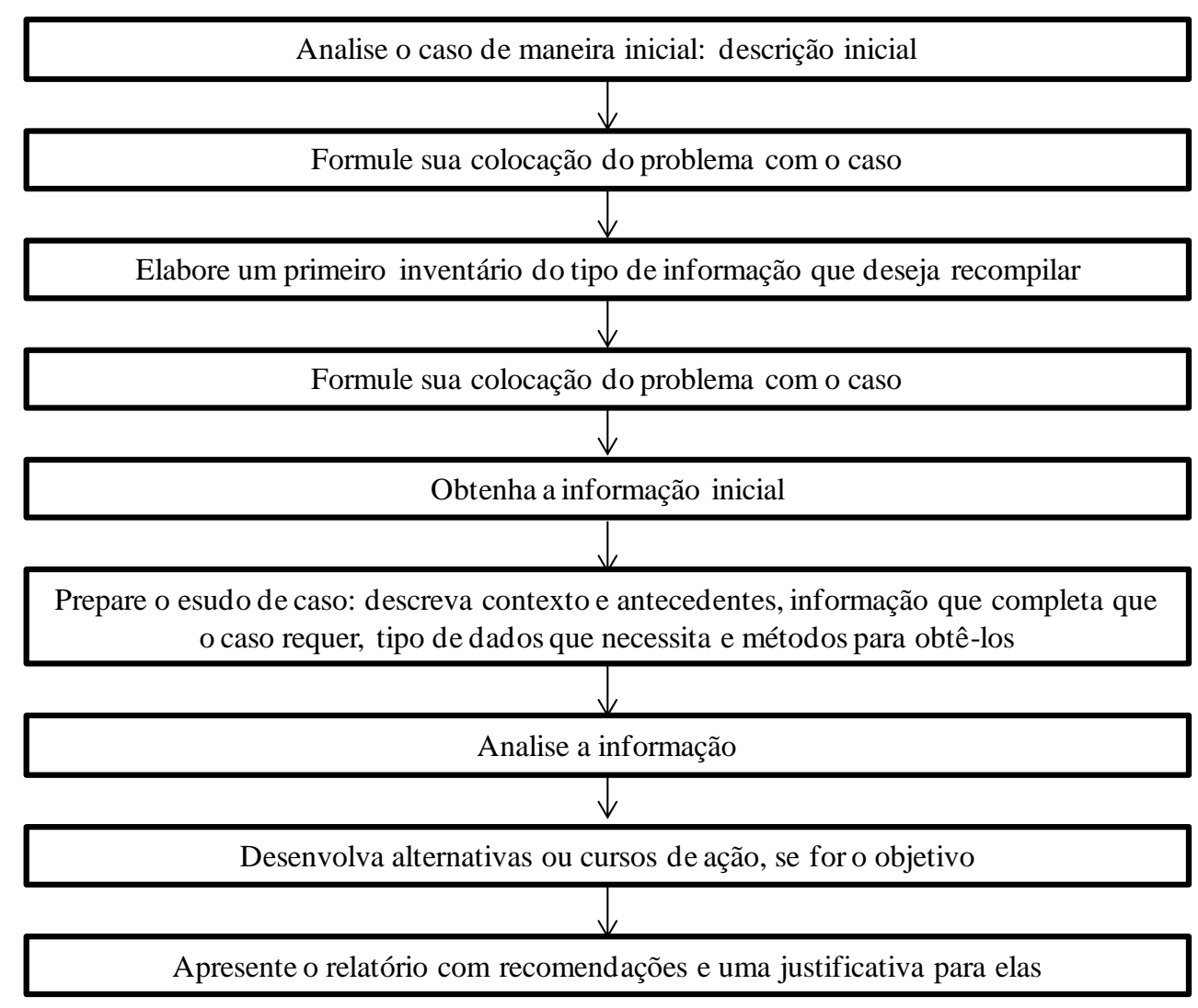

\section{Ilustração 21 - Etapas do estudo de caso} Fonte: SAMPIERI et al.; 2006, p. 276.

Segundo Stake (2000, apud SAMPIERI et al., 2006), três diferentes tipos de estudos de caso podem ser identificados: os intrínsecos, os instrumentais e os coletivos.

O objetivo dos primeiros não é elaborar uma teoria, mas sim que o próprio caso seja interessante. Os estudos de caso instrumentais são examinados para fornecer material de conhecimento para algum tema ou problema de pesquisa, refinar uma teoria ou aprender a trabalhar com outros casos similares. Por sua vez, os coletivos servem para construir um corpo teórico, somando descobertas, encontrando elementos comuns e diferenças, acumulando informação (SAMPIERI et al., 2006, p.276).

Já para Yin (2010) existem ao menos quatro aplicações diferentes para os estudos de caso.

O mais importante é explicar os presumidos vínculos causais nas intervenções da vida real que são demasiado complexos para as estratégias de levantamento ou experimentais. Uma segunda aplicação é descrever uma intervenção e o contexto da vida real no qual ela ocorreu. Em terceiro lugar, os estudos de caso podem ilustrar determinados tópicos em uma avaliação, novamente em um modo descritivo. Em quarto lugar, a estratégia de estudo de caso pode ser usada para explorar as situações em que a intervenção sendo avaliada não possui um único e claro conjunto de resultados (YIN, 2010, p.41).

O estudo de casos envolve a análise intensiva de um número relativamente pequeno de situações e, às vezes, o número de casos estudados reduz-se a um. É dada ênfase à completa descrição e ao entendimento do relacionamento dos fatores de cada situação, não importando 
os números envolvidos (BOYD; STASCH, 1985 apud CAMPOMAR, 1991). É o que também defende Triviños (1987, apud LAKATOS; MARCONI, 2010), ao afirmar que o estudo de caso é uma categoria de pesquisa cujo objeto é uma unidade que se analisa profundamente.

Para Eisenhardt (1989), o estudo de caso foca no entendimento da dinâmica presente dentro de um único ambiente. Collis e Hussey (2005) afirmam que uma unidade de análise é o tipo de caso ao qual as variáveis ou fenômenos sendo estudados e o problema de pesquisa se referem, e sobre o qual se coletam e analisam dados.

Yin (2010) apresenta quatro possíveis tipos de projetos de estudos de caso, que consideram o desejo de analisar as condições contextuais em relação ao caso, o número de casos analisados e as possibilidades de existência de unidades de análise unitárias ou múltiplas.

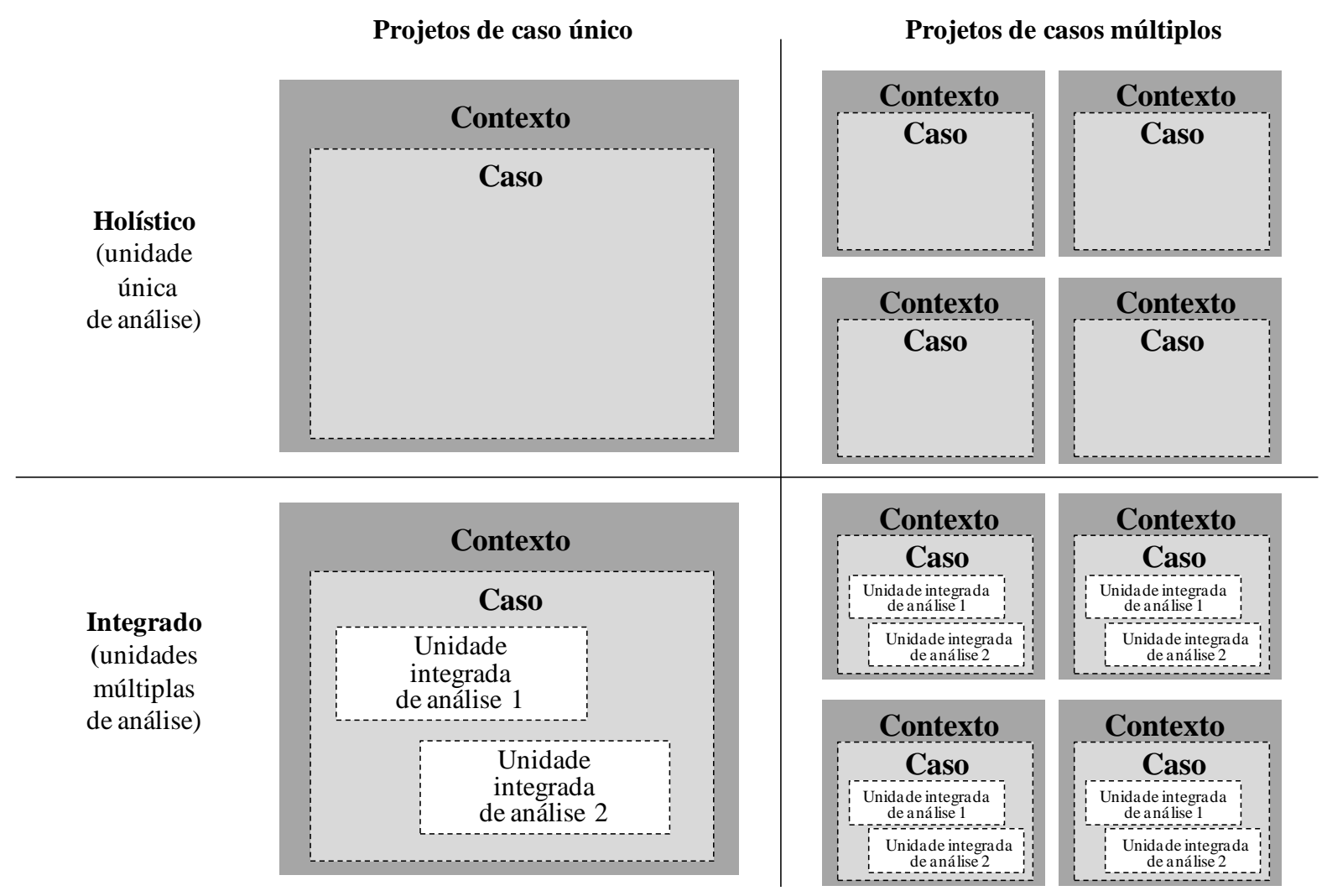

Ilustração 22 - Tipos básicos de projetos para estudos de casos

Fonte: YIN; 2010, p. 70.

Segundo Yin (2010), uma justificativa para o caso único é quando ele representa o caso crítico no teste de uma teoria bem formulada. Uma segunda justificativa é quando ele representa um caso extremo ou peculiar, em que algum fenômeno raro chega a ser único e merece ser documentado e analisado. Outras justificativas são o caso revelador, quando se 
tem a oportunidade de observar e analisar um evento previamente inacessível à investigação da ciência, e o caso longitudinal, em que se realiza o estudo de um mesmo caso único em dois ou mais pontos diferentes do tempo.

Para este estudo, dado o caráter peculiar do fenômeno enfocado, optou-se pela realização de um estudo de caso único, com múltiplas unidades de análise. A construção do referencial teórico serviu de base não apenas para a construção da questão de pesquisa, mas também para mapear as unidades de análise relevantes para investigação do fenômeno destacado. No caso, as unidades de análise são os profissionais que representam as principais áreas da empresa envolvidas no fenômeno estudado e estão diretamente relacionados aos fatores do composto de marketing de serviços, devidamente identificados no referencial teórico.

\subsubsection{Protocolo de pesquisa}

De acordo com Martins (2008), o trabalho de campo deverá ser precedido por um detalhado planejamento, a partir de ensinamentos advindos do referencial teórico e das características próprias do caso.

Um protocolo de pesquisa contém os procedimentos, os instrumentos e as regras gerais que devem ser seguidas e se constitui numa tática para aumentar a fidedignidade da pesquisa. Segundo Yin (1989, apud BRESSAN, 2000), este protocolo ou manual deve conter: (1) uma visão geral do projeto do estudo de caso - objetivos, ajudas, as questões do estudo de caso e as leituras relevantes sobre os tópicos a serem investigados; (2) os procedimentos de campo; (3) as questões do estudo de caso que o investigador deve ter em mente, os locais, as fontes de informação, os formulários para o registro dos dados e as potenciais fontes de informação para cada questão; e (4) um guia para o relatório do estudo de caso.

Em suma, para Martins (2008), o protocolo se constitui em um conjunto de códigos, menções e procedimentos suficientes para replicar o estudo, ou aplicá-lo em outro caso que mantém características semelhantes ao estudo de caso original. Além disso, o protocolo oferece condição prática para se testar a confiabilidade do estudo, isto é, obterem-se resultados assemelhados em aplicações sucessivas a um mesmo caso.

Segundo Alreck e Settle (1995), confiabilidade significa ausência de erro aleatório. Em outras palavras, para se ter confiabilidade é necessário haver uma regularidade no procedimento de execução de um estudo (se chegar a dados de mesmo valor através de várias medições realizadas de modo idêntico). Martins (2006) acrescenta que a confiabilidade de um 
instrumento para coleta de dados ou teste é sua coerência, determinada através da constância dos resultados. Em outras palavras, a confiabilidade de uma medida é a confiança que a mesma inspira.

Para Yin (2010), quatro tipos de testes podem ser utilizados para estabelecer a qualidade de qualquer pesquisa social empírica, incluindo o estudo de casos. Para cada um deles, são identificadas táticas a considerar nas diversas fases de condução do estudo. O quadro 15 apresenta cada um dos testes e sumariza estas possibilidades.

\section{Quadro 15 - Táticas de estudo de caso para quatro testes de projeto}

\begin{tabular}{|c|c|c|c|}
\hline $\begin{array}{l}\text { Testes } \\
\text { de caso }\end{array}$ & Finalidade & $\begin{array}{l}\text { Tática } \\
\text { do estudo }\end{array}$ & $\begin{array}{l}\text { Fase da pesquisa } \\
\text { em que ocorre }\end{array}$ \\
\hline $\begin{array}{l}\text { Validade do } \\
\text { constructo }\end{array}$ & $\begin{array}{l}\text { - Identificação das medidas } \\
\text { operacionais corretas para os } \\
\text { conceitos sendo estudados }\end{array}$ & $\begin{array}{l}\text { - Usa múltiplas fontes de evidência } \\
\text { - Estabelece encadeamento de } \\
\text { evidências } \\
\text { - Tem informantes-chave para a } \\
\text { revisão do rascunho do relatório }\end{array}$ & $\begin{array}{l}\text { - Coleta de dados } \\
\text { - Coleta de dados } \\
\text { - Composição }\end{array}$ \\
\hline $\begin{array}{l}\text { Validade } \\
\text { interna }\end{array}$ & $\begin{array}{l}\text { - Apenas para estudos } \\
\text { explanatórios ou causais } \\
\text { - Busca do estabelecimento da } \\
\text { relação causal pela qual se } \\
\text { acredita que determinadas } \\
\text { condições levam a outras } \\
\text { condições, diferenciadas das } \\
\text { relações espúrias }\end{array}$ & $\begin{array}{l}\text { - Realiza a combinação de padrão } \\
\text { - Realiza a construção da } \\
\text { explanaçãa } \\
\text { - Aborda as explanações rivais } \\
\text { - Usa modelos lógicos }\end{array}$ & $\begin{array}{l}\text { - Análise de dados } \\
\text { - Análise de dados } \\
\text { - Análise de dados } \\
\text { - Análise de dados }\end{array}$ \\
\hline $\begin{array}{l}\text { Validade } \\
\text { externa }\end{array}$ & $\begin{array}{l}\text { - Definir o domínio para o qual } \\
\text { as descobertas do estudo podem } \\
\text { ser generalizados }\end{array}$ & $\begin{array}{l}\text { - Usa a teoria nos estudos de caso } \\
\text { únicos } \\
\text { - Usa a lógica da replicação nos } \\
\text { estudos de caso múltiplos }\end{array}$ & $\begin{array}{l}\text { - Projeto de pesquisa } \\
\text { - Projeto de pesquisa }\end{array}$ \\
\hline Confiabilidade & $\begin{array}{l}\text { - Demonstração de que as } \\
\text { operações de um estudo - como } \\
\text { os procedimentos para a coleta } \\
\text { de dados - podem ser repetidas, } \\
\text { com os mesmos resultados }\end{array}$ & $\begin{array}{l}\text { - Usa o protocolo do estudo de caso } \\
\text { - Desenvolve uma base de dados de } \\
\text { estudo de caso }\end{array}$ & $\begin{array}{l}\text { - Coleta de dados } \\
\text { - Coleta de dados }\end{array}$ \\
\hline
\end{tabular}

Fonte: Adaptado de YIN; 2010, p. 63-64.

O protocolo de pesquisa desenvolvido para este estudo encontra-se detalhado ao final (APÊNDICE 1), com especial atenção aos critérios para garantia da confiabilidade e da validade do constructo. $\mathrm{O}$ projeto de pesquisa também se preocupou com a definição de um modelo conceitual para a pesquisa teórica de forma a garantir a validade externa do estudo. 


\subsubsection{Coleta de dados}

Segundo Roesch (1999), entrevistas, observação e uso de diários são as técnicas mais utilizadas na pesquisa de caráter qualitativo, sendo a entrevista em profundidade considerada a técnica fundamental e o método básico das Ciências Sociais.

Para Eisenhardt (1989), estudos de caso tipicamente combinam métodos de coleta de dados tais como arquivos, entrevistas, questionários e observações. A evidência pode ser qualitativa, quantitativa, ou ambas.

De acordo com Yin (2010) as fontes de evidência mais comumente usadas na realização do estudo de caso são: documentação, registros em arquivos, entrevistas, observações diretas, observação participante e artefatos físicos. Destacam-se no quadro 16 os pontos fortes e fracos das três principais fontes utilizadas neste estudo.

Quadro 16 - Pontos fortes e fracos das fontes de evidência

\begin{tabular}{|c|c|c|}
\hline $\begin{array}{l}\text { Fonte de } \\
\text { evidência }\end{array}$ & Pontos fortes & Pontos fracos \\
\hline Documentação & $\begin{array}{l}\text { - Estável - pode ser revista } \\
\text { repetidamente } \\
\text { - Discreta - não foi criada em } \\
\text { conseqüência do estudo de caso } \\
\text { - Exata - contém nomes, referências e } \\
\text { detalhes exatos de um evento } \\
\text { - Ampla cobertura - longo período de } \\
\text { tempo, muitos eventos e muitos } \\
\text { ambientes }\end{array}$ & $\begin{array}{l}\text { - Recuperabilidade - pode ser difícil de } \\
\text { encontrar } \\
\text { - Seletividade parcial,se a coleção for } \\
\text { incompleta } \\
\text { - Parcialidade do relatório - reflete } \\
\text { parcialidade (desconhecida) do autor } \\
\text { - Acesso - pode ser negado } \\
\text { deliberadamente }\end{array}$ \\
\hline $\begin{array}{l}\text { Registros } \\
\text { em arquivo }\end{array}$ & $\begin{array}{l}\text { - [idem à documentação] } \\
\text { - Precisos e geralmente quantitativos }\end{array}$ & $\begin{array}{l}\text { - [idem à documentação] } \\
\text { - Acessibilidade devido a razões de } \\
\text { privacidade }\end{array}$ \\
\hline Entrevistas & $\begin{array}{l}\text { - Direcionadas - focam diretamente os } \\
\text { tópicos do estudo de caso } \\
\text { - Perceptíveis - fornecem inferências e } \\
\text { explanações causais percebidas }\end{array}$ & $\begin{array}{l}\text { - Parcialidade devido às questões mal } \\
\text { articuladas } \\
\text { - Parcialidade da resposta } \\
\text { - Incorreções devido à falta de memória } \\
\text { - Reflexividade - o entrevistado dá ao } \\
\text { entrevistador o que ele quer ouvir }\end{array}$ \\
\hline
\end{tabular}

Fonte: Adaptado de YIN; 2010, p. 129.

Segundo Martins (2008), a realização de pesquisa documental é necessária para o melhor entendimento do caso e também para corroborar evidências coletadas por outros instrumentos e outras fontes, possibilitando a confiabilidade de achados através de triangulações de dados e resultados. 
Malhotra (2001) defende que os dados secundários podem ser classificados em dados internos, gerados na organização em que está sendo realizada a pesquisa, e em dados externos, gerados por fontes externas à organização. $\mathrm{O}$ diagrama da ilustração 23 resume uma visão geral sobre as possíveis formas de dados secundários.

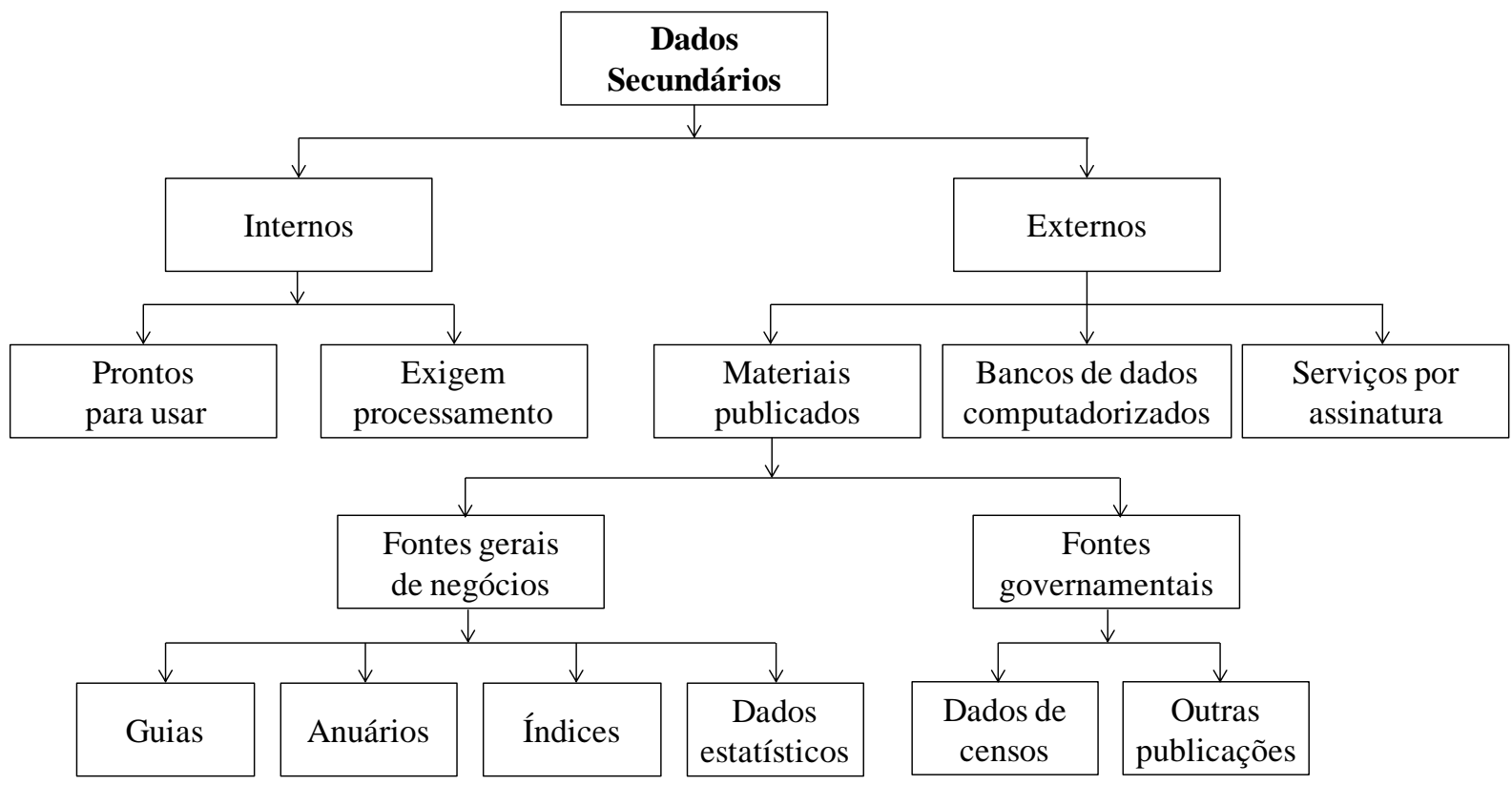

Ilustração 23 - Classificação de dados secundários

Fonte: Adaptado de MALHOTRA; 2001, p. 131 e 134.

Para o levantamento de dados secundários considerou-se a documentação indireta, como sugerem Marconi e Lakatos (2003), que se utiliza da pesquisa documental e pesquisa bibliográfica com intuito de recolher informações prévias sobre o campo de interesse. Foram utilizadas fontes escritas e não escritas, contemporâneas e retrospectivas, tanto de ordem pública como particular, além de fontes estatísticas e outras fontes como a imprensa escrita e meios audiovisuais.

Foster (1994, apud ROESCH, 1999) argumenta que documentos têm um valor em si mesmo representam sistemas e estruturas da organização. Sua análise permite o entendimento de situações e conceituar a organização com base numa visão de dentro. 
Entre os diversos documentos coletados na empresa Vivo, foram considerados:

- Relatórios anuais de administração;

- Apresentações de resultados aos acionistas e analistas de mercado;

- Relatórios de paineis e pesquisas de mercado e consumidor;

- Relatórios de dados de resultados financeiros e operacionais;

- Registros de discursos internos da alta administração;

- Materiais de comunicação interna (endomarketing) e externa (publicidade e propaganda nos diversos meios);

- Planos estratégicos e operacionais relativos ao momento do fenômeno que se estuda, na medida em que puderam ser compartilhados para o estudo.

A segunda e principal forma de coleta de dados são as entrevistas com os executivos da empresa, com grau relevante de envolvimento com o fenômeno peculiar estudado no caso. Foram entrevistados executivos atualmente atuantes na empresa e também executivos egressos.

As entrevistas seguiram o tipo de entrevista em profundidade não-estruturada, pois neste tipo de entrevista, como apontam Marconi e Lakatos (2003), o entrevistador tem liberdade para desenvolver cada situação em qualquer condição que considere adequada. É uma forma de poder explorar mais amplamente uma questão. Roesch (1999) defende ainda que a entrevista em profundidade tem como objetivo primário entender o significado que os entrevistados atribuem a questões e situações em contextos que não foram estruturados anteriormente a partir das suposições do pesquisador.

Martins (1998) acrescenta que na condução de uma entrevista não estruturada, ou uma entrevista semiestruturada, o entrevistador, por meio de uma conversação livre, busca obter informações sobre um tema específico, a fim de levantar motivações, crenças, percepções e atitudes em relação a certa situação e/ou objeto de investigação. Roesch (1999) acrescenta que o grau de estruturação de uma entrevista em uma pesquisa qualitativa depende do propósito do entrevistador. Em entrevistas semiestruturadas utilizam-se questões abertas, que permitem ao entrevistador entender e captar a perspectiva dos participantes da pesquisa.

Neste estudo as perguntas são em sua maioria abertas, com a possibilidade de serem respondidas dentro de uma conversação informal. Para estabelecer uma visão ampla do evento 
peculiar estudado, buscou-se entrevistar executivos selecionados segundo suas áreas de atuação e proximidade e envolvimento com o fenômeno.

As entrevistas semiestruturadas foram conduzidas pessoalmente pelo autor deste estudo, durante os meses de abril e maio de 2013, de forma individual, segundo o critério não disfarçado, com o apoio de um roteiro de pesquisa composto por 6 questões fechadas que descrevem o perfil do entrevistado, 9 questões abertas comuns a todos os entrevistados e um bloco final com 3 a 5 questões abertas que variam conforme a área de atuação do entrevistado. Este instrumento de pesquisa está detalhado ao final do trabalho (APÊNDICE 3).

O roteiro de entrevista foi pré-testado com a colaboração de outros dois profissionais da empresa que não foram selecionados como unidade de análise do estudo. Segundo Gil (2006), o pré-teste deve assegurar que o questionário esteja bem elaborado, sobretudo no referente a (1) clareza e precisão dos termos; (2) forma das questões; (3) desmembramento das questões. (4) ordem das questões; e (5) introdução do questionário.

\subsubsection{Análise de dados}

Para Collis e Hussey (2005), alguns métodos de coleta de dados qualitativos estão tão próximos da análise dos dados que é impossível separar os dois processos. Segundo Roesch (1999), na pesquisa de caráter qualitativo, o pesquisador, ao encerrar sua coleta de dados, se depara com uma quantidade imensa de notas de pesquisa ou de depoimentos, que se materializam na forma de textos, os quais terá de organizar para depois interpretar.

Segundo Yin (2010), a análise dos dados consiste no exame, na categorização, na tabulação, no teste ou nas evidências recombinadas de outra forma, para tirar conclusões baseadas empiricamente. Para Dey (1993, apud SAMPIERI et al., 2006), nos estudos qualitativos a análise dos dados não está completamente determinada, mas sim é prefigurada, coreografada, ou esboçada, ou seja, começa-se a efetuar sob um plano geral, entretanto seu desenvolvimento vai sofrendo modificações de acordo com os resultados.

Collis e Hussey (2005) defendem a possibilidade de realização da análise de dados seguindo métodos quantitativos, em que formal ou informalmente se transformam os dados qualitativos em dados numéricos, ou seguindo métodos não-quantitativos, em que os dados não são quantificados, mas precisam ser reduzidos, estruturados e apresentados graficamente. O quadro 17 resume os métodos possíveis, segundo estes autores. 
Quadro 17 - Principais métodos de análise de dados qualitativos

\begin{tabular}{ll}
\hline Métodos quantitativos & Métodos não-quantitativos \\
\hline • Métodos informais & $\bullet$ Procedimento analítico geral \\
• Métodos formais & $\bullet$ Mapeamento cognitivo \\
- Análise de conteúdo & $\bullet$ Exposições de dados \\
- Grade de repertório & $\bullet$ Teoria fundamentada \\
& $\bullet$ Método quasi-judicial \\
\hline
\end{tabular}

Fonte: COLLIS; HUSSEY; 2005, p. 238.

Para Yin (2010), toda a análise do estudo de caso deve seguir uma estrutura analítica geral, definindo prioridades para o que analisar e por quê. $\mathrm{O}$ autor sugere quatro estratégias de análise, que podem ser utilizadas individualmente ou em conjunto: (1) contar com as proposições teóricas; (2) desenvolver descrições de caso; (3) usar dados quantitativos e qualitativos e (4) examinar as explanações rivais.

De forma geral, as avaliações qualitativas das pesquisas são caracterizadas pela descrição, compreensão e interpretação de fatos e fenômenos, em contrapartida à avaliação quantitativa, em que predominam as mensurações (MARTINS; THEÓPHILO, 2007).

Por fim, os modelos de análise mais usados, segundo Yin (1989, apud BRESSAN, 2000) são: (1) padrão combinado - compara padrões com base empírica com os padrões previstos; (2) elaboração de explicações - o objetivo é o de analisar o estudo de caso para elaborar explicações sobre o caso e se constitui de uma acurada relação com os fatos do caso, considerações sobre as explicações alternativas e conclusões baseadas nas explicações que pareçam mais congruentes com os fatos e (3) análise de séries temporais.

Martins (2008) defende que a análise de um estudo de caso deve deixar claro que todas as evidências relevantes foram abordadas e deram sustentação às proposições que parametrizaram toda a investigação. $\mathrm{O}$ autor afirma ainda que a qualidade das análises será notada pelo tratamento e discussão das principais interpretações - linhas de argumentação concorrentes, bem como pela exposição dos aspectos mais significativos do caso sob estudo e de possíveis laços com outras pesquisas assemelhadas.

Finalmente, de acordo com Campomar (1991), no estudo de casos as análises deverão ser feitas principalmente por analogias, contendo comparações com teorias, modelos e outros casos. As conclusões deverão ser específicas, com possíveis inferências (não estatísticas) e 
explicações permitindo que as generalizações sejam usadas como base para novas teorias e modelos.

Neste estudo, a análise dos dados será realizada ao longo dos dois seguintes, da apresentação de resultados do caso às conclusões da pesquisa. Os resultados serão apresentados em uma estrutura analítica linear, iniciando com uma breve apresentação da empresa em questão, a Vivo. Será então apresentado o contexto em que o caso se desenvolve, em uma composição de dados primários (dados categorizados das entrevistas) e de dados secundários (documentos coletados ao longo dos processos de entrevistas, incluindo dados de séries temporais).

Posteriormente, o fenômeno peculiar do caso será enfocado, agregando as visões específicas de cada unidade de análise. Ao final, o modelo conceitual de pesquisa construído a partir da fundamentação teórica será confrontado com os dados gerais coletados, estabelecendo comparações por meio de inferências e analogias, além da apreciação de possíveis teorias rivais. 


\section{APRESENTAÇÃO DE RESULTADOS: O CASO VIVO}

\subsection{Apresentação da empresa: breve contexto de formação da Vivo S/A}

Para fins práticos, apresenta-se na ilustração 24 uma linha do tempo, em que é resumida a evolução do setor em que estão inseridos Vivo e suas concorrentes, destacando as principais mudanças competitivas, tecnológicas e regulatórias de forma a se avançar ao evento-foco de estudo deste caso.
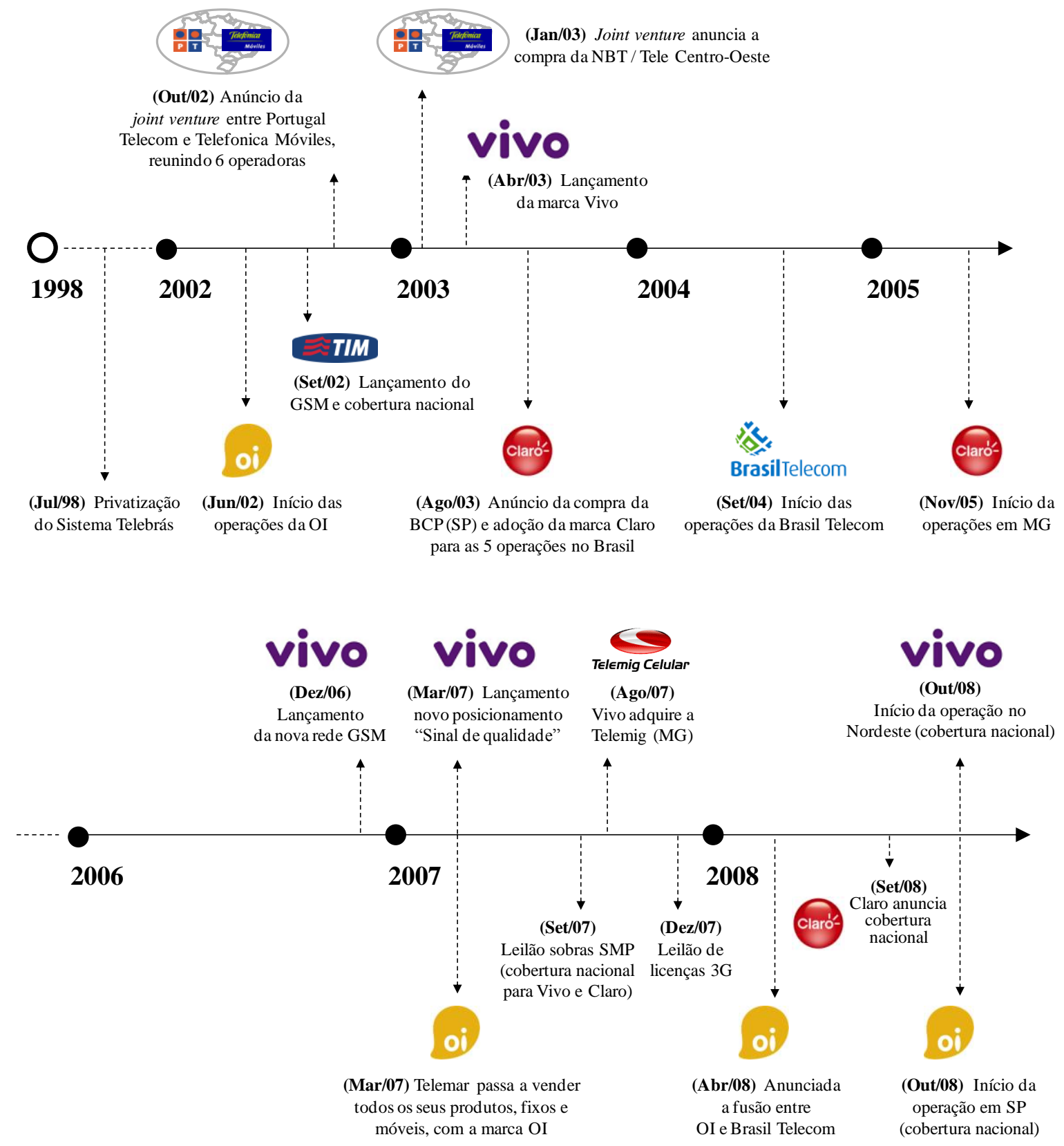

Ilustração 24 - Histórico do mercado de telecomunicação móvel no Brasil 1998 -2008 Fonte: Material interno da empresa, adaptado pelo autor 
Numa rápida retrospectiva, o Brasil iniciou a oferta dos primeiros serviços de telefonia celular no ano de 1990, quando começaram a operar os serviços na capital federal, Brasília, e no Rio de Janeiro, ainda no tempo do monopólio estatal da Telebrás. O grande fator de aceleração do celular no Brasil ocorre a partir de 1998, por força de três fatores: (1) a privatização total das telecomunicações no país; (2) o aumento da competição; e (3) subsídio de aparelhos e financiamento adequado por parte das operadoras e do comércio.

Mas uma das estratégias mais bem sucedidas de expansão da telefonia celular no Brasil foi a introdução do pré-pago, em 1999, permitindo que usuários de baixa renda pudessem prever e controlar seus gastos. Neste cenário, para viabilizar esse objetivo, foi preciso que as operadoras desenvolvessem estratégias específicas, desde a realização de ofertas de aparelhos com custo muito baixo, juntamente com pacotes de serviços acessíveis ao usuário de menor renda. A competição acirrada levou as operadoras a subsidiar os aparelhos em algumas promoções em que o aparelho passava inclusive a ser gratuito, mediante assinatura de contratos de fidelidade de 12 meses.

Tais estratégias passaram a ser combinadas inclusive com ofertas mais agressivas de valor agregado, na outra extremidade do mercado, às corporações e aos assinantes de maior renda, de modo a elevar a receita média dos clientes pós-pagos.

Em abril de 2003, a Vivo S/A, uma empresa de serviços de telecomunicações com atuação no Brasil, é constituída a partir de uma joint venture entre as empresas Telefónica Móviles e Portugal Telecom. A Vivo formou-se de fato a partir da junção das operações de sete empresas (controladas por Telefónica Móviles e Portugal Telecom), líderes de mercado nas respectivas áreas em que atuavam.

O mapa da ilustração 25 apresenta as empresas que deram origem à Vivo S/A e as respectivas áreas de atuação no Brasil. Cabe destacar que à época, a empresa não atuava comercialmente no Estado de Minas Gerais (área 4) e em parte da região Nordeste, nos Estados do Piauí, Ceará, Rio Grande do Norte, Paraíba, Pernambuco e Alagoas (área 10). A prestação de serviço da operadora nestas áreas era realizada através de acordos de roaming nacional junto às outras operadoras atuantes no país. 


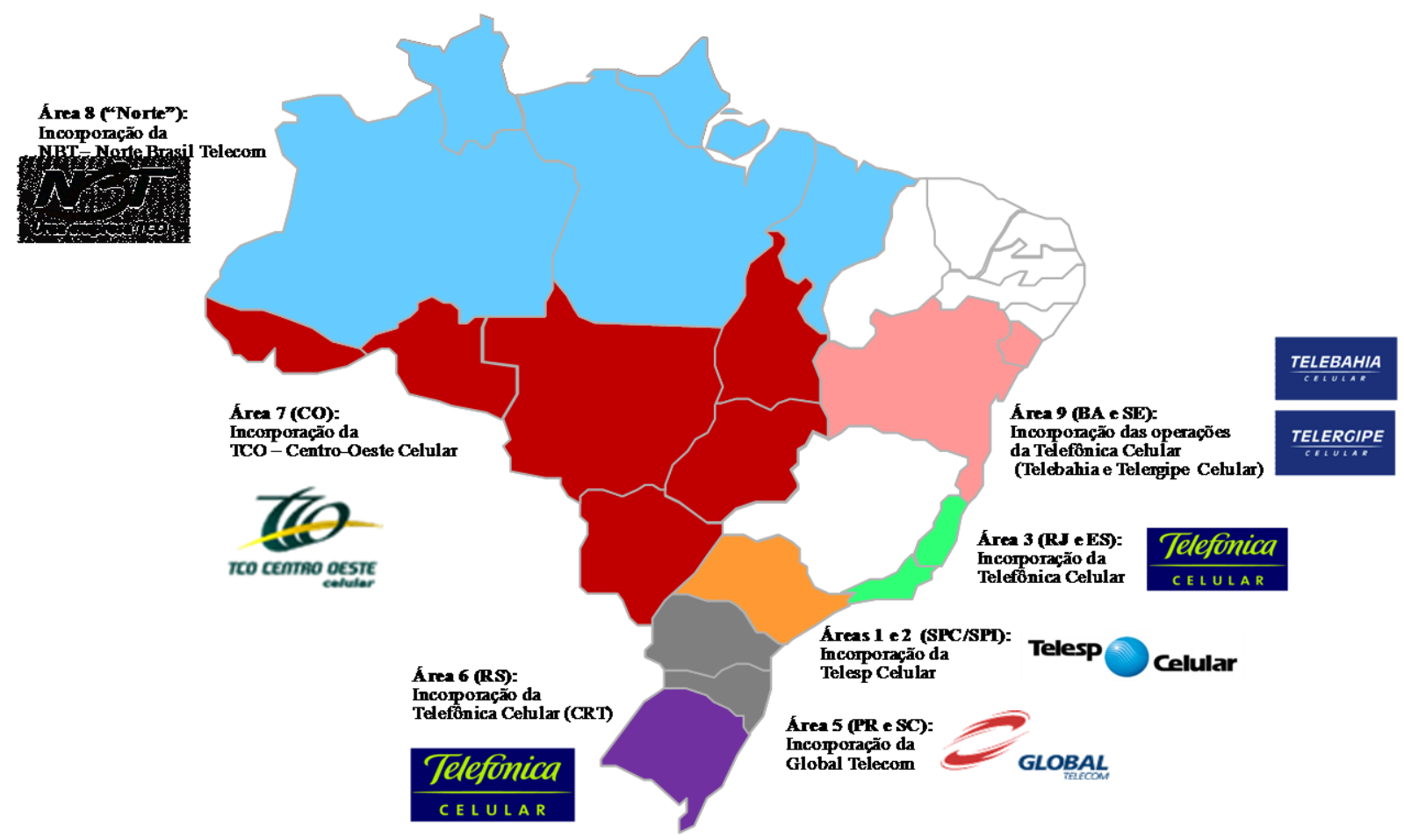

Ilustração 25 - Operadoras formadoras da empresa Vivo como joint venture

Fonte: Material interno da empresa, adaptado pelo autor

A criação da marca Vivo representou uma consolidação dos modelos comerciais adotados em todo o país numa estratégia comercial comum, substituindo as diferentes marcas sob as quais as diferentes empresas ofereciam seus serviços em seus respectivos Estados. O lançamento da marca foi acompanhado por programas de fidelização e outras medidas visando contribuir para o sucesso da estratégia comercial. Guiada por uma equipe de administração em comum, diversas iniciativas de marketing foram planejadas, adequando atividades aos seus mercados em particular.

Em paralelo, para unificação da operação comercial da empresa durante o período de cerca 5 anos, até meados de 2006, foram colocados em prática diversos projetos chamados "estruturantes", de forma a unificar sistemas e atividades de cadastro, atendimento e faturamento ("billing"), além de plataformas sistêmicas de gerenciamento de ofertas e recargas, dado que cada operação originalmente trabalhava com um sistema próprio ("legado").

Entre os principais produtos e serviços ofertados pela operadora à época estão:

- Serviços de voz: planos, bônus e/ou pacotes de minutos na modalidade de pagamento pós-pago (conta) ou pré-pago (recarga); 
- Serviços de banda larga: planos e/ou pacotes de conexão em internet móvel para smartphones, notebooks e desktops;

- Serviços de valor agregado: são serviços complementares aos serviços de voz e de banda larga; incluem facilidades à conexão tais como: caixa postal, mensagens de texto/de vídeo, mensagens informativas, localização baseada em GPS, proteção à navegação em internet, seguros de aparelhos, entre muitos outros;

- Venda de aparelhos celulares, smartphones e modens: venda de aparelhos destinados à conexão de voz, dados e/ou internet, comercializados com desconto/subsídio da operadora de forma escalonada à contratação de diferentes níveis de planos de voz e/ou banda larga.

$\mathrm{Na}$ indústria de telecomunicações móvel uma questão muito relevante é a tecnologia de rede adotada para a prestação do serviço, que influencia não só na qualidade do serviço mas também na estratégia comercial no que diz respeito à oferta de terminais (aparelhos celulares, modens, placas) e de serviços agregados. A ilustração 26 identifica os tipos de tecnologia utilizados nas diversas operações regionais da Vivo no período seguinte à unificação da empresa.

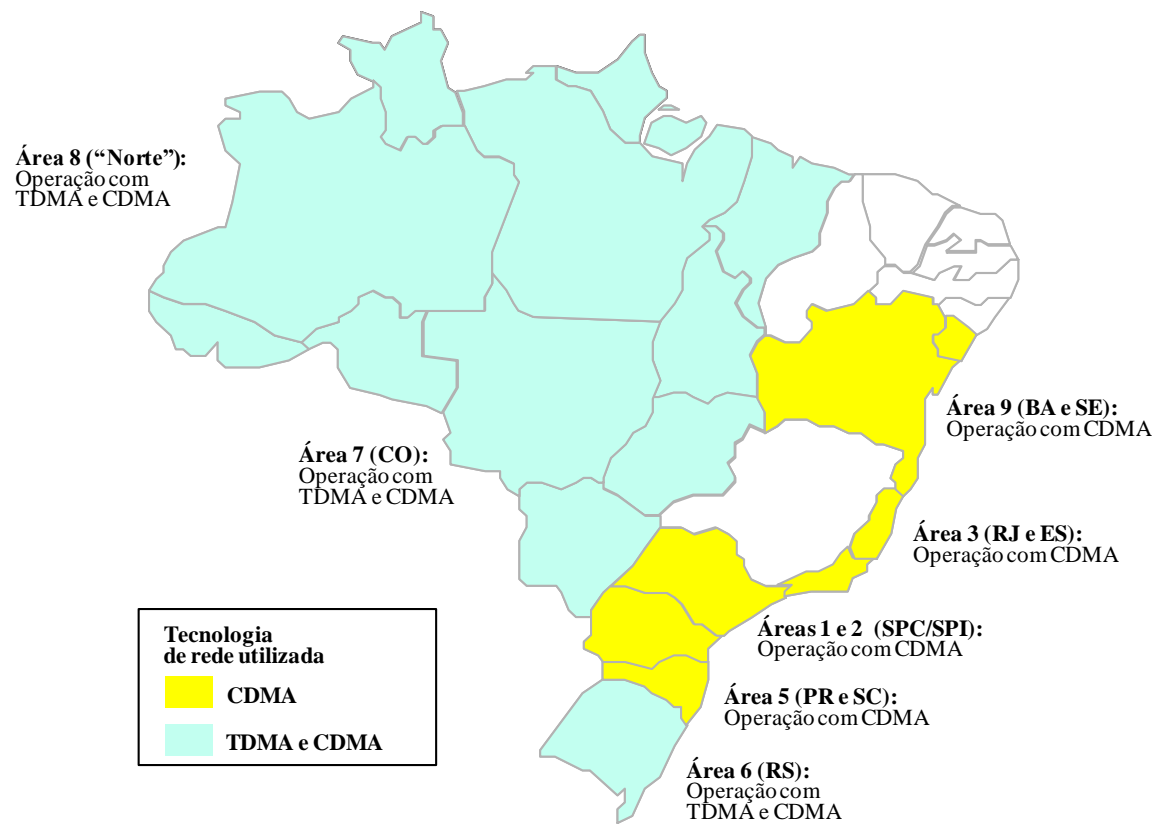

Ilustração 26 - Tecnologias de rede utilizadas pela Vivo logo após o lançamento Fonte: Material interno da empresa, adaptado pelo autor 
Como se pode perceber pelo mapa, o CDMA (Code Division Multiple Access) foi escolhido pela empresa para se tornar a tecnologia unificada de atuação no Brasil. Antes da formação da joint venture, algumas operações inicialmente optaram pela tecnologia TDMA (Time Division Multiple Access), uma tecnologia considerada mais antiga e menos eficiente que as tecnologias dominantes àquele momento: o CDMA e o GSM (Global System for Mobile Communication), utilizado pelas demais concorrentes (Claro, TIM, Oi e Brasil Telecom). Por esse motivo, o desafio inicial de Vivo foi realizar a virada de tecnologia ("overlay") de TDMA para o padrão CDMA nas áreas 6, 7 e 8 (Rio Grande do Sul, Centro-Oeste e Norte).

\subsection{Breve histórico de marca e posicionamento}

A seguir, a partir da documentação reunida junto à empresa Vivo e de outras fontes secundárias (textos públicos, relatórios de administração, materiais de publicidade fornecidos pela empresa e também obtidos através de ferramentas de acesso privado, como o Arquivo da Propaganda), apresenta-se, do ponto de vista de marca e de posicionamento, a evolução da Vivo desde o seu lançamento até o momento do evento-foco de análise. Tal análise se faz importante para a correta compreensão da identidade de marca desejada junto ao mercado e como a imagem de marca evoluiu ao longo desse tempo, culminando com a mudança de posicionamento que se objetiva entender.

Segundo as diretrizes estratégicas da marca, o nome Vivo foi escolhido para traduzir a postura informal, relevante e direta da empresa. O jeito de falar da marca reflete a vida e a espontaneidade: a forma de se relacionar coloquial, simples, surpreendente e brasileira. A marca é composta de um logotipo e um ícone.

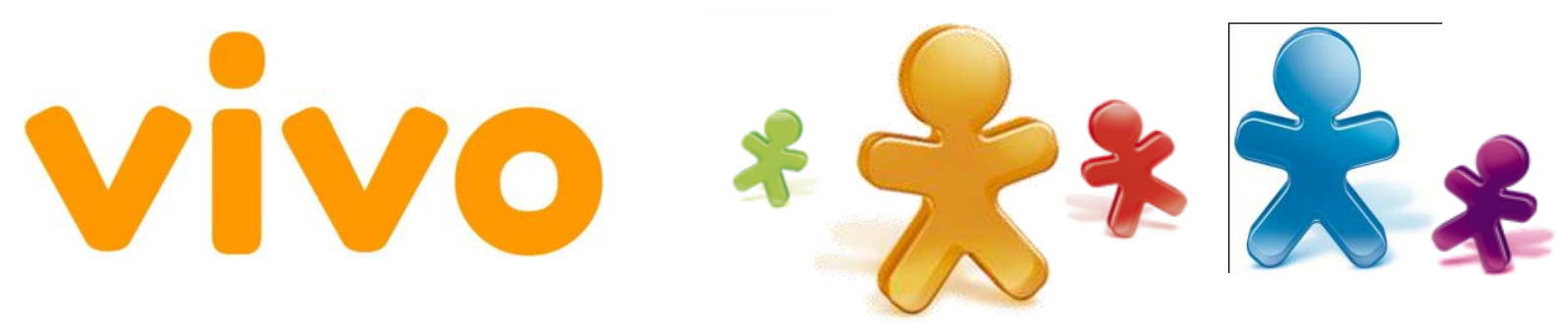

Ilustração 27 - Logo e ícones constituintes da identidade de marca Vivo

Fonte: Material interno da empresa, adaptado pelo autor

O ícone personifica a companhia, a tecnologia e os serviços oferecidos, tornando a imagem da marca mais tangível e humana. O ícone da marca não tem sexo definido e representa toda a 
diversidade de pessoas do país: é utilizado em 5 cores diferentes e tem o objetivo de criar um forte componente emocional na comunicação, aproximando as pessoas da Vivo.

A visão da marca, à época de seu lançamento em 2003 era constituída por três afirmações complementares: (1) Ser a maior comunidade de clientes do Brasil; (2) Ser uma marca amada, energética e inovadora; (3) Ser uma marca convidativa e que envolve a todos na mais atraente comunidade do Brasil.

A seguir apresenta-se um histórico de evolução da marca no período compreendido entre 2003 a 2007, para que se possa compreender melhor o período em que evento-foco de estudo se desenrola. Serão apresentadas "fichas" que resumem o foco de atuação da marca por meio de produtos e comunicação. Estes documentos foram disponibilizados pela área de marketing da empresa, na etapa de pesquisa documental.

Em 2003, a marca Vivo foi lançada sob a assinatura de posicionamento "Vivo. É você em primeiro lugar". O foco de diferenciação, denotado fortemente através das campanhas publicitárias e discurso nos diversos pontos de contato com o cliente, estava centrado na liderança da empresa, que contava com a maior comunidade de clientes (do Brasil e do hemisfério sul), além de ter a maior cobertura de rede dentre as operadoras celulares à época.

\section{3: Lançamento da marca Vivo \\ A marca Vivo foi lançada com uma proposta de posicionamento baseada na dimensão. \\ - A maior operadora do Hemisfério Sul \\ - A maior cobertura do Brasil \\ - A maior comunidade de celulares \\ Assinatura: \\ Vivo. É você em primeiro lugar.
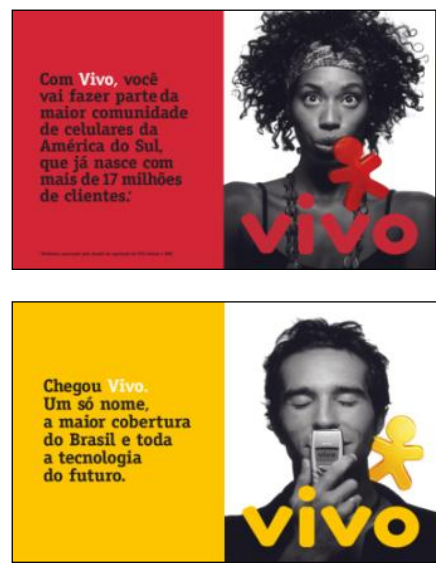 \\ Foco \\ Liderança / Comunidade}

Ilustração 28 - Foco de atuação da marca Vivo em 2003

Fonte: Material interno da empresa 
Entre os anos de 2004 e 2005, a marca Vivo tem a sua atuação fortemente destacada pelo foco na diferenciação por meio da tecnologia e inovação. Neste período a atividade comercial foi marcada por um grande número de lançamentos de serviços de valor agregado, com uma supervalorização da tecnologia como fator de superioridade. Na comunicação, o apelo de modernidade e exclusividade foi amplamente explorado com o uso de celebridades (a top Gisele Bündchen, a modelo Naomi Campbell, o jogador Robinho, a atriz Carolina Dieckmann, entre outros). Neste período manteve-se o uso da assinatura de posicionamento "Vivo. É você em primeiro lugar".

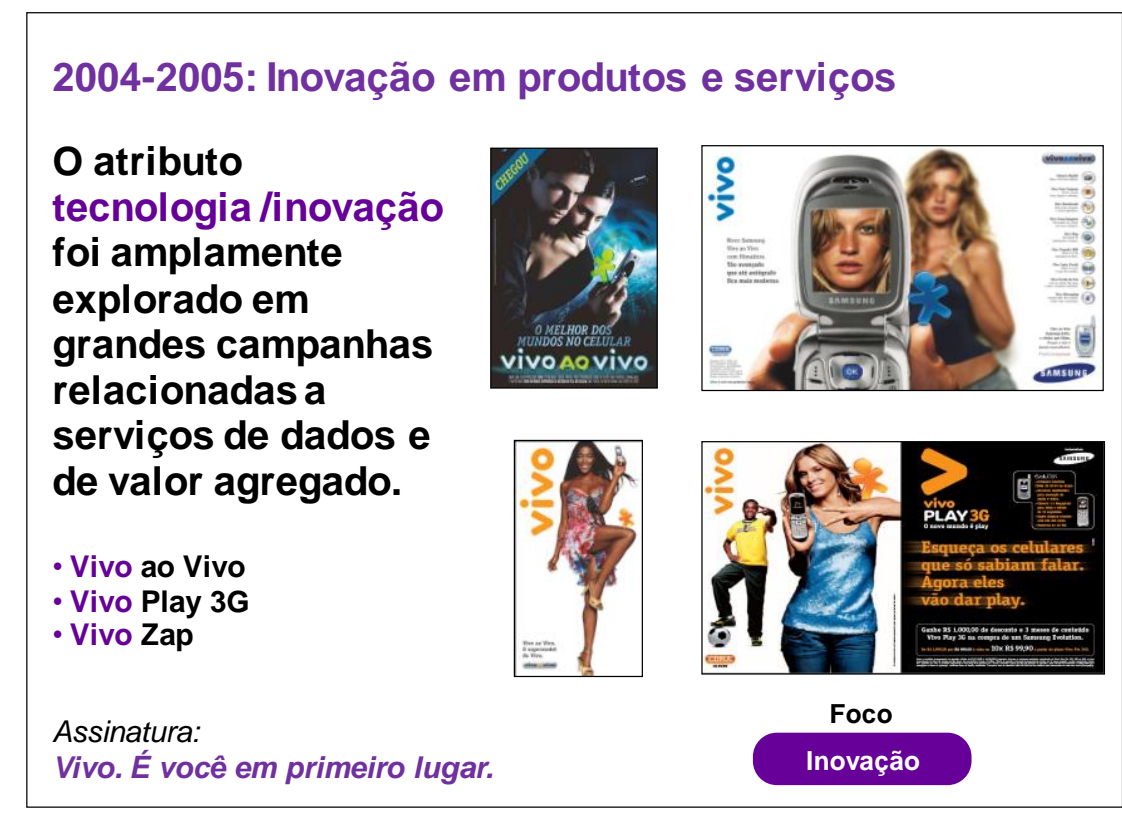

Ilustração 29 - Foco de atuação da marca Vivo em 2004-2005 Fonte: Material interno da empresa

O esquema da ilustração 30 demonstra a forma pela qual a empresa buscava desenvolver seu posicionamento à época. O primeiro objetivo referia-se a reforçar o link emocional com o cliente ("Vivo. É você em primeiro lugar). O segundo, em fortalecer os principais atributos desejados (Cobertura/Qualidade de Rede, Liderança/Credibilidade, Serviços com tecnologia e inovação e Valor/Preço justo). Por fim, objetivava-se unificar a proposta de valor, reforçando a vantagem de possuir a maior comunidade de clientes. 


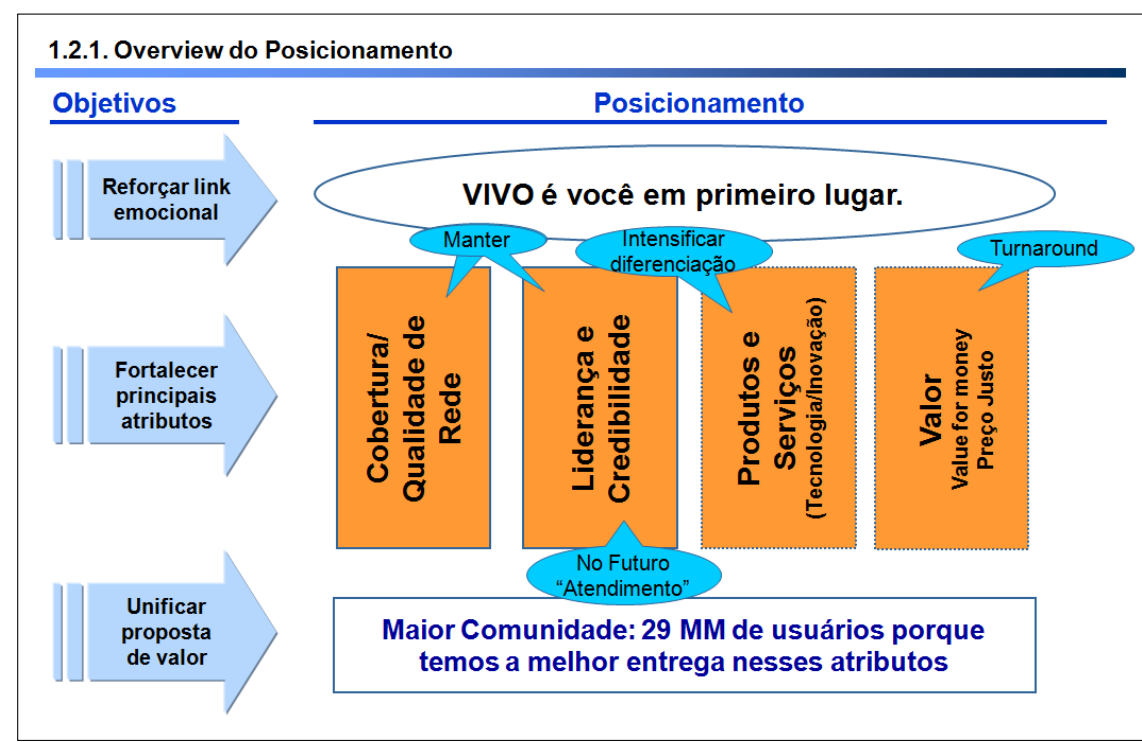

\section{Ilustração 30 - Visão do posicionamento Vivo e objetivos em 2005}

Fonte: Material interno da empresa

Vale destacar os esforços de comunicação específicos realizados pela operadora neste período em torno da promoção da tecnologia CDMA. Em diversas oportunidades foram realizadas campanhas que destacavam os diferenciais e a superioridade da tecnologia no tocante à qualidade de ligação e velocidade de transmissão de dados. A ideia era apresentar a tecnologia CDMA como a tecnologia do futuro, também adotada nos principais mercados mundiais, como Coréia do Sul, Estados Unidos e China.

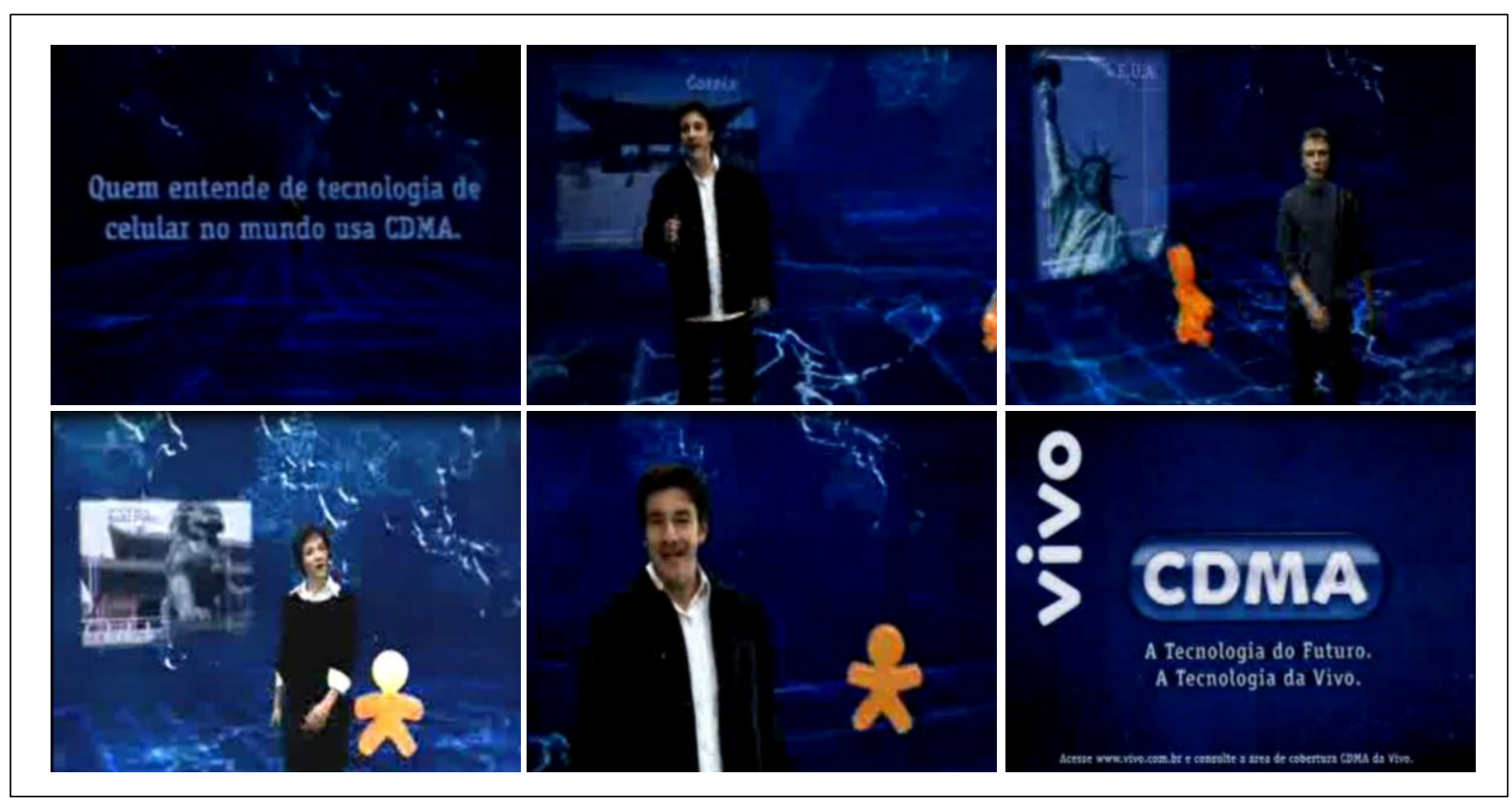

Ilustração 31 - Campanhas de comunicação Vivo, de promoção da tecnologia CDMA Fonte: Arquivos eletrônicos disponibilizados pela empresa, adaptados pelo autor 
Nesta campanha, a operadora Vivo desenvolveu três comerciais em que cada um deles aludia à tecnologia CDMA como a principal em cada um desses mercados. As imagens apresentadas resumem os três comerciais e denotam o caráter tecnológico da comunicação, que iniciava sempre com a locução e frase: "Quem entende de tecnologia no mundo, usa CDMA". Para cada um dos 3 comerciais a locução seguia com: "Na Coréia, um dos países que mais produz celulares, a tecnologia é CDMA"; "Nos Estados Unidos, um dos países mais avançados do planeta, a tecnologia líder é CDMA"; "Na China, que é a nova potência econômica, a tecnologia que não para de crescer é CDMA”. Por fim cada comercial finalizava com a frase "CDMA: a tecnologia do futuro, a tecnologia da Vivo".

Além disso, durante todo esse período em todas as peças de comunicação a Vivo aplicou um selo indicativo do CDMA como a tecnologia da Vivo (e do futuro), de forma a endossar as ofertas comerciais, conforme exemplificado na ilustração 32.

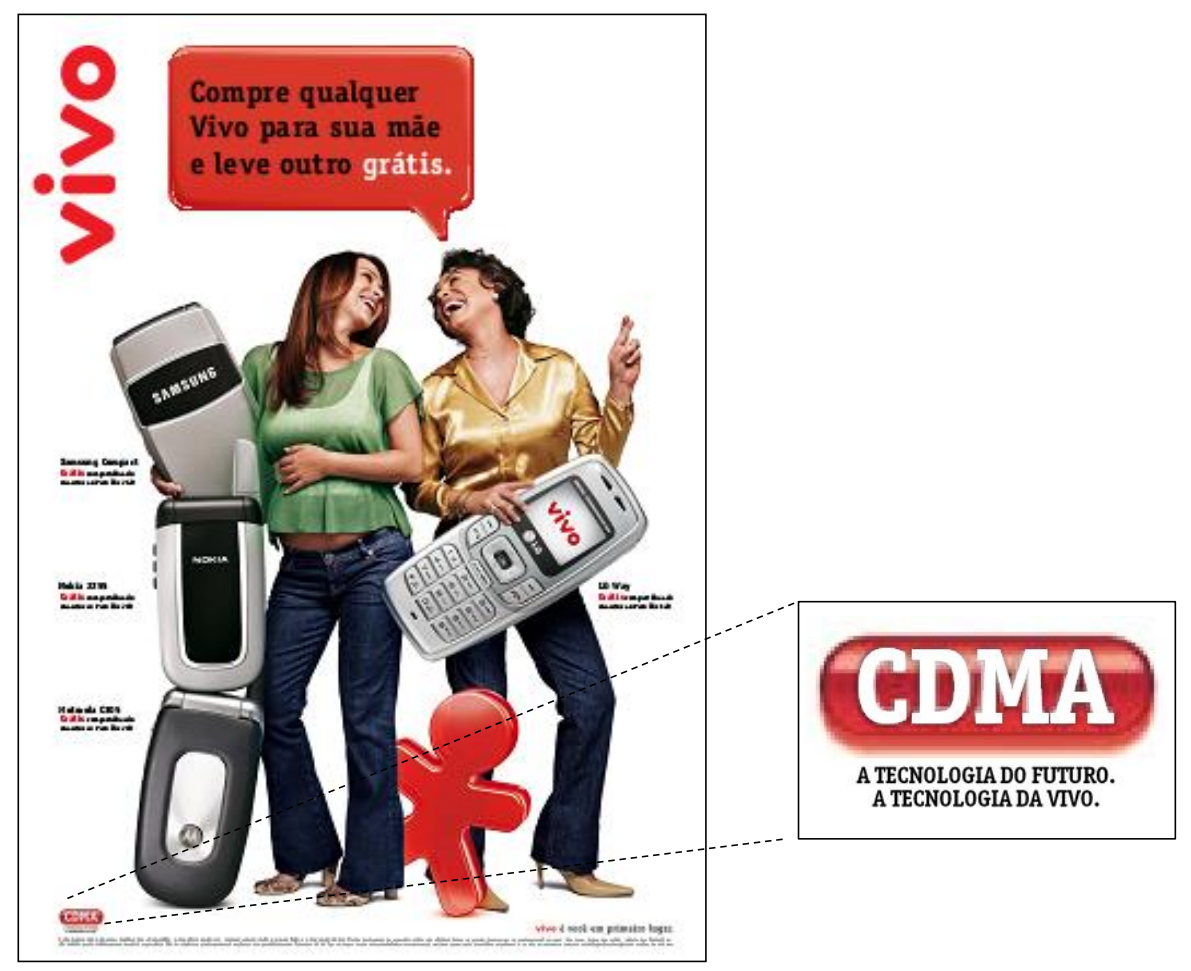

Ilustração 32 - Exemplo de aplicação do selo CDMA na comunicação Vivo Fonte: Material interno da empresa, adaptado pelo autor

A partir de meados de 2006, a consciência de que os clientes passam a conferir maior importância a atributos mais básicos da prestação de serviço (tais como qualidade e preço), força a marca Vivo a rever sua estratégia. Neste período, Vivo inicia a introdução de uma nova rede baseada em tecnologia GSM, cujo processo será analisado em detalhe no tópico a 
seguir. Em 2007, Vivo passa de fato por um reposicionamento de marca e a assinatura de posicionamento passa a ser "Vivo. Sinal de qualidade."

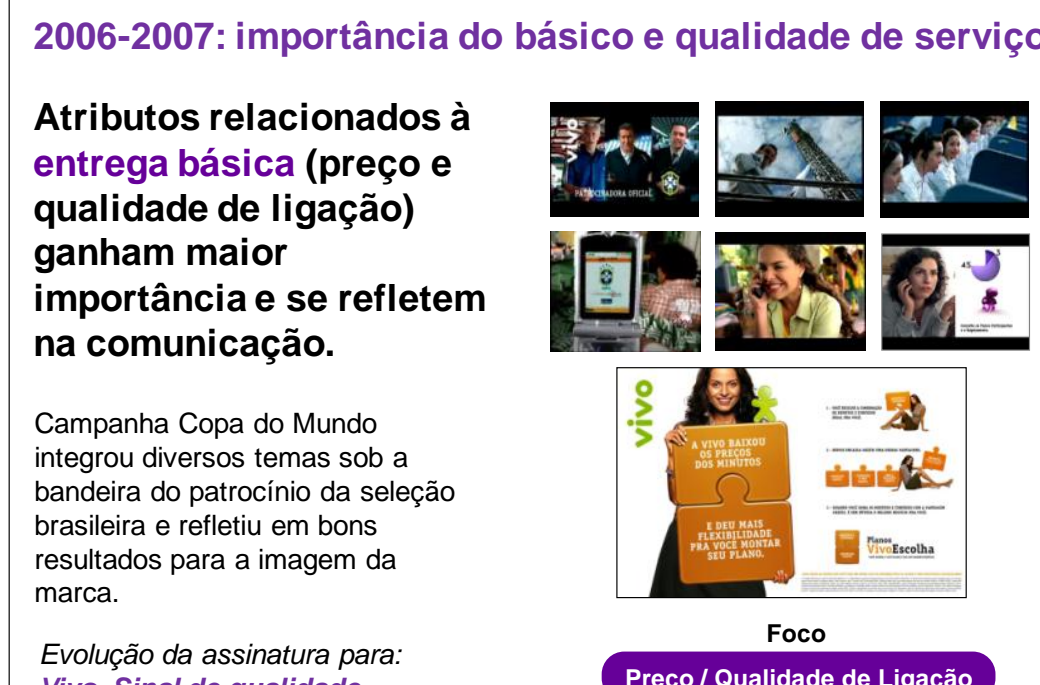

Vivo. Sinal de qualidade.
Preço / Qualidade de Ligação

Ilustração 33 - Foco de atuação da marca Vivo em 2006-2007

Fonte: Material interno da empresa

No quadro 18 resume-se a evolução das assinaturas de posicionamento da marca Vivo ao longo do tempo, junto à evolução de tecnologias de rede empregadas. Aponta-se então o momento exato em que se situa o evento-foco de estudo do trabalho, em que se verifica, de forma concomitante, a mudança de posicionamento de marca e de tecnologia de rede utilizada na prestação do serviço.

Quadro 18 - Evolução do posicionamento de marca e tecnologias Vivo

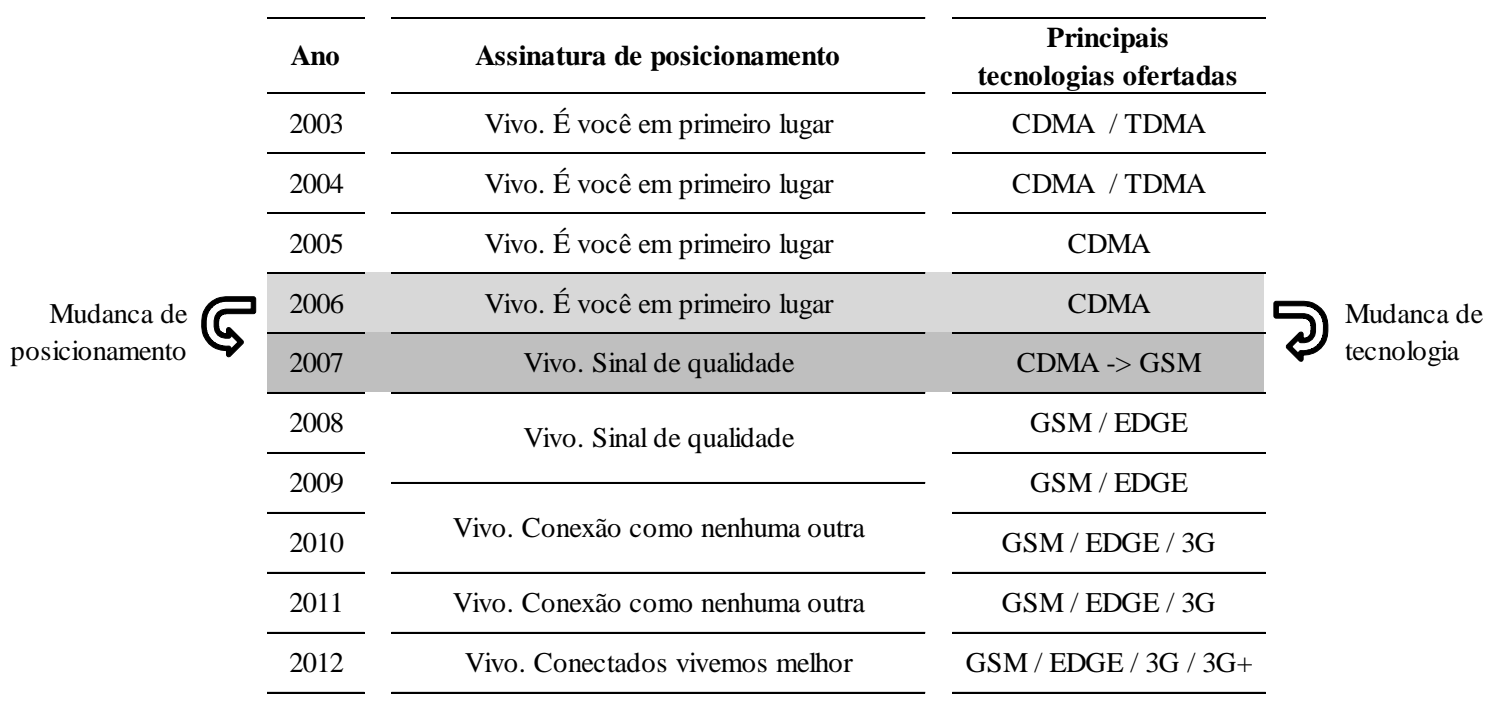

Fonte: Criado pelo autor 
Por fim, de forma análoga e resumida, cabe apresentar, na ilustração 34, o foco de atuação e evolução das assinaturas de posicionamento dos principais concorrentes de Vivo no mesmo período analisado.

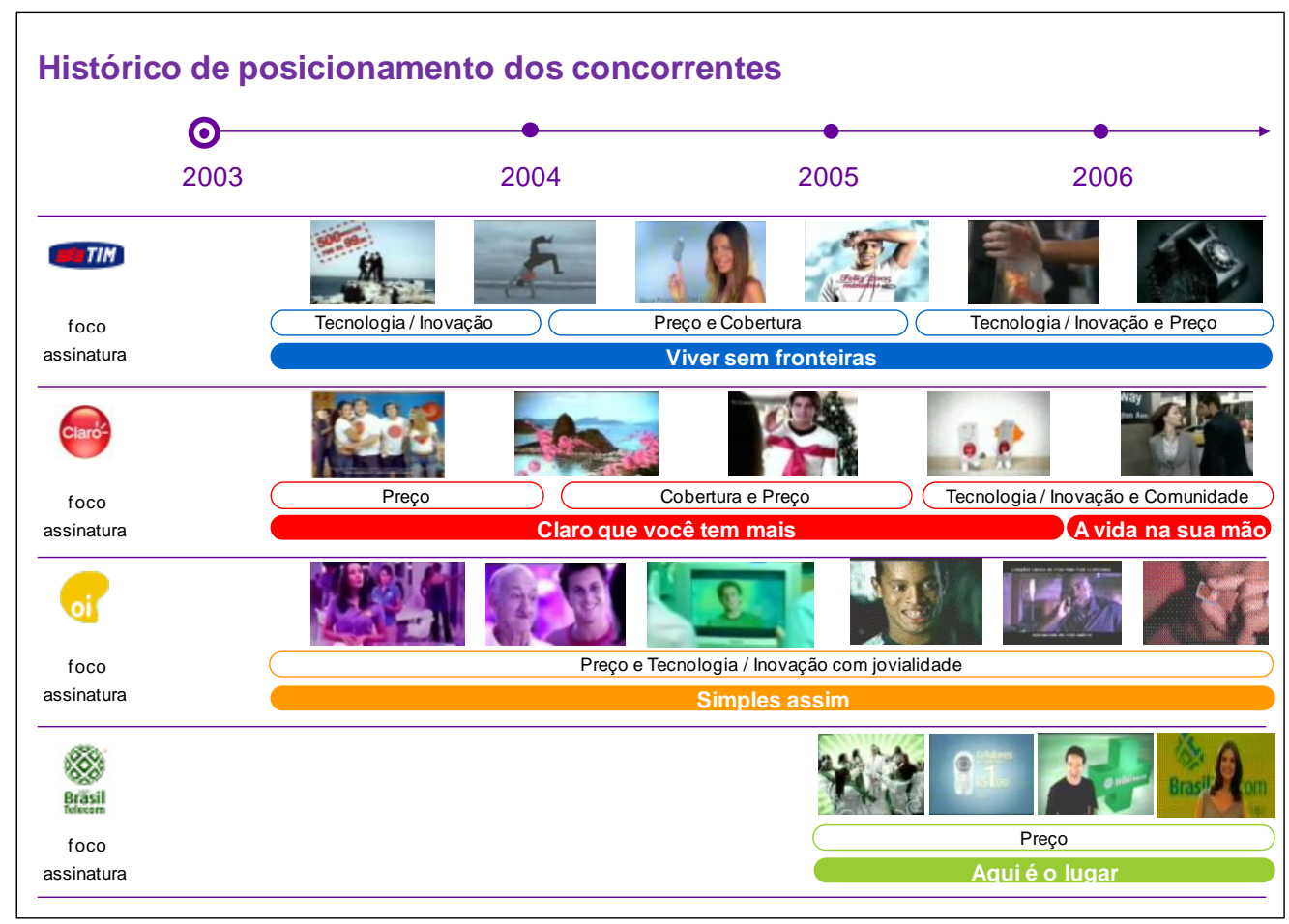

Ilustração 34 - Foco de atuação das marcas concorrentes, entre 2003 e 2007

Fonte: Material interno da empresa

É relevante destacar a linearidade de atuação da marca TIM no período, mais focada junto aos clientes de mais alto valor, reforçando prioritariamente os atributos de tecnologia e inovação, muitas vezes por meio do argumento da tecnologia GSM. A marca TIM utilizou a assinatura "Viver sem fronteiras" durante todo o período. Claro teve sua atuação bastante marcada pelo foco nos atributos de cobertura e preço, com ofertas agressivas. A marca passou por um reposicionamento num período próximo ao de Vivo (ano de 2006), num momento em que passa a focar clientes de mais alto valor e maior destaque para $\mathrm{o}$ atributo de tecnologia/inovação. Neste processo, a assinatura de marca passou de "Claro que você tem mais" para "Claro. A vida na sua mão". Oi e Brasil Telecom são operadoras que à época apresentavam uma atuação mais regionalizada e tinham atuação baseada basicamente em promoções e preço baixo. Oi se destacava ainda por um diferencial de jovialidade de marca, utilizando a assinatura de posicionamento "Simples assim". 


\subsection{Contexto: condicionantes para o evento-foco}

Neste tópico pretende-se apresentar o contexto referente ao período 2006-2007, identificando os condicionantes para o evento-foco. Esta visão de contexto foi desenvolvida a partir da composição dos principais pontos relatados pelos executivos entrevistados (com base nas questões identificadas como "Parte 2" do roteiro de entrevistas), além dos documentos internos que puderam ser coletados e analisados. As categorias de temas tratados neste segmento refletem um agrupamento de dados realizados a partir das entrevistas e representa os condicionantes mais relevantes, abordados, em maior ou menor grau, por todos os entrevistados.

\section{Estrutura e direção}

Esta contextualização, parte do ambiente interno da empresa, com o detalhamento do organograma da Vivo à época em que o estudo de caso se passa. São apresentadas as áreas de primeiro nível, diretamente ligadas à presidência. A empresa era composta por três vicepresidências executivas - de Marketing e Inovação, de Operações e de Finanças, Planejamento e Controle, por duas vice-presidências - uma de Regulamentação e Interconexão e outra de Redes, além de outras sete diretorias que completam o primeiro nível de comando.

Apresenta-se aqui também o segundo nível de comando especificamente para as vicepresidências de Marketing e Inovação e de Operações (diretorias apresentadas em linhas tracejadas), pois são relevantes para o escopo deste estudo de caso. A partir destas diretorias foram executadas a maior parte das ações que serão estudadas mais profundamente neste trabalho.

É imprescindível sublinhar que a empresa havia atravessado muito recentemente uma mudança de comando, com a vinda do executivo Roberto Lima, ex-presidente da Credicard, como novo presidente da empresa, em substituição ao português Francisco Padinha, presidente da empresa desde seu lançamento em 2003 (FUSCO; BRAUN, 2005).

O organograma apresentado na ilustração 35 contempla as considerações até aqui realizadas e representa a equipe sob a liderança do presidente Roberto Lima durante os anos de 2006 e 2007. 


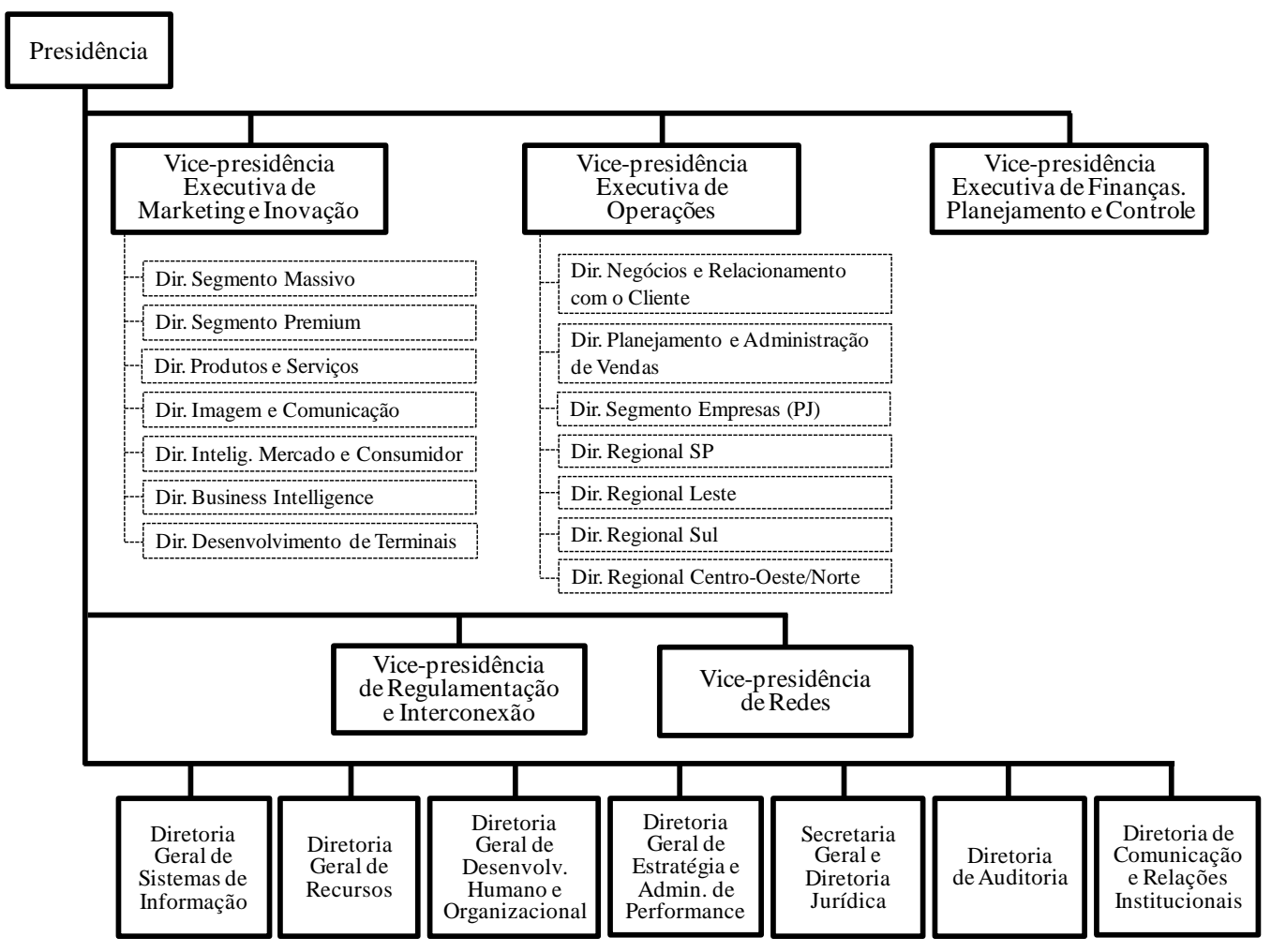

Ilustração 35 - Organograma Vivo em 2006-2007

Fonte: Material interno da empresa, adaptado pelo autor

\section{Desempenho operacional e financeiro}

Do ponto de vista de resultados, a empresa enfrentava um histórico recente de resultados negativos. Desde a formação da empresa sob uma mesma marca, Vivo, a tendência nos resultados operacionais (share de mercado) e financeiros (share de receita) foram de queda progressiva, como se pode perceber nos gráficos a seguir.

Gráfico 08 - Evolução de parque e share de mercado Vivo, de 2003 a 2006
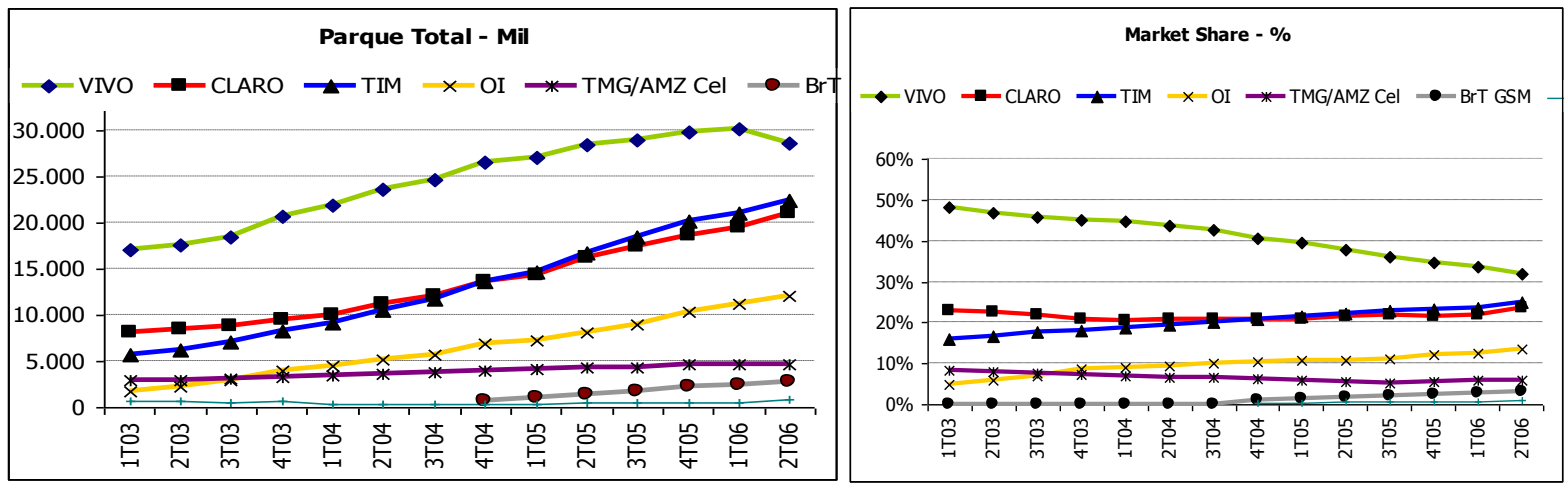

Fonte: Relatório de administração da empresa, adaptado pelo autor

Embora o número total de linhas de Vivo ("parque") tenha aumentado de forma significativa no período (de um patamar de 17 milhões de linhas em 2003, para cerca de 29 milhões em 
meados de 2006), o share de mercado mostra uma linha declinante (de um expressivo patamar de quase $50 \%$ do mercado para pouco mais de $30 \%$ em 2006).

Gráfico 09 - Evolução de receita e share de receita Vivo, de 2003 a 2006

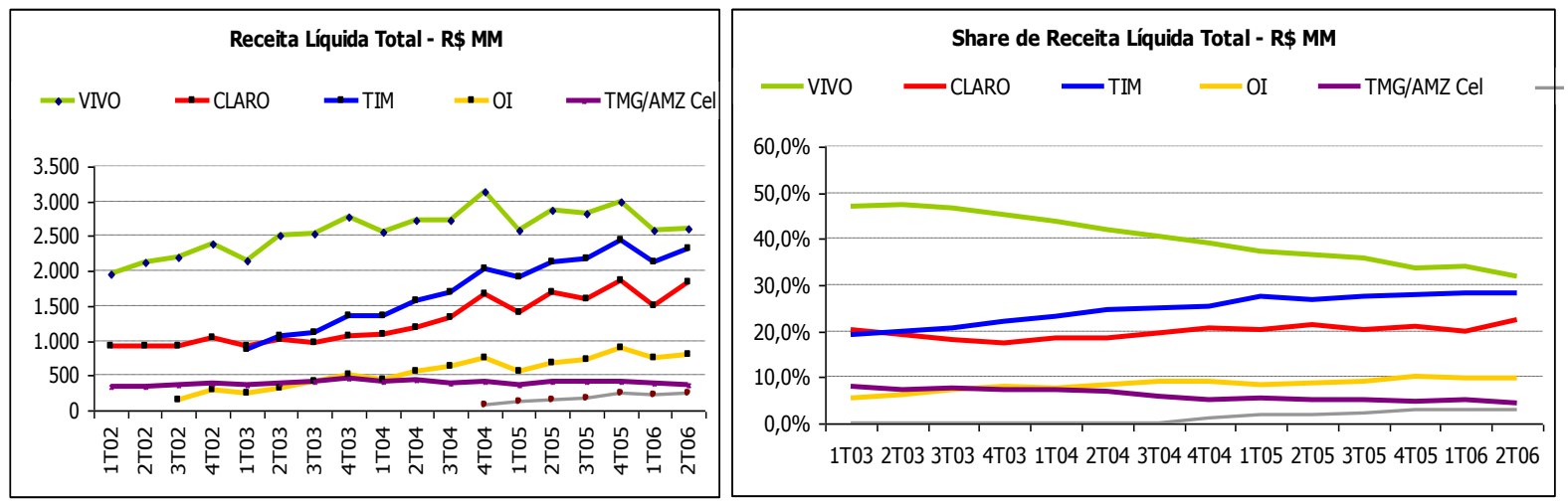

Fonte: Relatório de administração da empresa, adaptado pelo autor

Em tendência semelhante, a receita líquida total da empresa aumenta no período (de um patamar de cerca de 2 bilhões de reais em 2003, para pouco mais de 2,5 bilhões de reais em meados de 2006), porém o share de mercado também apresenta-se sob a forma de uma linha declinante (de cerca de 50\% de share de receita para pouco mais de $30 \%$ em 2006).

\section{Implicações tecnológicas}

O cenário competitivo se desenhava cada vez mais acirrado à época, com uma evolução muito forte dos concorrentes principais, segundo os entrevistados, as marcas TIM, Claro e Oi. Mencionam-se ainda dois relevantes entraves à atuação de Vivo à época, que podem ser relacionados à questão tecnológica: a clonagem e o preço de aparelhos.

A clonagem foi um dos episódios mais complexos para a Vivo na opinião da maioria dos entrevistados. Na prática, segundo a Anatel, o celular clonado é um aparelho que foi reprogramado para transmitir o código do aparelho e o código do assinante habilitado. Assim, o fraudador usa o aparelho clonado para fazer as ligações telefônicas e as mesmas são debitadas na conta do titular da linha.

No período de estudo do caso, um grande número de clientes da Vivo, especialmente os de mais alto valor, por serem clientes com conta (pós-pagos) estiveram sujeitos à ação de clonagem. Tecnicamente diversos estudos mostram que a ação de clonagem não está necessariamente vinculada à tecnologia e, teoricamente, ambos os tipos de tecnologia - 
CDMA e GSM - são vulneráveis à ação de clonagem, sendo mais relacionada a procedimentos operacionais do que a características intrínsecas da tecnologia empregada.

Este problema à época tomou grandes proporções e foi, segundo os entrevistados, largamente explorado pela concorrência, por meio de propaganda e de discurso nos diversos pontos de contato, como um ponto fraco da tecnologia CDMA; ou seja, realizando uma relação que não era exatamente direta. Um exemplo foi uma campanha de comunicação realizada pela Oi, que reforçou a tecnologia GSM, por ela utilizada, como possuidora de um sistema de criptografia que protege a transmissão de dados e voz pelo aparelho. A propaganda era "estrelada" por um personagem que era uma ovelha, aludindo à clonada ovelha Dolly, e prometia um aparelho celular novo e um ano de ligações grátis para o usuário que tivesse seu celular Oi clonado, denotando a confiança e segurança de sua rede GSM (GUIMARÃES, 2002).

O segundo ponto relacionado às implicações tecnológicas diz respeito ao portfólio de aparelhos. O fato de o GSM ser a tecnologia mundialmente dominante à época, naturalmente tornava o custo de comercialização de aparelhos celulares GSM mais baixo em função da escala de produção. O gráfico 10 apresenta a proporção de celulares em operação no mundo para cada tipo de tecnologia.

\section{Gráfico 10 - Evolução de celulares por tipo de tecnologia no mundo}

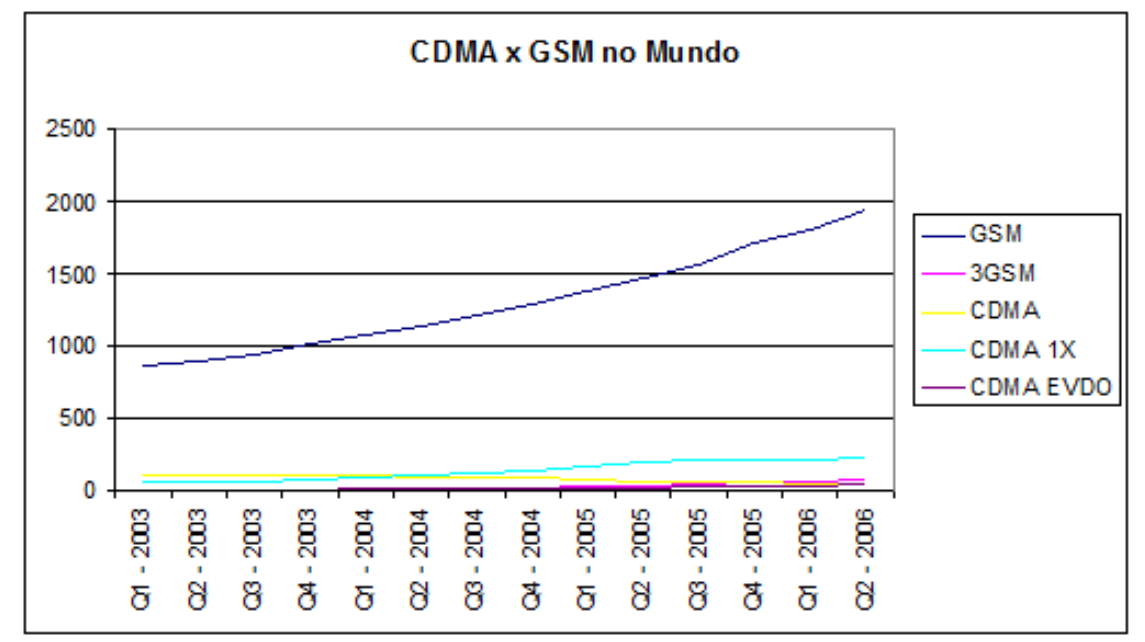

Fonte: Material interno da empresa

O portfólio de aparelhos das operadoras de celulares é costumeiramente divido em níveis de sofisticação tecnológica, segundo as funções que desempenha (desde as mais básicas, como realizar uma ligação, medianas, como operar em diversas bandas de frequiência, até as mais complexas, como possibilitar a localização geográfica do usuário, ou suportar navegação de 
dados com qualidade, que poderia ser considerada um grande diferencial à época). Assim, a oferta de portfólio de aparelhos pode ser considerada em três níveis: (1) aparelhos de "baixa gama"; (2) aparelhos de "média gama" e (3) aparelhos de "alta gama".

Segundo informações internas, o custo médio de um aparelho CDMA (considerando-se um balanceamento entre os diversos tipos de "gamas") era por volta de $12 \%$ por maior que o mesmo aparelho na tecnologia GSM. Para manter a competitividade no mercado, e considerando que a troca de aparelho celular neste mercado tornava-se cada vez mais rápida, a empresa adotou fortemente a estratégia de subsídio de aparelhos, principalmente nos aparelhos de gama baixa, em que o preço era um fator ainda mais decisivo para o cliente das classes CDE.

O diagrama da ilustração 36 sumariza e oferece um mapa cognitivo representativo das opiniões fornecidas pelos entrevistados, destacando os fatores decisivos e condicionantes para a ocorrência do evento-foco, até aqui discutidos.

Mercado de telecomunicações móveis - consumidores e empresas

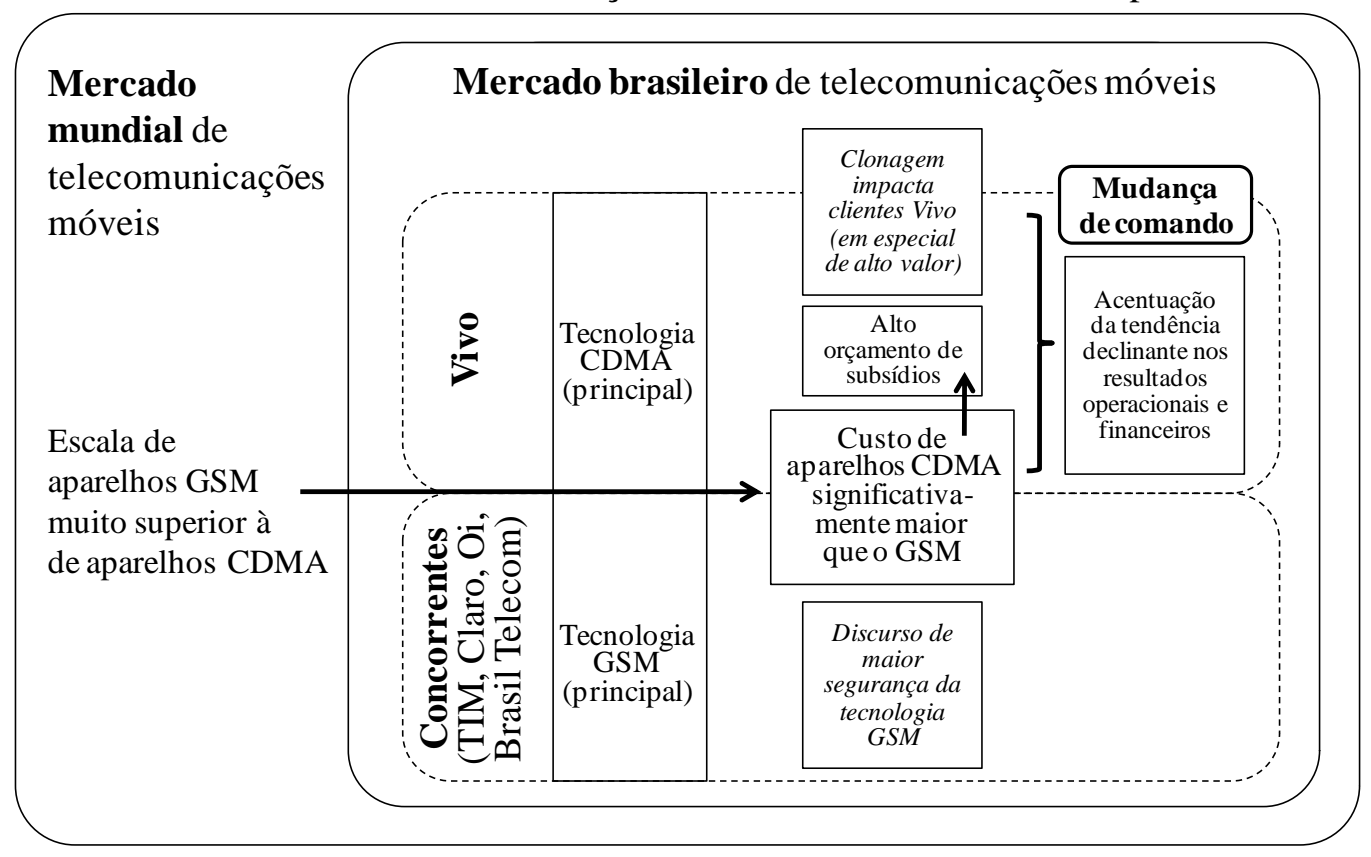

\section{Ilustração 36 - Mapa cognitivo dos fatores condicionantes para o evento-foco Fonte: Criado pelo autor}

De forma conclusiva, o mapa cognitivo apresenta, num âmbito mundial, a escala superior de aparelhos GSM como um dos condicionantes do custo de aparelhos, afetando diretamente o mercado brasileiro, o que fazia com que o custo de um aparelho CDMA (de mesmo modelo 
que um GSM) fosse maior, acarretando um esforço orçamentário significativo para Vivo no que se refere ao subsídio de aparelhos. Fatores internos como a clonagem, principalmente entre clientes de alto valor, a ocorrência de resultados declinantes de negócios e a mudança de comando podem ser considerados como aceleradores para a ocorrência do evento-foco.

\subsection{Evento-foco do caso}

O evento-foco deste estudo de caso, ou seja, o fenômeno de estudo é apresentado em detalhe neste tópico e, dado o caráter multidimensional de abordagem que se considerou para análise, ou seja, como o entorno das decisões, ações, ambiente se reconfiguraram em função de duas mudanças simultâneas em dois macro-processos: a "mudança de tecnologia" e a "mudança de posicionamento".

Importante destacar que ao longo do processo de coleta de dados primários, nomeadamente as entrevistas em profundidade com executivos, observou-se a emergência de outra vertente adicional de mudança, concomitantemente as duas "correntes" de mudanças inicialmente previstas. Para este estudo, convencionou-se denominá-la "mudança de estratégia", porém de forma geral, representa mais uma mudança de postura empresarial, resultante direta da mudança de comando no período de estudo do evento-foco.

Apesar da intrínseca relação entre cada uma dessas três grandes mudanças, para fins práticos, cada uma delas será analisada em maior detalhe em cada um dos subtópicos a seguir.

\subsubsection{Mudança de tecnologias: do CDMA para o GSM}

Conforme já anteriormente exposto, à época, as principais concorrentes da operadora Vivo no mercado brasileiro já tinham optado pela implantação do sistema digital GSM. Em termos práticos para a estratégia mercadológica, à época o sistema CDMA apresentava como características distintivas, em relação ao GSM:

- Melhor qualidade no serviço prestado: melhor qualidade de sinal, menor índice de interferências, menor queda de sinal, maior velocidade de transmissão; 
- Aparelhos sem chip: a identificação do número de usuário era realizada no próprio sistema do aparelho, não permitindo a troca de linha entre aparelhos mediante a movimentação do chip ou sim card (como era possível no padrão GSM);

- Portfólio de aparelhos: Vivo era a única operadora com tecnologia CDMA no Brasil, portanto trabalhava com portfólio específico de aparelhos e política de vendas e precificação menos competitiva do que a concorrência (considerando a questão da escala);

- Processo mais complexo para realização de roaming internacional (uso do celular em outros países): como o padrão de tecnologia da maioria dos países estrangeiros era o GSM, o cliente Vivo que desejasse utilizar sua linha celular nestes países precisava solicitar um "kit" à operadora em que outro aparelho, adequado a estas condições, era disponibilizado ao cliente durante o período da viagem.

Conforme identificado no tópico de composição do contexto, em 2006, a Vivo, motivada por fatores relacionados à estratégia futura do negócio, à estratégia mercadológica corrente e experiência do cliente com o serviço, a Vivo decide pela mudança do padrão tecnológico de sua operação. Cabe destacar que, no Brasil, a operadora Vivo foi a única operadora de comunicação móvel a realizar este movimento estratégico, de troca de toda a base tecnológica de atuação, de CDMA para GSM.

Em paralelo, durante os anos de 2006 e 2007, a empresa passou por um ciclo de encerramento da consolidação de sistemas (sistemas de faturamento, atendimento e gestão de informações dos clientes), o que permitiu também dispor de um novo conjunto de soluções eficazes e um modelo de operação mais simplificado e ao mesmo tempo mais robusto. Isso contribuiu bastante para os altos índices de disponibilidade e desempenho que, segundo os entrevistados, foram atingidos ao longo do ano.

De forma prática, para a realização de um processo dessa magnitude, foi criado um comitê de projeto interno, denominado "Projeto W", com diversas frentes de trabalho, de forma a coordenar e garantir a implementação da nova rede GSM nos prazos determinados, que previa conclusão em prazo recorde para os padrões nacionais e internacionais. Foram diversas frentes de trabalho dedicadas à elaboração de especificações, desenvolvimentos, testes e 
implantações em produção. O esquema da ilustração 37, oriundo de material coletado nas entrevistas, apresenta a estrutura formal do comitê reunido para o "Projeto W".

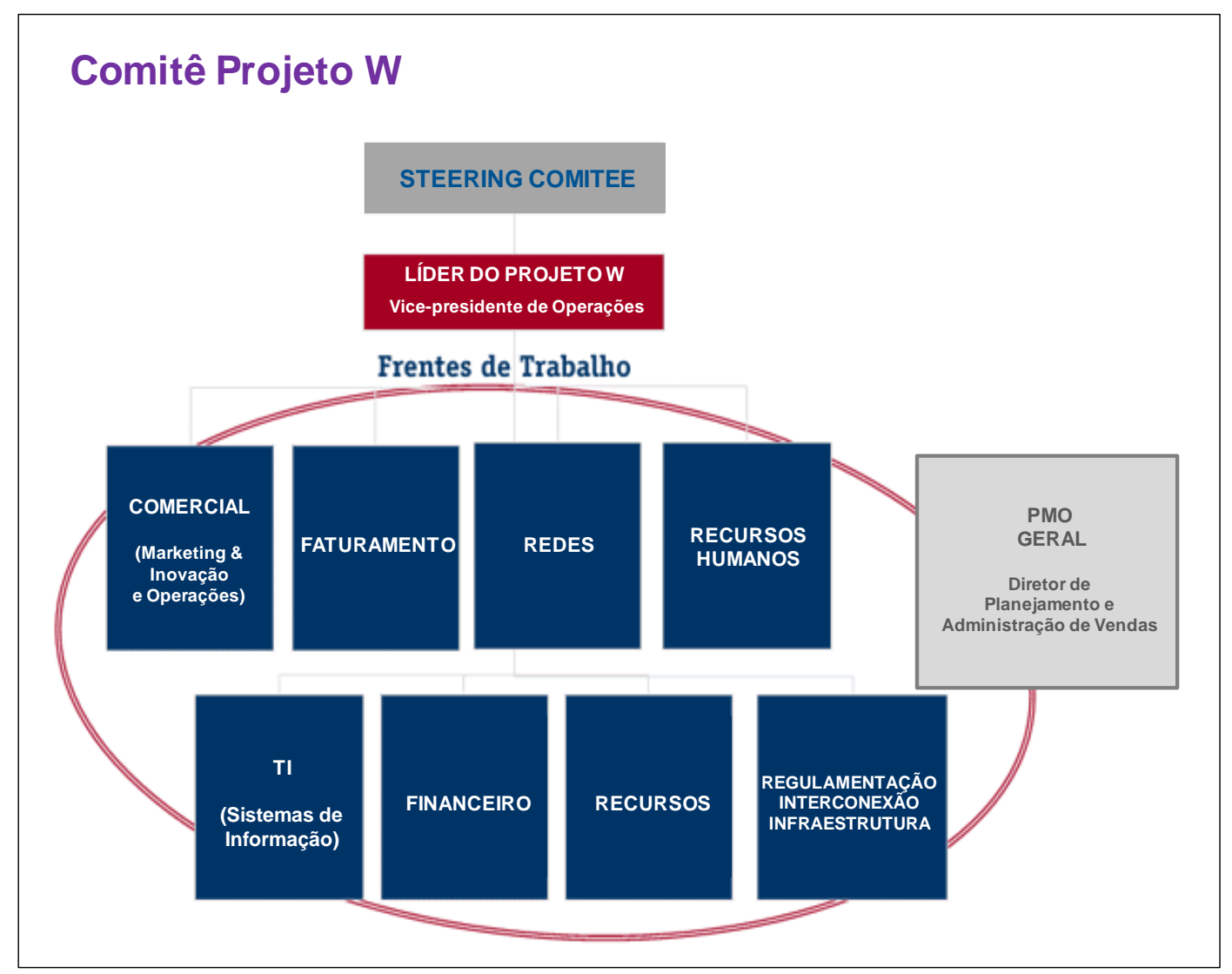

Ilustração 37 - Estrutura do comitê do Projeto W

Fonte: Material interno da empresa

Como o modelo de organograma descreve, as principais áreas da empresa foram reunidas em um comitê, liderado pelo vice-presidente de Operações, organizados em frentes de trabalho, sob acompanhamento de um PMO (Project Management Office), sob responsabilidade da Diretoria de Planejamento e Administração de Vendas.

As atividades desenvolvidas por este comitê tiveram início com a assinatura de um contrato de infraestrutura de tecnologia GSM com as empresas Huawei / Ericsson em agosto de 2006 e, apenas quatro meses após, a primeira venda comercial na tecnologia GSM já era realizada em São Paulo. Segundo os entrevistados, o projeto foi desenvolvido em prazo recorde, apesar de sua complexidade. Como parâmetro, as empresas concorrentes levaram em média três anos para a realização de projetos semelhantes, o que ilustra o caráter de desafio e ambição do projeto. 
Também se pôde perceber a ambição dos executivos não apenas pela questão do prazo, mas também no tocante à qualidade da implantação e serviços a oferecer. Além dos testes feitos pelas áreas técnicas, foi implementada a prática de um Business Simulation. Com isso, a empresa testou, com a ótica dos clientes, os principais processos críticos que iriam sofrer alteração em relação ao CDMA, além de verificar o treinamento da força de vendas e desempenho dos principais serviços oferecidos. Segundo a empresa, mais de 1.000 colaboradores participaram do teste e contribuíram para que fossem antecipados inúmeros problemas que poderiam ocorrer junto aos clientes.

Conforme documento interno da empresa, alguns grandes números dão ideia da magnitude do "Projeto W": foram cerca de 1 bilhão de reais investidos, mais de duas mil pessoas estiveram diretamente envolvidas no projeto e mais de 29 mil pessoas foram treinadas, atingindo mais de 300 mil horas de treinamento.

Por fim, ainda cabe destacar a complexidade incremental observada de se manter a qualidade da operação CDMA sem impacto aos clientes à época, em paralelo à integração da nova rede GSM.

Neste ponto, observa-se que a estratégia adotada de imediato pela operadora considerava a convivência das tecnologias CDMA e GSM. No discurso da presidência, pôde-se perceber esta intenção. Na ilustração 38 apresenta-se parte deste discurso, resgatado de materiais de comunicação interna da empresa. As versões completas estão expostas ao final, no ANEXO 1.

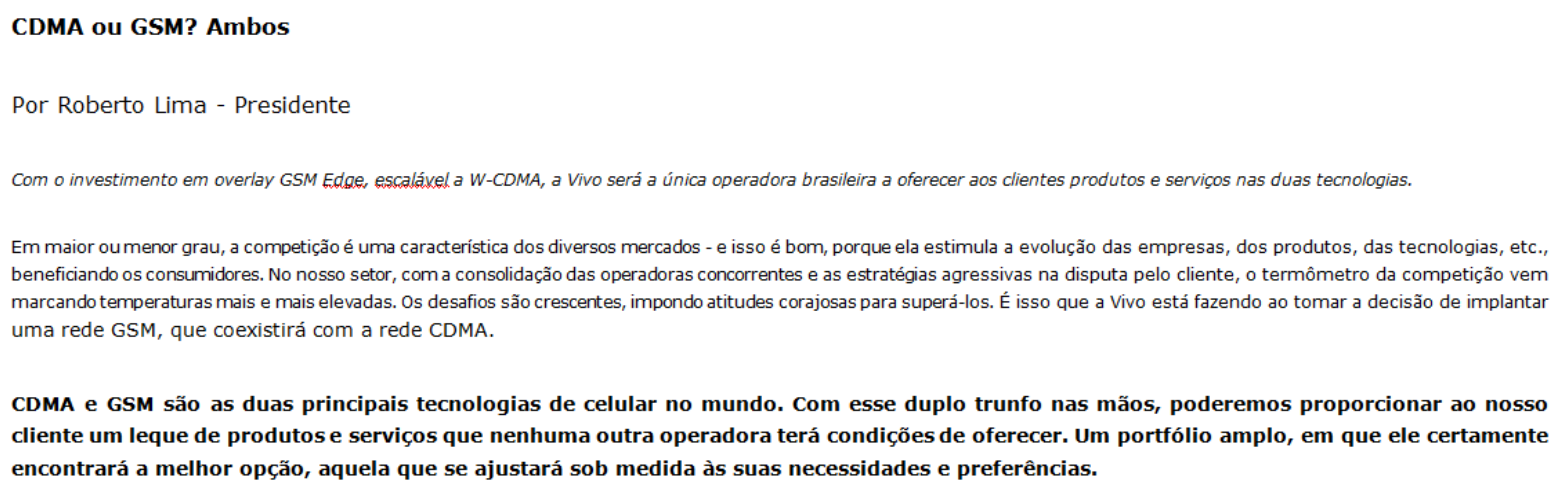

CDMA e GSM são as duas principais tecnologias de celular no mundo. Com esse duplo trunfo nas mãos, poderemos proporcionar ao nosso cliente um leque de produtos e serviços que nenhuma outra operadora terá condições de oferecer. Um portfólio amplo, em que ele certamente encontrará a melhor opção, aquela que se ajustará sob medida às suas necessidades e preferências.

\section{Ilustração 38 - Discurso interno da presidência - CDMA ou GSM? Ambos}

Fonte: Material interno da empresa, disponível na intranet

Como destacado, a estratégia considerou, de certa forma, segmentar a atuação comercial da operadora de acordo com as necessidades do cliente. Assim, com a manutenção da rede e das ofertas comerciais em CDMA e a introdução da rede e ofertas comerciais em GSM, a Vivo se 
colocou como uma proposta mais completa e ampla, tendo sempre a melhor opção, adequada às necessidades e preferência dos distintos clientes.

\subsubsection{Mudança de estratégia: foco na prestação de serviços}

A "mudança de estratégia", conforme já anteriormente mencionado, representa mais uma mudança de postura empresarial, resultante direta da mudança de comando no período de estudo do evento-foco.

Segundo os entrevistados, a vinda do novo presidente, Roberto Lima, com vasta experiência anterior em empresas do ramo de serviços, entre outras, nos segmentos de hotelaria e cartão de crédito do Brasil, trouxe uma visão sólida e consolidada de prestação de serviços.

Os entrevistados reforçaram as mudanças significativas nos processos internos e, sobretudo, no modo de pensar e agir trazido pela nova gestão. Foi possível perceber certa transição entre uma empresa baseada numa visão de engenharia (foco na tecnologia) para uma empresa baseada numa visão de serviço (foco na prestação de qualidade).

O discurso da presidência à época denota essa preocupação com a qualidade e a orientação da empresa em torno dessa entrega. Mais uma vez se destaca um trecho adaptado de material de comunicação interna da empresa, cujo material original se encontra na íntegra no ANEXO 1 deste trabalho.

\begin{tabular}{|c|c|c|}
\hline$\underset{n}{\frac{1}{n}}$ & $\begin{array}{l}\text { EV Frente aos desafios de 2007, o que } \\
\text { a Vivo espera dos colaboradores? } \\
\text { RL Que todos se concentrem nos três pontos } \\
\text { básicos: na qualidade de prestação de ser viço, } \\
\text { mesmo num ambiente de adoção de uma nova } \\
\text { rede, com uma nova tecnologia; na qualidade de } \\
\text { faturamento e recarga, de forma que o cliente } \\
\text { tenha cer teza de estar pagando o preço justo } \\
\text { por aquilo que está recebendo de serviço; na } \\
\text { qualidade do atendimento, sur preendendo } \\
\text { positivamente o cliente nos seus contatos com } \\
\text { lojas e call center. Ao mesmo tempo, temos de } \\
\text { buscar aumento de receitas num mercado que } \\
\text { trabal ha com perspectivas de preços mais baixos. }\end{array}$ & $\begin{array}{l}\text { E temos de trabalhar na recuperação dos clientes } \\
\text { de alto valor que, eventualmente, possamos } \\
\text { ter perdido. Enfim, temos grandes desafios } \\
\text { para } 2007 \text { e boas razões para encará-los com } \\
\text { otimismo. Para isso, contamos com uma empresa } \\
\text { muito mais bem-estruturada e contamos, } \\
\text { sobretudo, com a competência e a garra do nosso } \\
\text { time de colaboradores. Não é porque temos todas } \\
\text { as condições reunidas que voltaremos a crescer } \\
\text { mais que o mercado. Isso vai acontecer colocando } \\
\text { esse objetivo como nossa prioridade número } 1 . \\
\text { Agora, depende de cada um de nós arregaçar } \\
\text { as mangas e explorar esses novos trunfos da } \\
\text { Vivo para engatar a marcha do crescimento e da } \\
\text { rentabilidade. }\end{array}$ \\
\hline
\end{tabular}

Ilustração 39 - Discurso interno da presidência - Desafios para 2007

Fonte: Material interno da empresa 
A "nova" estratégia, derivada desta visão de prestação de serviços, abrangia três pilares principais de atuação, frente ao contexto competitivo em que a empresa estava inserida. Em primeiro lugar, destacava-se a importância do "falar", sendo que a operadora deveria ser capaz de ampliar cada vez mais sua cobertura, nacional e internacionalmente, e garantir a qualidade superior do sinal nas ligações e transmissões de dados. O segundo ponto representava a capacidade em "atender", prestando um atendimento resolutivo e ágil nas lojas e no call center para qualquer necessidade, dúvida ou problema que os clientes viessem a enfrentar. O terceiro e último estava relacionado ao "pagar", ou seja, a empresa se preocupava com uma forma de cobrança justa, com ofertas competitivas e com um método eficaz, sem erros ou problemas de faturamento.

Esta estratégia internamente se denominou "tripé da qualidade" e representam pontos básicos da atuação de uma empresa de serviços e eram cruciais e decisivos para a atuação da empresa à época do evento-foco.

Além disso, nesse mesmo movimento, passou a haver maior valorização da base de clientes, com ações, ofertas e comunicação desenvolvidas de forma exclusiva, na contramão das práticas correntes do mercado, que privilegiavam a aquisição de novos clientes ou de clientes da concorrência. Questões como relacionamento entre a empresa e o cliente também ganharam importância, reforçando a preocupação com a prestação do serviço e a valorização do cliente ao longo do seu ciclo de vida para com a empresa.

Do ponto de vista do planejamento estratégico, tal mudança de postura e a implementação de fato dessa nova visão de prestação de serviços foi operacionalizada através de um programa de projetos, indicadores e metas denominado "Projeto Impulso". Este projeto traduziu, através da ferramenta de avaliação de desempenho BSC (Balanced Scorecard), as grandes metas referentes ao "tripé da qualidade" ao longo da atuação de todas as áreas da empresa, incluindo as desafiadoras metas de implantação da nova rede GSM.

A ilustração 40 exemplifica as 11 frentes de trabalho definidas, agrupando 36 projetos a serem desenvolvidos durante o ano de 2007. Vale destacar as frentes 1, 2 e 3, que enfocam a atuação junto aos segmentos definidos pela empresa em sua base de clientes: segmento Empresas, formado por Grandes Contas Nacionais e Pequenas e Médias Empresas; segmento Premium, em sua maioria formado por clientes pós-pagos e segmento Massivo, em sua maioria formado por clientes pré-pagos. E também as frentes 4, 5 e 7, que enfocam as questões referentes à qualidade de atendimento, de cobrança e de rede (CDMA e GSM). 


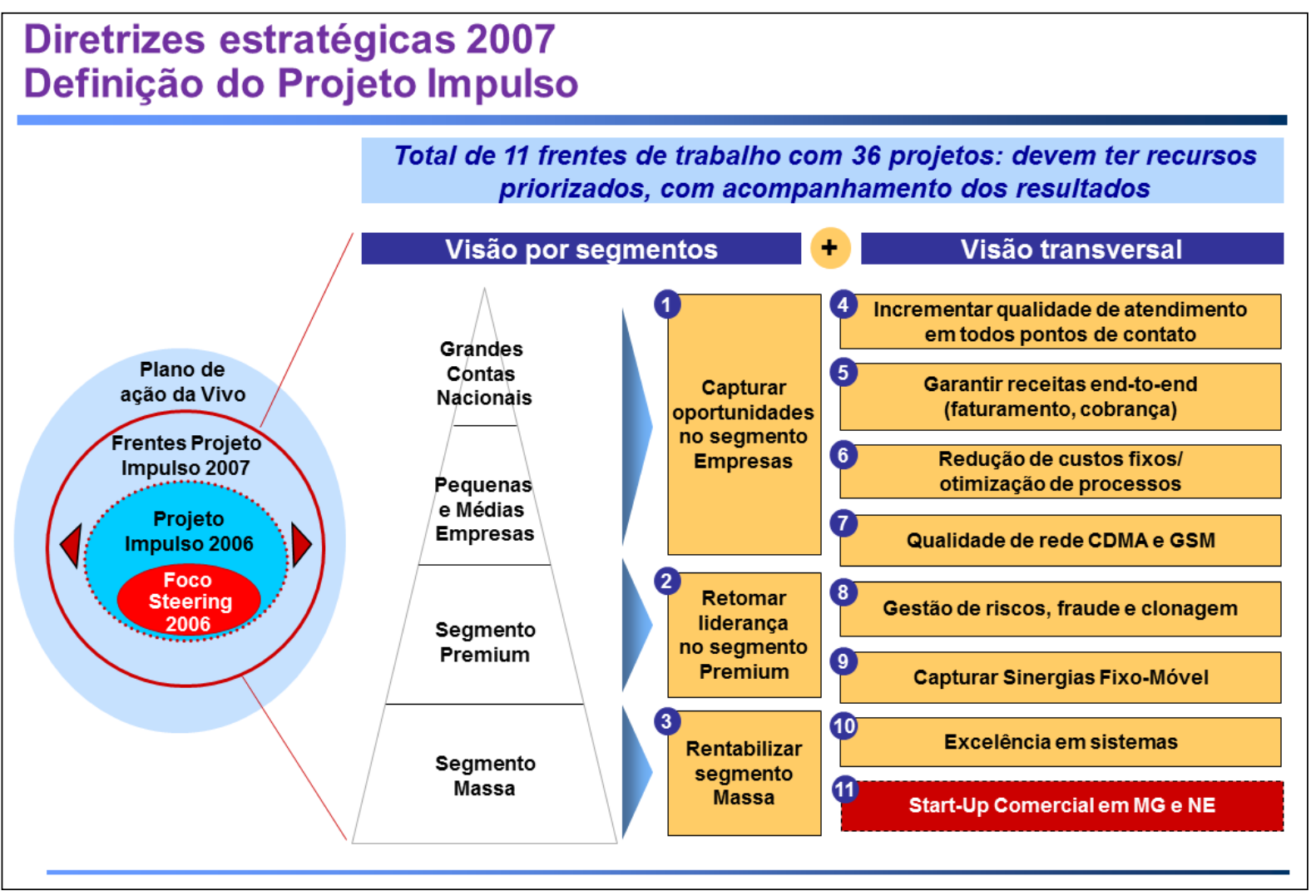

Ilustração 40 - Diretrizes estratégicas 2007 - Projeto Impulso

Fonte: Material interno da empresa

\subsubsection{Mudança de posicionamento: Vivo. Sinal de qualidade}

Em paralelo à reordenação estratégica em curso na empresa durante este período, também se buscou rever a estratégia de posicionamento da marca. Frente às diversas alterações no ambiente à época do evento-foco, tanto internas, nomeadamente mudanças de tecnologia, de comando e de estratégia no nível mais macro, como externas, considerando a situação e as movimentações das principais concorrentes do mercado, os entrevistados enfatizaram o fato da própria empresa se questionar sobre a necessidade de um novo posicionamento, uma nova forma de ser vista pelos seus clientes e potenciais consumidores.

A ilustração 41 exemplifica as inquietações e preocupações dos executivos à época das mudanças. Entre as principais motivações estavam: a busca por maior relevância para o cliente; a revisão do posicionamento vigente, fortemente baseado em dimensão; a introdução da tecnologia GSM; e as mudanças concomitantes de posicionamento das marcas concorrentes do mercado de telecomunicação móvel. 


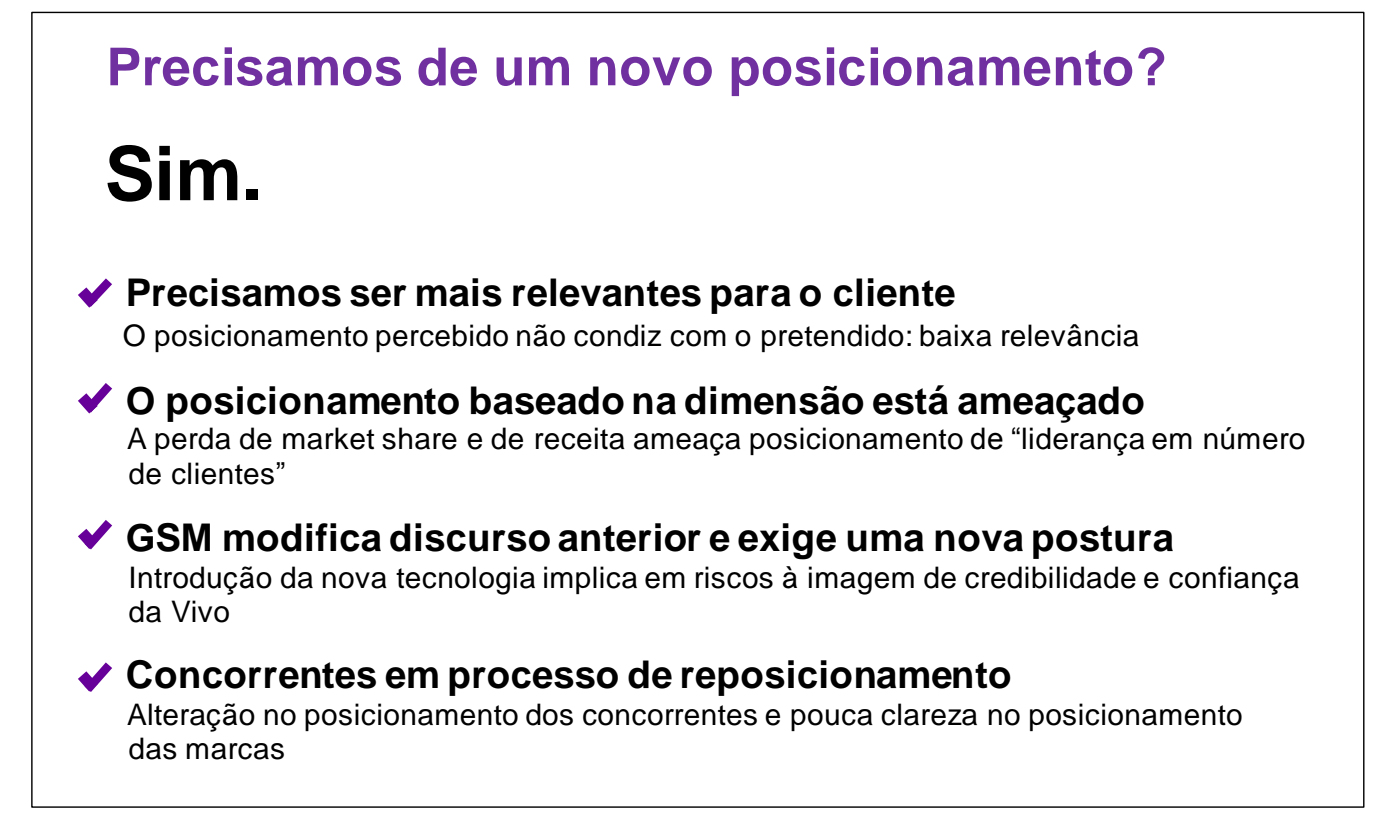

\section{Ilustração 41 - Motivações para um novo posicionamento Vivo Fonte: Material interno da empresa}

$\mathrm{Na}$ busca de uma nova proposta de posicionamento de marca, segundo os entrevistados, a empresa fez uso extensivo de informações derivadas de pesquisas de mercado, benchmarks de operadoras estrangeiras, além de contar com o potencial de planejamento e criação das agências de propaganda.

A análise do posicionamento de marca vigente à época "Vivo. É você em primeiro lugar", direcionador de toda a comunicação e forma de relacionamento da empresa com os clientes, mostrou que a proposta já não mais atendia para a dinâmica de mercado daquele momento. A ilustração 42 representa esta análise, sob a ótica da empresa.

Posicionamento Vivo em 2006

\section{vivo é você em primeiro lugar.}

- Concebida para o lançamento da marca, foi utilizada até $3^{\circ}$ trimestre/2006;

- Traduz o posicionamento baseado na dimensão / liderança: empresa e clientes em primeiro lugar;

- Hoje mostra-se pouco adequada: percepção de entrega não acompanha a promessa.

Ilustração 42 - Avaliação da assinatura de posicionamento vigente em 2006 Fonte: Material interno da empresa 
O passo seguinte, segundo os entrevistados, foi a realização da análise do cenário de posicionamento das principais marcas do mercado de telecomunicação móvel. Utilizou-se uma pesquisa robusta contratada pela empresa junto ao instituto de pesquisa espanhol PRM, realizada em todo o Brasil entre os meses de abril e julho de 2006, com 17.280 entrevistas pessoais, com usuários e não-usuários, incluindo clientes de todas as operadoras.

\section{Gráfico 11 - Cenário de posicionamento das marcas}

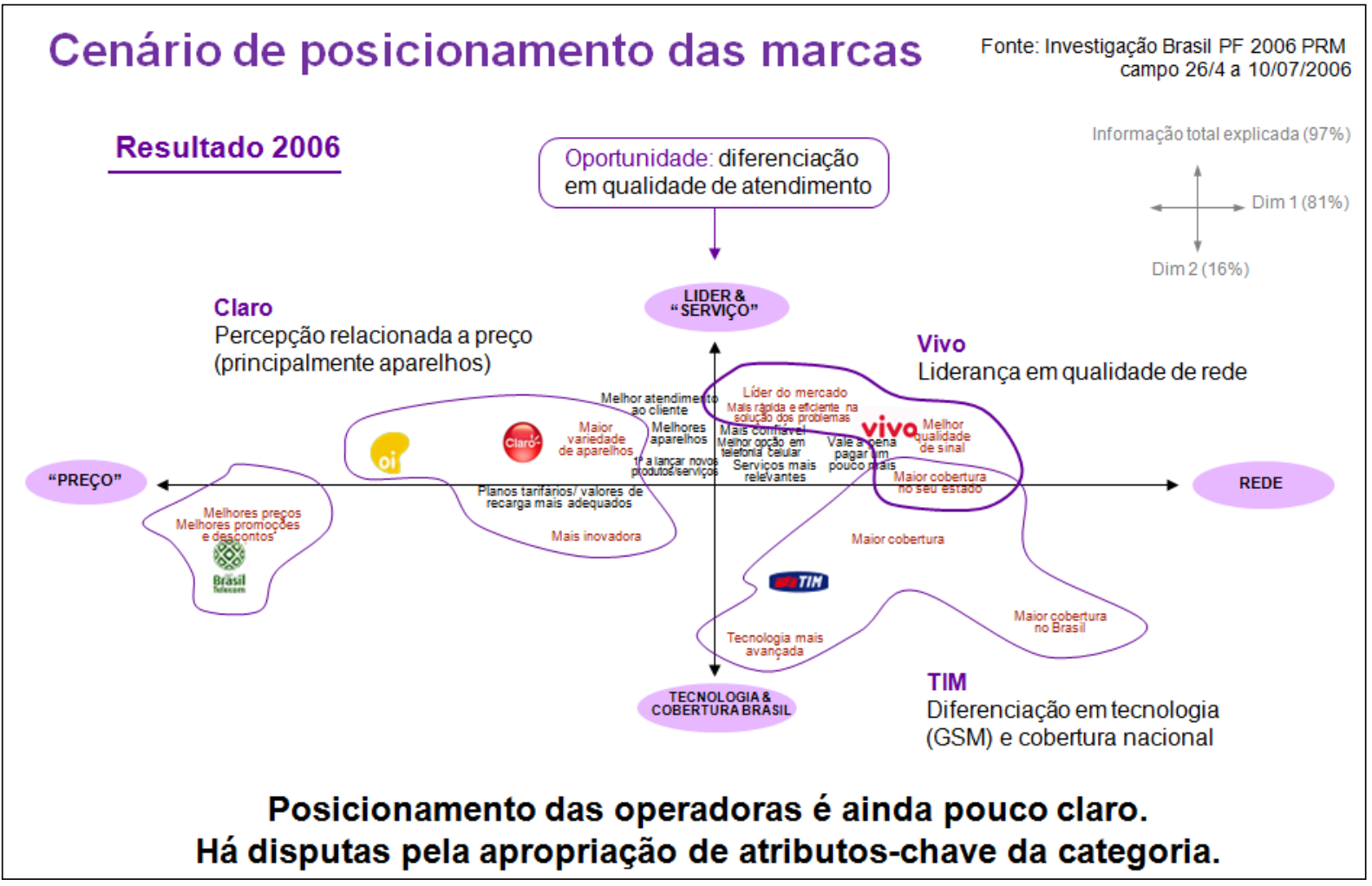

Fonte: Investigação Brasil 2006 PRM, disponibilizado pela empresa

O gráfico 11 apresenta os resultados de uma análise fatorial em que se definem como e quais dimensões de atributos estavam mais associadas a cada uma das marcas de telefonia móvel à época. A análise permite identificar quatro dimensões principais que mais diferenciam o posicionamento das marcas: no eixo horizontal, que explica $81 \%$ das diferenças, se opõem as dimensões "preço" e "rede" (neste último estão agrupadas questões como cobertura e qualidade de sinal); e no eixo vertical, que explica $16 \%$ das diferenças, se opõem as dimensões "líder e serviço" e "tecnologia \& cobertura Brasil".

De forma geral, a conclusão à época era a de que a marca TIM havia construído para si uma diferenciação baseada numa comunicação consistente dos atributos de tecnologia GSM e 
cobertura nacional. E Claro, apesar dos esforços da marca até aquele momento (e de também ter o GSM), estava mais percebida no quadrante referente a preços, principalmente de aparelhos, junto a marcas como Oi e Brasil Telecom. A avaliação da empresa ainda dava conta de que Vivo liderava em qualidade de rede e tinha força em liderança de mercado, mas de forma geral, considerava-se que as operadoras ainda tinham posicionamento pouco claros, já que a proximidade às dimensões não eram muito fortes nem exclusivas, havendo ainda muita disputa entre as marcas em diversos atributos. De forma conclusiva, considerava-se como oportunidade a buscar uma diferenciação em direção aos atributos relacionados à qualidade de atendimento, do qual nenhuma marca ainda havia se aproximado.

Além de se avaliar o posicionamento das marcas em relação às dimensões de atributos, a empresa buscou então entender os atributos de imagem aos quais as marcas estavam mais associadas.

O gráfico 12, no formato de "radar" indica a opinião dos clientes. Em primeiro lugar, cabe destacar a ordem de importância dos atributos para escolha e permanência junto a uma empresa de telecomunicação móvel. A leitura dessa informação deve ser feita no sentido horário, a partir do primeiro atributo, ou seja, o atributo considerado como o mais importante à época era "melhores preços" e o de menor importância era "vale a pena pagar um pouco mais para ser cliente dela". Em segundo lugar, observam-se, para cada uma das três principais marcas (Vivo, TIM e Claro) como os atributos estavam associados a cada uma delas à época.

Entre as principais constatações da empresa estava, em relação às versões de anos anteriores do mesmo estudo, o fato de que a importância de atributos mais básicos havia aumentado. Dos dezenove atributos avaliados, os cinco atributos considerados mais importantes pelos clientes referiam-se à entrega básica: preço, qualidade de sinal, promoções e descontos, atendimento ao cliente e planos e valores de recarga adequados.

De forma geral, a empresa avaliou ainda que a vantagem de Vivo diminuía em relação ao principal concorrente à época, a marca TIM, mas que a vantagem de Vivo em relação a todas as marcas era fortemente significativa no atributo "qualidade de sinal", considerado o segundo mais importante e que apresentava também uma vantagem razoável no atributo de atendimento ao cliente, o quarto atributo mais importante.

Vale mencionar que estas conclusões foram, segundo os entrevistados, cruciais para a forma como o novo posicionamento foi então construído pela empresa. 
Gráfico 12 - Cenário de associação aos atributos de imagem de marca

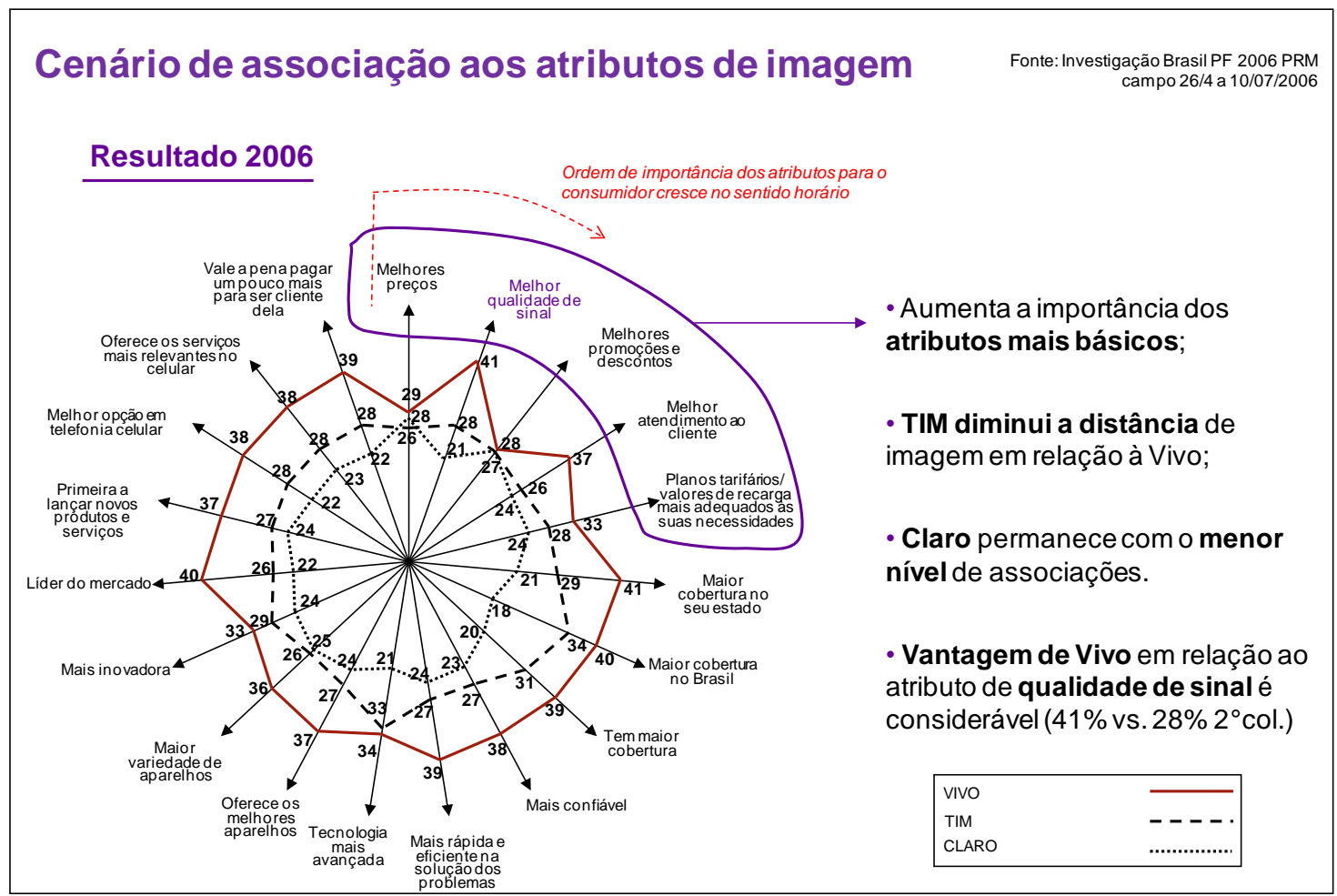

Fonte: Investigação Brasil 2006 PRM, disponibilizado pela empresa

Segundo os entrevistados, para a definição do novo posicionamento, foi realizado um raciocínio integrado entre segmentação e posicionamento, sumarizado na ilustração 43 , que considerou os aprendizados obtidos a partir da análise da posição da marca Vivo e das concorrentes, bem como dos atributos mais valorizados pelo cliente.

\begin{tabular}{|ll|}
\hline Posicionamento proposto & \\
\hline $\begin{array}{l}\text { Sericionamento atual } \\
\text { (proposta atual) }\end{array}$ &
\end{tabular}

Ilustração 43 - Posicionamento Vivo vigente x pretendido

Fonte: Material interno da empresa 
Assim, a ilustração 43 apresenta a forma como a empresa buscou definir um novo posicionamento pretendido, ao definir para cada segmento, em que atributo buscaria se diferenciar (preço, relacionamento e inovação), além de se diferenciar em um, mas apenas um atributo igualmente importante para todos os segmentos (qualidade de ligação).

O quadro 19 resume de forma assertiva os pilares do novo posicionamento pretendido pela empresa, de forma a trazer mais relevância e diferenciação para a marca, por meio do desenvolvimento de atributos específicos para determinados segmentos. Além disso, segundo os entrevistados, neste mesmo quadro, realizou-se a associação dos pilares do novo posicionamento às diretrizes estratégicas do já mencionado "tripé da qualidade" (melhor ligação = "falar"; relacionamento = "atender"; preço = "pagar").

\section{Quadro 19 - Pilares do novo posicionamento proposto}

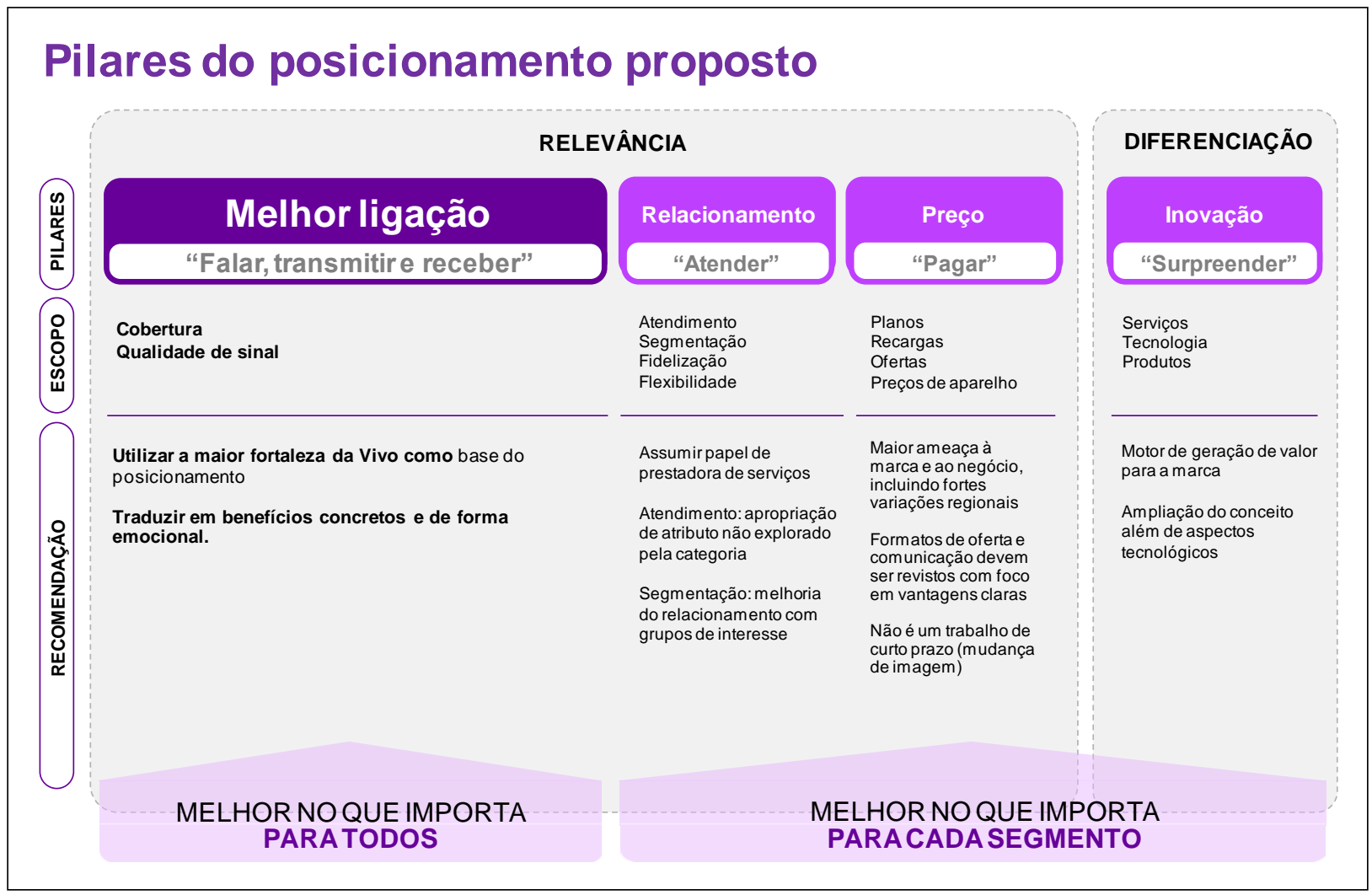

Fonte: Material interno da empresa

E, no que se refere ao posicionamento psicológico, representado através das diversas ações de comunicação e relacionamento da empresa, novas diretrizes foram desenvolvidas para evolução do posicionamento vigente. Os quadros 20 a 24 apresentam e detalham um conjunto de quatro diretrizes que, segundo os entrevistados, foram desenhadas para o novo posicionamento pretendido, de forma a contribuir para gerar maior diferenciação e relevância. 
Quadro 20 - Quatro diretrizes para o novo posicionamento

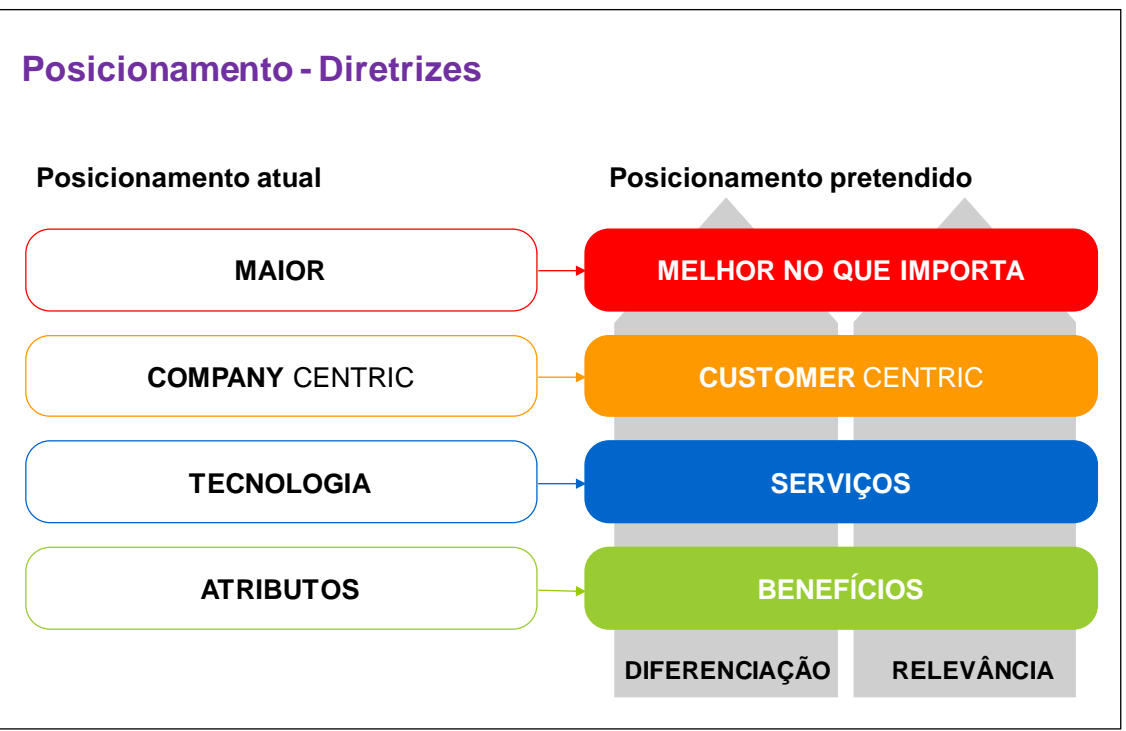

Fonte: Material interno da empresa

Quadro 21 - Quatro diretrizes para o novo posicionamento

\begin{tabular}{|ll|}
\hline \multicolumn{1}{|c|}{ Posicionamento atual } \\
\hline \multicolumn{1}{|c|}{ MAIOR } \\
- Quantitativo & - Resicionamento pretendidativo \\
- Liderança em tamanho & - Reconhecer o indivíduo \\
- Maionsão da operadora & - Soluções diferentes para cada segmento \\
- Maior cobertura do de clientes & Melhor no que importa para cada um \\
- Maior operadora do País. & \\
\hline
\end{tabular}

Fonte: Material interno da empresa

\section{Quadro 22 - Diretriz "customer centric"}

\begin{tabular}{|l|}
\hline \multicolumn{1}{|c|}{ Posicionamento atual } \\
COMPANY CENTRIC
\end{tabular}

Fonte: Material interno da empresa 
Quadro 23 - Diretriz "serviços"

\begin{tabular}{|l|}
\hline \multicolumn{1}{|c|}{ Posicionamento atual } \\
\hline \multicolumn{1}{|c|}{ TECNOLOGIA }
\end{tabular}

Fonte: Material interno da empresa

Quadro 24 - Diretriz "benefícios"

\begin{tabular}{|ll|}
\hline \multicolumn{1}{|c|}{ Posicionamento atual } & \multicolumn{1}{|c|}{ Posicionamento pretendido } \\
&
\end{tabular}

Fonte: Material interno da empresa

Ao se tomar em conjunto a evolução do conjunto dessas quatro diretrizes, os entrevistados reforçaram este momento como único, a partir do qual a operadora iniciou uma nova fase em que o cliente estivesse sempre no centro do discurso, e que este fosse sempre direto e transparente, focado nas necessidades do cliente. Tais diretrizes alteraram de certa forma os conceitos anteriores da marca, que eram mais direcionados na comunicação dos atributos da empresa e em seus diferenciais tecnológicos e de inovação.

Segundo os entrevistados, para manter e evoluir essa nova etapa da marca, era preciso utilizar um fio condutor forte o suficiente para movimentar todo esse novo direcionamento, criando experiências e vínculos com os clientes e consumidores em potencial, representando fielmente as intenções da Vivo. A ilustração 44 esquematiza finalmente o racional que levou à definição da nova assinatura da marca, "Vivo. Sinal de qualidade", representativa do novo posicionamento pretendido. 
Racional para novo posicionamento

Vivo: a melhor qualidade de sinal.

Qualidade de serviços

vivo Sinal de qualidade.

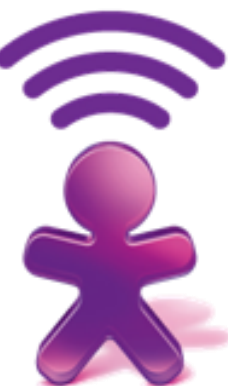

QUALIDADE deve ser o fio condutor da comunicação e da operação da empresa

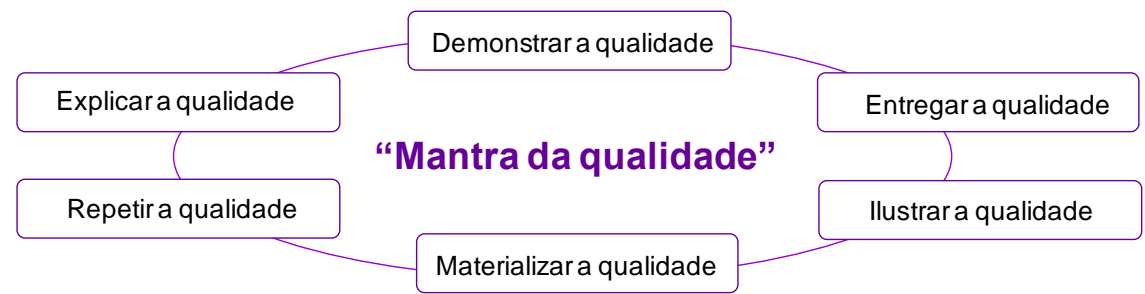

Tangibilizar o conceito - através de um novo posicionamento que apresente qualidade em todos os momentos e formas de contato (touchpoints):

$\begin{array}{lll}\text { - Comunicação } & \text { • Fatura } & \text { - Produtos e Serviços } \\ \text { - Aparelhos } & \text { - Canais eletrônicos } & \text { - Marketing direto } \\ \text { - Lojas } & \text { - Atendimento } & \text { - Máquina e cartão de } \\ \text { - Embalagens } & \text { - Endomarketing } & \text { recarga }\end{array}$

Ilustração 44 - Racional para novo posicionamento "Vivo. Sinal de qualidade" Fonte: Material interno da empresa

De acordo com os entrevistados, o potencial, reconhecimento e associação da marca ao atributo "qualidade de sinal" foram considerados para representar o compromisso e o diferencial da marca Vivo. E deveria ainda, a partir de uma ideia criativa simples e poderosa, traduzir a intenção da empresa em se tornar um "sinal de qualidade" em todos os seus pontos de atuação, sobretudo nas questões referentes ao "tripé da qualidade". 


\subsection{Impactos no composto de marketing de serviços}

O conjunto das mudanças observadas, de tecnologia, de estratégia e de posicionamento, refletiram-se diretamente sobre os diversos fatores que compõem o mix de marketing de serviços. Através das entrevistas com executivos das diversas áreas da empresa, pôde-se observar como, em diferentes níveis, cada fator do mix de marketing foi impactado e como a empresa os gerenciou, de forma a buscar alcançar as metas estratégicas do "Projeto Impulso", na linha de visão do comando, garantindo o "tripé da qualidade", e contribuindo para construir o posicionamento "Sinal de qualidade". A mudança de tecnologia, do CDMA para o GSM, e mais que isso, a convivência das tecnologias trouxe oportunidades de mercado e desafios de operacionalização em diversos momentos da gestão do composto de marketing.

A partir das entrevistas realizadas e de todos os materiais e dados secundários coletados e analisados, criou-se uma matriz apresentada no quadro 25, com uma avaliação dos níveis de impacto e mudança observados em cada um dos fatores do composto de marketing da empresa, para todo o ano de 2007 (antes, durante e após as mudanças de tecnologia e de posicionamento).

Quadro 25 - Níveis de impacto no composto de marketing Vivo

\begin{tabular}{|l|l|c|l|}
\hline $\begin{array}{l}\text { Fator do mix de } \\
\text { marketing de serviços }\end{array}$ & $\begin{array}{l}\text { Fator(es) correspondente(s) } \\
\text { na gestão da empresa }\end{array}$ & \multicolumn{2}{|l|}{$\begin{array}{l}\text { Nível de impacto ocasionado } \\
\text { pelas mudanças de tecnologia e posicionamento }\end{array}$} \\
\hline "Produto" & Serviços e aparelhos & alto & Lançamentos em geral \\
\hline "Preço" & Planos, recargas e promoções & médio & Ajustes de ofertas \\
\hline "Promoção" & Comunicação e vendas & alto & Novo discurso / novas diretrizes \\
\hline "Praça" & Distribuição e logística & baixo & Pequenas adaptações nas atividades \\
\hline "Physical surroundings" & Instalações e lojas & baixo & Pequenas adaptações nos pontos-de-contato \\
\hline "Processos" & Atendimento e sistemas & médio & Readaptações no modus operandi existente \\
\hline "Pessoas" & Colaboradores e atendentes em geral & alto & Forte mudança de postura \\
\hline
\end{tabular}

Fonte: Criado pelo autor

Nos tópicos a seguir serão analisados em detalhe os principais desdobramentos em cada um dos "P"s do mix de marketing Vivo no período, a fim de se entender o impacto das mudanças em cada um destes. 


\subsection{1 "Produto": serviços e aparelhos}

Antes de se iniciar de fato uma revisão das principais ações desenvolvidas pela operadora no que se refere ao "P" de produto, de forma a refletir as mudanças de tecnologia e posicionamento, vale esclarecer exatamente o que compõe essa categoria do composto de marketing em uma empresa de serviços de telecomunicações.

Ao considerarmos serviço uma proposta de produto ampliado, em telecomunicações, inicialmente deve-se considerar a parte estrutural da entrega como a parte mais básica do serviço, ou seja, o core da prestação, que é a conexão ("falar", "navegar"). Neste ponto a mudança de tecnologia foi crucial, permitindo à operadora passar a oferecer aos clientes atuais e novos, a possibilidade de se comunicar através da tecnologia GSM, já conhecida por meio da atuação das concorrentes. O grande desafio foi a manutenção da mesma qualidade de rede e a expansão da cobertura a um número de municípios tão grande como já existia no CDMA e que concedia vantagem e credibilidade à empresa.

Num estrato intermediário está a comercialização de aparelhos (celulares, placas, modens), que embora não seja de fato produzido pela operadora, é incluído no conjunto da proposta comercial e muitas vezes se torna um importante diferencial para o cliente, especialmente quando se consegue trabalhar com exclusividade junto ao fabricante. Nesse ponto, a mudança de tecnologia permitiu enfim à Vivo poder oferecer aos clientes o portfólio mais completo, com já ofertados aparelhos CDMA e os novos aparelhos, com a tecnologia GSM. Isso também significou a possibilidade de uso de diversos aparelhos GSM por um mesmo cliente, sendo necessário apenas trocar o chip (sim card) entre os aparelhos.

E, numa visão mais ampliada, o a relação do serviço entre operadora e cliente é representada por meio da contratação de um plano, pós-pago ou pré-pago, através do qual o cliente opta pelo modelo comercial mais adequado às suas necessidades e possibilidades. Neste ponto, a operadora buscou rever todo o seu portfólio, readequando planos, recargas e promoções de forma a ser mais competitiva, com propostas diferenciadas para cada segmento. De forma geral, os planos pós-pagos (de mais alto valor) foram simplificados, com o lançamento de um novo portfólio "Vivo Escolha" e as promoções para pré-pago, com bônus, ficaram mais competitivas. Além disso, com a introdução da tecnologia GSM, a oferta de serviços de valor agregado (que complementam planos de voz, como mensagens instantâneas, serviços de localização, entre outros) ficou maior e mais completa, pois se beneficiou da escala já 
existente de celulares GSM no Brasil; ou seja, o número de desenvolvedores deste tipo de serviço para aparelhos GSM já era significativamente superior.

Portanto, segundo os entrevistados, as ofertas de produtos e serviços em 2007 objetivaram um crescimento seletivo, principalmente em segmentos com maior potencial de geração de valor, buscando melhorar a percepção de preço e fortalecer a liderança de mercado. Além disso, a maior parte das campanhas de varejo de 2007 foi pautada pela segmentação, premiando os clientes de maior valor com a concessão de bônus progressivos de acordo com a minutagem dos seus planos ou valor de recarga realizado.

Para estes, foi disponibilizado um portfólio que reunia exclusividade, inovação, conteúdos diferenciados e aparelhos multimídia. Adotou-se um formato múltiplo, de modo a atender aos diversos segmentos e drivers trabalhados pela Vivo.

Durante todo o ano, as campanhas da Vivo privilegiaram os benefícios concedidos nas promoções, com a criação de ofertas que fossem atraentes e, ao mesmo tempo, favorecessem o desenvolvimento de hábitos de consumo nos clientes com incentivos e descontos.

Os principais benefícios concedidos foram bônus em ligações locais intra-rede, tarifas promocionais para ligações intra-rede (local e longa distância utilizando o código de prestadora 15 da Telefônica e redução seletiva no preço de aparelho, entre outros.

A primeira promoção do ano foi "Por Conta da Vivo", com o objetivo de divulgar a oferta de aquisição vigente para alavancar as altas no segmento premium pós-pago: concessão de bônus de até 2.500 minutos para falar com qualquer Vivo em ligações locais. No mesmo período, a campanha promocional “Até Mil Reais”, que teve como objetivo rentabilizar a base de prépago incentivou a recarga, oferecendo bônus de até $\mathrm{R} \$ 1.000$ para falar com qualquer Vivo por seis meses em ligações locais.

Para o segmento corporativo, foram desenvolvidos campanhas como a de divulgação da oferta do "Pacotes de Serviços", que destacou a produtividade e mobilidade oferecida ao cliente, permitindo a ele acessar documentos, enviar e receber e-mails ou acessar a internet de onde estiver. Outra serviço lançado foi o Vivo Flash, que possibilitava o acesso à internet móvel em mais de 1.900 cidades, através de um modem portátil sem fio conectado a um desktop. A proposta foi uma alternativa de acesso à internet em lugares não atendidos por outras tecnologias e uma solução inovadora para quem busca conveniência e praticidade. 
Vale enfatizar ainda os lançamentos de aparelhos e equipamentos - celulares, smartphones, placas e modens, disponibilizados nas tecnologias GSM ou CDMA. A safra de inovações contribuiu sobremaneira para reforçar a imagem de uma comunicação focada em soluções corporativas, por meio de inúmeros aparelhos multifuncionais.

Durante os meses de abril e maio, já após a fase de reposicionamento, no dia das mães, data com alta relevância para o varejo, a Vivo apresentou a promoção "Fale de Graça", com a disponibilização de benefícios à base de clientes e aos novos clientes. Com a expressão "os celulares que pegam bem e custam pouco", a Vivo assumiu a linha hard sell, em uma comunicação comprometida com o novo posicionamento: com desataque para a proposta de melhor qualidade aliada às melhores oportunidades e ofertas mais simples com maior impacto de custo-benefício "Fale de Graça".

A promoção "Fale de Graça" (até 2.500 minutos no Vivo Pós e até R\$ 1.000 por recarga no Vivo pré) foi planejada para alavancar a captação de novos clientes e promover a fidelização dos atuais por meio da troca com compra de novo aparelho. A partir deste benefício a concessão de bônus no pós-pago e no pré-pago adequava o volume de bônus recebido ao perfil de cada cliente. Os bônus eram válidos para utilização em ligações locais de Vivo para Vivo.

Para o Dia dos Namorados, o foco principal foi o Plano Vivo Escolha 180, com a oferta de 1.000 minutos adicionais todo mês para falar com outro Vivo ao escolher a vantagem "Favorito". Como foi mantida a oferta de pré e pós, teve continuidade a abordagem "Fale de Graça" com a "Melhor qualidade de ligação", que permeou todas as peças de comunicação e seus desdobramentos.

A volta do foco nos Planos Vivo Escolha reforçou a vantagem dos benefícios estruturais dos planos pós-pagos da Vivo e divulgou a vantagem "Favorito". Ao escolherem essa vantagem, disponível na ocasião, a partir do plano Vivo Escolha 180, os clientes ganhavam 1.000 minutos, todo mês, para falar um número Vivo de sua preferência.

Em julho, para o dia dos pais, teve início a oferta "Zero Centavo". Ela deu continuidade à promoção que vigorava, com a oferta de bônus para pós e pré, e que, em razão dos bons resultados, permaneceu durante os demais meses do ano, inclusive no período do natal.

No final de agosto, estreou a oferta "Venha para a Vivo", que teve como objetivo a captação de clientes da concorrência. Para trazer para a sua base clientes de alto valor, a Vivo apostou 
em um benefício extremamente agressivo: a gratuidade de aparelhos. De forma arrojada, foi a primeira vez que a Vivo ofereceu ao mercado e em mídia de massa celulares grátis. A operadora manteve essa oferta durante em todo o período que antecedeu o natal, ou seja, foi a aposta de varejo no período de entressafra.

Em setembro, a Vivo promoveu o benefício do Programa de Pontos, programa de fidelidade para cliente pós-pagos da Vivo, que convertia as ligações em pontos. A partir de 15.000 pontos, os clientes já podiam utilizá-los para a troca de aparelho. Dependendo do modelo escolhido, o celular novo podia até sair de graça. Mais de 2 milhões de clientes já haviam realizado trocas desde o lançamento do programa até o mês de setembro.

Em direção à convergência, a empresa lançou o "Vivo 3 em 1", impulsionada pelo Plano Vivo Escolha 90, que formava um combo com minutos locais para celular, fixo e acesso à internet. $\mathrm{O}$ cliente podia escolher entre três formas de acessar a internet do computador, do notebook ou do smartphone, com preços promocionais.

A operadora finalizou o ano com ofertas agressivas para o período do natal, concedendo bônus que permitiam a seus clientes fazer ligações locais por zero centavo, fosse para telefones fixos ou pra celulares Vivo, a qualquer hora, durante seis meses. E colocou à disposição dos clientes um portfólio com aparelhos a partir de $\mathrm{R} \$ 10$, para contratações dos planos pós Vivo Escolha 90. Novos clientes, trocas de aparelhos ou ativações de novas linhas tinham participação gratuita na oferta. Para todas as situações, era necessário o cadastramento pelo número de $* 9000$ do próprio celular.

Em síntese, 2007 foi marcado principalmente pela manutenção, durante grande parte do ano, da promoção de oferta de bônus, mediante tabela progressiva, em campanhas para os segmentos pós e pré. Segundo a empresa, isso ocorreu porque os resultados, tanto de captação quanto de recargas, foram bastante positivos nas várias datas comemorativas, como mães, namorados, pais e natal. Além disso, essa promoção teve grande capacidade de sinergia entre aquisição, fidelização e rentabilidade, reduzindo custos de comunicação e trade marketing, simplificando os desenvolvimentos de TI e melhorando a recordação dos clientes em relação à promoção. 


\subsection{2 "Preço": planos, recargas, promoções}

Para se avaliar o impacto das mudanças sobre o "P" de preço do composto de marketing, mais uma vez vale resgatar o raciocínio de como esse fator se estrutura no setor de serviços de telecomunicações.

A exemplo do que já se discutiu no tópico anterior, o fator "preço" surge em três situações da transação do cliente com uma operadora móvel: quando da contratação de um plano (de voz ou de dados), quando da compra de um aparelho (celular, placa ou modem) ou quando da contratação de serviços de valor agregado (em complemento ao plano de voz ou dados já contratado).

É também importante destacar que a opção por determinado sistema de pagamento, pós-pago (conta) ou pré-pago (recarga), também terminam por influenciar no valor das tarifas cobradas por minuto.

No caso da Vivo, por ocasião da mudança de tecnologia, houve um reajuste de preço imediato na segunda situação, por meio do lançamento de um novo portfólio de aparelhos GSM, cujo custo de oferta ao cliente se tornou significativamente mais baixo que o do portfólio de aparelhos CDMA trabalhado até então.

No caso dos "preços" referentes a planos e promoções, tanto pós-pagos como pré-pagos, uma questão que já havia sido anteriormente identificada pelos executivos, a de que o atributo "melhores preços" era considerado o mais importante, moveu a empresa para rever a sua proposta neste sentido.

Conforme observado no tópico anterior, diversos planos e promoções foram lançados durante o ano, com benefícios de minutos e bônus, de forma a manter a competitividade das ofertas da empresa, porém sem que isso representasse uma queda agressiva no preço líquido do serviço.

Portanto, considera-se que o impacto no fator preço foi mediano, sendo que a mudança tecnológica afetou diretamente os preços de aparelhos, tornando-os mais baratos. Mas para a parte estrutural do serviço, a decisão da empresa foi a de manutenção da proposta de valor "qualidade superior + preço premium", também considerando que o cenário de posicionamento das marcas já indicava três marcas ocupando a posição de "preço baixo". 


\subsection{3 "Promoção": comunicação e vendas}

Com a definição do novo posicionamento pretendido e respectivas diretrizes para atingi-lo, a empresa procedeu à definição da estratégia de comunicação que permitiria transmitir a nova postura assumida.

De acordo com os entrevistados, uma preocupação especial da empresa foi a comunicação das mudanças internamente, garantindo que todos os colaboradores tivessem consciência da nova postura da marca, mas principalmente se vissem como os componentes vitais para a verdadeira transformação do posicionamento e contribuíssem de fato para a entrega das mensagens de compromisso transmitidas.

Para transparecer o novo posicionamento, os canais de comunicação da marca deveriam transmitir os fatos relevantes como: a adoção da nova tecnologia GSM, capaz de ampliar o portfólio de produtos e aparelhos da Vivo, a erradicação de problemas como fraude e clonagem, que davam mais garantias aos clientes, a simplificação dos planos pós-pagos, a inserção de bônus para a as recargas dos clientes pré-pagos e a melhoria nos pontos de contato com o cliente (call centers, lojas).

Em relação às mudanças observadas na comunicação, pôde-se perceber o uso de celebridades como porta-vozes da marca, com o intuito de trazer credibilidade junto aos públicos e otimizar os impactos positivos e sólidos das mensagens a serem transmitidas. Além de trazer confiança e seriedade para o discurso, numa fase seguinte a empresa também apostou no apelo emocional nos enredos, que permitiriam a identificação do espectador com as situações, com os produtos e ofertas apresentados.

Segundo a empresa ainda, embora novas na comunicação da empresa, essas características se mesclariam com facilidade com os demais componentes tradicionais que representavam a marca, tais como brasilidade, jovialidade e transparência.

Do ponto de vista de identidade de marca, para pontuar esse momento de evolução da empresa, foram introduzidos, de forma sutil, novos elementos de marca, presentes em todas as de representação visual da operadora (comunicação externa e interna, lojas, instalações, entre outros). O ícone da marca, antes apresentado de forma estática, ganhou novas posições e formatos, mais orgânicos, com a intenção de aumentar a sensação de "humanidade" da marca e representar o aumento da intenção de proximidade da marca com seus clientes. Além disso, para reforçar a ideia de "sinal de qualidade", um elemento gráfico alusivo às ondas de sinal de 
rede foram incluídas junto ao ícone da marca que acompanhava a assinatura de posicionamento.

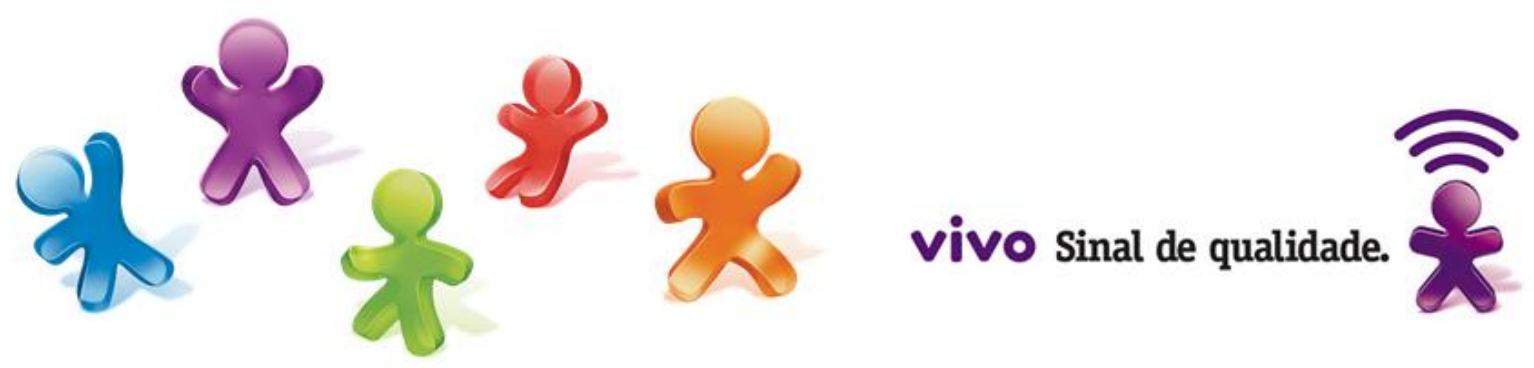

Ilustração 45 - Novos elementos de marca e nova assinatura de posicionamento

Fonte: Material interno da empresa

Para dar conta de todos os desafios, a comunicação foi realizada em mais de uma fase, com a expectativa que o cliente entendesse que se tratava de um novo momento de atuação da empresa. A comunicação integrada em todos os pontos de contato contou com campanhas publicitárias e anúncios à imprensa, iniciativas de endomarketing e ações nos pontos de venda. A ilustração 46 apresenta a estratégia de comunicação em fases, conforme campanhas veiculadas pela empresa à época.

\begin{tabular}{|c|c|c|c|}
\hline \multicolumn{4}{|c|}{ Comunicação - novo posicionamento: objetivo e estratégia } \\
\hline Objetivo & \multicolumn{3}{|c|}{$\begin{array}{l}\text { Posicionar a Vivo como uma operadora que presta um serviço } \\
\text { de qualidade em todos os pontos de contato com o cliente. }\end{array}$} \\
\hline Estratégia & $\begin{array}{l}\text { Vivo: a melhor } \\
\text { qualidade de } \\
\text { sinal. }\end{array}$ & $\begin{array}{l}\text { Qualidade } \\
\text { de serviços }\end{array}$ & vivo sinal de qualidade. \\
\hline & $\begin{array}{l}1^{3} \text { fase: } \\
\text { PRESTAÇÄO } \\
\text { DE CONTAS }\end{array}$ & $\begin{array}{l}2^{3} \text { fase: } \\
\text { LANÇAMENTO }\end{array}$ & $\begin{array}{l}\text { Continuidade: } \\
\text { DESDOBRAMENTOS }\end{array}$ \\
\hline Fases & $\begin{array}{l}\text { Ressaltar o momento de } \\
\text { mudança da operadora } \\
\text { para criar ambiente } \\
\text { propício ao lançamento } \\
\text { do novo posicionamento }\end{array}$ & $\begin{array}{l}\text { Fixar o conceito "Sinal } \\
\text { de qualidade", gerar } \\
\text { diferenciação e reforçar a } \\
\text { importância da qualidade } \\
\text { dos serviços da Vivo }\end{array}$ & $\begin{array}{l}\text { Garantir sustentação } \\
\text { e continuidade do } \\
\text { posicionamento com } \\
\text { consistência }\end{array}$ \\
\hline & & 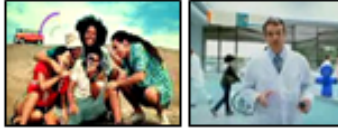 & 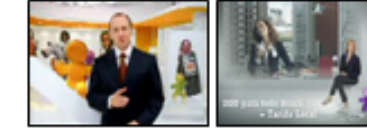 \\
\hline
\end{tabular}

Ilustração 46 - Estratégia de comunicação do novo posicionamento Fonte: Material interno da empresa 
Em linhas gerais, em uma primeira fase, no mês de março de 2007, a operadora realizou anúncios institucionais para expor os projetos que permitiram a apresentação de um novo posicionamento. Segundo os entrevistados, convencionou-se internamente em nomeá-la como uma fase de "prestação de contas". A segunda fase, ao final do mês de março de 2007, tratouse do lançamento, de fato, do "novo momento" da operadora, em que o conceito "Sinal de qualidade", representativo da nova assinatura de posicionamento da marca foi desenvolvido seguindo as diretrizes determinadas para o novo posicionamento pretendido. Na fase seguinte, de continuidade, foram comunicados as novidades nos produtos e serviços de forma mais segmentada, aos diferentes perfis de clientes (premium, massivo, corporativo).

O comercial que abriu a primeira fase foi protagonizado pela jornalista Marília Gabriela no dia 15 de março de 2007, data mundialmente comemorativa do dia do consumidor. Com este simbolismo, a operadora rompeu com os formatos tradicionais de comunicação do setor e, numa postura de transparência, relatou os principais feitos e compromissos com o mercado.

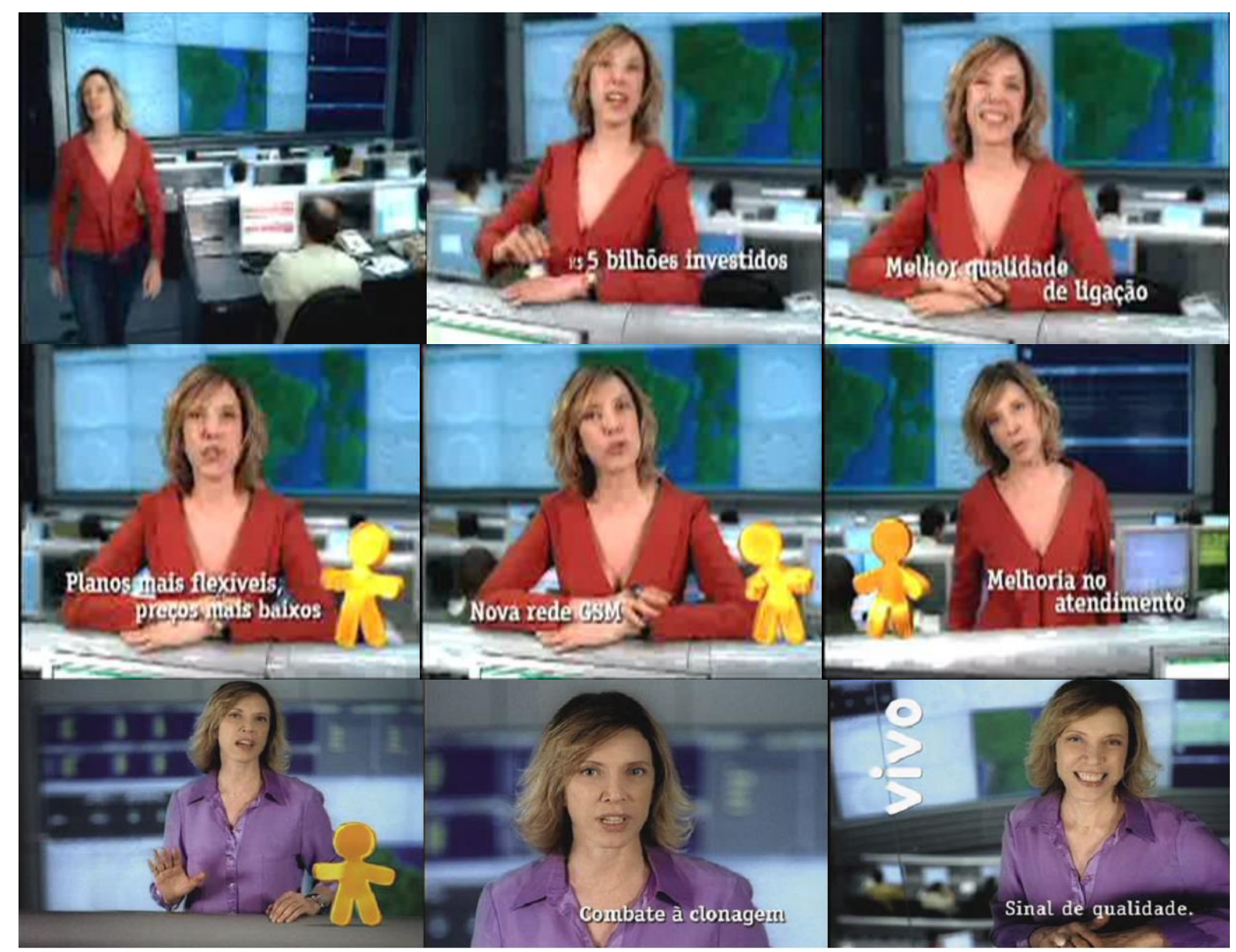

Ilustração 47 - Comercial de abertura da $1^{\text {a }}$ fase de comunicação do novo posicionamento Fonte: Material disponibilizado pela empresa, adaptado pelo autor 
Para fins de compreensão do conteúdo discurso, a seguir transcrevem-se as falas da jornalista no comercial.

\begin{abstract}
"Na semana em que se comeomora o dia do consumidor, a Vivo faz um resumo das suas realizações nesses 4 anos: a Vivo investiu $R \$ 5$ bilhões na sua rede e hoje é a operadora com a melhor qualidade de ligação. A Vivo simplificou os planos, reduziu os preços e implantou a sua rede GSM para lhe dar muito mais opção de escolha. A melhor ligação da Vivo não custa mais para você, muitas vezes é mais barata que a das demais operadoras. A Vivo investiu e continua investindo em segurança e com isso já reduziu drasticamente os casos de clonagem; por essa razão não se ouve mais falar nisso. Estamos investindo também a cada dia para que você possa ser melhor atendido. Sabemos que ainda temos muito o que fazer, mas tudo isso é sinal de mudança. É a Vivo, na semana do consumidor, dando satifação de tudo que está fazendo em respeito a você. Para ser mais do que um sinal de qualidade, para ser o seu sinal de qualidade. Vivo, sinal de qualidade."
\end{abstract}

Ainda nesta primeira fase, reforçando a ideia de compromisso e transparência, a operadora rompeu novamente com os formatos tradicionais do setor e lançou um novo comercial, desta vez protagonizado por colaboradores da empresa.

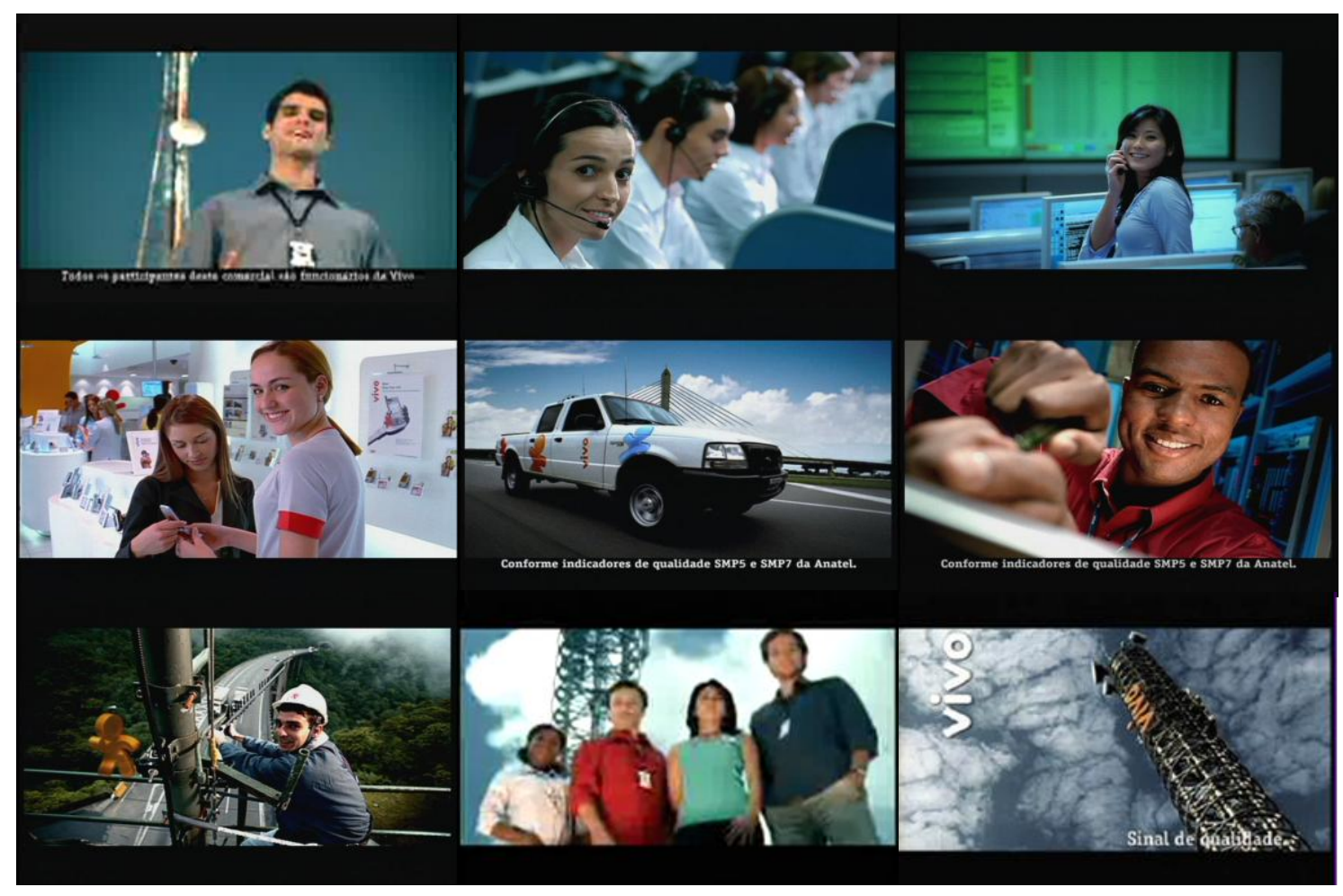

Ilustração 48 - Comercial de sequência da $1^{\text {a }}$ fase de comunicação do novo posicionamento Fonte: Material disponibilizado pela empresa, adaptado pelo autor

A seguir transcrevem-se também as falas dos colaboradores neste comercial.

"A Vivo tem a melhor qualidade de ligação entre todas as operadoras segundo os indicadores de qualidade da ANATEL.Mas isso não é sinal de que estamos satisfeito, a Vivo ainda tem muito o que melhora; e vamos continuar mudando para atender você cada vez melhor.Implantamos nossa rede GSM, simplificamos os planos, reduzimos os preços e demos mais opção de escolha.Isso tudo é sinal de 
mudança, porque para a Vivo não basta fazer a melhor ligação; a Vivo quer ser a melhor, para você. Vivo, sinal de qualidade."

Ainda para esta primeira fase foram veiculados anúncios seqüenciais de página inteira nos principais jornais e revistas do Brasil, seguindo a mesma linha do discurso e prestação de contas dos comerciais. Este mesmo conteúdo foi adaptado para as comunicações interna, com os colaboradores e nos demais canais externos, como lojas, internet e marketing direto.
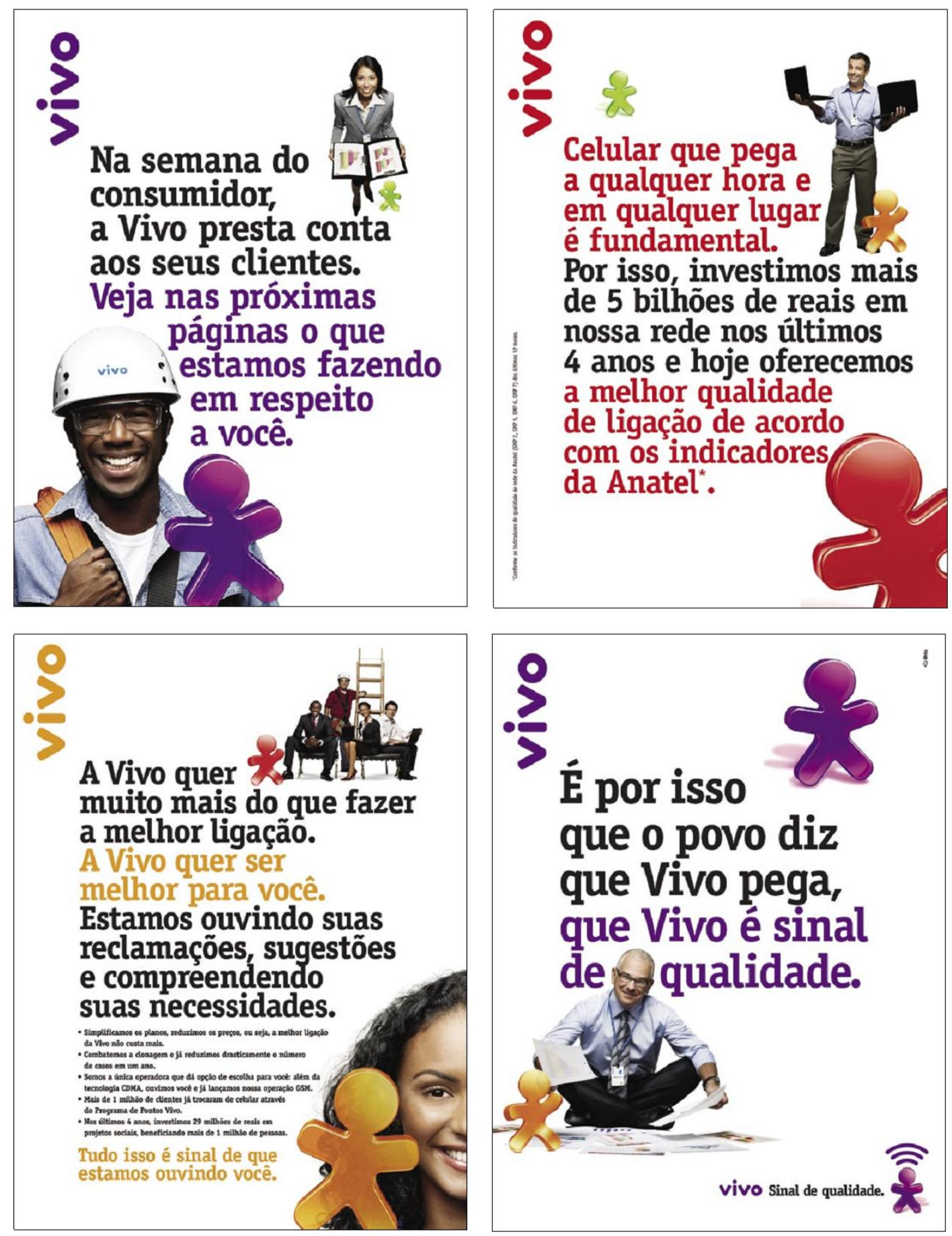

Ilustração 49 - Anúncio impresso da $1^{\text {a }}$ fase de comunicação do novo posicionamento Fonte: Material interno da empresa 
Na segunda fase de comunicação, a campanha publicitária teve um apelo mais emocional e poético e buscou marcar a ideia do novo posicionamento: sinal de qualidade. Através de um jingle, o comercial explorou situações cotidianas dos milhões de clientes da operadora, como bate papo entre amigas, profissionais trabalhando, famílias comemorando, demonstrando a presença do telefone celular, em todos os momentos em que se precisa estar conectado. $\mathrm{O}$ objetivo era mostrar que somente a Vivo podia oferecer essa possibilidade com a qualidade que se deseja.

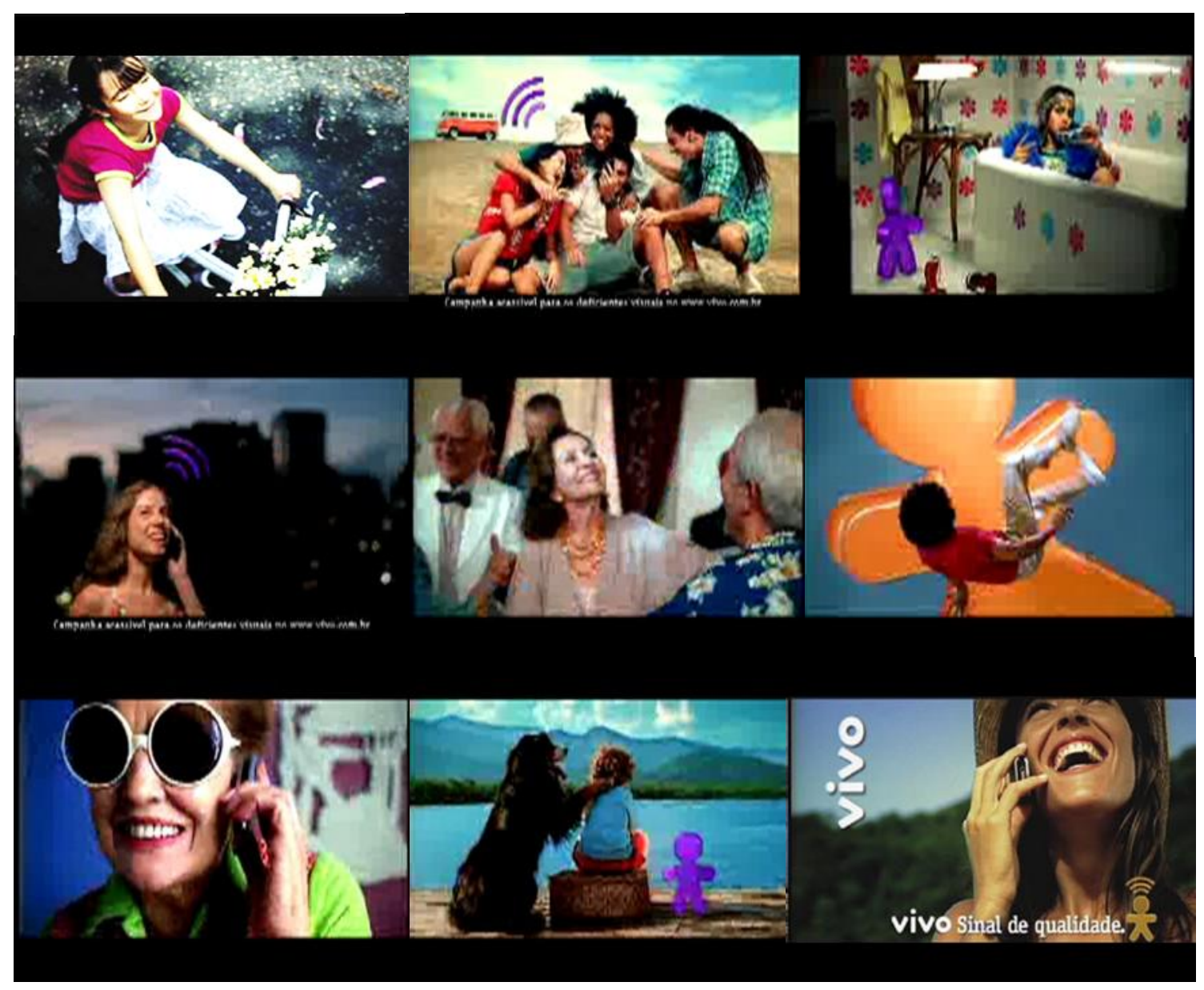

Ilustração 50 - Comercial de abertura da $2^{\mathrm{a}}$ fase de comunicação do novo posicionamento Fonte: Material disponibilizado pela empresa, adaptado pelo autor

A seguir, transcrição da letra da canção (jingle) deste comercial.

"Nuvem é sinal de chuva, coração é sinal de amor,relógio é sinal de tempo, campainha é sinal que você chegou... Abraço é sinal de amigo,primavera é sinal de flor, riso é sinal de alegria e Vivo é sinal que você ligou. Luzé sinal de vida, sol é sinal de calor, beijo é sinal de carinho. Sábado é sinal de festa,noite é sinal que o mundo girou, saúde é sinal de distância. E Vivo é sinal que você ligou, que você ligou. Vivo, sinal de qualidade." 
Os anúncios impressos desta fase, em jornais e revistas, também se concentraram nas diversas formas de desenvolver o conceito de sinal de qualidade no cotidiano das pessoas.
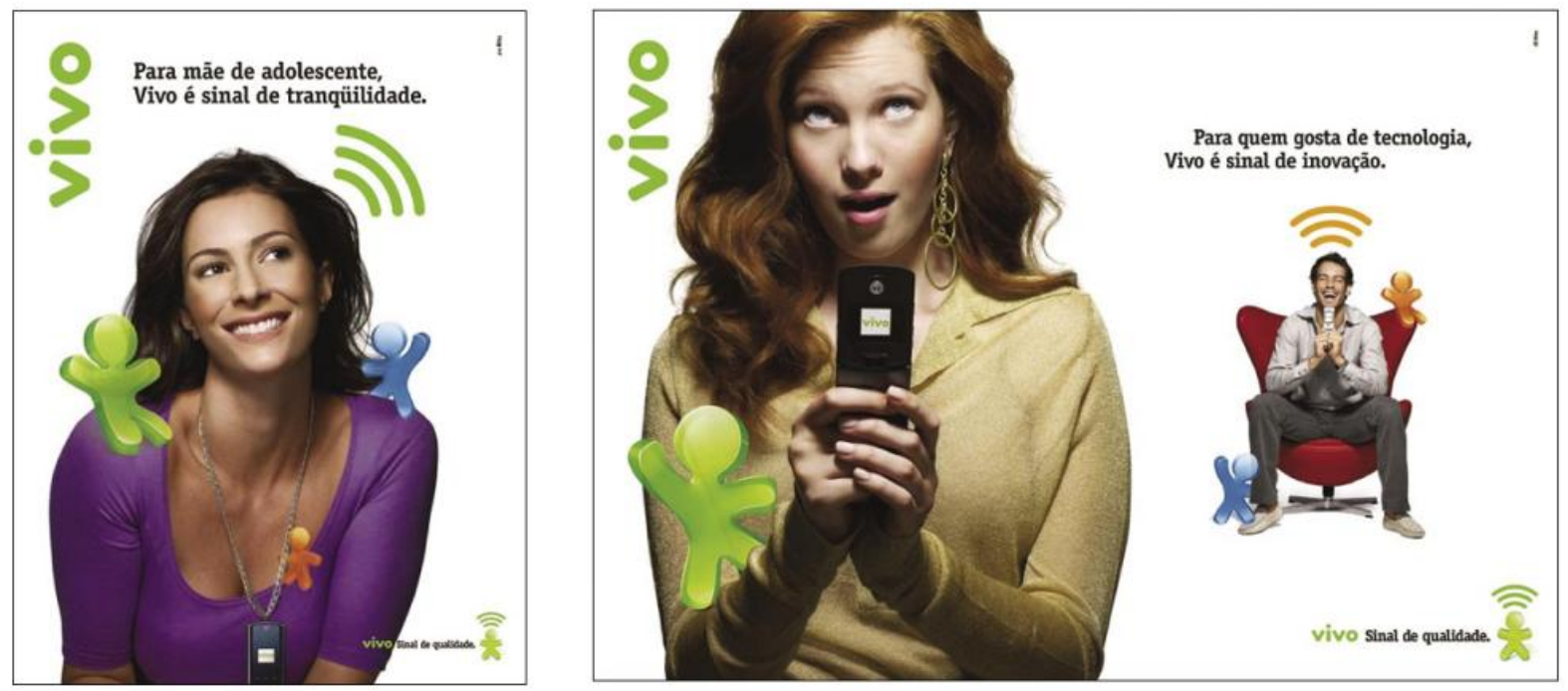

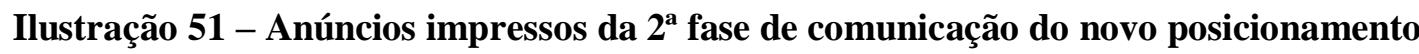
Fonte: Material interno da empresa

$\mathrm{Na}$ continuidade da estratégia, a operadora desenvolveu as campanhas de varejo, com a preocupação de manter a consistência na comunicação. A primeira delas foi realizada no dia das mães, importante data comercial para o varejo brasileiro. Nessa ocasião, a Vivo lançou um novo formato de comunicação, diferenciando-se na categoria ao utilizar uma linguagem transparente e de fácil compreensão com um porta-voz da marca, o apresentador de vendas na TV, Luiz Antonio Galebe, com a intenção de conferir o caráter de "bom negócio" aos serviços e ofertas da empresa.

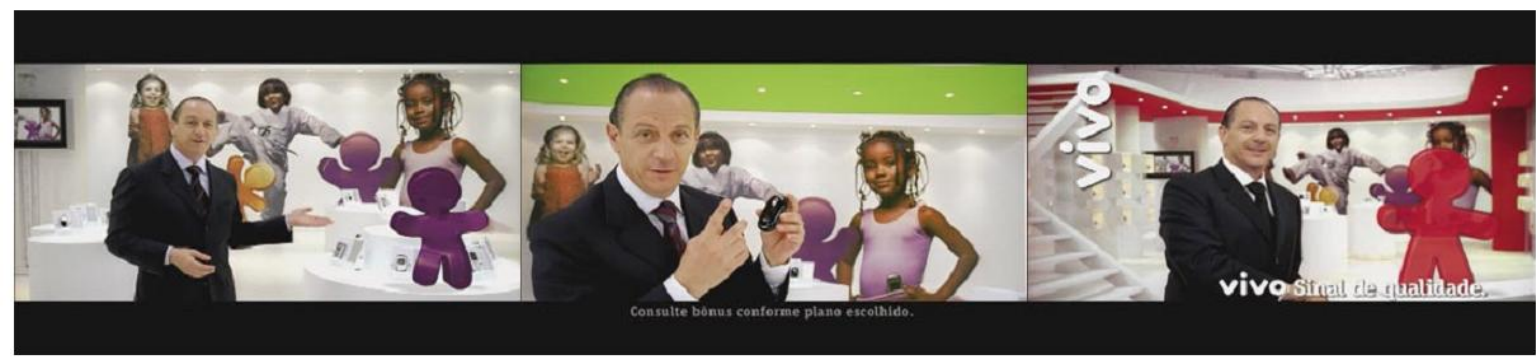

Ilustração 52 - Comercial do novo formato de comunicação para serviços e ofertas Fonte: Material disponibilizado pela empresa, adaptado pelo autor

As campanhas de aquisição realizadas durante o ano sustentaram uma comunicação que combinava a oferta do portfólio de planos pós e pré-pagos com lançamentos de celulares de última geração, exclusivos e inovadores. Vários desses aparelhos tiveram campanhas 
segmentadas, com foco em clientes de alto valor ou no público jovem, de acordo com suas características ou com os conteúdos exclusivos embarcados.

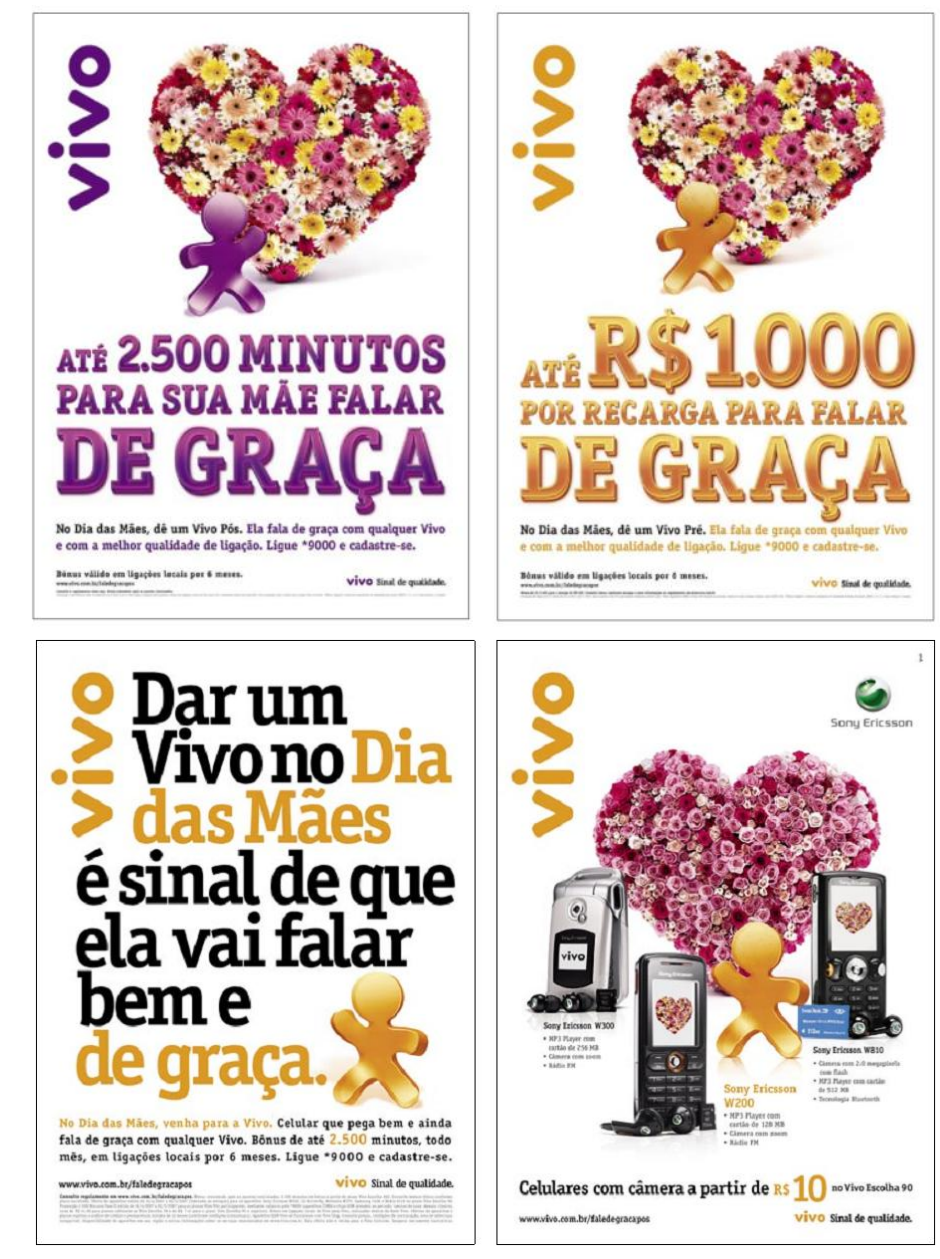

Ilustração 53 - Anúncios do novo formato de comunicação para serviços e ofertas Fonte: Material interno da empresa

Os clientes pré-pagos receberam também o reconhecimento e a valorização da companhia. Em agosto, foi lançado um formato de comunicação específico para esse público, com mensagens simples, diretas e focadas em benefícios. Na fase inicial, a campanha apresentou as diversas vantagens estruturais que a Vivo oferece para os clientes e, logo em seguida, entrou com a promoção " $1 \mathrm{~min}=\mathrm{R} \$ 1$ de bônus".

Para o segmento corporativo, segundo os entrevistados, a estratégia de comunicação adotada em 2007 buscou agregar sinergia com o posicionamento e consistência, com mensagens de fácil entendimento, que remetiam aos aspectos de velocidade, praticidade e conectividade. Assim, a prioridade para a comunicação da Vivo Empresas foram as soluções corporativas e os lançamentos de aparelhos multifuncionais. 


\subsection{4 "Praça": distribuição e logística}

Antes de se tratar propriamente das mudanças observadas no "P" de praça do composto de marketing da operadora, vale comentar brevemente sobre o modelo de distribuição e logística usual das operadoras de celular no Brasil.

O modelo prioritário de atendimento e comercialização, ou seja, a forma de distribuição se dá a partir de lojas próprias das operadoras nas quais se disponibilizam não apenas a compra de aparelhos (celulares, placas, modens), mas também a habilitação de planos, compra de serviços adicionais, compra de recarga, além do atendimento presencial. Neste caso a logística é da própria empresa, e basicamente se realiza a movimentação de elementos referentes apenas aos aparelhos e materiais de comunicação, já que o serviço em si não é estocado ou movimentado. Tais lojas localizam-se em shoppings, boulevards, lojas de rua ou quiosques em feiras, eventos, centros comerciais, entre outros.

No outro extremo está a distribuição por canais indiretos, que são geralmente varejos. Nesta modalidade, à época, a grande maioria dos varejistas efetuava apenas a venda dos aparelhos, sendo necessário ao cliente efetuar a habilitação da linha por contato ao call center ou dirigirse a uma loja da operadora. Normalmente, a operadora contava com quiosques dentro de grandes redes varejistas com um promotor de vendas.

Intermediariamente consideram-se ainda as revendas: lojas especializadas em tecnologia ou telecomunicações, que atuavam tanto de forma exclusiva com a operadora, como de forma não exclusiva e efetuavam a maioria das atividades que a loja própria também realizava.

Além disso, a grande capilaridade de distribuição advinha dos pontos de recarga, onde o cliente podia comprar créditos para o pré-pago, por meio de aquisição de cartão de recarga ou recarga eletrônica. Entre os principais estabelecimentos, citam-se bancas de jornal, farmácias, padarias, postos de gasolina, lotéricas, bares e restaurantes, entre outros.

Além destes pontos, ainda somam-se a loja virtual, de acesso pela internet, nacionalmente e um televendas, com acesso telefônico, pelo call center.

Ao final de 2007, a Vivo possuía 296 pontos de venda próprios, sendo 294 lojas e quiosques, 1 loja virtual nacional e 1 televendas nacional. As lojas próprias e quiosques estavam distribuídos da seguinte maneira: 89 em São Paulo, 49 nos Estados do Rio de Janeiro e 
Espírito Santo, 32 no Rio Grande do Sul, 35 nos Estados do Paraná e Santa Catarina, 25 nos Estados da Bahia e de Sergipe e 64 nos Estados das Regiões Centro-Oeste e Norte.

A Loja Virtual, que funcionava 24 horas por dia em todos os Estados de atuação da Vivo, passou a atuar nacionalmente em outubro, chegando aos últimos 7 Estados onde ainda não estava presente (Acre, Amapá, Amazonas, Maranhão, Pará, Rondônia e Roraima). Nos demais Estados a Loja Virtual atuou durante todo o ano. Vale destacar o crescimento de $446 \%$ nas vendas deste canal em 2007 quando comparado ao ano anterior.

Somando-se aos 7.962 pontos de rede de credenciados - varejo e revendas - a Vivo manteve a liderança, totalizando 8.258 pontos de atendimento. Complementando, com os pontos de recarga, os serviços da operadora estavam disponíveis em 365.798 ao todo. Recargas eletrônicas também passaram a poderem ser feitas em diversos bancos.

Como indicado no início deste capítulo, considera-se que o nível de impacto neste item do composto de marketing foi relativamente baixo em função das mudanças de tecnologia e de posicionamento.

De fato, a única mudança prática ocorrida neste sentido foi motivada pela introdução da tecnologia GSM. Um novo portfólio de aparelhos GSM passou a ser comercializado, em paralelo ao portfólio de aparelhos CDMA, o que de certa forma, aumentou a complexidade de gestão de estoques e exposição nas lojas, de negociação com varejos e revendas e do processo de logística em geral.

Além disso, o fato de os aparelhos GSM funcionarem a partir de um chip (sim card), este passou a ser um item tangível adicional que a operadora passou a gerir e distribuir não apenas por meio de seus canais próprios, mas principalmente através dos canais de maior capilaridade, como os pontos de recarga.

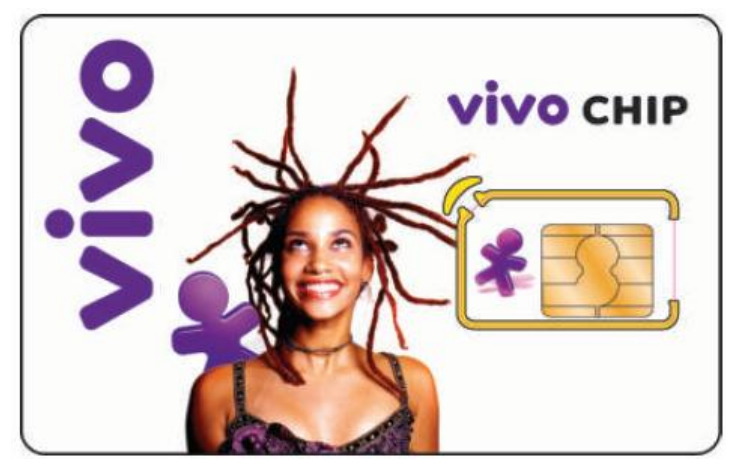

Ilustração 54 - Face do Vivo Chip, com o novo sim card GSM Fonte: Material interno da empresa 
O sim card da operadora foi lançado com o nome "Vivo Chip", com identidade própria da marca, ampliando a visibilidade e atratividade da empresa principalmente junto a não-clientes.

Outros fatores cruciais tiveram também impacto, em maior e menor nível, e estão de certa forma relacionados aos ambientes de comercialização e exposição de serviços e aparelhos. Estes fatores serão discutidos nos subtópicos a seguir, respeitando o modelo de mix de marketing de serviços considerado para este estudo.

\subsection{5 "Physical surroundings": instalações}

A exemplo do "P" de praça, pode-se considerar que o impacto em instalações teve um nível baixo em função das mudanças de tecnologia e de posicionamento. Ou seja, foram ajustes sutis nas evidências físicas que não necessariamente representaram grandes rupturas com os padrões visuais vigentes.

Nas lojas próprias da operadora, basicamente foi dada razoável visibilidade à nova assinatura de posicionamento "Vivo. Sinal de qualidade", que passou a estar presente nas fachadas das lojas e em algumas das peças de exposição de aparelhos, como mostra a ilustração 55.
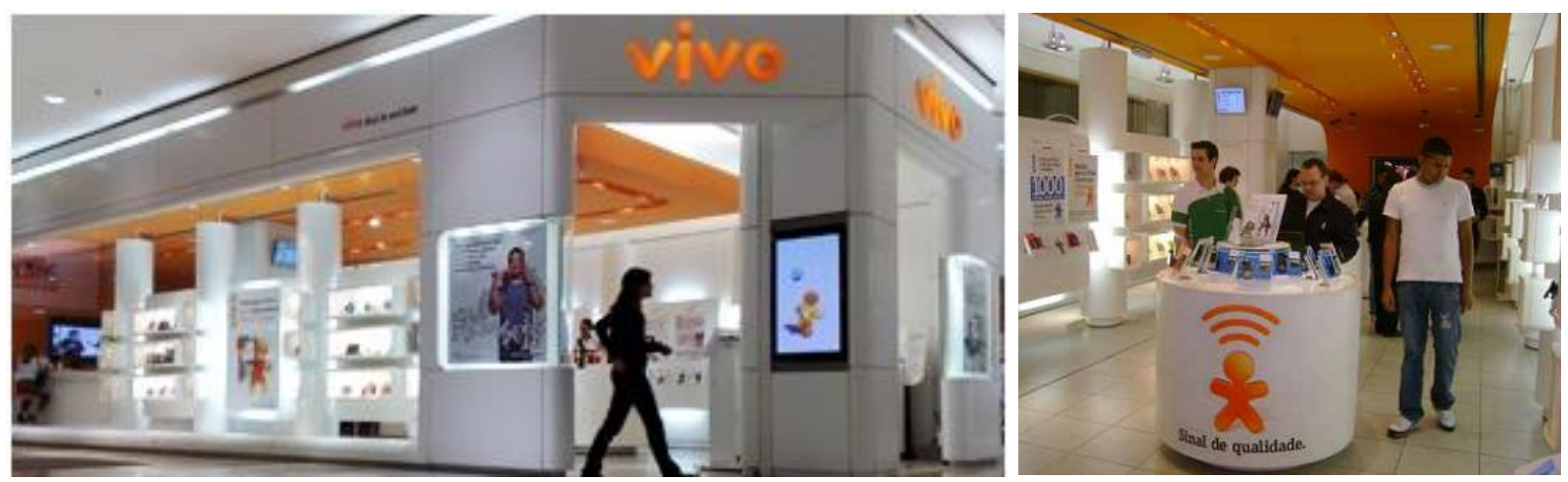

Ilustração 55 - Nova assinatura de posicionamento aplicada nas lojas da operadora Fonte: Material interno da empresa

Além disso, o reflexo da mudança tecnológica foi igualmente sutil, com pouco efeito nas evidências físicas. Apesar de que ambos os portfólios CDMA e GSM eram comercializados na loja, não houve nenhum grande artifício visual na exposição de aparelhos que segmentasse os aparelhos conforme a tecnologia. Em vez disso, os aparelhos, tanto CDMA como GSM eram segmentados na loja conforme um padrão atitudinal de uso por parte dos clientes (celulares nas categorias "prático", "multifuncional”, "high tech" e "fashion”). A indicação da 
tecnologia do aparelho era destacada no próprio display descritivo das funcionalidades e preço do modelo.

Por fim, enquanto instalações podem-se também considerar os escritórios funcionais da operadora em todo o Brasil, que durante todo o ano de 2007 foram ambientados com peças visuais (paineis, banners, gigantografias, entre outros) alusivas ao novo posicionamento, seguindo a temática visual da campanha publicitária que lançou o conceito.

\subsection{6 "Processos": atendimento e sistemas}

Avalia-se que o "P" de processos foi impactado de forma mediana pelas mudanças de tecnologia e de posicionamento.

Se forem considerados todos os processos sistêmicos internos para entrega das soluções de rede para o uso de voz e dados pelos clientes, obviamente deve-se dizer que o impacto da mudança de tecnologia para o GSM fora muito alto. Porém, o que se convencionou analisar dentro do "P" de processo são os outros processos da empresa, que não diretamente ligados à rede (questão que já fora considerada no "P" de produto) e que foram impactados positiva ou negativamente com a mudança de tecnologia.

Segundo os entrevistados, o processo mais positivamente influenciado pela mudança para o GSM foram os processos de habilitação e de troca de aparelhos. Com a facilidade do uso do sim card GSM (Vivo Chip), nas lojas e no call center tornou-se mais simples e rápido a troca de aparelhos. Com o GSM, o próprio cliente passou a poder realizar a troca de aparelho dentro de uma mesma linha, bastando apenas trocar o sim card, carregando junto todas as informações da linha, com sua agenda de contatos

Este era um procedimento considerado incômodo no CDMA, sendo necessário o contato com a central da operadora para uma reprogramação sistêmica a cada novo aparelho que o cliente desejasse utilizar. O mesmo raciocínio é válido para habilitação de novas linhas nas lojas, pois muitas vezes a ativação da linha no sim card (GSM) era mais rápida que a programação de uma nova linha no aparelho (CDMA).

Ainda referente ao processo de mudança da tecnologia GSM, na fase de lançamento foi disponibilizado o serviço de ligação gratuita par ao número *9001 em que o cliente dava a sua opinião sobre o novo serviço, sempre que quisesse. Os clientes nas lojas eram incentivados a contribuir, com o objetivo de aperfeiçoamento contínuo da qualidade da rede e dos serviços. 
Do ponto de vista da mudança de posicionamento, os processos mais impactados com a nova visão de qualidade esperada em todas as interações com o cliente, foram os de atendimento. Logo no início de 2007, a empresa concluiu o projeto de unificação de sistemas de atendimento e todas as regionais da empresa passaram a trabalhar com os mesmos sistemas, diminuindo custos de treinamento, controle e manutenção.

Com isso, os canais eletrônicos registraram números significativos em 2007, com 65 milhões de transações on-line, sendo mais de 2 milhões som clientes corporativos. O volume mensal de e-mails tratados através do "Fale Conosco" foi de 50 mil. Os terminais de autoatendimento localizados em lojas próprias realizaram mais de 10 milhões de transações.

$\mathrm{Na}$ “Central de Relacionamento da Vivo", segundo os entrevistados, o grande projeto do ano foi a estruturação do novo modelo de atendimento, desenhado segundo uma estratégia de segmentação, de acordo com a rentabilidade dos clientes. Assim, a empresa passou a contar com operadores com conhecimento diferenciado, com plano de carreira, salário mais atraente e maior autonomia para solucionar problemas na linha de frente.

Essa maior autonomia levou à redução de $70 \%$ nos processos tramitados ao Back Office. Isso se traduziu em menor custo de tratamento e maior agilidade no atendimento, com positivos reflexos na satisfação dos clientes.

Por fim, por ocasião tanto da mudança de tecnologia como da mudança de posicionamento, outro importante gap resolvido, na opinião dos entrevistados, foi a consolidação da redução das fraudes. No ano de 2007 a fraude de clonagem foi reduzida em 96,51\%, representando um recorde histórico. Os processos para detecção de fraude de subscrição melhoraram significativamente, garantindo o cumprimento das metas estabelecidas com agilidade e maior assertividade da atividade.

\subsection{7 "Pessoas": colaboradores e atendentes em geral}

O último, mas não menos importante "P" a se avaliar é o de pessoas. Pôde-se perceber claramente que na opinião dos entrevistados esse foi um dos fatores mais impactados pelas mudanças de tecnologia e de posicionamento e, ao mesmo tempo, mais decisivo para que, de fato, as mudanças acontecessem e fossem tangibilizadas, por meio da gestão do composto de marketing como um todo. 
Em primeiro lugar, segundo os entrevistados, a mudança de tecnologia exigiu um nível de alinhamento e comprometimento interno nunca antes visto na empresa. A urgência e a necessidade de cumprir o cronograma de implantação da nova rede GSM em tempo recorde fez com que a forma de as áreas se comunicarem, se relacionarem e trocarem informações e acordassem decisões mudasse significativamente.

Ao mesmo tempo, para que todos tivessem as mesmas informações e pudessem se preparar nas diversas frentes de trabalho para o lançamento GSM (tais como tecnologia, canais comerciais, call center, comunicação, logística e áreas administrativas, entre outras), treinamentos específicos foram desenvolvidos, tanto para equipes de frente como gerenciais. os treinamentos envolveram mais de 15.000 pessoas nas linhas de frente. Tudo isso com acompanhamento e monitoria de qualidade para atestar a efetividade de quem foi treinado.

Segundo os entrevistados, foi realizada ainda uma força-tarefa para construção de uma capacitação para a equipe comercial estar apta a discursar sobre a mudança tecnológica e para aprender os processos de habilitação de linhas. A argumentação da equipe de vendas era considerada essencial para a credibilidade da mudança.

Para a construção dos treinamentos e materiais de merchandising no ponto de venda foram realizados diversos benchmarkings e foram estudadas pesquisas neste assunto. Havia a preocupação de como vender a mudança tecnológica sem fragilizar o CDMA, já que se havia optado pela estratégia de comercialização de ambas as tecnologias, pelo menos por certo tempo.

De forma geral, foi necessário rever a capacitação inicial da força de vendas e atendimento, tanto na argumentação comercial como no processo de vendas, sendo necessário que passasse a ser mais agressiva na captação de novos clientes, num momento em que tecnologia tendia a se tornar commodity. A forma de pensar e agir da força de vendas teve de ser reconstruída, de forma a poder responder aos questionamentos dos clientes de base e da concorrência quanto à mudança de tecnologia.

Segundo os entrevistados, entre as diversas metodologias diferenciadas utilizadas para os treinamentos estão as técnicas presenciais, teatro de vendas, e-learnings. Também foi criado um programa de excelência para acompanhamento da evolução das mudanças nos pontos de vendas, com a ativação de novos materiais de merchandising e execução de pesquisas no 
formato "cliente misterioso" para avaliação de pontos de melhoria junto às equipes de vendas e atendimento.

Por fim, no mesmo espírito de mobilização, ativada na empresa como um todo por ocasião do "Projeto W" (implantação da rede GSM), a mudança de posicionamento, na opinião dos entrevistados, veio a potencializar a sensação de transformação e de preocupação incondicional com a qualidade. O "mantra da qualidade", advindo com o posicionamento "Sinal de qualidade", passou a permear todas as atividades em curso, tornando-se critério mandatório para o desenvolvimento de qualquer novo projeto.

A atuação paralela do "Projeto Impulso", sob responsabilidade da área de planejamento estratégico da empresa estabeleceu um esforço coordenado entre as metas de Balanced Scorecard e a remuneração variável de todos os colaboradores, vinculando as necessidades da empresa e as expectativas das pessoas, visando ganhos mútuos.

\subsection{Resultados de negócios e de marca}

Para completar o panorama previsto de apresentação e análise deste estudo de caso, segue-se com o aprofundamento dos resultados obtidos pela empresa durante e após o período do evento-foco, buscando entender como evoluíram os principais indicadores relacionados às mudanças ocorridas, nos âmbitos financeiro, operacional e de marca.

\section{Mudança de tecnologia}

Para avaliação dos impactos com a mudança do CDMA para o GSM a empresa realizou, em julho de 2007, uma pesquisa quantitativa com clientes Vivo pré e pós-pagos de todo o Brasil, usuários do serviço na tecnologia GSM, com o intuito de avaliar a satisfação geral dos clientes. Foram 766 entrevistas ao total, com usuários do serviço há pelo menos um mês e foram considerados clientes que migraram da tecnologia CDMA para o GSM, clientes que migraram das operadoras concorrentes para a Vivo já com a tecnologia GSM, além de clientes "fresh" (que adquiriam seu primeiro celular).

A pesquisa mostrou que de forma geral os clientes estavam satisfeitos com a nova tecnologia GSM e os principais aspectos que justificavam a satisfação, segundo o instituto, estavam ligados à qualidade da ligação, sinal e imagem da operadora, principalmente entre os clientes pré-pagos que migraram da concorrência e os clientes fresh. As maiores críticas foram 
declaradas pelos clientes pós-pagos que migraram de CDMA e da concorrência. O gráfico 13 apresenta os resultados gerais da pesquisa.

\section{Gráfico 13 - Resultados gerais de satisfação do cliente com a nova tecnologia GSM}

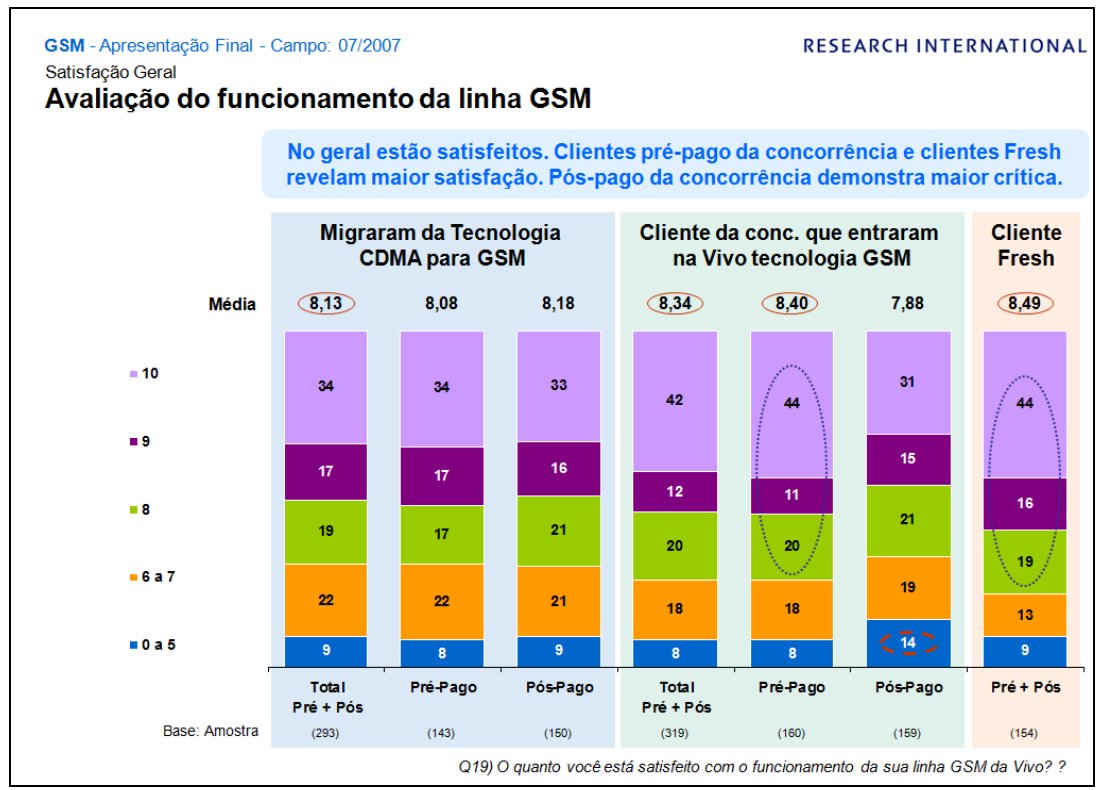

Fonte: Projeto GSM 2007 Research International, disponibilizado pela empresa

Especificamente em relação à qualidade de sinal, ao se comparar a qualidade de ligação da nova linha GSM com a linha anterior, os clientes que migraram da concorrência tendiam a avaliar melhor o novo serviço da Vivo. Os clientes que eram CDMA na operadora foram mais críticos e cerca de metade acreditavam que a qualidade estava igual ou pior.

\section{Gráfico 14 - Opinião do cliente sobre a qualidade de sinal com a nova tecnologia GSM}

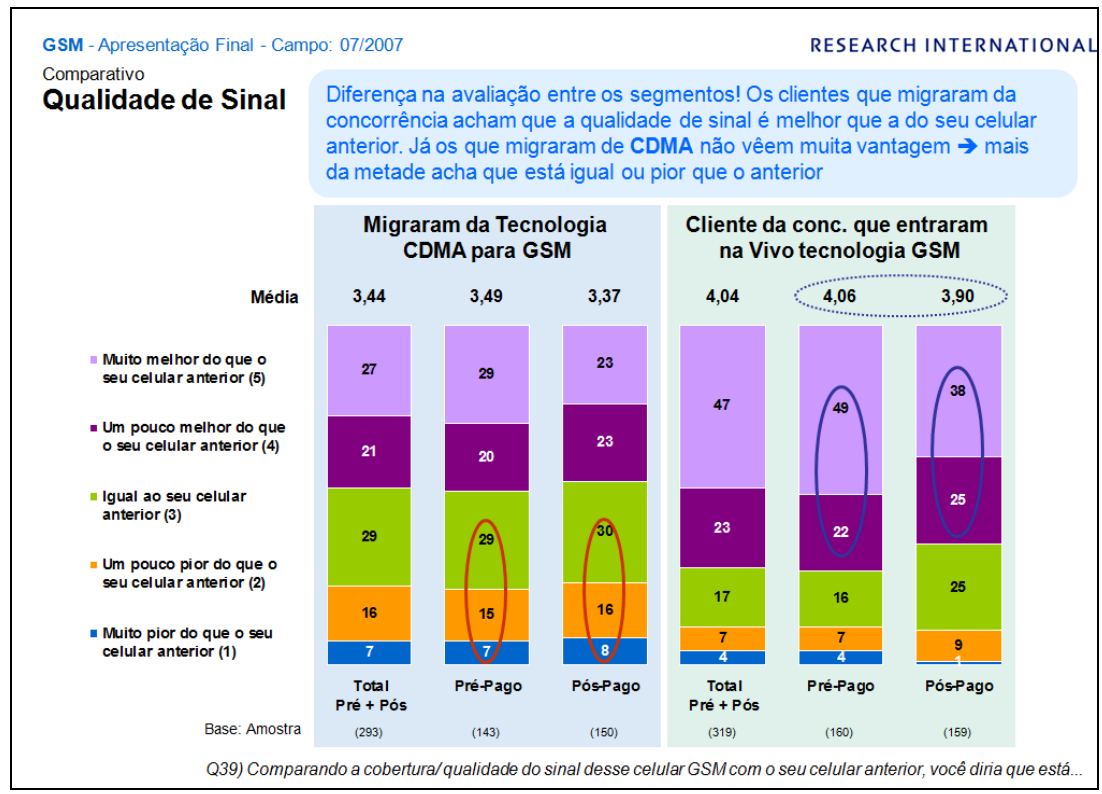

Fonte: Projeto GSM 2007 Research International, disponibilizado pela empresa 
Ainda segundo a pesquisa, o principal motivador de escolha pela tecnologia GSM foi o modelo de aparelho para todos os segmentos e principalmente o preço do aparelho foi considerado atrativo.

Por fim, pode-se dizer que, na opinião dos entrevistados, a imagem da Vivo melhorou com a introdução do GSM, principalmente entre os clientes que migraram da concorrência (e em maior peso, os pré-pagos). Para os clientes que já eram CDMA na operadora, a contribuição para melhoria de imagem da marca foi sutil, como mostra o gráfico 15.

\section{Gráfico 15 - Opinião do cliente sobre a imagem da Vivo com a nova tecnologia GSM}

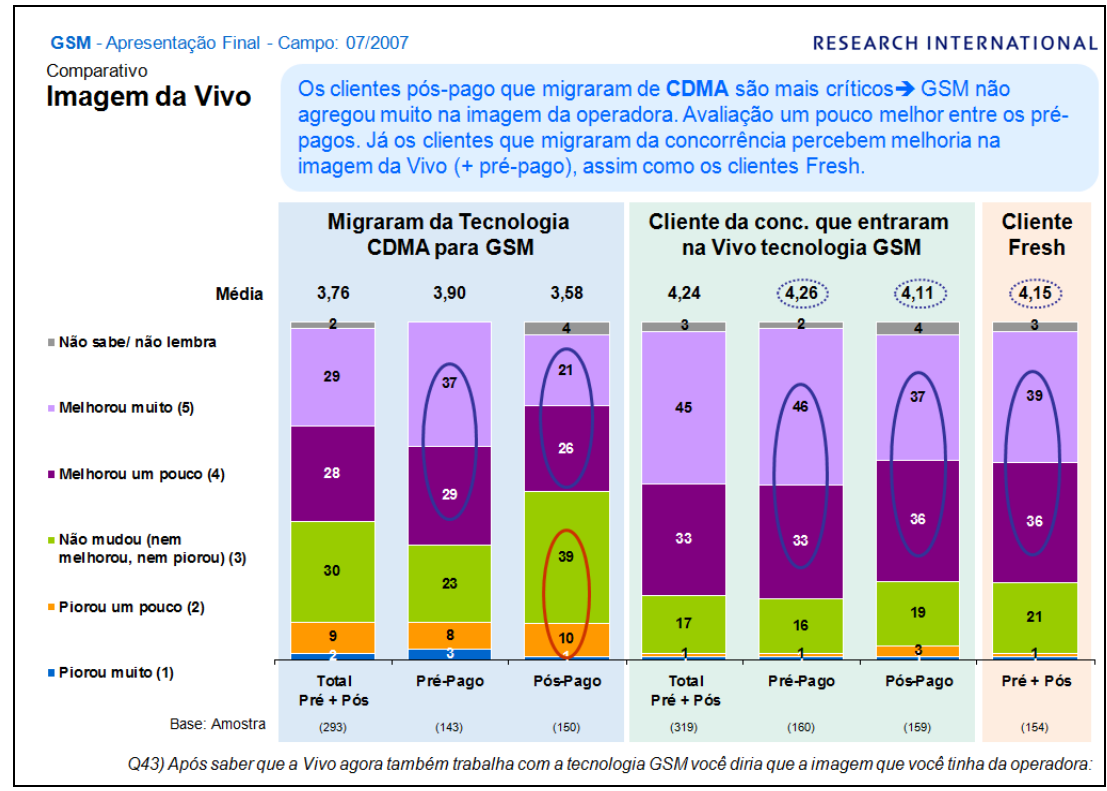

Fonte: Projeto GSM 2007 Research International, disponibilizado pela empresa

\section{Mudança de posicionamento}

Antes de se tratar especificamente a evolução dos principais indicadores de marca, vale destacar que a campanha publicitária de lançamento do novo posicionamento "Vivo. Sinal de qualidade." foi pré-testada qualitativamente a fim de se observar a compreensão e opinião do cliente sobre as mensagens. Foram 12 focus groups com clientes da operadora Vivo e concorrentes, nas cidades de São Paulo, Rio de Janeiro, Salvador e Curitiba.

As principais conclusões da pesquisa, apresentadas na ilustração 56, mostraram a receptividade do público às mensagens e compreensão do discurso da operadora, estruturado em fases como apresentado anteriormente. 


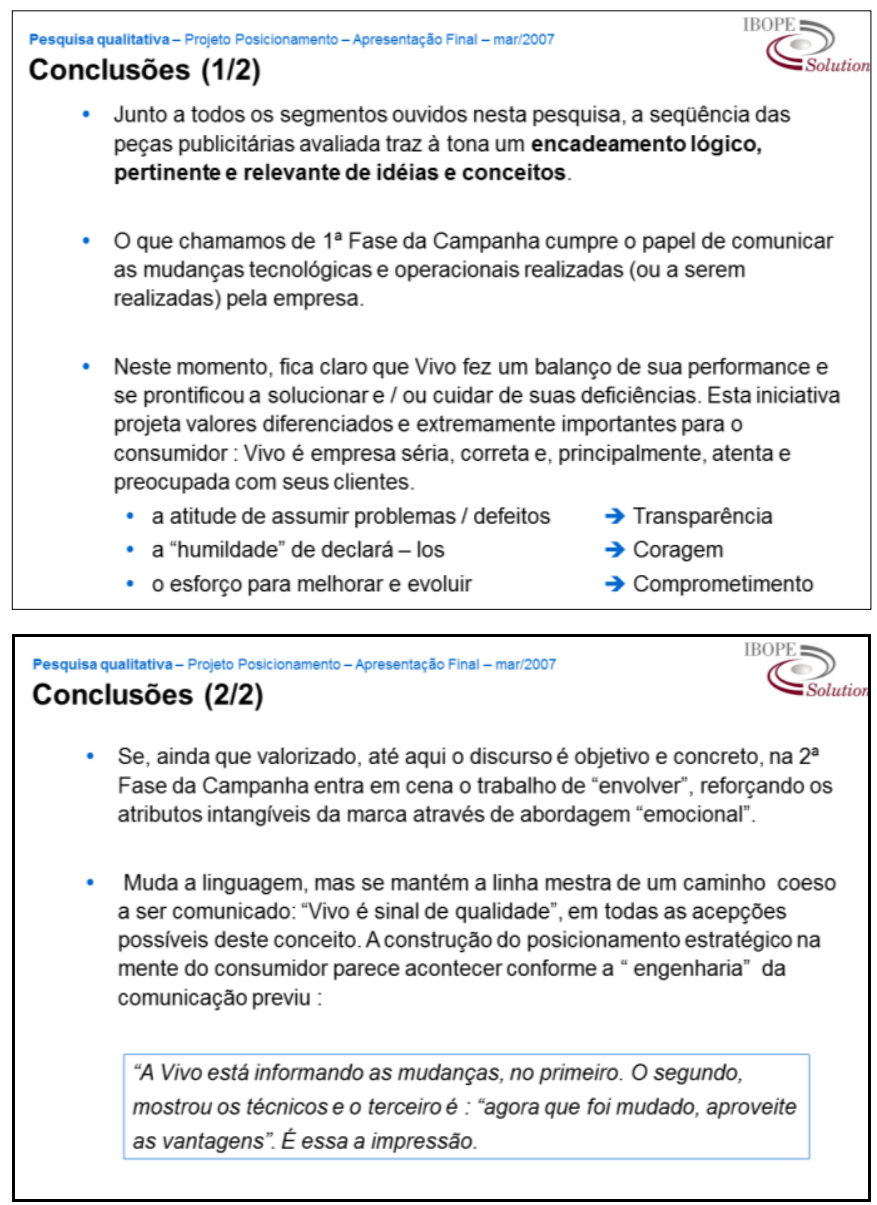

Ilustração 56 - Opinião do cliente sobre a campanha de lançamento do novo posicionamento Fonte: Projeto Posicionamento Ibope Solution, disponibilizado pela empresa

O reflexo do conjunto de mudanças ocorridas sobre a imagem de marca é apresentado no gráfico 16.

Gráfico 16 - Evolução da imagem de marca com o novo posicionamento

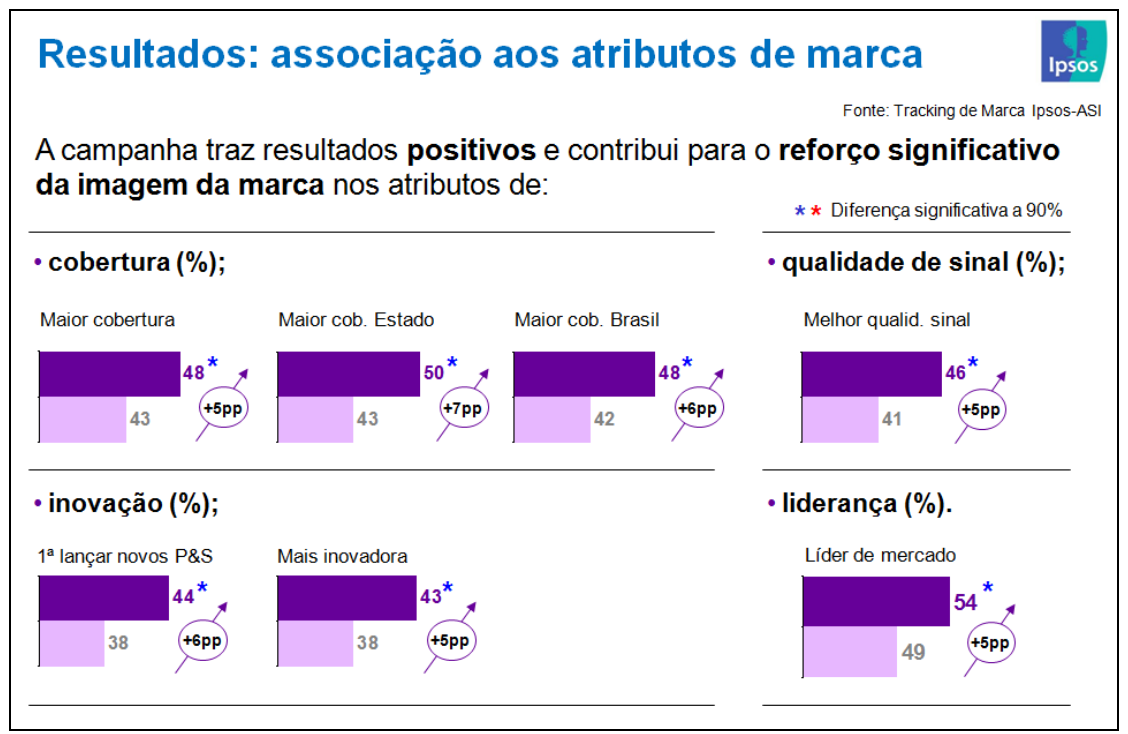

Fonte: Tracking de marca Ipsos ASI, disponibilizado pela empresa 
Como se pôde perceber, o tracking de marca realizado nacionalmente pelo instituto para a operadora indicou aumento significativo (diferença significativa a 90\%) da associação da marca Vivo aos atributos mais relevantes para o novo posicionamento: cobertura, qualidade de sinal e inovação, além de se manter a vantagem no atributo de liderança.

Além disso, neste mesmo estudo, conforme exposto no gráfico 17, Vivo aparece com a maior lembrança de marca e de propaganda do mercado de telefonia celular, além de ser a marca preferida pela maioria dos clientes.

Gráfico 17 - Desempenho nos principais indicadores de saúde de marca

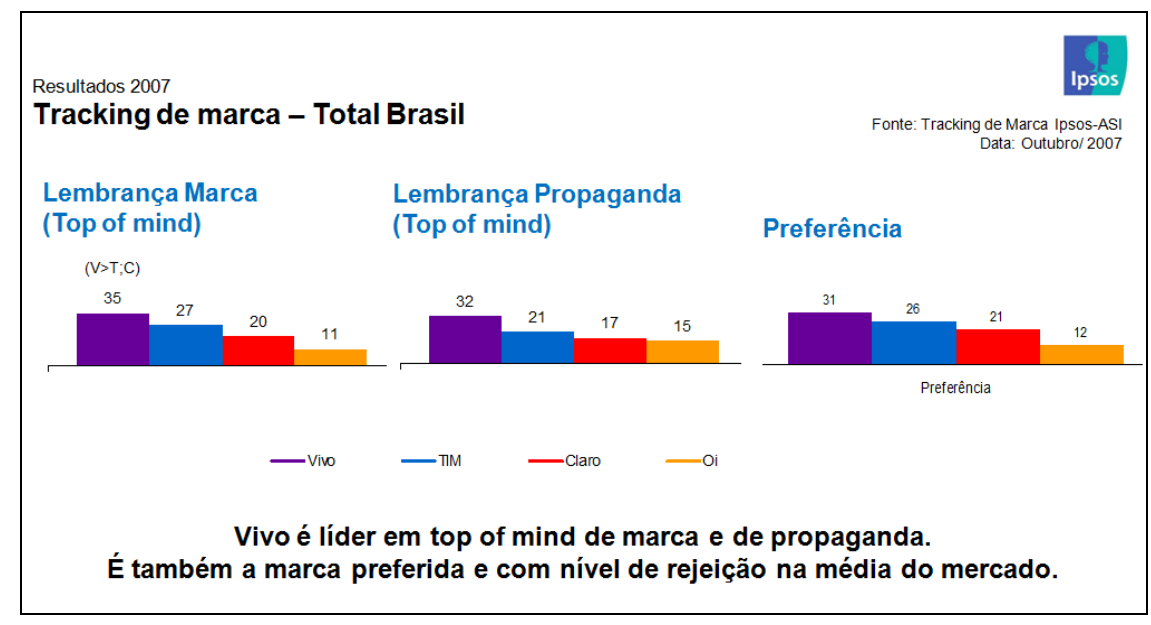

Fonte: Tracking de marca Ipsos ASI, disponibilizado pela empresa

E em brand equity,o gráfico 18 mostra que a marca Vivo se destaca principalmente nas dimensões de popularidade e qualidade; esta última a principal almejada pela empresa.

Gráfico 18 - Desempenho nos principais indicadores de equity de marca

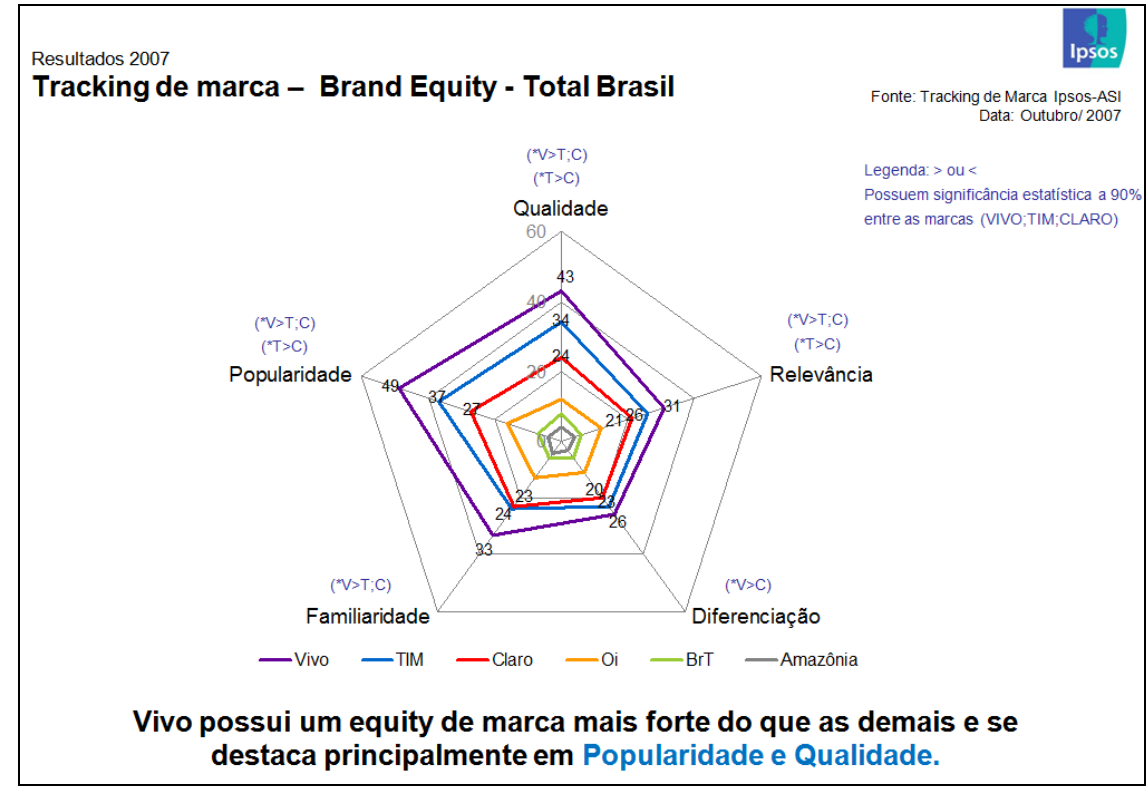

Fonte: Tracking de marca Ipsos ASI, disponibilizado pela empresa 
Ainda do ponto de vista da marca, a Vivo foi premiada pelo case de novo posicionamento de marca nos eventos ocorridos em 2007: "Top de Marketing ADVB", "Marketing Best" e "Prêmio About de Comunicação Integrada".

Nos principais rankings nacionais de marca, a operadora Vivo também figurou na liderança. Em 2007, foi eleita pelo $4^{\circ}$ ano consecutivo a marca mais confiável do Brasil em ranking do instituto IBOPE, na categoria telefonia celular, ampliando neste ano a vantagem para o segundo colocado em 8 pontos porcentuais (alcançando 33\% vs. 25\% do segundo colocado).

E, finalmente, no que tange ao valor de marca, no ranking 2007 da consultoria Brand Finance, Vivo manteve o posto da marca mais valiosa do mercado de telecomunicações brasileiro, alcançando o valor de $\mathrm{R} \$ 2,25$ bilhões. $\mathrm{O}$ aumento do valor de marca em relação ao ano anterior fora de $28 \%$ (em 2006 a marca valia R\$ 1,75 bilhões, no mesmo ranking).

\section{Resultados operacionais}

Segundo o relatório de administração da empresa, a base de clientes ao final do primeiro trimestre de 2008 (um ano após a mudança de posicionamento) foi de 34.323 mil clientes, sendo mais de 14,6 milhões na tecnologia GSM. O crescimento em relação ao primeiro trimestre de 2007 foi de $18,2 \%$.

As adições líquidas (diferença entre o total de clientes que entraram e que saíram da operadora) no primeiro trimestre de 2008 totalizaram 839 mil novos clientes, com um market share de adições líquidas de 22,2\% na sua área de atuação, mantendo a liderança de mercado, revertendo o cenário do ano anterior, quando a Vivo estava ainda iniciando suas operações com a tecnologia GSM. Segundo a empresa, as ativações na tecnologia GSM, que representam $83 \%$ das ativações totais, contribuíram para o crescimento consistente.

O churn, importante medida da indústria de telecomunicações (representa o porcentual de clientes que deixam a empresa em relação à base de clientes ativos), foi de 2,6 \% no período, e ficou estável em relação ao mesmo período do ano anterior. Segundo a empresa, isso demonstrou que as ações para fidelização e ativação da base de clientes mostravam-se eficientes, mesmo com a intensa atividade comercial registrada entre os períodos.

O gráfico 19 representa a reversão de tendência da empresa no período corrente do ano de 2007, aumentando participação no share de altas (captação de novos clientes) e reduzindo o churn (saída de clientes). 
Gráfico 19 - Evolução de resultados operacionais da empresa

\section{Resultados de negócio: 2007 vs. 2006}

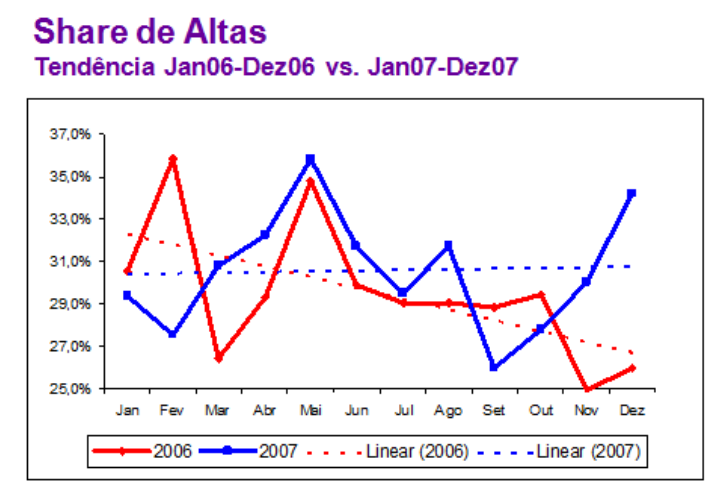

Churn

Tendência Jan06-Dez06 vs. Jan07-Dez07

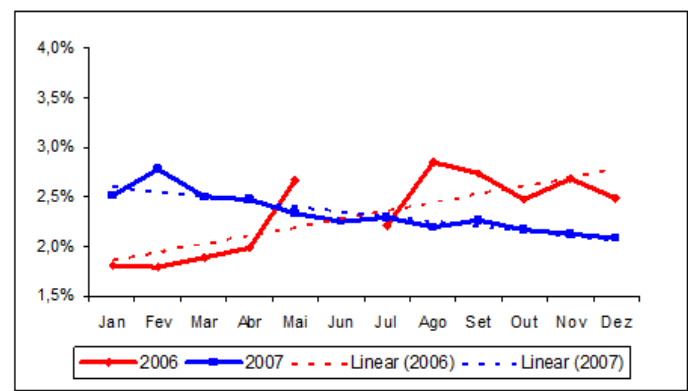

Tendência de aumento no share de altas e de queda no churn em 2007 em comparação com tendência oposta em 2006 no mesmo período.

Fonte: Material interno da empresa

Conforme já apresentado no tópico 2.4.2 deste trabalho, o market share geral de mercado da empresa na sua área de atuação em 2007 foi de 30,9\%, representando uma redução de 1,6 pontos porcentuais em relação ao anterior. Segundo a empresa, ainda que tenha havido uma redução nesse indicador, o número de novos clientes que entraram para a base da operadora foi significativo (quase 5 milhões de novos clientes) e representou uma redução na tendência de queda do market share da empresa nos anos anteriores.

\section{Resultados financeiros}

Para finalizar, apresenta-se a evolução dos principais resultados financeiros da empresa no período.

Do ponto de vista das ofertas, vale ressaltar os resultados do segmento pré-pago, que apresentaram aumento de $21,8 \%$ da recarga líquida em relação ao ano de 2006. Segundo a empresa, dentre todas as ações veiculadas durante o ano, contribuiu fortemente o incentivo da campanha "Receba e Ganhe", referente à promoção de bônus entrante, que oferecia ao cliente pré-pago $\mathrm{R} \$ 1$ a cada minuto em ligações recebidas de qualquer celular ou fixo.

A receita líquida total apresentou um crescimento de 16,9\% em relação ao primeiro trimestre de 2007 , impulsionada pela evolução de $15,8 \%$ na receita de serviços. Segundo a empresa, o 
aumento deveu-se principalmente ao incentivo ao uso e promoções, pelas campanhas segmentadas e do aumento no valor médio de recargas por cliente.

A receita de dados acrescido dos serviços de valor agregado no primeiro trimestre de 2008 representou $10,4 \%$ da receita de serviços e teve um aumento absoluto de $47,7 \%$ em relação ao primeiro trimestre de 2007. Os principais motivadores desse crescimento foram, de acordo com a empresa: forte incremento da receita dos serviços Play, Java, SMS, bem como aumento do parque de clientes de dados com acesso por modem e smartphone; aumento da utilização de SMS pessoa a pessoa, como conseqüência do aumento de recargas com serviço e das ativações de planos pós-pagos com vantagens de dados; promoção de estímulo ao uso de mensagens instantâneas (ações de interatividade em TV e outras mídias) e realização de novas parcerias com integradores e provedores de conteúdo.

O EBITDA (resultado antes dos juros, impostos, depreciações e amortizações) no primeiro trimestre de 2008 foi de $\mathrm{R} \$ 961,2$ milhões um aumento de 27,0\% em relação ao primeiro trimestre de 2007, resultando em uma margem EBITDA (EBITDA dividido pela Receita Operacional Líquida) de 28,8\%.

O resultado fora o maior registrado nos cinco trimestres anteriores e, segundo a empresa, refletiu o crescimento das receitas pelo aumento da base de clientes e o rígido controle dos custos. Contribuiu para essa evolução, de acordo com a empresa, o custo de mercadorias vendidas, explicada pela venda de aparelhos GSM que possuíam menor custo de aquisição.

O gráfico 20 consolida a evolução positiva do EBITDA e da margem EBITDA da empresa, a partir do ano anterior e posteriores ao evento-foco ocorrido em 2007.

\section{Gráfico 20 - Evolução do EBITDA e da margem EBITDA da empresa}

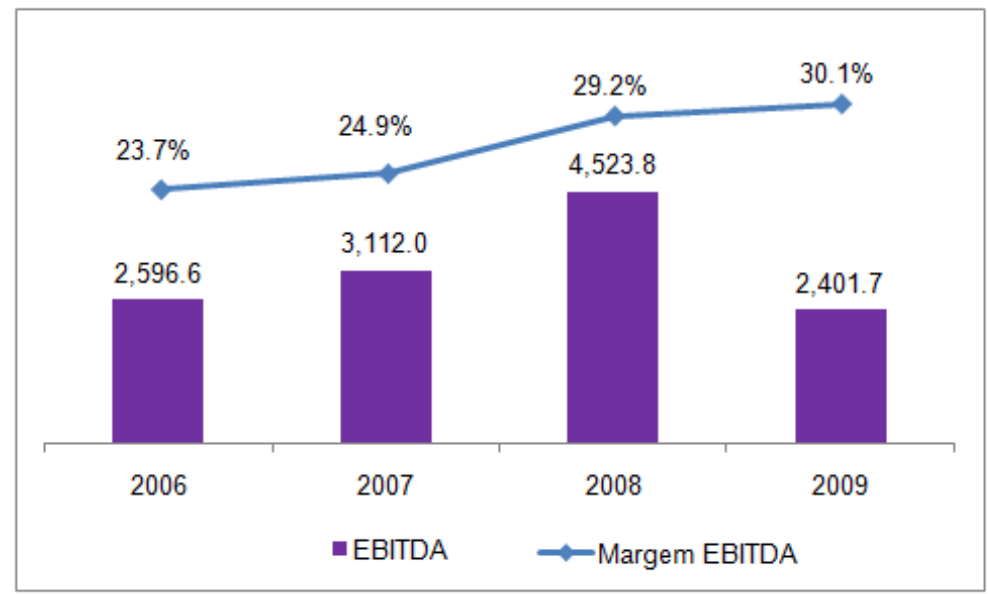

Fonte: Relatório de administração da empresa 


\section{CONSIDERAÇÕES FINAIS}

\subsection{Conclusões do estudo}

Nesta etapa final, objetiva-se aprofundar o entendimento dos resultados de pesquisa, à luz dos conceitos teóricos revisados, de forma a concluir o trabalho, revisitando os objetivos propostos.

Partindo-se do objeto de análise que este trabalho se propôs observar, marcas de serviços, exemplificada pelo estudo de caso de uma do setor de serviços de telecomunicações brasileiro, pôde-se observar como as características distintivas de serviços, sobretudo a intangibilidade, adicionam complexidade ao processo de gestão de marketing nestes tipos de empresas (GRÖNROOS, 1995; LOVELOCK; WRIGHT, 2001; ZEITHAML; BITNER; 2003; HOFFMAN et al., 2009). No caso Vivo, especialmente, em que a proposta de valor é composta por itens intangíveis em sua maioria, mas com componentes tangíveis agregados, evidencia-se a complexidade de gestão, em que parte das entregas é provida diretamente pela empresa, utilizando-se de sua expertise e competências essenciais (infraestrutura de rede que gera o sinal das ligações, ofertas de planos, recarga e promoções, além dos serviços de valor agregado), mas também parte das entregas é realizada de forma intermediária, por meio de parceiros como os fornecedores de aparelhos (celular, placas, modens), que é justamente a parte mais tangível do serviço.

Neste mercado grande parte do sucesso advém do entendimento e da capacidade de gerenciar questões inerentes ao serviço, relacionadas à inseparabilidade e principalmente, à perecibilidade. Ainda que a parte tangível da prestação, relacionada a aparelhos, seja perfeitamente gerenciada quanto à estocagem e logística, a parte principal, da prestação dos serviços de voz e dados, é diretamente dependente da capacidade de rede da operadora. Ou seja, está relacionada à capacidade da infraestrutura de rede instalada - redes de transmissão e equipamentos e software (FRANSMAN, 2001), garantindo a adequação da capacidade de rede ao número de clientes e volume de ligações e uso de dados destes nos planos ofertados pela operadora. Por este motivo, critérios como qualidade de ligação são tão cruciais para a atuação de uma empresa de serviços de telecomunicação móvel, afinal o benefício básico deste tipo de serviços é poder falar e ser encontrado a qualquer momento, em qualquer lugar.

Cabe destacar ainda a dificuldade, advinda desta complementaridade de entregas tangíveis e intangíveis, diretas e indiretas, na questão preço. A determinação de custos reais das unidades 
de serviço e a relação preço / qualidade são complexas (ZEITHAML; BITNER, 2003), o que dificulta a criação de uma posição clara de marca nos atributos relacionados a preço.

Conforme observado na fundamentação teórica, a maior parte dos estudos em marketing de serviços no Brasil se concentrou em dois construtos: qualidade e satisfação, investigando o comportamento pós-compra de serviços (DA ROCHA; FERREIRA DA SILVA, 2006). Podese considerar que este estudo de certa forma contribuiu para ampliar a visão desse fenômeno a posteriori, ou seja, de como os clientes de serviços respondem de acordo com a satisfação com serviços do ponto de vista da qualidade, mas a preocupação maior foi em retratar, no âmbito do posicionamento, como a empresa planeja e estrutura a sua oferta de serviços em busca desses resultados. Do ponto de vista dos clientes, de forma análoga, observou-se não apenas como reage às ações da empresa - pós-compra - mas principalmente como forma suas opiniões e coopera para as decisões da empresa - pré-compra e consumo (HOFFMAN et al., 2009).

Desta forma, o estudo de caso da empresa Vivo permitiu descrever, com razoável grau de profundidade, por meio da análise de múltiplas unidades de análise integradas (YIN, 2010), o processo de gestão de marketing de forma ampla - da estratégia aos resultados - situando e enfocando o processo crítico em análise: o posicionamento de marketing.

Resgatando o objetivo geral de pesquisa, de estudar o posicionamento de marcas de serviços no setor de telecomunicações e como ele é afetado pela introdução de inovação disruptiva, agrega-se a preocupação de contribuir para a evolução desse campo de estudo, reconhecendo o papel da tecnologia da informação (SETH et al., 2005), cada vez mais desenvolvida nas empresas de serviços.

A questão da inovação disruptiva foi trazida ao estudo, pois geralmente trazem a um mercado uma proposição de valor muito diferente da disponível até então, alterando a natureza do mercado e de certa forma forçando as empresas a reconsiderarem as suas posições (CHRISTENSEN, 2000; PADGETT; MULVEY, 2007).

Em telecomunicações móveis, a tecnologia é a base da oferta de serviços e é um dos poucos mercados de serviços em que a questão da tecnologia empregada atinge o cliente, por meio da prestação e do discurso (publicitário e imprensa especializada), de forma decisiva para a opção e contratação do serviço. A polarização tecnológica CDMA x GSM teve relevância no Brasil, especialmente no momento de início das operações sob o novo regime do Sistema 
Móvel Pessoal, fase que precedeu o evento analisado nesse estudo de caso. Como amplamente apresentado, o caso estudado debateu a introdução da tecnologia GSM pela operadora Vivo, inicialmente em paralelo à tecnologia CDMA vigente, mas que no longo prazo veio a ser substituída de forma praticamente integral pela tecnologia GSM.

À luz dos conceitos teóricos, se confirma o caráter disruptivo que a tecnologia GSM apresentou em relação ao CDMA. O GSM, em sua introdução apresentou um desempenho inferior ao esperado pelos clientes (especificamente para aqueles que já tinham experiência com a tecnologia CDMA), os novos benefícios oferecidos não são valorizados pelos clientes tradicionais (no caso, o benefício da troca do chip, permitindo o uso de múltiplos aparelhos), é uma inovação mais simples e barata (que se refletiu nos custos de aparelhos mais baixos), atendeu de imediato a clientes sensíveis a preço (ofertas com aparelhos GSM tiveram maior apelo no público de massa, pré-pago) e melhorou consideravelmente o desempenho de forma a atender também as expectativas dos clientes tradicionais, no caso os pós-pagos de mais alto valor (CHRISTENSEN, 2000; PESSOA; MARTINS, 2007; ARMENIO NETO; GRAEML, 2010).

Frente ao contexto de mudança tecnológica e, baseando neste, aprofundou-se o entendimento da decisão estratégica de posicionamento da empresa, já que a teoria preconiza que algumas vezes a tecnologia pode não ter apelo aos clientes atuais da empresa e o posicionamento pode ser desenvolvido por meio de qualquer outra combinação de interações (PADGETT; MULVEY, 2007).

A estruturação do caso esmerou-se em oferecer um contexto assertivo do ambiente que antecedeu o evento-foco estudado, com dois intuitos: o primeiro, metodológico, de estabelecer um recorte para entendimento do sistema próprio dos entrevistados e estabelecer o foco e limites do estudo (LAKATOS; MARCONI, 2010; MARTINS, 2008); o segundo, prático, propiciar um panorama completo dos condicionantes para adoção (ou "herança") tecnológica das operadoras no momento de suas formações e das apostas estratégicas, nos níveis regulamentais e mercadológicos, que definiram as formas de atuação e por consequência, as posições de mercado.

Neste sentido, a investigação sobre a atividade de posicionamento foi tomada no conjunto do processo de marketing estratégico e relacionada com as atividades anteriores e posteriores à sua realização. Esta decisão se relaciona às práticas observadas na empresa, de que o marketing estratégico conecta a organização ao meio ambiente e coloca o marketing como 
uma responsabilidade do negócio como um todo, mais do que uma função especializada (CRAVENS; PIERCY, 2003).

Assim, a partir de modelos revistos na fundamentação teórica, estruturou-se uma análise estratégica da situação, no âmbito de clientes, companhia, colaboradores e concorrentes que forneceu bases para as decisões sobre as estratégias de segmentação e posicionamento. E a partir destas, as decisões sobre o composto de marketing, programa de marketing e/ou entrega de valor (CRAVENS; PIERCY, 2003; AMICCI, 2004; SILK, 2008).

Como apresentado antecipadamente no estudo de caso, os fatores condicionantes para a ocorrência do evento-foco foram sumarizados num mapa cognitivo, a partir da opinião unânime dos entrevistados. Pode-se afirmar que tais condicionantes relacionam-se fatalmente ao conjunto de fatores preconizados pela teoria no que tange à análise estratégica da situação. As questões de custo de aparelhos e de clonagem relacionam-se às esferas cliente e colaboradores; o aumento de importância dos atributos básicos da prestação de serviços relaciona-se diretamente aos clientes; a acentuação dos resultados declinantes do ponto de vista operacional se refere principalmente à agressividade da concorrência e, por fim, a movimentação interna na empresa, ocorrida por motivos, tanto do projeto de introdução da nova tecnologia GSM e, sobretudo, pelo efeito catalisador e de alavancagem exercido pelo novo comando, se relaciona diretamente às esferas de companhia e colaboradores.

Vale mencionar, brevemente, que a estratégia de segmentação não fora de fato amplamente destacada. A dinâmica de mercado oligopolista deste setor, dominado por quatro grandes operadoras, gera uma realidade de massa para as empresas, com bases de clientes imensas, praticamente do tamanho de países. Isso parece tornar o processo de segmentação muito mais prático do que estratégico, e acaba por estar fortemente atrelado às características de pagamento do serviço preferidas pelo cliente. Ou seja, a segmentação básica, ainda que relacionada ao marketing diferenciado, tem também características do marketing concentrado (MATTAR et al., 2009). Separa clientes individuais (pessoas físicas) de clientes corporativos (pessoas jurídicas) e entre os individuais, os distingue entre clientes premium - em que a grande maioria corresponde a clientes pós-pagos - e clientes massivos, em que a grande maioria são clientes pré-pagos.

No caso estudado, não se observou uma mudança de segmentação adotada pela empresa em conjunto à mudança de posicionamento. Mas o que o se observou foi uma mudança de postura empresarial em relação à estratégia de segmentação vigente. A mudança de estratégia 
trazida pelo novo comando reforçou e reconheceu a importância da valorização e reconhecimento das necessidades específicas de cada um dos "grandes grupos" de clientes, com propostas de valor específicas para cada um deles. Assim, pode-se dizer que se tratou de um caminho mais claro em direção à estratégia de marketing diferenciado e a variável de segmentação considerada para este aprofundamento foi o próprio comportamento do cliente (WEINSTEIN, 1995; HOOLEY; SAUNDERS, 1996).

Nesta linha, a mudança de posicionamento da empresa pode ser apreendida a partir da observação de três fenômenos. O primeiro foi a mudança para o mercado, evidenciada pela gestão dos "7 P's" de marketing de serviços e principalmente pela mudança da assinatura de marca, que revela a proposta e promessa da empresa para os clientes, "Vivo. Sinal de qualidade.”. O segundo e o terceiro foram as mudanças internas, estratégicas, que são identificadas pela mudança de postura corporativa, com a visão do novo comando, introduzindo o que se convencionou chamar "tripé da qualidade" e o que se derivou desta nova realidade, que foi o comprometimento interno com metas, através do denominado "Projeto Impulso".

Já se pode afirmar, a este ponto, que a possibilidade anteriormente apresentada com a questão de pesquisa, de que o posicionamento se alteraria com a introdução da inovação disruptiva, pode ser confirmada, como de fato mudou. Porém, o que se pôde perceber foi que a mudança de posicionamento não fora apenas unilateralmente motivada pela mudança de tecnologia e nem a mudança de posicionamento foi executada numa única dimensão.

O caso revelou que a decisão pela mudança de tecnologia, mais do que gerar uma nova proposta de valor (uma nova rede GSM), mobilizou a empresa internamente de forma considerável. A crença na tecnologia anterior - CDMA - na qual a empresa vinha apostando, e que reforçou publicitariamente muitas vezes, estava há muito tempo arraigada entre todos os colaboradores. A quebra de paradigma, com a decisão pela adoção da tecnologia GSM, somada à nova visão de comando, que ressaltava a importância da prestação de serviços de qualidade acima de tudo, promoveu um todo integrado, inseparável e indivisível que pode justificar a tecnologia como o motivador geral para a mudança de posicionamento.

Tal efeito já fora previsto por Tripsas (2003), em artigo que afirma que tecnologias emergentes fazem mais do que mudar as competências tecnológicas necessárias ao sucesso. 
geralmente focalizam-se em dominar a nova tecnologia em si e não conseguem compreender as implicações da tecnologia para essas outras áreas. Uma administração proativa dessas outras áreas, além do desenvolvimento de novas capacidades técnicas, é crucial à sobrevivência. Se esses fatores não forem radicalmente modificados, as empresas titulares terão uma chance muito melhor de obter sucesso em uma mudança tecnológica fazendo investimentos contínuos nos ativos não-técnicos [...] A mudança tecnológica, portanto, deve ser somente um dos fatores que formam a estratégia geral de comercialização (TRIPSAS, 2003, p. 162).

Em linha com o que defende Tripsas (2003), percebeu-se esse "poder" de uma tecnologia emergente em mudar as competências internas da empresa, muito além da tecnologia. $\mathrm{Na}$ pesquisa empírica observou-se repetidamente como os entrevistados referem-se a esse período da empresa como um "momento de virada", um momento decisivo e que precisava acontecer. Relataram também, unanimemente, o momento da empresa como de grande motivação e satisfação interna, e em que a capacidade em mudar e atender as expectativas para os clientes, tanto internos como externos, tangibilizava a credibilidade de uma empresa ágil, inovadora e pronta para as mudanças, e competitiva num mercado que se tornava cada vez mais agressivo.

Portanto, nos faz parecer que a forma como a empresa encarou a mudança de tecnologia, a preparou para as demais mudanças que se fariam necessárias para o momento de mudança geral da empresa, despertando e trabalhando desde as competências até os ativos complementares necessários para tal.

Esta mesma preocupação na forma como se encara a inovação é expressada por Knox (2002), quando afirma que hoje a inovação precisa ser mais amplamente definida e entendida pelos gestores, considerando-se que os ativos e capacidades de uma organização podem ser gerenciados para criar valor para o cliente num nível corporativo, além do âmbito das receitas, custos e retornos diretamente associados aos produtos e serviços.

Alguns dos entrevistados frisaram que o sucesso fora resultado de um processo integrado entre estratégia e marca. Mencionam que o projeto de marca, que redefiniu a identidade de marca - seus valores, seus atributos, sua personalidade e suas expressões (KAPFERER, 2003; AAKER, 2008), com alcance para os públicos interno, em primeiro lugar, e externo, num segundo momento com todas as ações de comunicação ao público e imprensa, foram cuidadosamente alinhados a todo o processo estratégico da empresa ("Projeto Impulso"), direcionando adequadamente todos os esforços num sentido único, de construção da posição desejada (KHAUAJA; MATTAR, 2006).

Esta combinação entre a estratégia macro da empresa e a identidade pretendida da marca gerou uma forte combinação que na teoria se observou como a integração entre o 
posicionamento da marca ou psicológico (AAKER; JOACHIMSTHALER, 2007; DI MINGO, 1988) e o posicionamento competitivo ou estratégico (ALCANIZ; LÓPEZ, 2000; HOOLEY, 1996).

As diretrizes definidas pela empresa para a definição do novo posicionamento, desdobradas a partir da definição da estratégia geral da empresa, transpareceram para o mercado o novo discurso de comprometimento, ao mesmo tempo, comprometendo a empresa como um todo.

Reconhecendo-se o potencial criativo, a nova assinatura de posicionamento definida, "Vivo. Sinal de qualidade", pretendeu e pareceu significar, obviamente, a continuidade na qualidade de ligação com a introdução da tecnologia GSM, pela qual a marca já era reconhecida. Ao mesmo tempo, o apelo gramatical e sintático da construção permitia o duplo sentido com o uso corriqueiro da expressão "Sinal de", largamente utilizado no português, para indicar que a marca Vivo seria "sinal de qualidade" em sua totalidade de interações (qualidade no atendimento, no portfólio de aparelhos, nos planos, nas promoções, entre outros).

Assim, no que diz respeito ao posicionamento de marca (psicológico) trabalhado, em linha com as diretrizes de posicionamento estabelecidas, a empresa optou por focar mais no cliente que na própria empresa ("customer centric"), mais nos serviços que na tecnologia, mais nos benefícios que nos atributos. Portanto, entende-se a opção da empresa de, nas diversas expressões do composto de marketing - principalmente promoção, produto, praça, instalações (BOOMS; BITNER, 1981; KOTLER; KELLER, 2006), não destacar ou não priorizar a mensagem referente à introdução da tecnologia GSM de forma explícita. Foram privilegiados na comunicação em geral os serviços que decorreram da introdução dessa nova tecnologia e os benefícios advindos do uso destes serviços na vida das pessoas; muito diferentemente da postura e tom de comunicação anteriores com o CDMA, em que a tecnologia tinha ampla visibilidade e era enaltecida como vantagem competitiva no discurso.

Este efeito pôde ser observado no estudo de caso, a partir da análise cruzada das pesquisas disponibilizadas pela empresa. $\mathrm{Na}$ opinião dos consumidores, a introdução da tecnologia GSM não movimentou de forma significativa a imagem da operadora, nem positiva nem negativamente. Porém, ao se avaliar a imagem geral de marca, formada por todos os atributos, observou-se um crescimento das associações aos atributos desejados.

Cabe ainda mencionar, que a estratégia de comunicação em fases, que a empresa determinou para o lançamento do novo posicionamento caracterizou-se, segundo a teoria, como uma 
conjunção de um modelo inicialmente racional, enfatizando atributos explícitos dirigidos ao lado racional da mente do consumidor - nas fases de "prestação de contas" e de "ofertas" com um modelo emocional, enfatizando de forma implícita os benefícios advindos do uso do produto - na fase de lançamento (MATTAR et al., 2009). Além disso, é possível observar que a comunicação tratou de promover um benefício único, a qualidade, como o mais distintivo e importante do serviço ofertado (unique selling proposition).

Por fim, com a intenção de cumprir com a totalidade dos objetivos específicos propostos para o trabalho, reitera-se a investigação realizada de como o composto de marketing da empresa foi gerido em sua totalidade, nos 7 P's de marketing de serviços (HOFFMAN et al., 2009), refletindo a mudança de posicionamento estratégico e de marca.

Como antecipado no capítulo de estudo de caso, os impactos motivados pela mudança de posicionamento foram considerados mais intensos nos P's de produto (serviços e aparelhos), de promoção (comunicação e vendas) e pessoas (colaboradores e atendentes em geral). Foram considerados medianos nos P's de preço (planos, recargas e promoções) e de processos (atendimento e sistemas) e atribui-se o nível baixo de impacto para os P's de praça (distribuição e logística) e de physical surroundings (instalações e lojas).

Não se pretende rediscutir em profundidade as ações tomadas pela empresa em cada um dos fatores do composto de marketing. Porém vale ressaltar que a observação dos maiores impactos, em produtos, promoção e principalmente em pessoas, revela o caráter distintivo do marketing de serviços, em que o fator humano é decisivo. Desde o "encontro de serviços" ou "hora da verdade" (LOVELOCK; WRIGHT, 2001; GRÖNROSS, 1995) - em que a interação entre o cliente e os representantes da empresa acontece - até a consideração do colaborador interno como fator chave de sucesso para a construção de todas as etapas que levam até a ocorrência desse encontro com o cliente (incluindo o desenvolvimento de serviços e de comunicação atrativa, persuasiva e de credibilidade).

Quanto aos resultados que a empresa obteve e que se puderam ter acesso, revelam pontos que se interligam aos pressupostos conceituais assumidos para o trabalho, de que a orientação para o mercado assumida reverteu num desempenho positivo e aumento de competitividade futura da empresa (NARVER; SLATER, 1990).

Cabe ainda repetir que os resultados observados quanto à introdução da tecnologia GSM reforçaram a dinâmica preconizada pela teoria da inovação disruptiva, de que o desempenho é 
inicialmente ruim, mas que no curto ou médio prazo alcançam um nível pleno de competitividade (CHRISTENSEN, 2000).

Os resultados operacionais demonstraram a capacidade da empresa em deter e suavizar a tendência declinante de negócios. Os resultados financeiros, representados pela evolução da margem EBITDA, evidenciam a melhoria progressiva de capacidade da empresa nos anos sucessivos e atestam a contribuição da tecnologia GSM para o controle e redução dos custos, também. Sendo que ambos os fatos foram considerados críticos como condicionantes para a ocorrência do evento-foco.

Por fim, a expectativa futura, representativa da sobrevivência e competitividade da empresa pode ser afinal atestada pela atual situação da empresa, fato relevantemente mencionado pela maioria dos entrevistados, a qual mantém, na perspectiva operacional, a liderança de mercado e na perspectiva de marca, continua a deter a posição de marca mais valiosa do mercado de telecomunicações, com o valor de $\mathrm{R}$ \$ 8,8 bilhões, segundo o ranking 2012 da consultoria Brand Finance.

\subsection{Limitações do estudo}

Ao final deste trabalho, faz-se uma breve reflexão sobre suas limitações, que naturalmente se relacionam ao escopo previsto, bem como com a estratégia de pesquisa escolhida.

Observou-se que a relação entre os construtos de tecnologia/inovação e posicionamento, propriamente no ambiente de serviços, que é o escopo teórico abordado neste trabalho, tem ainda pouca difusão nos estudos acadêmicos, mais focados atualmente no construto de satisfação.

A realização do estudo de caso, por suas características apresenta diversas limitações, mas por outro lado, dá origem a oportunidades para estudos futuros. A principal limitação do estudo se refere à especificidade do caso analisado, em setor específico, definido dentro de critérios préestabelecidos, não sendo possível a generalização dos resultados para outros setores/categorias. Esta limitação, no entanto, está em conformidade com a proposta de caráter exploratório do trabalho.

Pelo fato de o fenômeno estudado estar localizado no tempo passado, a coleta de dados constituiu-se numa tarefa intrincada, tanto nas entrevistas em profundidade, exigindo dos entrevistados um esforço de memória adicional para a concatenação de fatos e datas, como no 
levantamento de dados secundários e internos da organização, demandando sucessivas buscas em arquivos e materiais antigos da empresa. Porém, esta foi forma possível encontrada para se triangularem dados e informações de forma a aumentar a validade do estudo.

Há que se destacar ainda a complexidade de análise do processo estratégico de uma empresa de grande porte, como a avaliada no caso, sendo necessário estabelecer um recorte mais superficial para entendimento dos processos de forma geral. Uma ampliação de escopo do estudo poderia se ocupar de aprofundar a visão e entendimento das ações e projetos desenvolvidos, porém neste estudo não foi possível o resgate de informações históricas até este nível de detalhe.

Por fim, vale ressaltar que o campo de estudo do posicionamento e sua aplicação na estratégia de marketing de serviços é amplo o suficiente para comportar inúmeros estudos e oferece aos pesquisadores inúmeros desafios a considerar.

\subsection{Recomendações para estudos futuros}

Considera-se que o trabalho cumpriu com sua missão de adicionar conhecimento ao campo de estudo do posicionamento de marcas de serviços e fornece alternativas para os interessados em desenvolver estudos nesta linha de pesquisa.

Estudos futuros poderão vir a pesquisar as interações entre os construtos de tecnologia/inovação e posicionamento em outros setores de serviços da economia brasileira, bem como estes construtos estão relacionados mediados por outros contextos estratégicos não necessariamente orientados para o mercado (por exemplo, terceiro setor ou setores do governo).

É também uma possibilidade a replicação deste estudo para avaliação desta mesma situação peculiar em mercados de telecomunicações do Brasil e de outros países, frente às novas tecnologias de comunicação que vêm surgindo (por exemplo, tecnologias $3 \mathrm{G}$ e 4G). Estudos que sugiram uma visão complementar de como empresas de serviços concorrentes reagem frente à introdução de uma inovação disruptiva por uma determinada empresa, também poderão vir a trazer importantes contribuições.

No limite, novos estudos neste campo agregarão para o entendimento da complexidade da gestão do composto de marketing de serviços e para um contínuo esclarecimento enquanto às formas de superação dos problemas advindos das características distintivas de serviços. 
De forma geral, a contribuição acadêmica e gerencial do estudo está na compreensão da extensão das implicações que podem ocorrer na atuação de marketing mediante a introdução de uma forma específica de inovação. De forma análoga, estudos semelhantes poderão vir a investigar e compreender níveis diversos de impacto nas ações de marketing, motivadas pela introdução de outros tipos de inovações, em diferentes níveis de disrupção. 


\section{REFERÊNCIAS}

AAKER, D. A. Marcas - Brand Equity: gerenciando o valor da marca. São Paulo: Elsevier Editora, 1996.

. Construindo marcas fortes. Porto Alegre: Bookman, 2008.

; JOACHIMSTHALER, E. Como construir marcas líderes. Porto Alegre: Bookman, 2007.

ADNER, R.; ZEMSKY, P. Disruptive Technologies and the Emergence of Competition. RAND Journal of Economics. [S.1.], v. 36, n. 2, p. 229-254, summer 2005.

ALCANIZ, J. E. B.; LÓPEZ, N. V. Estrategia de empresa y posicionamiento de producto en la industria del automóvil: un análisis comparado. Economia Industrial. [S.1.], n. 332, p. 2942, 2000.

ALRECK, P. L.; SETTLE, R. B. The Survey Research Handbook. Irwin, 1995.

AMICCI, F. L. Software sob encomenda: um estudo exploratório de segmentação e posicionamento no mercado empresarial. São Paulo, 2004. Dissertação (Mestrado em Administração) - Programa de Pós-Graduação em Administração, Faculdade de Economia, Administração e Contabilidade da Universidade de São Paulo.

ANDER-EGG, E. Introducción a las técnicas de investigación social: para trabajadores sociales. 7. ed. Buenos Aires: Humanitas, 1978.

ARMENIO NETO, J.; GRAEML, A. R. VoIP: Inovação Disruptiva no Mercado de Telefonia Corporativa. Revista Alcance. [Online], v. 17, n. 1, p. 07-21, 2010.

BATEY, M. O significado da marca: como as marcas ganham vida na mente dos consumidores. Rio de Janeiro: Best Business, 2010.

BERRY, L. L. et al. Managing the total customer experience. MIT Sloan Management Review. [S.1.], v.43, n. 3, p.85-88, 2002.

BERTHON, P. et al. Viewing Brands in Multiple Dimensions. MIT Sloan Management Review. Cambridge, MA, v. 48, n. 2, p. 37-43, 2007.

BITNER, M. J. Evaluating Service Encounters: The Effects of Physical Surroundings and Employee Responses. Journal of Marketing. [S.1.], v. 54, p. 69-82, apr. 1990. 
BOOMS, B. H.; BITNER, M. J. Marketing Strategies and Organization Structures for Service Firms. In: Marketing of Services. DONNELLY, J. H. (ed.); WILLIAM, G. R. (ed.). Chicago: American Marketing Association, p. 47-52, 1981.

BRESSAN, F. O método do estudo de caso. Administração On Line Fecap. São Paulo, v. 1, n. $1,2000$.

CAMPOMAR, M. C. Do uso de "estudo de caso" em pesquisas para dissertações e teses em administração. Revista de Administração. São Paulo, v. 26, n. 3, p. 95-97, jul. / set. 1991.

; IKEDA, A. A. O planejamento de marketing e a confecção de planos. São Paulo: Saraiva, 2006.

CASTELLS, M. A sociedade em rede. São Paulo: Paz e Terra, 1999.

CHARITOU, C. D.; MARKIDES, C. C. Responses to Disruptive Strategic Innovations. MIT Sloan Management Review. [S.1.], v. 44, n. 2, p. 55-63, winter 2003.

CHRISTENSEN, C. M. O crescimento pela inovação: como crescer de forma sustentada e reinventar o sucesso. Rio de Janeiro: Elsevier, 2003.

The innovator's dilemma. New York: Harper Collins, 2000.

COLLIS, J.; HUSSEY, R. Pesquisa em administração: um guia prático para alunos de graduação e pós-graduação. 2. ed. Porto Alegre: Bookman, 2005.

CRAVENS, D; PIERCY, N. Strategic Marketing. 7th ed. New York: McGraw Hill, 2003.

DA ROCHA, A.; FERREIRA DA SILVA, J. Marketing de serviços: retrospectiva e tendências. Rev. Adm. Empres. [Online], v. 46, n. 4, p. 1-9, 2006.

DI MINGO, E. The fine art of positioning. The Journal of Business Strategy. Boston, v. 9, n. 2, p. 34-38, mar. / apr. 1988.

DODOUROVA, M. Industry dynamics and strategic positioning in the wireless telecommunications industry: The case of Vodafone Group plc. Management Decision. London, UK, v. 41, n. 9, p. 859-870, 2003.

EISENHARDT, K. M. Building Theories from Case Study Research. Academy of Management Review. [S.1.], v. 14, n. 4, p. 532-550, 1989.

FENNELL, G. Consumer's perceptions product-use situation. Journal of Marketing. New York, v. 42, n. 2, p. 38-47, apr. 1978. 
FERRARESI, A. A. Gestão do conhecimento, orientação para o mercado, inovatividade e resultados organizacionais: um estudo em empresas instaladas no Brasil. São Paulo, 2010. Tese (Doutorado em Administração) - Programa de Pós-Graduação em Administração, Faculdade de Economia, Administração e Contabilidade da Universidade de São Paulo.

FRANSMAN, M. Evolution of the Telecommunications Industry into the Internet Age. Communications \& Strategies. [S.1.], n. 43, p. 57-113, 3rd quarter 2001.

FRONTINI, M. A. B. Convergência digital e a telefonia móvel: implicações à gestão estratégica e à inovação. São Paulo, 2008. Tese (Doutorado em Engenharia). Escola Politécnica, Universidade de São Paulo.

GIL, A. C. Métodos e técnicas de pesquisa social. São Paulo: Atlas, 2006.

GOVINDARAJAN, V.; KOPALLE, K. K. The Usefulness of Measuring Disruptiveness of Innovations Ex Post in Making Ex Ante Predictions. Journal of Product Innovation Management. [S.1.], v. 23. n. 5. p. 12-18, 2006.

GRÖNROOS; C. Marketing, gerenciamento e serviços: a competição por serviços na hora da verdade. Rio de Janeiro: Campus, 1995.

GUEDES, L. F. A.; VASCONCELLOS, L. Uma proposta de modelo preditivo para o crescimento da telefonia celular no Brasil. Future Studies Research Journal: Trends and Strategy. São Paulo, v. 1, n. 1, jan. / jun. 2009.

HOFFMAN, K. D et al. Princípios de marketing de serviços: conceitos, estratégias e casos. São Paulo: Cengage Learning, 2009.

; TURLEY, L. W. Atmospherics, service encounters and consumer decision making: An integrative perspective. Journal of Marketing Theory and Practice. [S.1.], n. 10, p. 3347, summer 2002.

HOOLEY, G. J.; SAUNDERS, J. Posicionamento Competitivo. São Paulo: Makron Books do Brasil, 1996.

et al. Market-focused Resources, Competitive Positioning and Firm Performance. Journal of Marketing Management. [S.1.], v. 17, n. 5-6, p. 503-520, 2001.

JURISIC, B.; AZEVEDO, A. Building customer-brand relationships in the mobile communications market: The role of brand tribalism and brand reputation. Journal of Brand Management, London, UK, v. 18, n. 4-5, p. 349-366, 2011.

KAPFERER, J. N. Strategic Brand Management: New approaches to creating and evaluating brand equity. New York: The Free Press, 1994.

As marcas, capital da empresa: criar e desenvolver marcas fortes. 3. ed. Porto Alegre: Bookman, 2003. 
KAPLAN, R. S.; NORTON, D. P. A Estratégia em Ação: Balanced Scorecard. 5. ed. Rio de Janeiro: Campus, 1997.

KELLER, K. L. Managing brands for the long run: Brand reinforcement and revitalization strategies. California management review. Berkeley, v. 41, n. 3, p. 102-124, 1999.

KHAN, M.; KHAN, M. A. How technological innovations extend services outreach to customers. International Journal of Contemporary Hospitality Management. Bradford, UK, v. 21, n. 5, p. 509-522, 2009.

KHAUAJA, D.; MATTAR, F. N. Fatores de marketing na construção de marcas sólidas: estudo exploratório com marcas brasileiras. REGE-USP. São Paulo, v. 12, n. 4, p. 25-38, out. / dez. 2006.

KNOX, S. The boardroom agenda: Developing the innovative organisation. Corporate Governance. Bradford, UK, v. 2, n. 1, p. 27-36, 2002.

KOTLER P.; KELlER, K. L. Administração de Marketing. São Paulo: Pearson Prentice Hall, 2006.

; BES, F. T. A Bíblia da Inovação: princípios fundamentais para levar a cultura da inovação contínua às organizações. São Paulo: Leya, 2011.

LAMBIN, J. J. Marketing Estratégico. Madrid: McGraw Hill, 1995.

LANGEARD, E. et al. Services marketing: new insights from consumer and managers. Marketing Science Institute. Cambridge, MA, p. 81-104, 1981.

LAKATOS, E. M.; MARCONI, M. A. Fundamentos de metodologia científica. 7. ed. São Paulo: Atlas, 2010.

LAS CASAS, A. L. Marketing de serviços. 2. ed. São Paulo: Atlas, 2000.

LOVELOCK, C.; WRIGHT, L. Serviços: Marketing e Gestão. São Paulo: Saraiva, 2001.

MALHOTRA, N. K. Pesquisa de marketing: uma orientação aplicada. 3. ed. Porto Alegre: Bookman, 2001.

MARCONI, M. A.; LAKATOS, E. M. Fundamentos de metodologia científica. 5. ed. São Paulo: Atlas, 2003.

MARTINS, G. A. Sobre Confiabilidade e Validade. RBGN. São Paulo, v. 8, n. 20, p. 1-12, jan. / abr. 2006.

Estudo de caso: uma estratégia de pesquisa. São Paulo: Atlas, 2008. 
; THEÓPHILO, C. R. Metodologia da investigação científica para ciências sociais aplicadas. São Paulo: Atlas, 2007.

MATTAR, F. N. (Org.) et al. Gestão de produtos, serviços, marcas e mercados: estratégias e ações para alcançar e manter-se "Top of Market". São Paulo: Atlas, 2009.

MCCRACKEN, G. Cultura e consumo: novas abordagens ao caráter simbólico dos bens e das atividades de consumo. Rio de Janeiro: Mauad, 2003.

MCKENNA, R. Estratégias de marketing em tempos de crise. Rio de Janeiro: Campus, 1989.

MONTE, E. F.; Posicionamento: da propaganda ao nível estratégico. In: Cadernos de Pesquisas em Administração. São Paulo, v. 1, n. 7, 2. trim. 1998.

NARVER, J. C.; SLATER, S. F. The effect of a market orientation on business profitability. Journal of Marketing. [S.1.], v. 54, n. 4, p. 20-35, 1990.

NEVES, M. S. O setor de telecomunicações. In: SÃO PAULO, E. M.; KALACHE FILHO, J. (Org.). BNDES 50 Anos: Histórias Setoriais, v. 1, p. 297-319. São Paulo: DBA Artes Gráficas, 2002.

OLIVEIRA, B. C. Revisitando o posicionamento em marketing. Revista de Gestão USP. São Paulo, v. 14, n. 1, p. 41-52, jan. / mar. 2007.

; CAMPOMAR, M. C. O reposicionamento em marketing como elemento de competitividade. XI SEMEAD - Empreendedorismo em Organizações. São Paulo: FEA, 2008.

; ___ ; LUIS, C. Posicionamento estratégico em turismo, o caso Sabre Brasil. Revista Tur. Anál. São Paulo, v. 19, n. 1, p. 64-84, 2008.

PADGETT, D.; MULVEY, M.S. Differentiation Via Technology: Strategic Positioning of Services Following the Introduction of Disruptive Technology. Journal of Retailing, Greenwich, US, v. 83, n. 4, p. 375-391, 2007.

PALMER, A.; COLE, C. Services marketing: principles and practices. New Jersey: PrenticeHall, 1995.

PARASURAMAN, A. et al. A conceptual model of service quality and its implications for future research. Journal of Marketing. USA, v. 49, n. 4, p. 41-50, fall 1985.

PEREIRA, M. M.; GUEDES, L. G. R. Perspectivas das comunicações móveis no Brasil. Revista Digital Online. [S.1.], v. 2, p. 25-41, jan. 2004. 
PESSOA, E; MARTINS, M. Revisitando a teoria do ciclo do produto. Rev. Econ. Contemp. Rio de Janeiro, v. 11, n. 2, p. 307-329, 2007.

PIRES, J. C. L. A reestruturação do setor de telecomunicações no Brasil. Revista do BNDES. [S.l.], n. 11, 1999.

QUINTELlA, R. H.; COSTA; M. A. Costa. O setor de telefonia móvel do Brasil após o SMP: as estratégias das operadoras e a convergência fixa-móvel. RAP. Rio de Janeiro, v. 43, n. 1, p. 123-50, jan. / fev. 2009.

RIES, A.; TROUT, J. Posicionamento: a batalha pela sua mente. São Paulo: Pioneira Thomson Learning, 2007.

ROESCH, S. M. A. Projetos de Estágio e de Pesquisa em Administração. 2. ed. São Paulo: Atlas, 1999.

SADLER, T. D. et al. Socioscience and ethics in science classrooms: teacher perspectives and strategies. Journal of Research in Science Teaching. [S.1.], v. 43, p. 353-376, 2006.

SAMPIERI, R. H. et al. Metodologia de pesquisa. 3. ed. São Paulo: McGraw-Hill, 2006.

SANTA RITA, L. P.; SBRAGIA; R. Inovação em serviços como condicionante da competitividade da telefonia móvel. Rev. Cent. Ciênc. Admin. Fortaleza, v. 12, n. 1, p. 8397, ago. 2006.

SATO, S. K. As expressões da mobilidade na comunicação das marcas de telefonia celular no Brasil. São Paulo, 2010. Dissertação (Mestrado em Ciências da Comunicação). Escola de Comunicação e Artes, Universidade de São Paulo.

SBRAGIA, R. et al. Panorama Setorial em Telecomunicações. In: SBRAGIA, R.; GALINA, S. V. R. (org.). Gestão da Inovação no Setor de Telecomunicações. São Paulo: PGT/USP, p. 3-37, 2004.

SERRALVO, F. A.; FURRIER, M. T. Fundamentos do posicionamento de marcas: uma revisão teórica. In: SEMINÁRIOS EM ADMINISTRAÇÃO - SEMEAD, 7., 2004. Anais do VII Semead. São Paulo: FEA-USP, 2004.

; Reposicionamento de marcas: um estudo de casos brasileiros. Revista Brasileira de Gestão de Negócios. São Paulo, v.10, p. 1-16, 2008.

SETH, N. et al. Service quality models: a review. International Journal of Quality and Reliability Management. [S.1.], v. 22, n. 9, p. 913-949, 2005.

SIFFERT FILHO, N. e SILVA, C. S. As Grandes Empresas nos anos 90: Respostas Estratégicas a um cenário de mudanças. Rio de Janeiro: BNDES, 1999. 
SILK, A. J. O que é Marketing. Porto Alegre: Bookman, 2008.

Telefonia Celular Móvel. Informe Infra-estrutura. Revista do BNDES. [S.1.] n. 15, out. 1997.

TELLES, R. Posicionamento e reposicionamento de marca: uma perspectiva estratégica e operacional dos desafios e riscos. São Paulo, 2010. Tese (Doutorado em Administração). Faculdade de Economia, Administração e Contabilidade da Universidade de São Paulo.

TOLEDO, G. L.; HEMZO, M. A. O processo de posicionamento e o marketing estratégico. In: ENCONTRO ANUAL DA ASSOCIAÇÃO NACIONAL DE PROGRAMAS DE PÓSGRADUAÇÃO EM ADMINISTRAÇÃO - ENANPAD, 15, 1991, Belo Horizonte. Anais do XV ENANPAD. Belo Horizonte: ANPAD, 1991.

et al. O composto de marketing no contexto estratégico da internet. Revista de Administração Mackenzie. São Paulo, v.3, n.1, p. 33-78, 2002.

TRIPSAS, M. Comercializando tecnologias emergentes por meio de ativos complementares. In: DAY, G. S. et al. Gestão de tecnologias emergentes: a visão da Wharton School. Porto Alegre: Bookman, 2003.

TURATTI, L. F. A. Extensões de marca: um estudo de caso. São Paulo, 2005. Dissertação (Mestrado em Administração) - Programa de Pós-Graduação em Administração, Faculdade de Economia, Administração e Contabilidade da Universidade de São Paulo.

VALDÉS, J. A. Marketing estratégico e estratégia competitiva de empresas turísticas: um estudo de caso da cadeia hoteleira Sol Meliá. São Paulo, 2003. Tese (Doutorado em Administração) - Programa de Pós-Graduação em Administração, Faculdade de Economia, Administração e Contabilidade da Universidade de São Paulo.

WEINSTEIN, A. Segmentação de mercado. São Paulo: Atlas, 1995.

WIND. Y. Issues and Advances in Segmentation Research. Journal of Marketing Research. [S.1.], v. 15, n. 3, p. 317-337, aug. 1978.

YIN, R. K. Estudo de caso: planejamento e métodos. Porto Alegre: Bookman, 2010.

ZEITHAML, V. A.; BITNER, M. J. Marketing de Serviços: a empresa com foco no cliente. Porto Alegre: Bookman, 2003.

ZOLFAGHARIAN, M. An exploratory investigation of the effects of co-production and coconsumption on the characteristics and adoption of service innovations: the customer's perspective. USA, 2007. Tese (Doutorado em Filosofia) - University of North Texas. 


\section{WEBGRAFIA}

AMERICAN MARKETING ASSOCIATION - AMA. AMA Dictionary of basic marketing definition. Disponível em: <http://www.marketingpower.com/_layouts/Dictionary.aspx? dLetter=B $>$. Acessado em set. 2012.

FUSCO, C.; BRAUN, D. Roberto Lima é o novo presidente da Vivo. Mobilidade - IDG NOW!. 2005. Disponível em: <http://idgnow.uol.com.br/mobilidade/2005/05/20 /idgnoticia.2006-03-12.2445130678/>. Acessado em 20/04/2013.

GUIMARÃES, C. Oi lança campanha com ovelha Dolly. Exame.com. 2002. Disponível em: $<$ http://exame.abril.com.br/marketing/noticias/oi-lanca-campanha-com-ovelha-dolly-m00611 44>. Acessado em 29/04/2013.

Portal ANATEL. Disponível em: <http://www.anatel.gov.br>. Acessado em 05/08/2012.

Site ARQUIVO DA PROPAGANDA. Disponível em: <http://www.arquivo.com.br>. Acessado em 21/07/2012.

Site OPERADORA VIVO. Disponível em http://www.vivo.com.br>. Acessado em 20/07/2012.

Site SINDITELEBRASIL. Disponível em: <http://www.sinditelebrasil.org.br > Acessado em 10/08/2012.

Site TELECO - INTELIGÊNCIA EM TELECOMUNICAÇÕES. Disponível em: <http://www.teleco.com.br>. Acessado em 10/08/2012. 


\section{APÊNDICE 1 - PROTOCOLO DE PESQUISA}

Para esta pesquisa, de forma objetiva, foi seguido o seguinte protocolo:

1. Revisão da literatura, com compreensão dos conceitos precedentes à questão-problema de pesquisa;

2. Identificação e aprofundamento dos tópicos relevantes relacionadas aos construtos posicionamento e composto de marketing;

3. Justificativa e definições em relação ao método de pesquisa adotado para estudo de caso único e peculiar na empresa Vivo, com extensiva descrição do posicionamento antes e depois da introdução da inovação disruptiva;

4. Realização de pesquisa documental, com levantamento de dados secundários na empresa e informações adicionais coletadas posteriormente com os entrevistados;

5. Identificação de potenciais entrevistados na empresa de acordo com o evento peculiar selecionado para estudo;

6. Convite e marcação das entrevistas em profundidade;

7. Realização da entrevista em profundidade, com perguntas abertas (modelo de roteiro apresentado a seguir);

8. Transcrição e codificação das entrevistas gravadas;

9. Análise dos dados coletados;

10. Redação do texto final. 


\section{APÊNDICE 2 - VISÃO GERAL DO PROJETO}

\section{Tema e objetivos}

Esta pesquisa é parte integrante do programa de pós-graduação em administração da FEAUSP, como requisito para obtenção do titulo de Mestre em Administração.

O tema central é a relação entre o posicionamento de marketing e a introdução de inovações disruptivas.

Estuda-se como este tema se desenvolve especificamente em uma empresa de serviços, do setor de telecomunicações brasileiro.

A literatura revista envolveu temas subjacentes à questão-problema tais como estratégia de marketing, marketing de serviços, segmentação, gestão de marcas, identidade e imagem de marcas, posicionamento, composto de marketing, inovações disruptivas, conceituações de tecnologias de conexão móvel como o CDMA e o GSM, além de um panorama do setor de telecomunicações do Brasil.

\section{Procedimentos de campo}

\section{- Definições metodológicas:}

Execução de pesquisa qualitativa de caráter exploratório e uso do estudo de caso como estratégia. Enfoque histórico no levantamento dos dados e abordagem dos entrevistados para remontagem do evento-foco em estudo.

\section{- Empresa estudada:}

A empresa em questão a ser estudada é a Vivo, operadora de telecomunicações móveis brasileira. A empresa foi formada a partir de uma joint venture em abril / 2003, após a fusão de 7 grandes empresas de telecomunicações móveis atuantes em diversas regiões do Brasil à época.

A unidade de análise para o caso são os executivos da empresa diretamente envolvidos no processo relacionado com o evento-foco do estudo: a implementação da nova tecnologia 
GSM na operação da empresa, de forma concomitante à mudança de posicionamento de marca, ocorridos no período entre os anos de 2006 e 2007.

Os principais critérios considerados para a seleção dos executivos para a etapa de entrevistas em profundidade foram:

- Atuação na empresa Vivo como executivo à época do evento-foco estudado;

- Envolvimento com os processos de execução e decisão concernentes ao evento-foco, desde o nível mais estratégico de definição da estratégia até as decisões relacionadas ao composto de marketing;

- Resgate do organograma da empresa à época do evento-foco para identificação dos executivos atuantes e respectivas funções;

- Foram privilegiados os executivos com atuação relacionada à gestão do composto de marketing de forma ampliada, considerando a estrutura organizacional da empresa à época.

- Não foi considerado um critério obrigatório para seleção a permanência do executivo na empresa nos dias atuais.

O processo de agendamento de entrevistas em profundidade foi realizado com um convite prévio, enviado por meio de correio eletrônico e posterior agendamento de entrevistas. As entrevistas foram realizadas de forma pessoal e individual, em sua maior parte no escritório da empresa Vivo e, no caso de executivos que estão em outras empresas atualmente, nos escritórios das empresas que atuam. Não houve restrições de nenhum tipo ao longo da realização do processo de entrevistas.

As entrevistas foram conduzidas pelo próprio autor deste trabalho, tiveram duração média de uma hora cada e foram registradas sonoramente por meio de um aparelho Apple iPad, além de anotações realizadas pelo autor. 
Como resultado deste processo, foram realizadas entrevistas com os seguintes executivos da empresa:

\section{Quadro 26 - Perfis dos executivos entrevistados}

\begin{tabular}{|l|l|c|}
\hline \multicolumn{1}{|c|}{ Executivo } & \multicolumn{1}{|c|}{ Perfil } & $\begin{array}{c}\text { Data da } \\
\text { entrevista }\end{array}$ \\
\hline Daniel Cardoso & $\begin{array}{l}\text { Diretor de Estratégia e Avaliação de Performance, entre 2007 e 2009. } \\
\text { Posteriormente Diretor Executivo de Marketing e, atualmente, Diretor Executivo de } \\
\text { Estratégia e Novos Negócios. }\end{array}$ & $07 /$ mai/13 \\
\hline Giseli Passarini & Gerente de Inteligência de Mercado e Consumidor, desde 2003 aos dias atuais. & $23 /$ abr/13 \\
\hline Hugo Janeba & $\begin{array}{l}\text { Diretor de Imagem e Comunicação, entre 2003 e 2008. } \\
\text { Posteriormente Vice-presidente Executivo de Marketing e Inovação, entre 2008 e 2011. }\end{array}$ & $23 /$ abr/13 \\
\hline Joyce Paiva & Diretora de Marketing Operacional e, posteriormente, Gerente de Trade Marketing. & $09 /$ mai/13 \\
\hline Leonardo Contrucci & $\begin{array}{l}\text { Gerente de Marketing Pessoa Física, entre 2005 e 2012. } \\
\text { Posteriormente Diretor de Marketing Segmento Pré-pago, até aos dias atuais. }\end{array}$ & $24 / \mathrm{abr} / 13$ \\
\hline Silvio Sato & Gerente de Estratégia de Comunicação e Branding, entre 2005 e 2011. & $26 /$ abr/13 \\
\hline
\end{tabular}

Fonte: Criado pelo autor 


\section{APÊNDICE 3 - ROTEIRO DE ENTREVISTA EM PROFUNDIDADE}

A seguir apresenta-se o roteiro das questões abertas para as entrevistas em profundidade. $\mathrm{O}$ roteiro está divido em três partes:

- Parte 1: de forma resumida, traz as informações pessoais do executivo entrevistado e sua posição e área atual e também à época do evento-foco, para situar sua contribuição no conjunto dos achados da pesquisa;

- Parte 2: é composta por questões gerais, comuns a todos os profissionais entrevistados, mais relacionadas à atuação da empresa num contexto mais amplo à época do evento-foco;

- Parte 3: é uma parte mais breve e traz questões mais específicas, enfocando processos e atividades específicos da área de atuação do executivo. 
Roteiro de entrevista em profundidade

Data $\longrightarrow$ Hora de início $\square$ Hora de término

Parte 1: Informações pessoais

1.1 Nome

1.3 Cargo atual

1.5 Cargo em 2006

1.2 Está hoje na empresa? Sim ( ) Não ( )

1.4 Área atual

1.6 Área em 2006

Parte 2: Sobre as mudanças na empresa, no período 2006-2007

2.1 Como era a empresa na época em que atuava com a tecnologia CDMA? Quais eram as fortalezas, dificuldades e desafios?

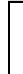

2.2 Qual era a sua opinião sobre a atuação com a tecnologia GSM à época? O que sabia?

2.3 Como você observava a atuação da empresa com o CDMA e da concorrência com o GSM?

2.4 O que acredita que mudou na empresa com a mudança do CDMA pelo GSM?

2.5 Como o seu trabalho contribuiu para esta mudança do CDMA para o GSM?

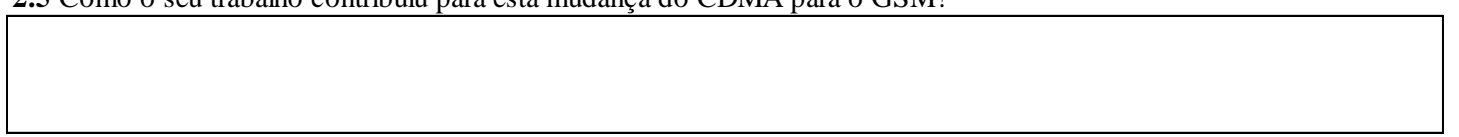

2.6 Como o seu trabalho mudou por causa desta mudança do CDMA para o GSM?

2.7 Como o resultado do seu trabalho, seja para o cliente interno como para o cliente final, apresentou mudanças de desempenho?

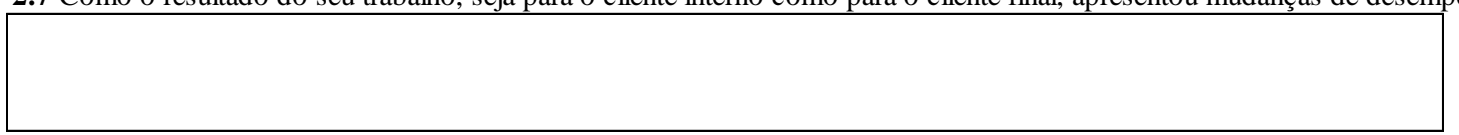

2.8 De forma geral, de que forma você acredita que a competitividade da empresa no mercado se alterou com essa mudança de tecnologia?

2.9 Como você enxerga que essa mudança de tecnologia no passado influencia a atuação da empresa nos dias de hoje? 
Parte 3: Entendimentos específicos referentes à gestão do composto de marketing

\section{a) Área de Planejamento Estratégico}

3.1a Qual era o plano estratégico da empresa à época da mudança de tecnologia?

3.2a Como se observavam oportunidades e ameaças para a empresa naquele momento?

3.3a Quais os possíveis riscos estratégicos assumidos na ocasião?

3.4a Quais as metas com as quais a empresa se comprometeu à época para este projeto? (operacionais, financeiras, de mercado, etc)

b) Área de Marketing

3.1b Como a mudança de tecnologia afetou o desenvolvimento de produtos e serviços (planos, promoções, serviços de valor agregado)?

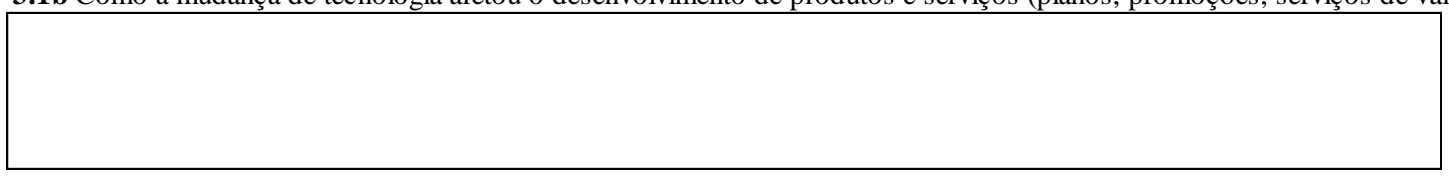

3.2b Como a mudança de tecnologia afetou a experiência do cliente com o serviço prestado?

3.3b Como a mudança de tecnologia afetou as práticas de preços da empresa (preço de planos, recarga, tarifas, aparelhos, etc)?

3.4b Como os clientes tomaram conhecimento da mudança de teconologia?

3.5b Como foi realizada a troca de tecnologia pelos clientes? Quanto tempo levou? Todos trocaram de tecnologia? 
c) Área de Inteligência de mercado e pesquisa com consumidores

3.1c Qual foi a opinião dos consumidores diante da mudança de tecnologia?

3.2c Como os clientes avaliaram a mudança de tecnologia de forma prática no seu uso?

3.3c Como os clientes avaliaram a questão do preço após a mudança de tecnologia?

3.4c Como os clientes avaliaram o processo de prestação do serviço (compra, atendimento, relacionamento) após a mudança de tecnologia?

3.5c Como a intenção de compra evoluiu junto a não-clientes após a mudança de tecnologia?

d) Comunicação e Branding

3.1d Qual o posicionamento da marca à época da mundança?

3.2d Que tipo de mudança ou evolução foi realizada no posicionamento da marca?

3.3d Por quais mudanças a marca passou por causa da mudança de tecnologia?

3.4d Como a comunicação publicitária, nos diversos meios, divulgou a mudança? 
e) Vendas e Trademarketing

3.1e Como os diversos canais de atendimento e vendas (lojas, revendas, site) se alteraram por causa da mudança de tecnologia?

3.2e Quais mudanças ocorreram na forma de atuação dos atendentes por causa da mudança de tecnologia?

3.3e Como os processos de vendas e realcionamento com o cliente mudaram nos diversos canais?

3.4e Como o portfólio de aparelhos para vendas se alterou em função da troca de tecnologia? E os preços dos aparelhos, mudaram? 


\section{ANEXO 1 - DISCURSOS INTERNOS DA PRESIDÊNCIA}

Jornal interno "Encontro Vivo" - edição de agosto/2006

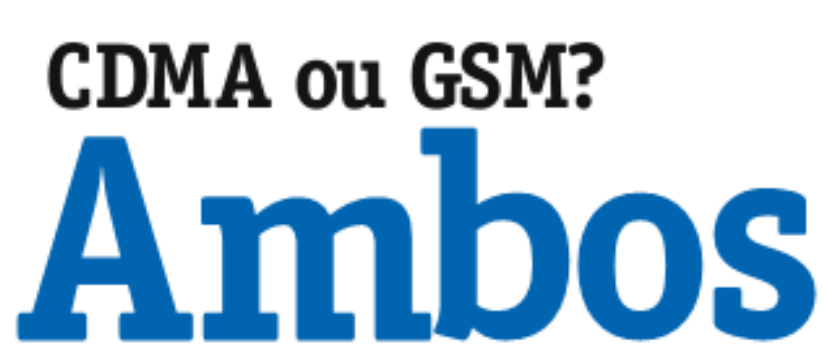

Em maior ou menor grau, a competição é uma característica dos diver sos mercados - e isso é bom, porque ela estimula a evolução das empresas, dos produtos, das tecnologias, etc., beneficiando os consumidores. No nosso setar, cam a consolidaçăo das operador as concorrentes e as estratégias agressivas na disputa pelo cliente, o termâmetro da campetição vem marcando temperaturas mais e mais elevadas. 0 s desafios são crescentes, impondo atitudes corajosas para superá-los. É isso que a Vivo está fazendo ao tomar a decisăo de implantar uma rede GSM, que coexistirá com a rede CDMA.

CDMA e GSM são as duas principais tecnologias de celular no mundo. Cam esse duplo trunfo nas măos, poderemos proporcionar ao nosso cliente um leque de produtos e serviços que nenhuma outra operadora terá condiçōes de oferecer. Um portfolio amplo, em que

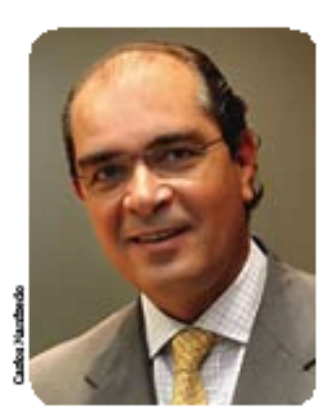
ele certamente encontrará a melhor opção, aquela que se ajustará sob medida às suas necessidades e preferéncias. Os clientes também passarăo a se beneficiar dos acordos de roaning nacional em GSM, permanecendo "ligados" nas regiōes onde ainda năo atuamos com rede própria - "ainda", Com o investimento em overlay GSM Edge, escalável a W-CDMA, a Vivo será a única operadora brasileira a oferecer aos clientes pois vamos participar das licitaçōes de novas frequiéncias da produtos e serviços nas duas tecnologias Anatel, com o objetivo de fincar as raízes da Vivo também em Minas Ger ais e estados do Nordeste onde năo estamos presentes.

Cobertura nacional é um dos objetivos que perseguimos com firmeza. Mas há outros pontos igualmente importantes. Temos investido neles. Os Projetos Estruturantes são um exemplo. Como vocé verá na página 6, concluímos o Aquarela (SAP) e o Sinapse (Data Warehouse) e progredimos em relação aos demais: $78 \%$ da base de clientes já está centralizada num único sistema de billing. 57\% nas plataformas de pré-pago e $72 \%$ no front office. Também estamos vencendo a batalha contra a clonagem. Conseguimos reduzir em $85 \%$ o numero de casos. Igualmente, temos colhido os ganhos das sinergias obtidas com a reestruturaçăo societária. No início do ano criamos a holaing e até o final de 2006 seremos, efetivamente, uma única operadora. Quanto à evohução na qualidade dos serviços, nada melhor que os indicadores da Anatel para atestála. Com $98 \%$ das metas atingidas, figuramos no topo do ranking.

Tudo isso traduz uma mesma realidade: a Vivo é uma empresa vibrante, empenhada em semear o sucesso agora e no futuro. Se os caminhos para superar os desafios nem sempre săo fáceis, a Vivo tem a clareza dos rumos a serem seguidos e coragem para fazé-lo.

Roberto Lima presidente 


\section{Quando o menos}
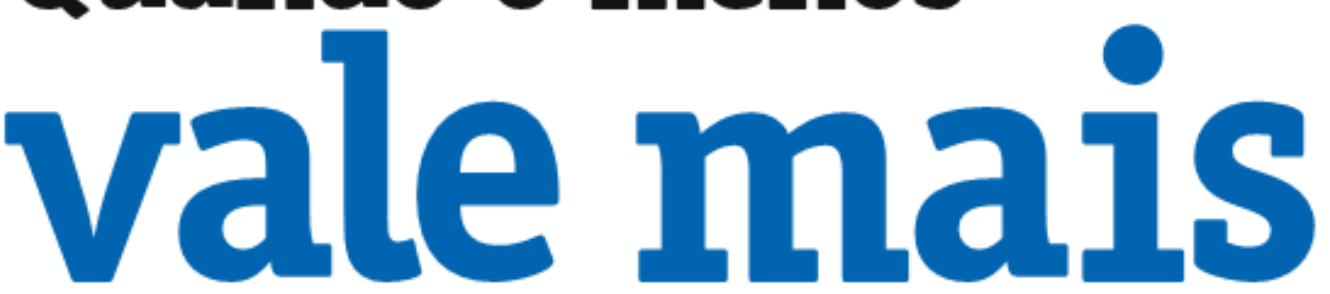

Se o jogo do mercado de comunicações móveis está cada vez mais disputado e agressivo, nós estamos em campo para vencer. Temos trabalhado arduamente para incrementar as nossas forças e eliminar as fragilidades, a fim de garantir um placar favorável para a Vivo. Queremos estar à frente em tudo - market share, receita, rentabilidade, qualidade, satisfaçăo dos clientes... -, porque um líder é vencedor em todas essas frentes.

Temos atacado várias questões urgentes, como a busca da cobertura nacional, a integraçăo de sistemas, a unificaçẵo societária, a eliminaçăo de fraudes e clonagens. Sob o guarda-chuva do "Projeto Impulso", temos times atuando em nove frentes de trabalho, com 25 projetos em desenvolvimento, entre eles o de implantaçăo da nossa rede GSM.

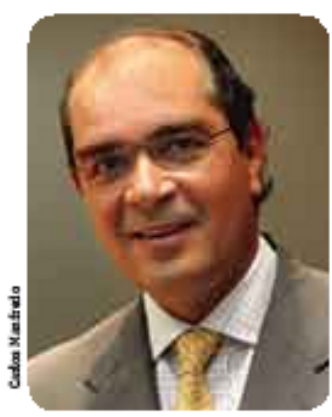

Agora, estamos nos lançando a mais um desafio: obter uma expressiva economia nas despesas operacionais deste ano, o

Fazer melhor, de maneira mais eficiente, que gerará reflexos positivos nos nossos resultados. com menores custos. Esse é o desafio que

Para isso, é in dispensável o comprometimento de todo o time Vivo. 0 que é preciso? É necessário que cada colaborador lance um olhar para o seu trabalho, para a sua área, para a empresa como um todo, e busque respostas estamos lançando aos nossos colaboradores com o objetivo de obter uma economia considerável nas despesas operacionais de para estas perguntas: "de tudo o que eu faço, o que năo 2006 em relação ao previsto no orçamento

é imprescindivel para a empresa e que posso deixar de fazer?"; "o que eu compro que năo preciso comprar?"; "posso simplificar parte do que faço?". É preciso dizer "năo" à rotina e ao "sempre fizemos assim" e disposiçăo para fazer diferente, para usar com inteligência os recursos e gerenciar de maneira eficaz as despesas. Em resumo: trata-se de fazer mais e melhor, com menos.

Por isso, pedimos a cada profissional que observe atentamente o seu dia-a-dia para identificar a melhor for ma de contribuir e colocá-la em prática - reduzindo despesas em sua área e indicando oportunidades de economia para a empresa de forma geral.

Desafios năo săo novidade para o time da Vivo, que já deu inúmeras demonstrações de sua competência, criatividade e garra. Săo os atributos dessa equipe que me dão a confiança de que vamos marcar mais esse gol no placar da Vivo. Desta vez, no campo das despesas. E, nesse, é o menos que vale mais. A empresa saberá reconhecer a contribuiçăo de cada um.

Roberto Lima presidente 
Jornal interno "Encontro Vivo" - edição de dezembro/2006 (página 1/2)

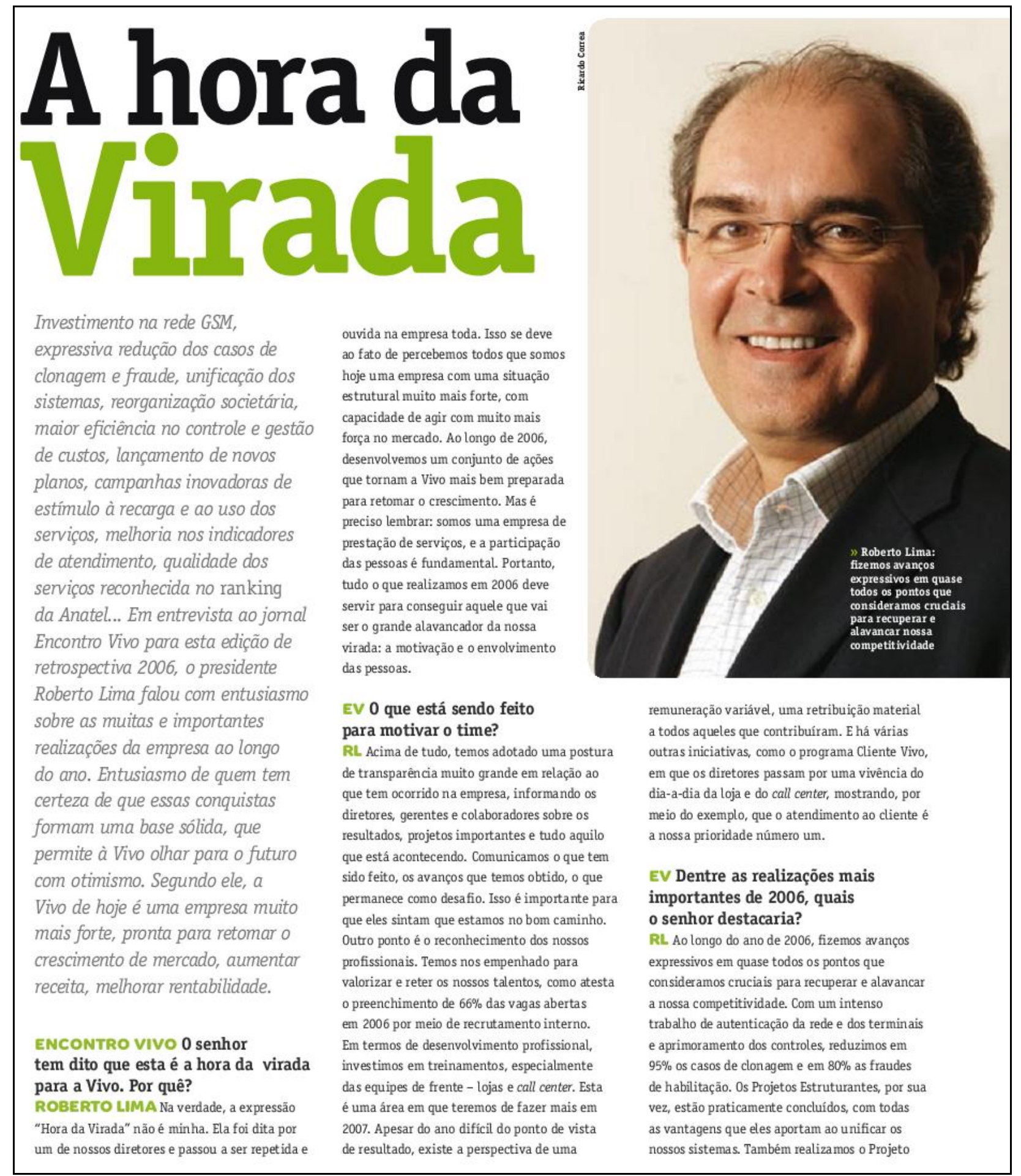


Jornal interno "Encontro Vivo" - edição de dezembro/2006 (página 2/2)

\begin{tabular}{|c|c|c|c|}
\hline$\underset{n}{\frac{\pi}{n}}$ & 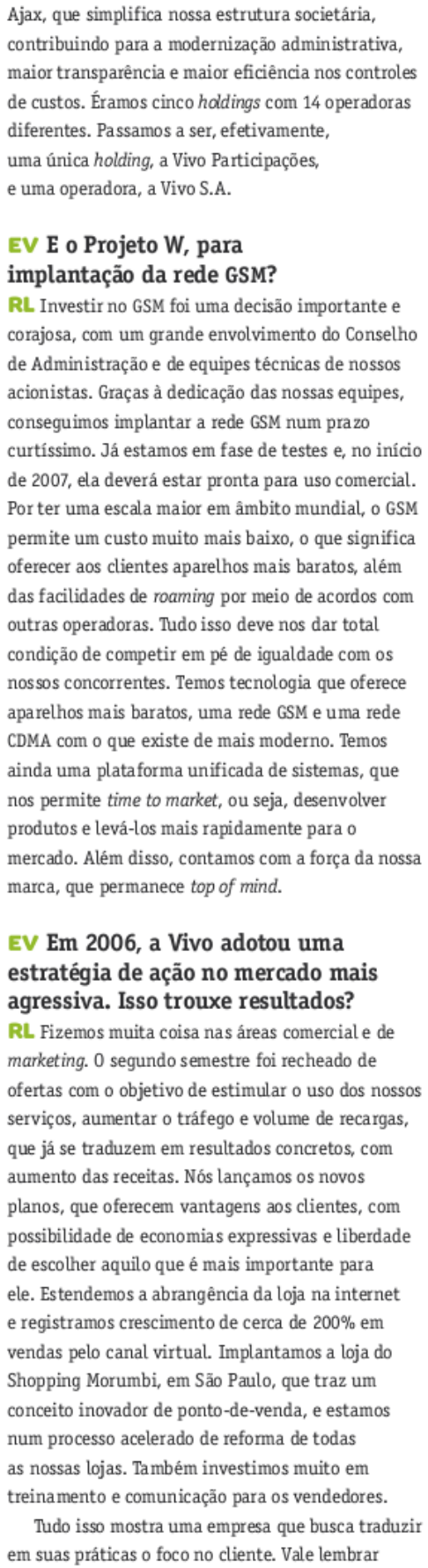 & 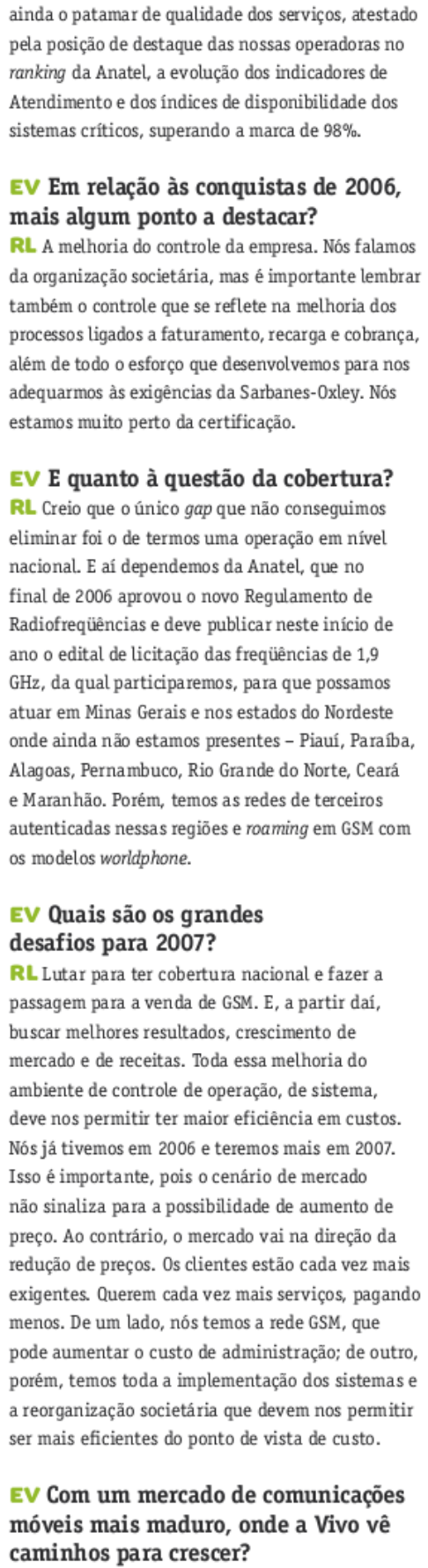 & 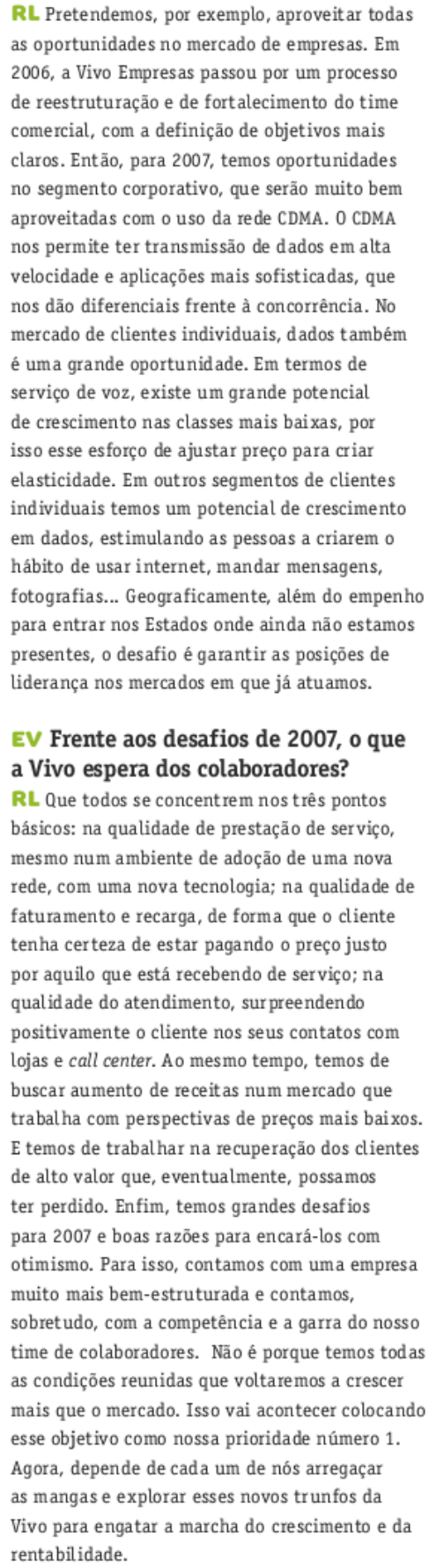 \\
\hline
\end{tabular}

